Andrews University

Digital Commons @ Andrews University

1998

\title{
A Strategy for Guiding Pastors and Congregations Through a Church-building Project in Bermuda Conference of Seventh-day Adventists
}

Carlyle C. Simmons

Andrews University

Follow this and additional works at: https://digitalcommons.andrews.edu/dmin

Part of the Practical Theology Commons

\section{Recommended Citation}

Simmons, Carlyle C., "A Strategy for Guiding Pastors and Congregations Through a Church-building Project in Bermuda Conference of Seventh-day Adventists" (1998). Professional Dissertations DMin. 614. https://dx.doi.org/10.32597/dmin/614

https://digitalcommons.andrews.edu/dmin/614

This Project Report is brought to you for free and open access by the Graduate Research at Digital Commons @ Andrews University. It has been accepted for inclusion in Professional Dissertations DMin by an authorized administrator of Digital Commons @ Andrews University. For more information, please contact repository@andrews.edu. 
ABSTRACT

A STRATEGY FOR GUIDING PASTORS AND CONGREGATIONS

THROUGH A CHURCH-BUILDING PROJECT IN BERMUDA CONFERENCE OF SEVENTH-DAY ADVENTISTS

by

Carlyle C. Simmons

Adviser: James North 


\title{
ABSTRACT OF GRADUATE STUDENT RESEARCH
}

\author{
Dissertation \\ Andrews University \\ Seventh-day Adventist Theological Seminary
}

Title: A STRATEGY FOR GUIDING PASTORS AND CONGREGATIONS THROUGH A CHURCH-BUILDING PROJECT IN BERMUDA CONFERENCE OF SEVENTH-DAY ADVENTISTS

Name of researcher: Carlyle C. Simmons

Name and degree of faculty adviser: James North, D.Min.

Date completed: April 1998

Many times pastors in their ministry face the task of leading their congregations through a church-building project. Often with little to no formal preparation for such a task, pastors and congregations experience challenges and pressures not anticipated. Sometimes the magnitude and extent of these challenges and pressures produce an adverse effect on the morale and spiritual conditions of the pastor and congregation. Since the emphasis in the Adventist Church in Bermuda is on evangelism and mission, one can expect that there will be an ongoing need for church buildings.

The development of this strategy for guiding the pastor and congregation through a 
building project has come about by documenting some of the crucial processes, pressures, and decisions from personal experiences of three church-building projects. In addition to my own experiences, other sources were utilized which allowed me to draw on the experiences and thoughts of others who have been involved in church projects.

This study is, therefore, designed to bring together in one document a complete strategy setting out guidelines and church and government policies for church-building projects in Bermuda Conference of Seventh-day Adventists. At the same time it provides an opportunity for pastors with no formal church-building preparation the opportunity to orientate themselves and their congregations should they have need to engage in a building project. With such orientation both pastors and congregations will be in a better position to anticipate the challenges and pressures that will normally take place as a result of their engagement in such a building project. It is further anticipated that this strategy will minimize potential problem areas, such as financing the project, involvement of the congregation in decision making, and constructing a building to reflect the church's theology and religious practices.

A seminar on this strategy was recently presented to a group of church members who formed a new congregation and church family. Their response is included as a part of this strategy. They indicated that they felt more prepared for establishing a new congregation and building a church home after the seminar. 


\title{
Andrews University
}

Seventh-day Adventist Theological Seminary

\section{A STRATEGY FOR GUIDING PASTORS AND CONGREGATIONS THROUGH A CHURCH-BUILDING PROJECT IN BERMUDA CONFERENCE OF SEVENTH-DAY ADVENTISTS}

\author{
A Dissertation \\ Presented in Partial Fulfillment \\ of the Requirements for the Degree \\ Doctor of Ministry
}

by

Carlyle C. Simmons

April 1998 



\title{
A STRATEGY FOR GUIDING PASTORS AND CONGREGATIONS THROUGH A CHURCH-BUILDING PROJECT IN BERMUDA CONFERENCE OF SEVENTH-DAY ADVENTISTS
}

\author{
A dissertation \\ presented in partial fulfillment \\ of the requirements for the degree \\ Doctor of Ministry
}

by

Carlyle C. Simmons

APPROVAL BY THE COMMITTEE:
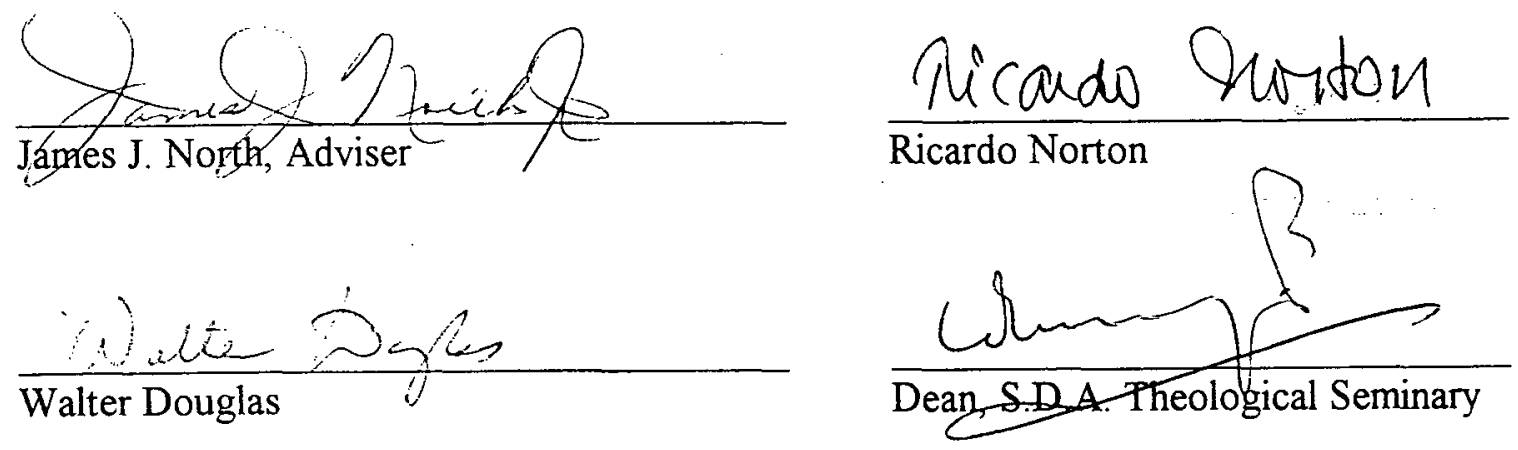

Richush. Daucitor

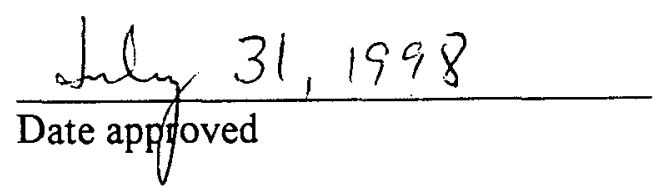


To my wife Marilyn, our sons, Julian and Michael, and daughter Marilyn-Rose 


\section{TABLE OF CONTENTS}

LIST OF ILLUSTRATIONS $\ldots \ldots \ldots \ldots \ldots \ldots \ldots \ldots \ldots \ldots \ldots \ldots \ldots$ viii

LIST OF TABLES $\quad \ldots \ldots \ldots \ldots \ldots \ldots \ldots \ldots \ldots \ldots \ldots \ldots \ldots \ldots \ldots \ldots$

ACKNOWLEDGMENTS $\quad \ldots \ldots \ldots \ldots \ldots \ldots \ldots \ldots \ldots \ldots \ldots \ldots \ldots$

INTRODUCTION $\ldots \ldots \ldots \ldots \ldots \ldots \ldots \ldots \ldots \ldots \ldots \ldots \ldots \ldots$

Chapter

I. SCOPE OF THE PROJECT $\ldots \ldots \ldots \ldots \ldots \ldots \ldots \ldots \ldots \ldots \ldots$

Statement of the Task $\ldots \ldots \ldots \ldots \ldots \ldots \ldots \ldots$

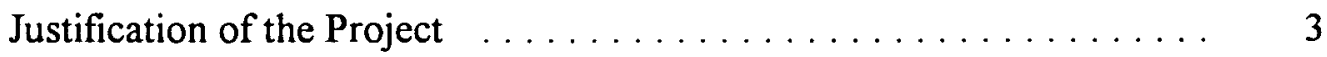

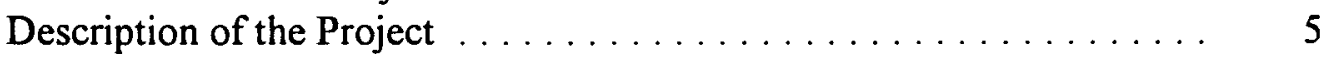

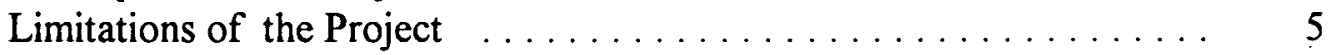

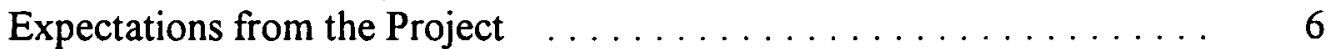

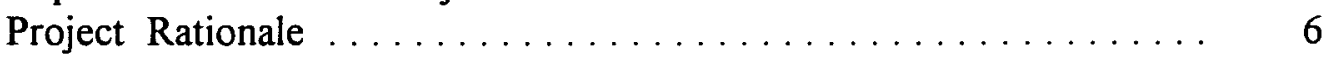

Definition of Terms $\ldots \ldots \ldots \ldots \ldots \ldots \ldots \ldots \ldots \ldots \ldots$

II. CHURCH BUILDING DESIGN AND THEOLOGY:

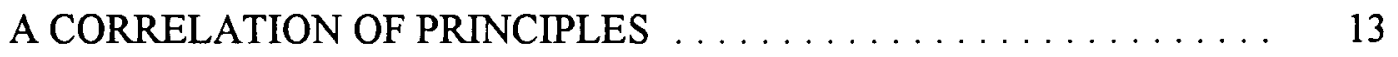

Church Architecture and Design:

How Does It Communicate? . . . . . . . . . . . . . . . . . 13

Short History of the Development of Church Building

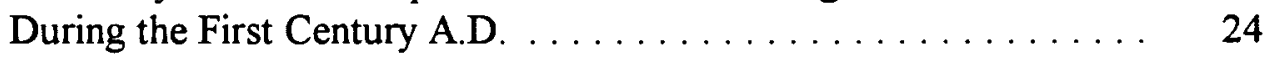

Origin and Development of Some Dominant Church

Architectural Features and Designs . . . . . . . . . . . . . 33

Influences of Church Architectural Design on Liturgy . . . . . . . . . 35

Bermudian Churches' Architecture and Design . . . . . . . . . . . . 38

Seventh-day Adventist Church Theology, Liturgy, and Architecture . . . . . . . . . . . . . . . . . . 42

Church Concepts ........................ 43

A Call to Flexibility . . . . . . . . . . . . . . . . . 46

The Concept of the Sanctuary Area . . . . . . . . . . . . . 47

The Concept of Church-Building Usage ............. 50 
The Baptistry and the Communion Table ............. 51

Musical Instruments and Choir ............... 52

The Pulpit: Its Role and Function $\ldots \ldots \ldots \ldots \ldots \ldots$

A Call to Maintain Unique Adventist Practices ............ 55

Criteria for Judging and Constructing Seventh-day

Adventist Churches in Light of Its Theology . . . . . . . . . . 56

Development of Secondary Rooms and Office Space . . . . . . . . . . 58

Church's Main Entrance/Narthex . . . . . . . . . . . . . . . 59

Classrooms for Study and Teaching . . . . . . . . . . . . 60

Fellowship Hall . . . . . . . . . . . . . . . . . . . 62

Kitchen Area .......................... 63

Acoustics and Lighting .................... 64

Administrative and Stewardship: The Office Areas . . . . . . . . 66

Adventist Church Design . . . . . . . . . . . . . . . . . . . . 67

Church Location/Site . . . . . . . . . . . . . . . . . . . . . . 68

Church Maintenance and Insurance $\ldots \ldots \ldots \ldots \ldots \ldots \ldots . \ldots \ldots$

A New Building/A New Beginning . . . . . . . . . . . . . . . . 72

III. PRESSURES, CONFLICTS, AND LEADERSHIP RESPONSES . . . . . 75

Normal Pressures of a Church-Building Project . . . . . . . . . 75

Normal Physical Pressures . . . . . . . . . . . . . . . . . . . . 75

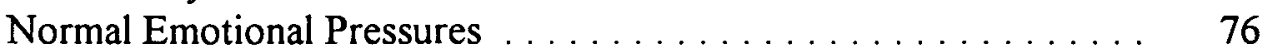

Normal Financial Pressures $\ldots \ldots \ldots \ldots \ldots \ldots \ldots . \ldots \ldots$

Building Process One $\ldots \ldots \ldots \ldots \ldots \ldots \ldots \ldots \ldots$

Advantages .......................... 78

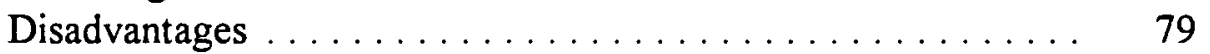

Building Process Two . . . . . . . . . . . . . . . . . 79

Advantages . . . . . . . . . . . . . . . . . . . 79

Disadvantages ......................... 80

Abnormal Pressures of a Church-Building Project . . . . . . . . . . 82

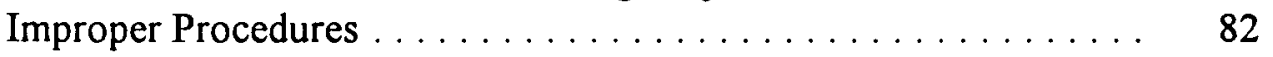

Disproportional Debt . . . . . . . . . . . . . . . . 83

Poor Interpersonal Relationships . . . . . . . . . . . . . . 85

Leadership Style Responses . . . . . . . . . . . . . . . . . . . . . 87

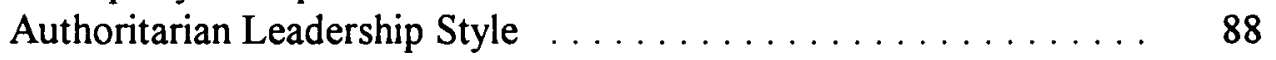

Democratic Leadership Style . . . . . . . . . . . . . . . . . . . 90

Trust . . . . . . . . . . . . . . . . . . . . . . . . . . 0 0-

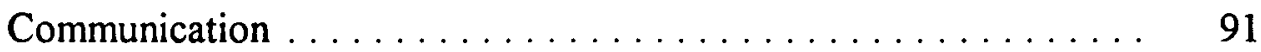

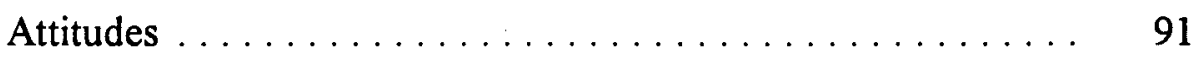

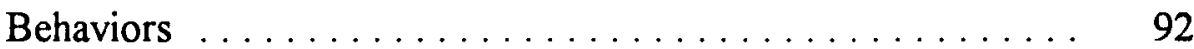

Act of Giving Praise and Recognition ................ 93

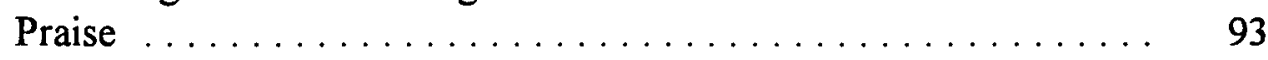

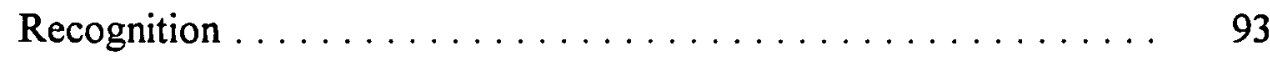




\section{POLICIES AND PROCEDURES FOR A CHURCH BUILDING}

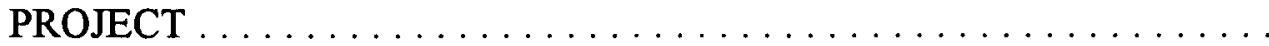

Policies Applicable to Bermuda Conference, the Atlantic Union, and North American Division of the General Conference of

Seventh-day Adventists . . . . . . . . . . . . . . . . . . . . 96

Bermuda Government Building Regulations $\ldots \ldots \ldots \ldots \ldots \ldots \quad 98$

Proposed Procedures Toward Approval

of a Church Building Project $\ldots \ldots \ldots \ldots \ldots \ldots \ldots \ldots$

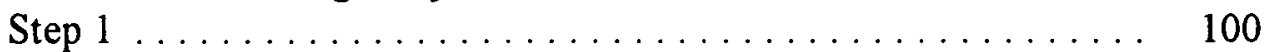

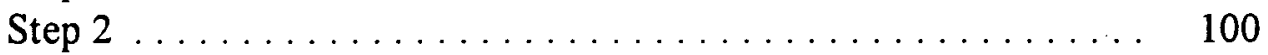

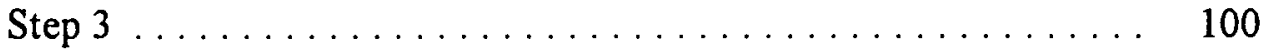

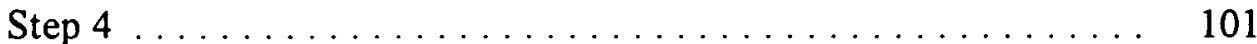

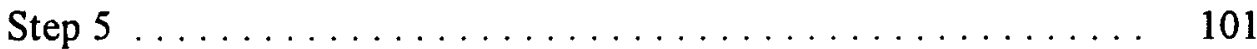

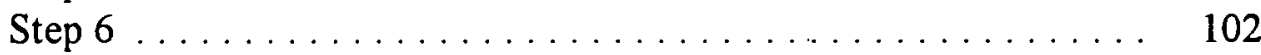

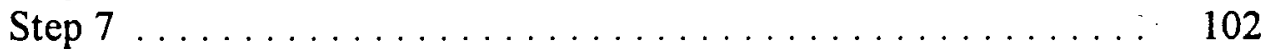

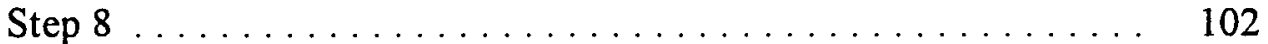

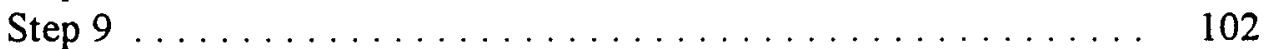

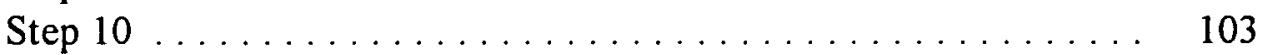

The Building Committee and Its Role ............... 104

V. FINANCING AND FUNDING A CHURCH-BUILDING PROJECT . . . . 107

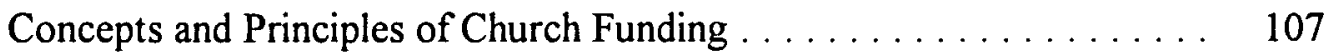

Do's and Don'ts of Fund-Raising and Funding for

Church-Building Project $\ldots \ldots \ldots \ldots \ldots \ldots \ldots \ldots \ldots \ldots$

The Finance Committee and Its Role $\ldots \ldots \ldots \ldots \ldots \ldots \ldots . \ldots 112$

Assessing the Financial Strength of the Congregation .......... 113

Assessment I . . . . . . . . . . . . . . . . . . . . . . . 113

Assessment II . . . . . . . . . . . . . . . . . . . . . . . . . . . 114

Assessment III . . . . . . . . . . . . . . . . . . . . . . . 116

Congregational Commitment to a Finished Building Project $\ldots \ldots \ldots \quad 116$

VI. CONCLUSIONS, IMPLICATIONS, RECOMMENDATIONS . . . . . . 122

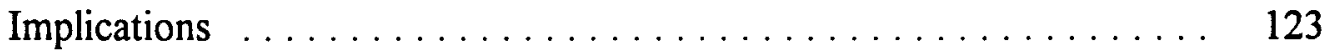

Recommendations ............................. 124

Appendix

A. CHURCH-BUILDING STRATEGY SEMINAR OUTLINE AND

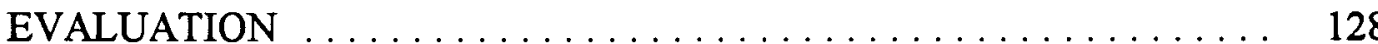

B. BUILDING A NEW CHURCH WITH A YOUNG CONGREGATION 
C. RAZING AN OLD CHURCH STRUCTURE TO THE GROUND AND BUILDING A NEW ONE $\ldots \ldots \ldots \ldots \ldots \ldots \ldots \ldots \ldots \ldots, 142$

D. CHURCH FACILITY SURVEY OF NEEDS SHEETS $\ldots \ldots \ldots \ldots \ldots$

E. PLANNING FOR CHURCH BUILDINGS $\ldots \ldots \ldots \ldots \ldots \ldots \ldots . \ldots$

F. SELECTION OF A CHURCH SITE $\ldots \ldots \ldots \ldots \ldots \ldots \ldots \ldots \ldots$

G. NORTH AMERICAN POLICY ON CHURCH BUILDINGS $\ldots \ldots \ldots .185$

H. SELECTING A BUILDING PROCESS $\ldots \ldots \ldots \ldots \ldots \ldots \ldots \ldots .188$

I. SELECTING AN ARCHITECT AND CONTRACTOR . . . . . . . . . . . 199

J. THE GARDEN OF EDEN A SANCTUARY $\ldots \ldots \ldots \ldots \ldots \ldots \ldots .211$

K. FINANCIAL WOES OF A CHURCH-BUILDING PROJECT . . . . . . . 214

L. RECIPE FOR A BETTER KITCHEN $\ldots \ldots \ldots \ldots \ldots \ldots \ldots \ldots, 231$

M. SETTING UP A PARKING LOT . . . . . . . . . . . . . . . . . . 234

N. BUILDING PERMIT/GUIDES - BERMUDA $\ldots \ldots \ldots \ldots \ldots \ldots \ldots$

O. PHOTO BERMUDA TRADITIONAL ROOF $\ldots \ldots \ldots \ldots \ldots \ldots \ldots, 248$

P. QUOTATIONS FROM ELLEN WHITE/CHURCH FUNDING . . . . . 251

Q. ADMINISTRATIVE OFFICE SPACE $\ldots \ldots \ldots \ldots \ldots \ldots \ldots \ldots, 255$

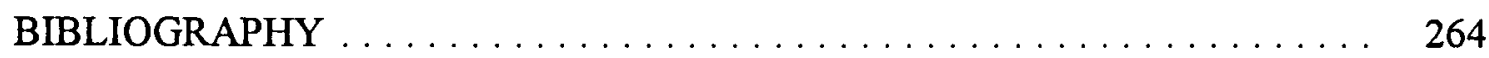

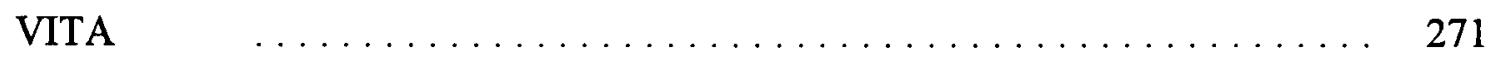


LIST OF ILLUSTRATIONS

1. Home of Wealthy Believer (c. A.D. 80) $\ldots \ldots \ldots \ldots \ldots \ldots \ldots \ldots \ldots$

2. Civic Basilica (c. A.D. 100) $\ldots \ldots \ldots \ldots \ldots \ldots \ldots \ldots \ldots \ldots \ldots \ldots \ldots$

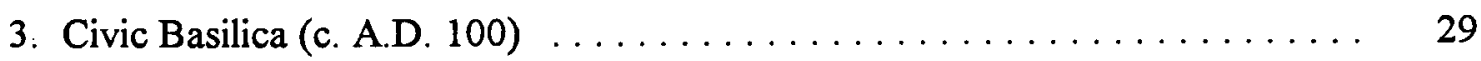

4. Basilica as Place for Christian Worship (c. A.D. 450) $\ldots \ldots \ldots \ldots \ldots \ldots$

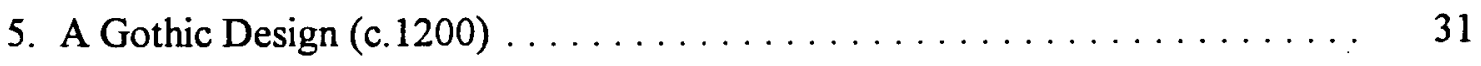

6. Typical Worship Space (c. 1925) and Reordered Worship Space ... . . . 32

viii 
LIST OF TABLES

1. Adventist World Membership and Projected Membership .......... 8

2. Two Tithing Plans Compared $\ldots \ldots \ldots \ldots \ldots \ldots \ldots \ldots \ldots \ldots \ldots \ldots \ldots$

ix 


\section{ACKNOWLEDGMENTS}

This strategy could not have been developed without the blessings and help of the Lord and the willing cooperation and support of my parental family, church families, friends, and considerate advisers. I' $m$ thankful to the Bermuda Conference and the Atlantic Union Conference administrations for making provision for the Doctor of Ministry studies in the Atlantic Union territory.

To the many secretaries who have helped me over the years, I owe a debt of gratitude. However, the biggest debt is owed to the congregations in Somerset, Midland Heights, Hamilton, and Bermuda Institute School where together we actually labored in building projects.

The experiences learned while the tasks were being undertaken will never be forgotten. To all the faithful members whose support and prayers kept these projects alive, I acknowledge that it was God's blessings that gave us success in the end. Once again, I acknowledge my late mother Ella Rose Simmons, my wife, and our children for their support and words of encouragement during my pursuit of this degree. Their understanding over the years has permitted me to spend the time required for this project without feeling I have neglected them. Their support and love will ever be remembered. To God we say, "Thank You for the opportunity of service." 


\section{INTRODUCTION}

On January 1, 1974, I was called to the ministry by the Bermuda Mission of Seventh-day Adventists. Seven months later, I was transferred to pastor the Somerset Seventh-day Adventist Church established in 1971 in the western parish of Sandys, Bermuda. At that time the Somerset congregation was using a rented facility which belonged to a Free Mason Society. Their priority was to secure their own church facility. There I was, a young pastor in ministry with a relatively new congregation of about forty members, facing the challenge of leading them through the processes of acquiring a proper church building.

Unable to find any vacant church building for sale or a building which could have been purchased and "recycled" for the purposes of a church facility in the Sandys area, the congregation decided to purchase a piece of property and construct its own church building. Until this time, I had limited building experience and practically no formal preparation for the task of leading a congregation through a building project. Although the congregation was limited in size, it had a few members who were professional masons, carpenters, and electricians. We accepted the project as a challenge and worked through the processes of designing, financing, and finally constructing a church building. Four years after we began the project, we were issued a temporary Occupancy Certificate from the Planning Department of the Bermuda Government. This permit allowed us to utilize the ground level of the building which contained the fellowship hall, Sabbath 
School classrooms, the main rest rooms, and kitchen areas. This provided us the opportunity of having an area for Divine Worship, Sabbath School classrooms, and social events. Approximately sixteen months later, we completed the upper level of the building which housed the sanctuary, the narthex, the administrative area, mother's room, and youth room.

Establishing a church in the Somerset area resulted from the Bermuda Mission's response to witnessing and church growth. With the experience of building the Somerset Church behind me and anticipating similar events in the future for the Bermuda Conference and wider church, I am encouraged to provide this strategy for my fellow pastors and their congregations who are faced with the similar challenge of constructing a church building. 


\section{CHAPTER I}

\section{SCOPE OF THE PROJECT}

\section{Statement of Task}

The task of this dissertation project was to develop a strategy for guiding pastors and congregations through a church-building project in the Bermuda Conference of Seventh-day Adventists, Bermuda.

\section{Justification of the Project}

In developing this strategy for guiding pastors and congregations through a church-building project in the Bermuda Conference, the following points of justification are presented:

Many pastors receive no formal training or orientation in their college and seminary preparation for ministry for guiding a congregation through a church-building project. As a result, the first involvement in a building project is their training. This strategy for guiding both the pastor and the congregation can be useful as a training and orientation tool before a building project commences.

There is often limited knowledge on the part of pastors and congregations regarding the local conference, union, and General Conference policies pertaining to church-building projects and fund-raising for such projects.

Many pastors and church members are uninformed as to governmental 
building regulations and codes. It is essential to work closely with qualified professionals who know the government requirements for occupancy approval.

So as to minimize confusion and misunderstanding within the congregation over a building project, it is necessary that proper procedural steps are followed, from the time the idea to build is initiated to build a church until its completion of a church structure, following procedural steps is essential.

Sometimes pastors and members of a congregation contemplating the building of a church do not fully understand the role and responsibility of the architect. As suggested above, the architect is a necessary professional who can provide the information essential for the success of the church project.

During a building project, many congregations incur financial obligations disproportional to their capacity, jeopardizing other necessary church programs, e.g., church evangelism and Sabbath School.

Many congregations and pastors, due to limited funds, enter construction and installation agreements with members and other workers within the community without proper investigation of their qualifications. This sometimes results in unsatisfactory workmanship and broken relationships.

There is often a lack of awareness as to how and why sufficient differences exist between Adventist church structures and other Christian churches and non-Christian places of worship.

Due to certain stress factors inherent in a building project, many pastors and members experience severe interpersonal conflicts and other stressful forces during a building project. Knowing what to expect in a building project can prepare a pastor and a 
congregation to manage such forces if and when they appear.

\section{Description of the Project}

In order to facilitate this task-to develop a strategy for guiding pastors and congregations through a church-building project in the Bermuda Conference of Seventhday Adventists-the following is a description of the sources of this project.

Sources which will be used include written materials on church planning, the history of church building and how building form is influenced by a denomination's theology. In addition to the above, I shall cite Seventh-day Adventist policies on churchbuilding's fund-raising, and guidelines for church planning as developed by the General Conference of Seventh-day Adventists. Brief mention will be made of the building codes and procedures adopted by the Bermuda Government and personal building experiences of myself and others will be incorporated as well.

Finally I will employ a financial tool to determine the congregation's financial ability to support a building project.

\section{Limitations of the Project}

It is not my desire to devise stock plans ${ }^{1}$ or to furnish specific designs for any church, but instead, to develop a strategy of planning and construction which can nurture a spirit of harmony among those involved.

${ }^{1} \mathrm{~A}$ set of architectural-designed plans, produced in mass quantities for public use and which can be purchased at a price usually below the regular price for architectural services. 


\section{Expectations from the Project}

It is hoped that this project will enable me to more adequately shepherd pastors and congregations in future Bermuda Conference church-building projects. It is hoped that this strategy will be useful in church-building projects of other conferences.

\section{Project Rationale}

\section{Mission and the Need for Church Buildings}

The Seventh-day Adventist Church from its beginning has taken seriously the commission of Jesus. "Go ye therefore and teach all nations, baptizing them in the name of the Father, and of the Son and of the Holy Spirit" (Matt 28:19). "And I saw another angel fly in the midst of heaven, having the everlasting gospel to preach unto them that dwell on the earth, and to every nation, and kindred, and tongue and people" (Rev 14:6).

The extent and effectiveness of the Adventist church in fulfilling the commission of Jesus can be seen in part by its growth of church membership and by the number of church buildings it owns and operates in Bermuda and around the world. Some general statistics of church structures in the world church of Seventh-day Adventists, which includes the statistics of Bermuda Conference, are as follows: by 1950 there were 5,863 church buildings in a world church membership of 756,812 . By the end of 1980 , the world church had 18,998 church buildings and a membership of 3,480,518. By the end of 1994 , the world church had 38,185 church buildings with a value of \$US3,328,676,236. The church's membership was $8,382,558 .{ }^{1}$

${ }^{1}$ General Conference of Seventh-day Adventists, Global Mission, 132nd Annual Statistical Report (Silver Springs, MD: Office of Archives and Statistics, 1994), 49. 
By the end of 1959, the Bermuda Mission of S.D.A.s had a membership of 823 with three church buildings. ${ }^{1}$ By the end of 1966, Bermuda Mission had a membership of 864 , with five church buildings. ${ }^{2}$ By the end of 1995 , after elevation from mission to conference status, the membership of Bermuda Conference was 3,038 with eight church buildings, valued at US\$14,310,248. ${ }^{3}$

Of the eight Adventist church buildings in Bermuda Conference, seven have been constructed since 1960 . These buildings were constructed largely through the financing and volunteer labor of their membership. The remaining Adventist church building in the Bermuda Conference is a "recycled" and renovated building which had served as a bakery and recreation center.

According to the book Images of Mission, produced by the Communication Department of the General Conference of Seventh-day Adventists, the Adventist Church through the end of 1993 had established work in 209 of the 236 countries recognized by the United Nations. ${ }^{4}$ Adventist missiologists' projections of membership growth beyond the year 2000 are shown in table 1.

\footnotetext{
${ }^{1}$ Bermuda Mission of Seventh-day Adventists, Business Session Report. (Hamilton, Bermuda: Bermuda Mission, 1959), 1.

${ }^{2}$ Bermuda Mission of Seventh-day Adventists, President's Report. Fifth Biennial Session of the Bermuda Mission (Hamilton, Bermuda: Bermuda Mission, 1967), 2.

${ }^{3}$ Bermuda Conference of Seventh-day Adventists, Statistical Report Year-End. (Hamilton, Bermuda: Bermuda Conference, 1995), 1.

${ }^{4}$ General Conference of SDA, Communication Department, Images of Mission. (Silver Spring, MD: Communication Department of General Conference of SDA, 1995), 18.
} 
TABLE 1

ADVENTIST WORLD MEMBERSHIP AND PROJECTED MEMBERSHIP

\begin{tabular}{cc}
\hline Year & Membership \\
\hline & Actual Membership \\
1973 & $2,390,124$ \\
1993 & $7,962,210$ \\
& \\
2000 & Projected Membership \\
2003 & 12 million \\
2013 & 14 million \\
2023 & 26 million \\
2043 & 48 million \\
& 161 million \\
\hline
\end{tabular}

Note: These projections, which employ a corresponding formula, are based on membership growth over the 20 years between 1973 and 1993 which averaged $6.2+\%$ a year. ${ }^{1}$

Ratios of Seventh-day Adventists to the world population in 1993 were 8 million SDAs to 5.506 billion people, a ratio of one to every 688 people. Projections to the year 2023 are 48 million SDAs to 8.303 billion people, a ratio of one to every 173 people. Population specialists have estimated that world population will level off at about 10.4 billion in 2090. If this holds true and if the SDA church continues to grow at its present rate, half the world population will be SDAs in about 2100. Projections to the year 2100

${ }^{1}$ Ibid., 30. 
may be 5.2 billion SDAs to 10.4 billion people. The projected ratio will be one Adventist to every two people. ${ }^{1}$

The expected growth and evangelistic emphasis of the Seventh-day Adventist Church in Bermuda and in the world church will no doubt necessitate a continual program of church development, so as to adequately minister to the needs of its members and serve the communities in which they are established.

The biblical injunction, "And let them make me a sanctuary, that I may dwell among them" (Exod 25:8), is probably the most direct commission in Scripture to construct a physical building to house the presence of God. It stands to reason that God in His love desires to dwell among His people and to provide them the privilege of gathering into His presence.

I have observed that when a congregation has its own church home, it possesses a higher level of stability, pride, and involvement in the life of its community. There is usually an increased level of cohesiveness among its membership and a willingness to invite non-SDA family and friends to its services and social activities.

Within the Seventh-day Adventist church structure, council and guidance from Ellen $\mathrm{G}$. White has been instrumental in helping to shape the focus and direction of the church's local and global mission. In addition, her counsel has influenced church leaders to establish church buildings for worship, fellowship, and ministry over the years. In 1893, Ellen White advocated that owning a church home would enhance the presence and influence of a congregation in its community or region.

${ }^{1}$ Ibid. 
In 1893, she said:

The influence of a house of worship is greatly needed, not only in Melbourne, but in our other churches. A plain, neat, commodious building, of proper dimensions, would fill their hearts with gratitude, and would give those not of our faith an opportunity to come into our assemblies and hear the words of life. There need be no costly organ, nothing for mere display; what is wanted is a house that can be dedicated to God, to which the people can come as their home, where there would be extempore preaching and prayer, and singing in which all the congregation would join, and where the surroundings would be entirely in harmony with the faith we profess. ${ }^{1}$

She further stressed that the church had difficulty in establishing itself in the hearts of the people when there was not an object of permanency in their community.

In 1899, Mrs. White advocated that churches should be established as memorials to stand in many places as a witness to the truth. In 1901 Ellen White said, "It has ever been the will of God that in all the cities of America, Seventh-day Adventists should do a widespread missionary work. Churches should be built, where every Sabbath the people may assemble to worship God and to hear the gospel."2

In the book Testimonies to Ministers, Ellen White urges:

As far as possible we are to employ the means and agencies that God has given usto introduce the truth into new localities. Churches must be built to accommodate the people of God, that they may stand as centers of light, shining amid the darkness of the world. ${ }^{3}$

${ }^{1}$ E. G. White, "The Influence of a House of Worship," General Conference Bulletin, January 27, 28, 1893, E. G. White Research Center, Andrews University, Berrien Springs, $M$.

${ }^{2}$ E. G. White, "Churches to Be Built," MS B29, 1901, Ellen G. White Research Center, Andrews University, Berrien Springs, MI.

${ }^{3}$ E. G. White, Testimonies to Ministers and Gospel Workers (Mountain View, CA: Pacific Press, 1962), 424. 
Building churches as centers of light is still very much a part of the mission and purpose of the membership in the Bermuda Conference and other parts of the world field. In his weekly newsletter, dated January 29, 1996, the President of the world church of Adventists, Elder Robert S. Folkenberg, released the most current information to date on the estimated number of churches under construction. He said:

While it is very difficult to discover how many church buildings are under construction at any one time we do know that more than 2000 churches are being completed in Africa, 65 in Cambodia, 150 in Irian Jaya, and 500 planned for China. These few projects represent about US\$19 million worth of church building projects underway around the world, many of which are done with the assistance of Maranatha Volunteers Int'l. The ratio of Seventh-day Adventists to the general population went from 1 in 846 in 1990 to 1 in 655 today. ${ }^{1}$

It is evident from current growth statistics that the Adventist church is trying to provide church homes for its growing membership.

This project, therefore, is designed to provide a strategy for guiding pastors and congregations who may find themselves faced with the need of constructing a church building..

\section{Definition of Terms}

The following terms are defined in order to clarify their usage in this study:

Stock Plans. A set of architectural designed plans, produced in mass quantities for public use and which can be purchased as a price usually below the regular price for architectural services.

Liturgy. Acts and works of people in praise and worship.

${ }^{1}$ Robert S. Folkenberg, Newsletter from the G. C. President, January 29, 1996, 1. 
Church-Look. Term associated with architectural appearance of cathedrals or churches whose design is influenced from medieval times.

Narthex. An area usually located after the entrance through the main doors of the church, but prior to entry into the sanctuary area itself.

Normal Pressures. Varying degrees of stress and/or anxiety due to specific demands on one's time, energy and money.

Disproportional Debt. Financial indebtedness that is beyond the ability of the debtor to pay.

Improper Procedures. Decisions made outside of the proper line or sequence of authority.

Worship Atmosphere. Involving environment.

Emotive Factors. Aesthetic and beauty factors of worship area. 
CHAPTER II

\section{CHURCH BUILDING DESIGN AND THEOLOGY:}

\section{A CORRELATION OF PRINCIPLES}

\section{Church Architecture and Design: How Does It Communicate?}

When you look at a church building, what type of message do you receive? Can church architecture speak? Should a pastor and congregation be concerned that their building design reflect their theology and their mission? The following statements and explanations are from some theologians, writers, and church leaders, who convey their perspectives on how extensively church architecture communicates.

In an article entitled "Symbolism at Work: The Gospel According to Architecture," Tom Schwanda raised the following question: "Do buildings talk to you? They do to many! . . The truth is out: buildings do talk and if people listen, they can learn."1

Schwanda referred to Jesus' comment that seems to reinforce Schwanda's claims that buildings speak. He notes that Jesus at His triumphal entry said, "I tell you, if these were silent (the people cheering His entrance), the very stones would cry out" (Luke 19:40 RSV; cf. Hab 2:11; Josh 24:27). "And what do the stones of a church building

${ }^{1}$ Tom Schwanda, "Symbolism At Work: The Gospel According to Architecture," Reformed Review 31 (Spring 1978): 134. 
say?" Schwanda continues, “We are always concerned and critical, guarding our sermons that they may accurately speak God's Word. But how much effort is channeled to design our structures to verify this same gospel? Unfortunately, the answer is rather discouraging, especially as we view our own heritage."1

It appears that Schwanda recognized inherent communicative powers in church design and architecture. He therefore appeals for pastors and congregations to recognize that stones can speak. His claims find support in light of the current trend of many in our society to communicate through visual patterns.

Schwanda cites Lyle Schaller as observing that our societal pattern is moving from the verbal emphasis of previous generations to a more visual stance. This is a significant change in our society. Schaller writes: "The reading intake of people has dropped as more individuals receive their information from media resources. The point is this, if Johnny cannot read or write, he can at least look."

The implication of Schaller's assertion is that Johnny will have the ability to learn through the process of observing. The claims that a church building's design and materials have the capacity to transmit messages are supported further by architects, artists, theologians, and church planners. For example, Nancy M. Tischler, Professor of Humanities and Literature, Capital Campus of Pennsylvania State University, says:

Every building communicates something about its use, its builder, and its age. Did you ever stop to think what your church building says to the

${ }^{1}$ Ibid., 134-5.

${ }^{2}$ Lyle Schaller, cited in Schwanda, 135. 
world about you and about your faith? ${ }^{1}$

She continues by saying, "The manner in which a people choose to house their

gods can symbolize the religion, their concept of the god, their worship service, the nature of the people, and their relationship with other cultures." She cites as an example:

The tabernacle- - a tent with carefully prescribed partitions and environs and floor plans-is a striking image of a Nomadic people, of the God who spoke to them through their leader, Moses, of their obedience to the very letter of the law. It was set in the midst of the people to remind them that God himself dwelt in their midst. It housed the Ark of the Tabernacle, a reminder of God's Law and his voice speaking unequivocally to his chosen people. Its adornments were their tribute to his glory. Its Holy of Holies was a symbol of his 'otherness.' Its laver and altar and table were reminders of their ritual. The symbols were all far more complex than this would suggest, but this outline provides a useful pattern for analysis. ${ }^{2}$

Dr. Richard Davidson of Andrews University Theological Seminary suggests that

there are hints throughout scripture that the heavenly sanctuary may have had a

counterpart on earth even before the mosaic tabernacle. He says:

The language of Genesis 1-2 points towards the garden of Eden as the earthly counterpart of the heavenly sanctuary! As we compare the portrayal of Eden with the descriptions of later divine instructions for the building of God's sanctuary/temple by Moses and Solomon, surprising insights begin to emerge. ${ }^{3}$

Davidson argues:

On earth after creation there were three spheres of space, in ascending degrees of holiness ("set apartness for special use"): the earth, the garden, and the "midst of the garden." These three spheres are seen again at

'Nancy M. Tischler, "Sticks and Stones," Christianity Today, June 7, 1974, 19.

${ }^{2}$ Ibid., 19.

${ }^{3}$ Richard M. Davidson, The Garden of Eden a Sanctuary, Andrews University Theological Seminary, Berrien Springs, MI, paper presented to NAD Presidential Retreat, California, 1996. 
Sinai; in the camp, the place where the seventy elders could go on the mountain, and the immediate presence of god where only Moses could go they are repeated in the court, the Holy Place, and the Most Holy Place in the Sanctuary. ${ }^{1}$ (See Appendix J for further reading.)

\section{Dr. Raymond Holmes says:}

That under the old covenant the people did not have the privilege of entering the Holy Place or the Most Holy Place in the tabernacle or temple. However, under the New Covenant believers have free access to the Father because Jesus has opened the way. He says, "Jesus has literally opened the way into the heavenly sanctuary for us. In worship, and by faith, we enter the heavenly sanctuary freely and without hindrance."

In view of the above theological contentions, we may possibly see early beginnings for the basic formation of worship areas. This architectural pattern in which church building have an entrance or narthex, sanctuary and pulpit areas follows the model of the garden of Eden and the sanctuary/temple structure, outer area, holy, most holy place..

Richard A. Smits, senior studio architect with Skidmore Owings and Merrill,

Chicago, Illinois, commenting on the function of church structure states:

The purpose and duty of a church is to preach the full Gospel, purely and powerfully, and to minister to the needs of its people. But a congregation should also realize that the architecture of its building or buildings is a matter of Gospel. ... The architecture of the church is neither irrelevant nor unimportant; it is a matter of Gospel. The building that a church occupies and the furnishings within it either reinforce or contradict what the church preaches. ${ }^{3}$

${ }^{1}$ Ibid., 49.

${ }^{2}$ Dr. Raymond C. Holmes, Sing a New Song (Berrien Springs, MI: Andrews University Press, 1984), 49.

${ }^{3}$ Richard A. Smits, "The Gospel and Architecture," Christianity Today, April 23, 1976, 20. 
Smits cited that God was the architect for the tabernacle of the Israelites (Exod 35-39). Moreover, architecture is not to be ignored or left to the elite and artistically sensitive. But rather all Christians should strive to live aesthetically as well as theologically obedient lives as part of their service to God. ${ }^{1}$

According to Ezra Earl Jones, a scholar-bureaucrat employed by the United Methodists, noted for his sociological studies on developing new churches and for enabling faltering old ones either to find new life or to die with dignity. "A church's image in the community can be its most important asset or liability. Many factors contribute to that image, but the most tangible one is the building, which often determines a newcomer's first impression of the congregation."”

Jean Caffey Lyles commenting on workshop leader Robert Rambusch, a Roman Catholic artist-designer, says, "Rambusch believes that the architect must function as a teacher of theology ... and that the architect task is to make a theological statement."

Robert E. Webber, Professor of Theology at Wheaton College, Wheaton, Illinois, observes:

Church architecture throughout the ages has been a sign and a symbol of the presence of God in the world, reflecting in its diversity the various aspects of human interpretation of that presence. The great upward sweep of the Gothic arch as well as Byzantine icons of Jesus, Mary, the disciples, the prophets, and the saints both shadow and illuminate the heavenly realities that give meaning and purpose to our life. This suggests

\section{${ }^{1}$ Ibid., 19.}

${ }^{2}$ Jean Caffey Lyles, "Friendly Spaces, Ecclesiology and the Architect: National Interfaith Conference on Religion and Architecture, "Christian Century September 21, 1997, 807.

${ }^{3}$ Ibid., 808. 
a profound truth: the use of space ought to be harmonized with our pattern of God-oriented worship and become its servant. ${ }^{1}$

Webber is of the opinion that a congregation must face the implications of its choices. He questions:

How does a building capture the tension between the awe and mystery, the transcendent God as well as express the warmth of an intimate and personal incarnation? Is transcendence only demonstrated in high ceilings, stained glass, and stark, wooden pews? Can lighting, the use of color, cushions, and carpeting be thoughtfully brought together to express the relationship between awe and intimacy? ${ }^{2}$

Responding to Webber's questions, one may suggest that God's transcendency and intimacy can be practically merged through architecture in the following ways. By lowering the sanctuary ceiling height to around eighteen to twenty feet. Carpeting the floor, cushioning the pews and arranging them in a semi-circular formation. Beginning the first row of pews approximately seven to ten feet from the centrally located pulpit. Having adequate lighting, a balanced color scheme for carpet and the walls, and finally a single chancel from which both minister and choir face the congregation in worship. This is a departure from most furniture placements and types of ministries conducted in churches influenced by medieval architecture, in which they have a divided chancel, pulpit located to the side and a great distance from the congregation. The ministers usually face the communion table with their backs to the congregation and the ceiling of most medieval architecture is most high emphasizing God's transcendency. Intimacy and

${ }^{1}$ Robert E. Webber, "Church Buildings Shapes of Worship," Christianity Today, August 7, 1981, 19.

${ }^{2} \mathrm{Ibid}$. 
closeness in worship can create a sense of nearness in the encounter with God and ones fellow worshippers.

Webber continued his argument by saying, "The goal of church architecture is to incarnate the meaning of worship and space and to demonstrate through space the ultimate transformation of creation. In this way, space proclaims the redemption and ultimate transfiguration of creation."

It seems that Webber is implying that church architecture can generate purpose and meaning to worship. This relationship between the purpose and use of space can help us to understand to some degree the process of transformation. Perhaps one may see this process as a parallel to the new birth experience, 1 Cor 5:17. The conversion from one form to another in any case involves a new birth of that creation. Donald $\mathrm{H}$. Speck seems to embrace Webber's theological sentiment with reference to transformation of space: "Church buildings should be built for God, for His use, but they should also be built for us and our mission."2

In creating church buildings for God's use and our mission,, Seventh-day Adventists have tended to build churches not on the grand scale of the medieval cathedrals. The emphasis has been on function instead of architectural greatness as counseled by Ellen White.

By building churches on a modest scale as compared with the grand cathedrals, the Adventist congregation has had an opportunity to articulate to a key doctrine of the

\section{${ }^{1}$ Ibid.}

${ }^{2}$ Donald H. Speck, cited in Ed Streeter, Syllabus for CHMS528 Architecture for Clergy, Andrews University, Berrien Springs, MI, 1980, 2. 
church, that of the imminent return of Jesus. Churches built on a smaller scales usually provide for smaller size congregations thereby allowing for more personal interaction of the membership and less expenditure of funds for construction and maintenance. Coupled with the preaching of the imminent return of Christ, warm intimate church structures can denote a sense of economy and urgency.

Arguing the points of proclamation and communication of church architecture, Edward A. Sovik, noted for over a dozen state and national design awards, addressed the issue of expressive elements in church architecture in this way:

To the congregation that sets out on a building project certain questions arise or should arise that relate to the expressive character of architecture. ... The whole tradition of church building, one may assert, has been directed toward making buildings which are vigorous and explicit witness to the presence of the faith in our communities. ${ }^{1}$

Sovik suggests that the reason why traditional churches have chosen prominent sites in our communities is so that they can be a means of witness to the faith of Jesus Christ and at the same time show separation from secular buildings around them. ${ }^{2}$

Robert Carr, commenting on Reverend Lynn's statement, says that Lynn advocates that people and buildings are inevitably related and that religious structures reflect religious values, and religious attitudes are shaped by the environment. ${ }^{3}$

Ellen G. White, expressing her sentiments on the communicative powers of 1973), 50.

${ }^{1}$ Edward A. Sovik, Architecture for Worship (Minneapolis: Augsburg Publishing,

${ }^{2}$ Ibid., 51.

${ }^{3}$ Robert Carr, "The Archi-Liturgical Movement and The Seventh-day Adventist Church" (Master's Thesis, Michigan State University, 1975), 19, Adventist Heritage Center, James White Library, Andrews University, Berrien Springs, Michigan. 
church buildings, declares, "I wish our buildings to represent the perfection God requires of His people." She further contends that it is not the largeness or the grandeur of an edifice that impresses hearts, but the people, by their principles of righteousness, justice, equity, and Christ-like spirit that will witness equally with the institution. ${ }^{2}$

From Mrs. White's statement, we may conclude that a neat, well designed and quality structured church-building can jointly witness to God's character as may the lives and Christian practices of its members. In recognition of these two communicative powers, Mrs. White challenges church members to impact their community by blending their personal Christian behaviour with the witness of a quality, well-kept and attractive church-building.

Before closing this section I want to present two additional positions related to church architecture as advocated by Richard Smits and Edward Sovik on the subjects of building materials and architectural authenticity respectively. In my opinion, these positions, while they may not be considered as the only standard for church structures, they challenge us with what can be considered the ideals in church architecture with reference to building materials and architectural authenticity or in general the use of genuine things versus imitation materials. See arguments ahead.

We must keep in mind that these ideal conditions may not always be available or affordable by every congregation, however Smits' and Sovik's views coupled with the example of the tabernacle in the wilderness, Exod 25-28, and Solomon's temple, $1 \mathrm{Kgs} 5$ -

${ }^{1}$ E. G. White, Evangelism (Washington, DC: Review and Herald, 1946), 378.

${ }^{2} E$. G. White, "Lessons from the Life of Solomon," Review and Herald, 4 January 1906, 7, quoted in Carr, 11. 
7 , can serve as an example of the types of materials and the quality of workmanship employed when the sanctuary and the temple were constructed.

Smits says:

It is the total building design, however, where the greatest contradiction occurs. We can't believably contend that Christianity is for contemporary man from behind the false fronts of imitated historical styles. We can't preach the genuineness of the Christian life from within buildings that display imitation stone, imitation stained glass, imitation wood, and imitation plants. Nor can we profess our concern for the plight of the world from interiors whose emphasis is on comfort or luxury. Our building must stand as a critique of the values of our age or the impact of what we preach will be diminished. ${ }^{1}$

Smits seems to suggest that there can be a conflict in the presentation of

Christianity by the types of materials employed in a church structure. It is obvious from his statement that he views building material as having inherent powers to communicate through symbolism and representation. He is not alone in his position. Addressing the issue of architectural authenticity, Sovik observes that our civilization is so abundantly supplied with substitutes, artifices, artificialities, and the ersatz that the search for the genuine thing is sometimes long and expensive. ${ }^{2}$

He adds:

Consider if the structure is concrete, the architect will not seek to pretend otherwise. If it is steel, the shapes will logically follow the logic of steel fabrication. ... If it is wood, the detailing of the wood will not imitate the kind of wood structure that our forefathers used. There will be no architectural cosmetics that aim to deceive, like plaster painted to look like stone, veneered on plywood surfaces that pretend to be solid boards, plastic flooring that imitates slate or clay tile, machine-worked steel that imitates iron, no electric candles, plastic philodendrons, artificial leather,

${ }^{1}$ Smits, 21.

${ }^{2}$ Sovik, 56. 
wood grained laminates, or wood artificially 'dressed' to look old and worm eaten, etc. ... If we surround ourselves with environments of clever artifice, we cannot avoid being affected by them. We ourselves become artificial and our capacity to live lives of authenticity is diminished. ${ }^{1}$

Beyond the use of building materials employed in a church project, the matter of using artificial plants and flowers in the decoration of the sanctuary area sometimes arises. Using the module of the sanctuary and temple in the Old Testament times, and more forcefully the theological arguments of the "Garden of Eden a Sanctuary," by Dr. Richard Davidson (see Appendix J), the employment of genuine articles in worship areas seems evident and standard. According to Dr. Davidson's arguments, that the garden of Eden, provided a place for man to encounter God in worship and communication. This garden encounter automatically compels us to visualize an environment of beautiful plants and flowers of all different colors, shapes, and smells. Adam's task to dress the garden, serves as a module to those minister in worship today. Likewise, the use of natural plants and flowers, should be the first goal for our employment in worship areas as well. We must guard against offering to God less than the very best we can, rather we must follow the Biblical examples as our ultimate standard.

Ellen White encouraged the Adventist church to realize the potential communicative powers that church structure has. She spoke about humble houses of worship standing as a sign and memorial of God's Sabbath. The memorials were to stand as witness to the truth. ${ }^{2}$

${ }^{1}$ Ibid., 57.

${ }^{2}$ Ellen G. White, Gospel Workers (Washington, DC: Review and Herald, 1915), 431. 
Reinforcing the call of Mrs. White for buildings that will witness for truth, Donald Bruggink and Carl Droppers submit:

Architectural solutions portrayed in glass, concrete, and steel proclaim a message that either illuminates the Word of God or is in direct opposition to it. If the gospel of Christ is worthy of accurate verbal presentation week by week, it is also worthy of faithful architectural proclamation when its message speaks from year to year. ${ }^{1}$

\section{Short Histery of the Development of Church Building During the First Century A.D.}

Among the many histories written about the development of church buildings, two contributors used in this project are Nancy M. Tischler, professor of Humanities and Literature, Capital Campus of Pennsylvania State University, Middletown, 1974, and Ralph R. Van Loon, coordinator for Church Architecture Division for Parish Services of the Lutheran Church in America.

In her article entitled "Sticks and Stones," Professor Tischler stated that early Christians, seemingly first-century Christians, were intensely sensitive to the implications of architecture. Their conflicts with pagan forces left them antagonistic to temple structures associated with pagan power and brutality. ${ }^{2}$ She writes:

The earliest Christians apparently met in the open, in public places, in homes, and in hidden rooms. Without power or affluence, they met where they could to sing, to pray, to hear the Word of God, to baptize their young, to mourn their dead, and to share in love feasts. ${ }^{3}$

${ }^{1}$ Donald Bruggink and Carl Droppers, Christ and Architecture (Grand Rapids, Michigan: William B. Eerdmans Publishing Company, 1965), 1, quoted in Carr, 5.

${ }^{2}$ Tischler, 19.

${ }^{3}$ Ibid. 
Ralph R. Van Loon in his article entitled "The Church Building" says:

At first, the early Christians used the more spacious homes of the wealthy believers as places of worship. Their homes required little alterations for the use of certain practices in Christian worship. The courtyard (the atrium) usually included a pool to catch rainwater, convenient for the celebration of Holy Baptism. The family table served as the altar, holding their communion bread and wine. In some instances, homes were remodeled to provide an enlarged room for the worshipping assembly, a baptistry, classrooms for learners, and working space for the clergy. ${ }^{1}$

In some communities, Christians used the civic basilica, a building used as a court house and also a public market. ${ }^{2}$ (See figure 1.)

Although the early Christian church faced periods of persecution, members dared to evangelize, to teach, and to assemble for worship. They even dared to build churches modeling the basilica style to accommodate the growth of their membership. (See figure 2.). Their persecutors, however, would usually destroy or appropriate these buildings for their own use. ${ }^{3}$

To many Christians, burial places of the martyrs became special holy places. Van Loon states, "The tombs of martyrs became altars for the bread and wine where the Holy Communion were placed over the relics of the martyred, establishing the awareness that Christ was present most unusually in such a place. ${ }^{4}$

In A.D. 313, under Emperor Constantine, official persecution against Christians

${ }^{1}$ Ralph R. Van Loon, "The Church Building," in Space for Worship (Philadelphia, PA: Lutheran Church Publishers, 1975), 7.

${ }^{2}$ Tbid.

${ }^{3}$ Ibid.

${ }^{4}$ Ibid. 


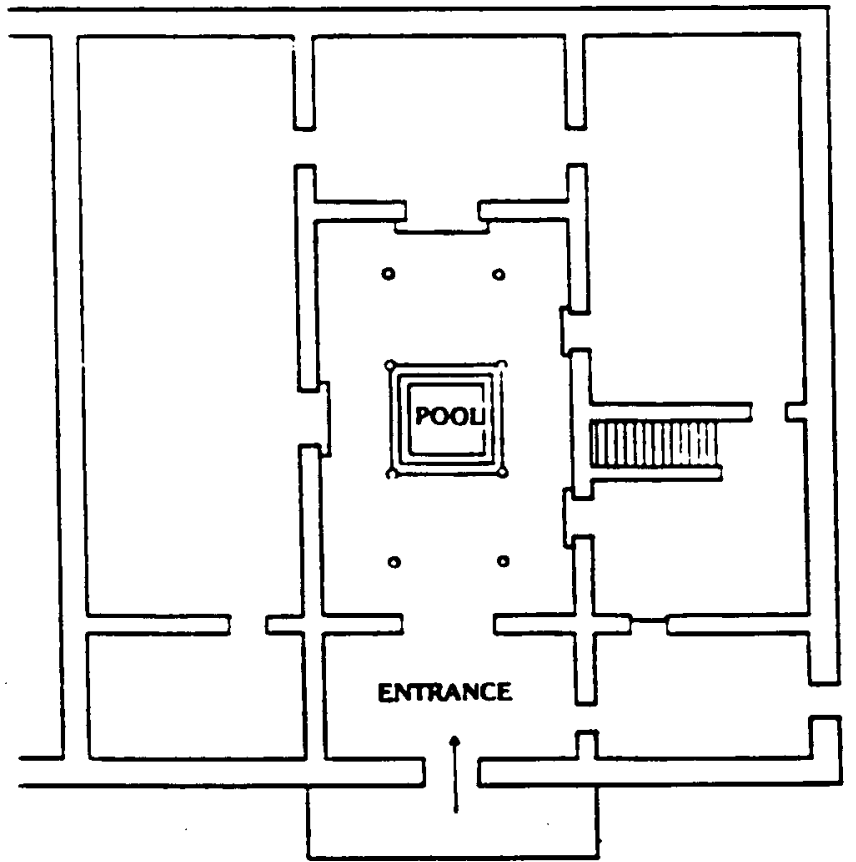

Figure 1. Home of wealthy believer (c. A.D. 80). Source: Ralph R. Van Loon, "The Church Building," in Space for Worship (Philadelphia: Lutheran Church Publishers, 1975), 6. Reprinted with permission. 


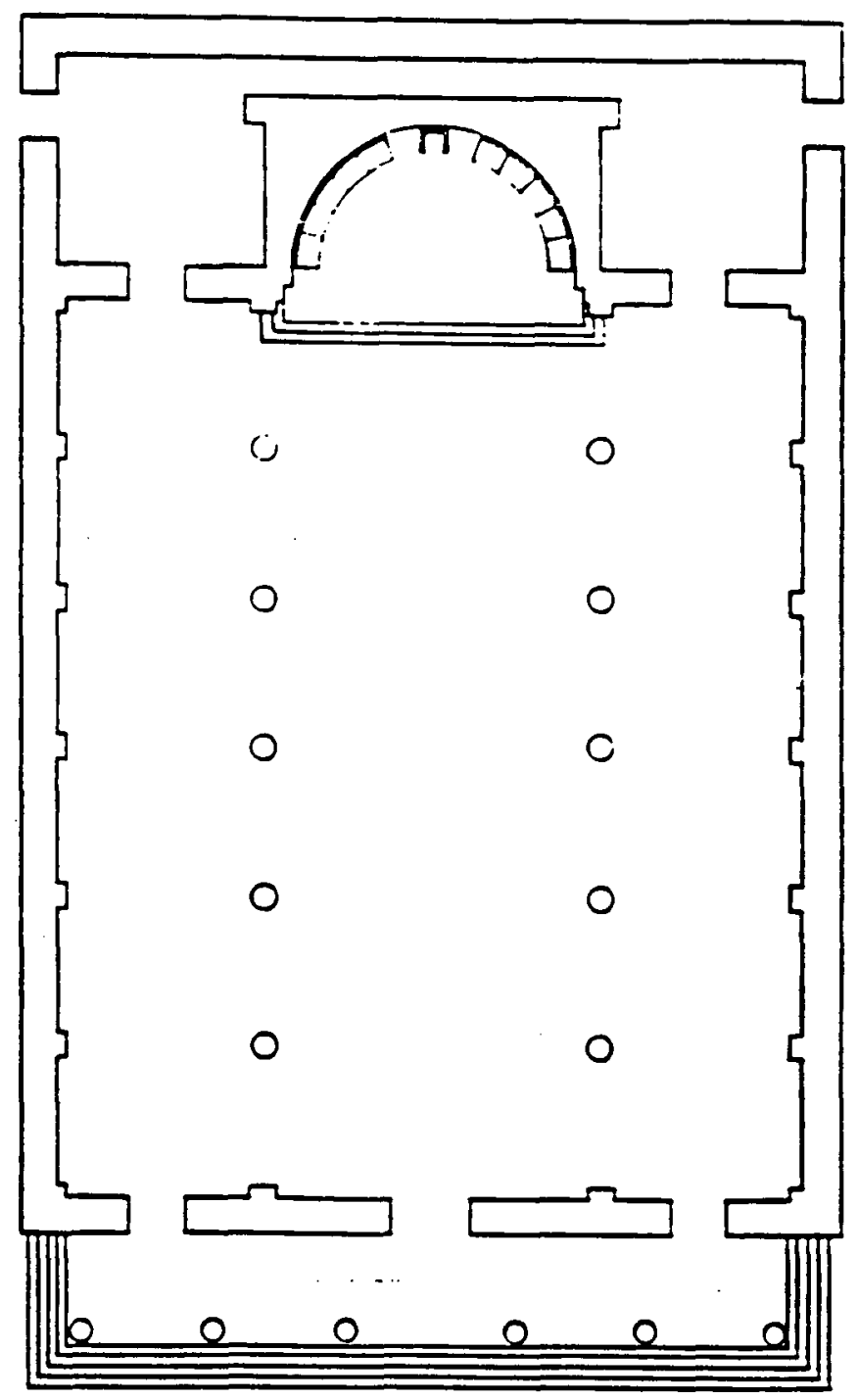

Figure 2. Civic basilica (c. A.D. 100).

Source: Ralph R. Van Loon, "The Church Building," In Space for Worship (Philadelphia: Lutheran Church Publishers, 1975), 6. Reprinted with permission. 
was ended. Constantine, wanting to show favor and repatriation, financed from government funds new church buildings and renovated damaged ones. These basilicalike rectangular-shaped structures were long and spacious. They were inspired by the Greek temple models. They were used for religious services as well as other functions, such as courts of law and public market places (see figures 3 and 4).

As time progressed, the influence of the court procedures dominated the use of the space in these basilicas. Van Loon points out that the judge's throne in the apse of the basilica became the bishop's throne, and the remaining space on the platform reserved for law clerks now was reserved for other orders of clergy. The congregation gathered in the public space signaling a trend toward a spectator role for lay persons. ${ }^{1}$ (See figure 5.)

By the fourth century A.D., the basilica type building had been modified to accommodate a liturgy that had become a clergy speciality. ${ }^{2}$ (See figure 6.)

By the sixteenth century, after the Reformation, many people seemed unwilling to change the liturgical functions and furniture placement in their churches. Church buildings continued to be designed and constructed as though the Reformation never happened. Medieval concepts of worship and church architecture continued to exist and were still held even some centuries later. However, today large numbers of churches are discovering that architecture design must serve the needs of the worshipers rather than

${ }^{1}$ Ibid., 8.

${ }^{2} \mathrm{Ibid}$. 


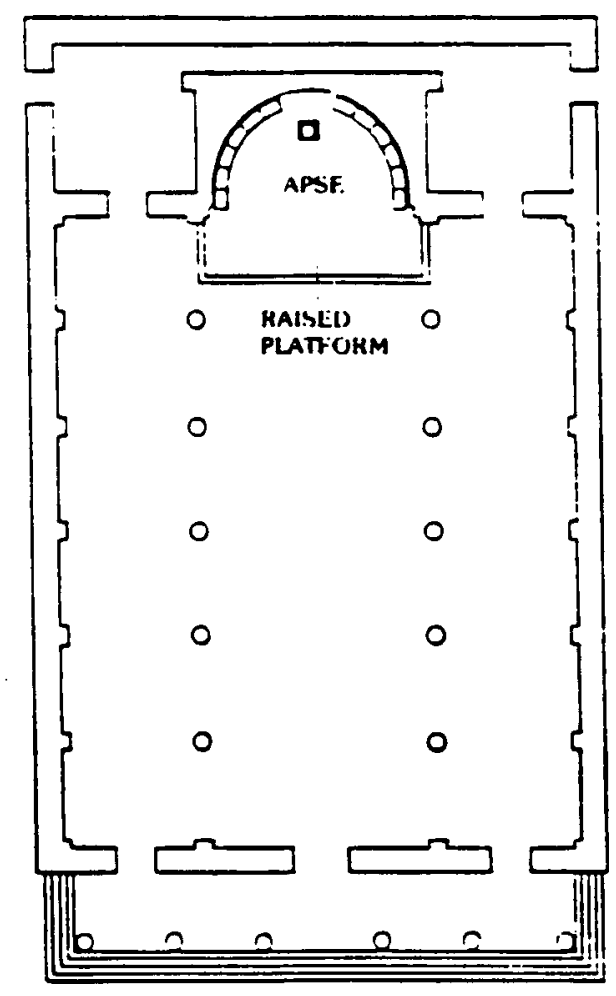

Figure 3. Civic basilica (c. A.D. 100).

Source: Ralph R. Van Loon, "The Church Building," In Space for Worship (Philadelphia: Lutheran Church Publishers, 1975), 6. Reprinted with permission. 


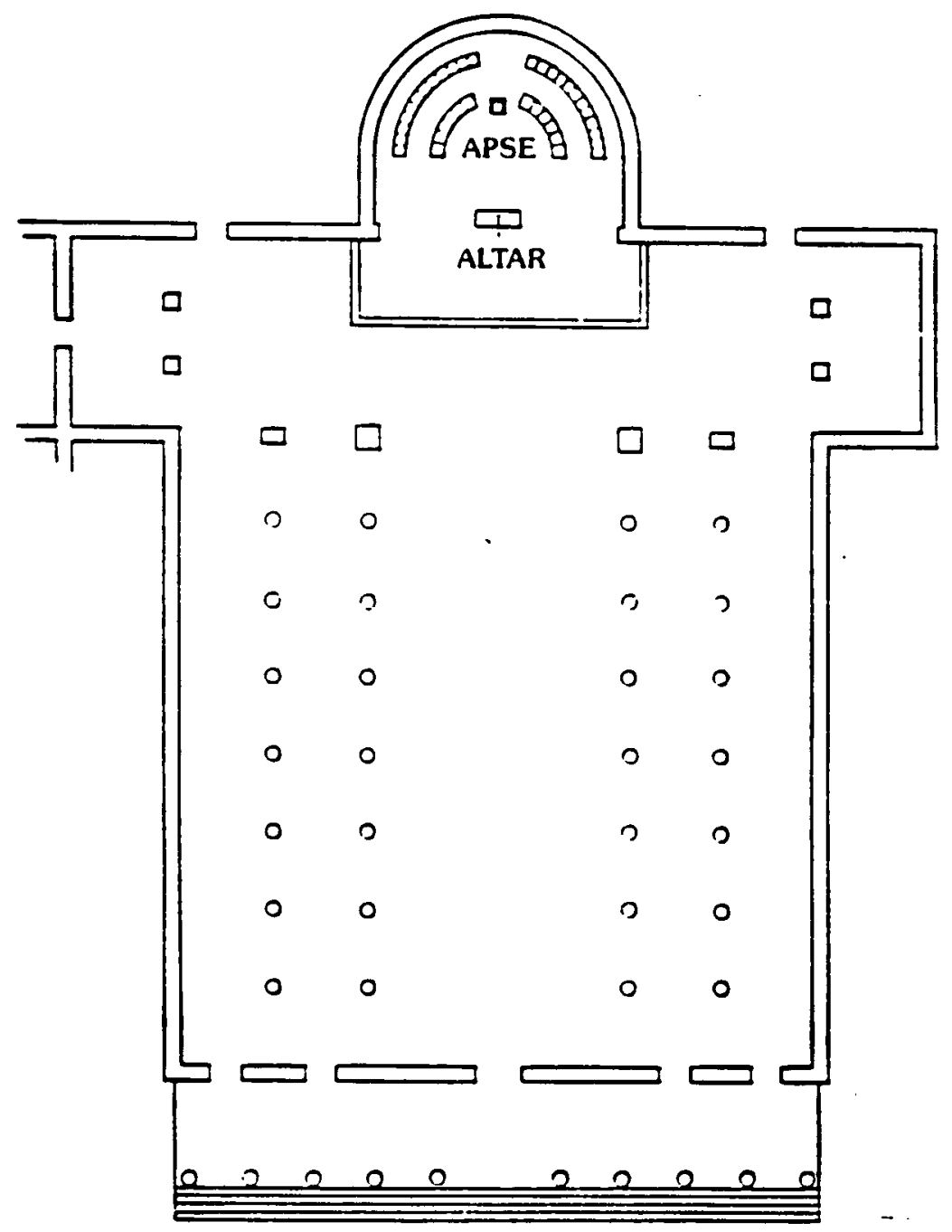

Figure 4. Basilica as place for Christian worship (c. A.D. 450).

Source: Ralph R. Van Loon, "The Church Building," In Space for Worship (Philadelphia: Lutheran Church Publishers, 1975), 6. Reprinted with permission. 


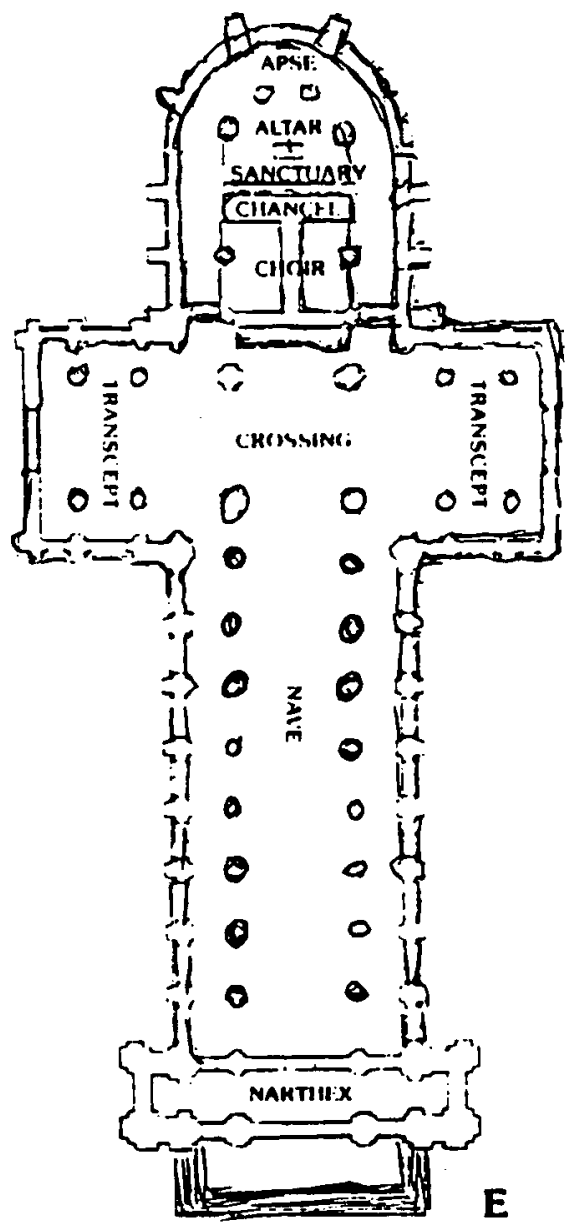

Figure 5. A Gothic design (c. 1200)

Source: Ralph R. Van Loon, "The Church Building," In Space for Worship (Philadelphia: Lutheran Church Publishers, 1975), 6. Reprinted with permission. 

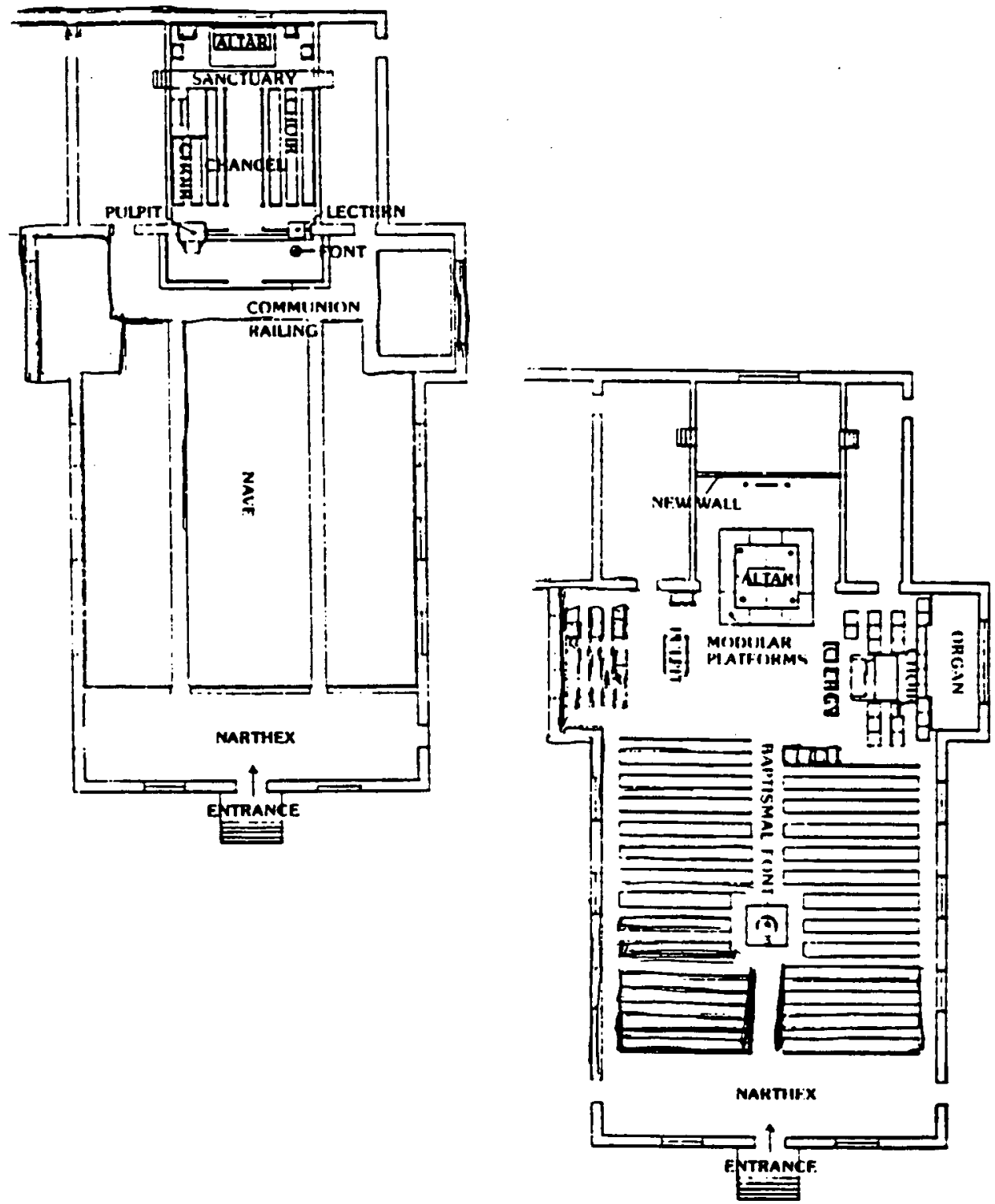

Figure 6. Typical worship space (c. 1925) and reordered worship space.

Source: Ralph R. Van Loon, "The Church Building," In Space for Worship (Philadelphia: Lutheran Church Publishers, 1975), 6. Reprinted with permission. 
the worshippers conforming ministry to the limitations of architectural design from medieval times. ${ }^{1}$

\section{Qrigin and Development of Some Dominant Church Architectural Features and Designs}

It has been suggested that when some people talk about constructing a church building, pictures of existing churches come to mind. For some, the Colonial style and Gothic style, designs originating from medieval times, are perceived as the standard church patterns. Some go as far as attributing a measure of sacredness to these types of structure. John Scotford observes:

When people ask that a church look like a church, what they really mean is that it look like some church with which they are already familiar, either by sight or by means of a picture. This is a natural attitude. We always think of the new in terms of the old. ${ }^{2}$

The question then is, Is there a standard church design that constitutes a church look? A "church look" is usually associated with cathedrals or churches that have certain dominant architectural features such as: long narrow Colonial or Gothic-arched windows with dark, stained pictorial glass; single-story elongated buildings with chancels and naves; thick exterior walls; large decorative buttresses; sometimes high-flying buttresses; high interior sanctuary ceilings with decorative borders; high, sleek bell towers with steeples and crosses on top of them; and marble or stone floors, etc.

We need to understand that when we look at the great cathedrals and their

$$
{ }^{1} \text { Ibid., } 9 .
$$

${ }^{2}$ John R. Scotford, When You Build Your Church (New York: Meredith Press, 1968), 175. 
dominant features, they were not built as a standard pattern for churches or centers of worship, but in many instances their architectural designs were responses to challenges that confronted their builders.

In arguing the case for flexibility and creativity in church architecture, Scotford points out that many of the architectural features and designs of churches coming from the medieval times were developed to provide structural support, combat natural challenges of the environment, and/or meet the socio-religious and educational needs of the congregation and the community in which they were located. ${ }^{1}$

Scotford submits that we know the masterpieces which have survived; we do not know the failures, many of which just toppled over. ${ }^{2}$ He states:

By developing columns and lintels the Greeks managed to get a roof over a sizable room. The Romans wanted light for their interiors and worked out the round arch as a means of getting it without weakening the support of the roof. The builders of the Gothic cathedrals wanted more light for their churches in northern Europe, and so devised the pointed arch. On the other hand, the Moors and then the Spaniards built in lands where there was too much sun, and so they escaped from the heat by reducing the number of windows and putting them in deep recesses. ${ }^{3}$

Scotford asserts that each style of architecture was a brilliant adaptation of the art of building to the needs of the day. Each is a monument to the venturesome spirit of the men of the past. Although many people place high value on the masterpieces, we must be careful to build in a way that suits our present-day needs. ${ }^{4}$

${ }^{1}$ Ibid., 175.

${ }^{2}$ Ibid.

${ }^{3}$ Ibid.

${ }^{4}$ Ibid. 
Addressing the subject of pictorial stained-glass windows, prevalent in medieval church architecture, Donald Speck says: "Stained glass was developed and reached the epitome of its perfection during medieval days. Because of the illiteracy of the people during this time, stained glass was conceived as a pictorial school of the church."1

Today, because illiteracy is not as widespread as in medieval times, we may use either clear or stained glass or a combination of both. According to Speck, the question is, "What purpose do we want it to serve? Remember, windows are primarily for the purpose of transmitting light, not to look at."2

In each of these cases, we see man adapting his building patterns to the challenges facing him, both on a human level and on a natural level. Perhaps the words of Nicholas Wolterstorff are appropriate. He states, "The church, by the architectural style of its building, must announce that it belongs to the present."3

\section{Influences of Church Architectural Design on Liturgy}

Sometimes the question is asked, Can the architectural design of the church influence the congregation's liturgy or can the reverse take place? According to Dr. John G. Davies of the University of Birmingham, England, both are possible. He proposes that anyone who is concerned with the planning of a new building at the present day is confronted with the need for a functional analysis. The client has to provide a clear

${ }^{1}$ Donald H. Speck, quoted in Streeter, 22.

${ }^{2}$ Ibid., 23.

${ }^{3}$ Nicholas Wolterstorff, "Expressing Our Convictions-Some Thoughts on Church Building," The Reformed Journal 23, no. 1 (1973): 11. 
indication of the activities that will take place so that the architect can plan accordingly. ${ }^{1}$

He adds:

Churches in particular are not simply to be regarded as monuments nor as illustrations of a particular period in the development of architecture, nor again solely as objects for aesthetic appreciation, they are also to be 'read' in terms of the liturgical and other functions that they house. Liturgy has in fact influenced church building throughout the ages. ${ }^{2}$

Davies cites four 'laws' which he argues illustrate the alterations brought about within worship by architectural forms. These 'laws' may be formulated as follows. The architectural setting of worship produces liturgical changes if:

1. There is a complete alteration in the style of church buildings;

2. An item of furnishing or an architectural feature, originally introduced for reasons of piety, stimulates a new devotional practice;

3. A use is found for a feature which either had no original specific purpose or has lost its primary function;

4. A group of unrelated buildings are associated in use. ${ }^{3}$

On the other hand, Davies presents two 'laws' which he argues will prevent alterations in worship. He states:

1. Alterations will not take place and indeed, liturgical innovations can be impeded when the existing building has been statically planned;

2. Alterations will not take place when the existing building has attracted to itself the attitude that it is too sacrosanct to re-order. ${ }^{4}$

Robert Carr adds:

The architectural liturgical movement taking place on various continents is

${ }^{1}$ John G. Davies, "The Influence of Architecture upon Liturgical Change," Studia Liturgica 9 (1973): 230.

${ }^{2}$ Ibid.

${ }^{3}$ Ibid.

${ }^{2}$ Ibid., 231. 
unfortunately not realized by the bulk of Christian people. The archiliturgical movement on ecclesiastical-architectural thrust is understood primarily by those who study the church, religious phenomena, or architectural designs for churches. ${ }^{1}$

He points out that this group, made up of clergy, architects, designers, buildingcommittee members, and others, though aware of current trends in architecture and even aware of good designs, is often unwilling to let go of traditional plans and thought processes. $^{2}$ He states:

As a result, masses of Christian people, both on this continent and abroad, are worshipping in buildings made of contemporary material, constructed by contemporary methods but lacking effective solutions to meet their liturgical (worship) needs. ${ }^{3}$

Many today are calling for diversity in church architecture as a result of unresolved needs brought about by liturgical changes. Carr seems to view this as an outcome of the way congregations look at their acts of worship, the needs of their community, and their building design. It seems that architects today are designing versatile plans to meet not only the needs of their worshipping congregations, but also community needs at large. Other scholars cited by Carr who expressed their polemics on this topic are Albert Christ-Janer and Mary Foley. They say:

The reason why the typical medieval plan, with its elongated nave and chancel . . . is being so widely abandoned on the Continent today is the fact it expresses an entirely different understanding of the liturgy, and of the function of the church building, from that now current in Liturgical Movement circles. .. . A new kind of church has begun to appear: a church which reflects a new theological outlook, a deepened

${ }^{1}$ Carr, 19.

${ }^{2}$ Ibid., 5 .

${ }^{3} \mathrm{Ibid}$. 
understanding of the liturgy which gives the building its raison d'etre. ${ }^{1}$

Christ-Janer and Foley seem to be of the opinion that the current experiments

with novel types of church plans based on the square, the circle, the ellipse, and trapezoid are designed to create more corporate participation in the church's liturgy. They say, "They are the outcome of the church's new understanding of itself, and of the liturgy in which its essential character should be more fully realized and made manifest."

\section{Bermudian Churches' Architecture and Design}

The architectural design of most Bermudian churches constructed before the 1980s reflects a dominant blend of Bermudian style with traditional European religious influences. According to Thornton M. Henry,

The churches vary in size and construction from the smallest two-room chapel on the Heydon trust lands in Southampton to the Anglican cathedral in Hamilton, and vary in interior construction from the cedar and ship's-beam laden St. Andrew's Church in the founding city of St.

George's to the utilitarian but modern Seventh-day Adventist church in Warwick. Each warmly opens to members and visitors alike. ${ }^{3}$

Antoinette Deland notes that "changes in Bermudian architecture began as early as 1620 when Governor Moore ordered that a proper State House be built." pointed out that wooden houses with thatched (palmetto leaves) roofs could not

'Albert Christ-Janer and Mary Foley, Modern Church Architecture (New York: McGraw-Hill Publishing Company, 1959), quoted in Carr, 12.

${ }^{2}$ Tbid.

${ }^{3}$ Thornton M. Henry, On This Rock: A Photographic Essay on the Churches of Bermuda (Ontario, Canada: Carter and Carter Publishers, 1993), 12.

${ }^{4}$ Roslyn P. Smith, The Architecture of Bermuda (Bermuda: Smith's Parish, 1985), 2 (in my possession). 
withstand the (frequent) storms (and fires). Moore ordered a "simple and functional building" of natural stone with thick walls, low ceilings, and a flat roof. ${ }^{1}$

David F. Raine's history of early architecture in Bermuda records:

From the time that the State House was completed in St. George's, in early 1620 's, a new trend had been established for all future Bermudian buildings. As the first permanent structure of its kind, the project had become the experimental proving ground-one in which many of the inherently troublesome problems imposed by such different construction techniques, were initially confronted and solved. Even though The State House was fort-like in appearance, it was the architectural embryo from which all other ideas spawned. ${ }^{2}$

Raine further states that Bermudian architecture, as we conceptualize it today, originates from the very earliest stone buildings erected during the seventeenth century.

It bore a mixture of characteristics demanded of the climate and imposed by the nature of the prime building material. Interestingly enough, it also initially reflected the actual personality of many of the original settlers. ${ }^{3}$

Form 1610 and onward, Bermuda's early religious settlers were a mixture of Anglicans, Puritans, Independents, and Presbyterians. Raine contends that they brought to Bermuda the differences and controversies in which they had indulged in England. However, the Puritanical influence was strongest among them. As a result, "the Puritanical presence in Bermuda manifested itself in a simplistic life-style, which influenced the building patterns of homes and other buildings making them purely

${ }^{1}$ Ibid.

${ }^{2}$ David F. Raine, Architecture, Bermuda Style (Bermuda: Pompano Publishers, 1989), 21.

${ }^{3}$ Ibid. 
functional and generally bereft of ornamentation."1

This simplistic lifestyle has continued to influence Bermuda's architecture.

According to Thornton Henry,

Traditional Bermudian architecture is usually quite simple, and several local features, such as whitewashed slate roofs and buttressed limestone walls, have carried over to many of the island churches. Many of the old churches currently standing and being used as places of worship were rebuilt around 1620 and often, they reflected the new concept in building. Using limestone rock cut from local hills and later in more modern times cement block, all buildings are topped by distinctive white lime washed roofs."

Today most churches in Bermuda are still being built along the line and shape of a large rectangle. They have high-pitched gable roofs, which are whitewashed with lime or paint. A unique feature of Bermudian architecture is its roofing system. The under structure of the traditional roofing system is made up of wood. Since the early nineteenth century, steel along with wood is sometimes used together to facilitate large spans, withstand high winds and rain, and storm wind pressures of up to 150 miles per hour. The traditional roof covering is thin hand-cut slabs of limestone called roofing slates. They are approximately one inch thick, twelve inches wide, by eighteen inches long. They are laid over the wood and/or steel support work and held in place by masonry mortar. The overlapping of the roof slates is done in a manner to give them a downstepped appearance.

Although limestone slates are still widely used today as traditional roof coverings, alternative roof coverings have also been developed. Specially treated four-by-eight

${ }^{1}$ Ibid., 41.

${ }^{2}$ Henry, 11. 
sheets of plywood or masonry sheets covered with Styrofoam, or corrugated sheets of metal covered with styrofoam, are sometimes used and then whitewashed. Whatever combination is employed in Bermuda's roofing system, in their finished appearance they resemble the traditional Bermuda slate roof system. (see Appendix $\mathrm{O}$ for further reading) Thornton Henry says:

Bermudian churches do not feature the grand flying buttresses of European cathedrals, but because of the weight of their roof timbers and their coral or concrete slates, even the smallest churches use buttresses to support walls that might otherwise spread and collapse. ${ }^{1}$

Let us now compare some of the features of Bermudian church architecture before and after the nineteenth century. Churches built before the nineteenth century were often large, single-story cathedral-type structures. They have long, narrow Gothicarched windows with dark-stained pictorial glass, high open ceilings, thick exterior columns, deep-pitched traditional slate roofs, masonry steeples, and large cedar entry doors. These churches are usually dark in the interior owing to the narrow Gothic-style windows and dark-stained glass. The walls of the interior and exterior are plastered with cement to a smooth finish. The exterior walls are painted with pastel colors, while the interior walls are painted white or off-white. The arrangement of the furniture in most of the older churches (pre-nineteenth century) conforms to their European mother churches influenced from medieval times.

Most churches built since the nineteenth century have utilized larger and wider Roman-arched windows with clear, bronze, or gray-tinted glass. The inside of these churches tends to be brighter owing to the amount of natural light accessible to the

'Ibid., 119. 
building. The interior walls are usually painted white or off-white. Ceilings are usually high and enclosed in the sanctuary area. They are also plastered with masonry mortar to a smooth surface and painted white. This hard surface contributes to the acoustics of the structure. Roofs are constructed at a lower pitch than the older traditional church roofs; however, the roofing system is still the same as previously described. Both interior and exterior walls are finished with masonry plaster to a high standard of workmanship. The exterior walls are usually painted a pastel color, and most churches today still display religious symbols such as crosses made from limestone or wood, bell-towers, or steeples bearing a metal cross on the top of them.

Although most churches built before the nineteenth century were constructed as single-story structures, churches today are built as two- and sometimes three-story structures. In a two-story structure, the ground level or first floor usually houses the fellowship hall, classrooms, kitchen, and rest rooms. The second story usually houses the sanctuary, baptistry, and administrative areas. In the event there is a three-story structure, then the first or ground floor may be used for storage and other church-related activities such as day-care centers. The second and third floor will then house the activities as mentioned above. It seems evident that churches built in Bermuda since the nineteenth century are constructed to meet the needs of the congregation in this changing society.

\section{Seventh-day Adventist Church Theology, Liturgy, and Architecture}

Most members of churches and centers of worship make every effort to synchronize their liturgical functions and their furniture placement with their theology and 
worship practices. According to Dr. Raymond Holmes:

When Seventh-day Adventists assemble for worship they not only exercise historical memory and remember past events in the history of God's grace, but their faith actively reaches into the realms of heaven itself today. Such faith follows Jesus from the cross to the crown, from the thorns on His brow to the throne of God.'

Within the Seventh-day Adventist Church, owing to differences in theology and worship practices from most Protestant churches, there are variations in its liturgical functions and religious practices. So as to provide some understanding and possible rationale for these differences in liturgical and religious practices, the following areas are addressed:

1. Concept of church

2. A call to flexibility

3. Concept of the sanctuary area

4. Concept of usages of Adventist church buildings

5. The baptistry and the communion table

6. Musical instruments and choir

7. The pulpit: its role and function

8. A call to maintain unique Adventist practices

9. Criteria for judging S.D.A. churches in light of its theology

10. Development of secondary rooms and office space.

\section{Church Concepts}

It seems that some of the early attitudes toward worship, liturgical practices, and church architecture adopted by the Adventist church, may have been influenced by the

\footnotetext{
${ }^{1}$ Holmes, 41.
} 
writings of James F. White (no relationship to E. G. White). Citing the issue of worship White suggested that to many Protestants, worship is primarily a matter of feelings, whereas to others it is work done in service to God! ${ }^{1}$

White went on to say that a better approach to architecture is to analyze the elements of the building which affect the feelings and emotive functions, and then analyze the parts used in performing the work of worship, the liturgical factors. ${ }^{2}$ It appears that James F. White at one time felt too much attention was being given to the appearance of church buildings, and that it is difficult to erect a building that all worshippers would consider worshipful. Therefore, he suggested that a building be designed to function like a machine, to be efficient and economical without the superfluous attention to elegant facades. ${ }^{3}$ His use of two terminologies, "worship atmosphere and emotive factors," serves as the basis for establishing an understanding of the Adventist church's position on liturgical function and church architecture.

According to Robert Carr, James F. White's use of the term "worshipful atmosphere" is constantly found in recent discussions of church designs. It has been found that a worshipful atmosphere (environment) is produced by manipulating the emotional content of the service through appeal to the senses. ${ }^{4}$ White is of the opinion that the emotive factors play a very important role in arousing the feelings often

${ }^{1}$ James F. White, Protestant Worship and Church Architecture (New York: Oxford University Press, 1964), 3, quoted in Carr, 7.

${ }^{2}$ Ibid.

${ }^{3}$ Ibid.

${ }^{4}$ Ibid. 
associated with personal devotions. It is for this reason that concern with regard to the emotive factors is justified. A sense of beauty, whether man-made or natural, can greatly contribute to personal devotions by stimulating the feelings. ${ }^{1}$

Carr again cites James F. White as suggesting that even though emotive factors (aesthetic needs) may be important in church building, they present the problem of mutual agreement on the part of the members as to which emotive factors are necessary. ${ }^{2} \mathrm{He}$ quotes White as saying:

Beyond this lies the problem that a concentration too heavily in the emotive factors can obscure the liturgical factors (worship needs). It has been found that in churches where careful attention has been given to solutions for the liturgical factors, the emotive factors were successful also, although they were given less attention. ${ }^{3}$

The appeal for a balance between aesthetic needs and worshipful needs in church structures has the support of Robert Maguire and Keith Murray:

Once a building is set apart for the House of God, it acquires meanings. If these inherent meanings are not manifest in the architecture, then the building is not "speaking affirmatively." No one need explain architecture. It is understood at a simple fundamental level of consciousness. The effect can be either negative or positive. ${ }^{4}$

Ellen G. White, a pioneer leader of the Adventist Church, promoted the idea of building churches in various styles of architecture to fit their locations. In this, she is in agreement with James F. White and Maguire and Murray with respect to architectural

${ }^{1}$ Ibid.

${ }^{2}$ Ibid., 8.

${ }^{3}$ Ibid.

${ }^{4}$ Robert Maquire and Keith Murray, Modern Churches of the World (New York: E. F. Dutton and Company, 1965), 10, quoted in Carr, 8. 
balance in design and function. Quoting Mrs. White, Carr writes, "Some wonder why Mrs. White always uses the words plain, neat and substantial when speaking of buildings. Her reply was 'It is because I wish our buildings to represent the perfection that God requires of his people'."1

It seems that the concept of a church building as advocated by James F. White and Ellen G. White, calls for a structure to be set aside for the expressed purpose of worshipping God. In this structure, there should be a balance between the worshipful needs (liturgical factors), and the aesthetic needs (beauty) of the congregation. Whilst there is no standard pattern for church structures, they should be designed to meet the needs of the membership and at the same time portray their attitude and appreciation to God for His presence amongst them.

\section{A Call to Flexibility}

The Seventh-day Adventist Church historically has followed the counsel of placing emphasis on liturgical functions rather than on grand architectural designs and flexibility. While many today are advocating flexibility in the use of their church structures, in particular the use of the sanctuary area, the Adventist Church has generally maintained a unique position on this matter.

Bruggink and Droppers give examples of the types of flexibility that many are calling for in church design. They point out the importance of rostrums or liturgical platforms, as they are called by some, being made so that they can be removed or rearranged—one side to be carpeted and the other side smooth wood. The carpet side is

\footnotetext{
${ }^{1}$ Carr, 11.
} 
used when noise should be kept to a minimum and the wood side to be used for play, drama, or dance. The baptismal font can be placed at the entrance or the center of the congregation depending on the type of baptism which takes place. Sunday evening meals could be served in the sanctuary just before an informal worship service where members may sit on the floor around the rostrum, if they wish. The piano and organ would be placed on casters so that they can be moved in and out of the sanctuary as the need arises. $^{1}$

Reverend Edwin C. Lynn advocates that the pulpit no longer needs to be attached to the building's interior but can be mounted on wheels allowing placement in any part of the sanctuary. ${ }^{2}$

There is an admission on the part of those advocating flexibility that such flexibility would not be appreciated by all church members, but Bruggink and Droppers assert that once people begin to witness the different kinds of worship experiences, they will see its purpose and appreciate its beauty. ${ }^{3}$

\section{The Concept of the Sanctuary Area}

Ellen $\mathrm{G}$. White gives the most direct statement that offers some rationale for the historic position with respect to the usage of the sanctuary area as practiced by the Adventist church. She urged that there should be a sacred spot like the sanctuary of old,

${ }^{1}$ Bruggink and Droppers, quoted in Carr, 15.

${ }^{2}$ Edwin C. Lynn, "Shaker Spaces: The Psychology of Simplicity in Religious Architecture," Your Church, October 1974, 16-17, quoted in Carr, 16.

${ }^{3}$ Bruggink and Droppers, quoted in Carr, 15. 
where God could meet with His people. That place should not be used as a lunch room or as a business room, but simply for the worship of God. She went on to say that when children attend day school in the same place where they assemble to worship on Sabbath, they cannot be made to feel the sacredness of the place and that they must enter with feelings of reverence. She was very concerned about blending the sacred and the common. It was for this reason that she advocated that the sanctuary dedicated to God should not be made a common place. ${ }^{1}$ She went on to say:

Its sacredness should not be confused or mingled with common everyday feelings or business life. There should be a solemn awe upon the worshippers as they enter the sanctuary, and they should leave behind all common worldly thoughts, for it is the place where God reveals His presence. It is as the audience chamber of the great and eternal God; therefore, pride and passion, dissension and self-esteem, selfishness, and covetousness, which God pronounces idolatry, are inappropriate for such a place. $^{2}$

At the same time Mrs. White calls attention to recognize the special purposes of the sanctuary. She makes two provocative statements that call for serious examination. She says that:

There is no part in a Seventh-day Adventist Church which is more sacred than another part. The rostrum is no more holy than the sanctuary itself, and the pulpit is not a more holy piece of furniture than other pieces of furniture in the church.

The sanctuary in the church is not the only place that God reveals His presence,

${ }^{1}$ Ellen G. White, "Building a House for God," MS 23, 1886, Ellen G. White Research Center, Andrews University, Berrien Springs, MI, 7.

${ }^{2}$ Ibid., 8. 
neither is His presence found only there. ${ }^{1}$

Upon first reading these statements, one may have a sense of confusion and concern. But examining these statements, one can discover the extent of her meaning. In this regard, Mrs. White states, "Seventh-day Adventists do not hold the position of a sacred altar in the church. As Protestants, we keep far away from ceremonialism and ritual forms. Our worship is from the heart, and the Protestant minister stands in the pulpit, opening to the flock the Word of God."2

Carr suggests that what Mrs. White implied in her statement is that the sanctuary, given proper preparation on the part of the worshipper, provides a special mode of theophany, because it is the chosen place of God. ${ }^{3}$

There is a similar concept in that of the Sabbath. We can experience God's presence on any other day, but we can experience it in an unusual manner and to an unusual degree on God's chosen day. Mrs. White does not portray a picture of the church building as a shrine of some localized Deity, but rather as a place of specified appointment with transcendent Deity. ${ }^{4}$

In light of the counsel from Ellen White, we may conclude that the sanctuary area is not to be treated as a shrine dedicated to a local god. But the fact that the sanctuary area is dedicated to the worship of God should encourage us to show respect for its purpose and as such curtails certain types of activities. It is important for a pastor and a

${ }^{1}$ Arthur L. White to W. W. Menshausen, 10 April 1964, Q and A File 16-0-1, Ellen G. White Research Center, Andrews University, Berrien Springs, MI, quoted in Carr, 21.

${ }^{2}$ Ibid., 22.

${ }^{3}$ Ibid.

${ }^{4}$ Ibid. 
congregation when constructing a church to first determine their priorities. If they need a multi-purpose room where worship and other social functions can take place, they may want to construct that area first and leave the sanctuary area as a last phase of building. In this way they can be in harmony with the counsel given by Ellen $G$. White, and historically practiced by most Adventists.

\section{The Concept of Church-Building Usage}

In clarifying some of the usages of an Adventist church building, Arthur L. White said that we usually have two types of facilities. There is the main church sanctuary, which is dedicated to the worship of God, and all services in this sanctuary must be in keeping with this dedication that sets it apart in a very special way as a place of worship; in addition, there are secondary rooms used for social and secular activities. ${ }^{1}$ He continues:

We usually have Sabbath School rooms, sometimes recreational rooms, a kitchen and fellowship hall, and so forth. While in the overall program, this too, is dedicated to God's service, these facilities are used for secular purposes. These may be in the church building itself rooms devoted to church-related activities, which are of a character different than the worship service, but more of a secular type of gathering. ${ }^{2}$

In harmony with Arthur White's counsel, most Adventist churches in the

Bermuda Conference have two or more stories. The sanctuary area is usually housed on the upper level, while the lower levels provide secondary rooms such as a fellowship hall,

${ }^{1}$ Arthur L. White to Richard Hawley, 20 October 1971, Q and A File 16-0-2, Ellen G. White Research Center, Andrews University, Berrien Springs, Michigan, quoted in Carr, 22-23.

${ }^{2}$ Ibid. 
classrooms, a kitchen, and restroom facilities. These buildings provide flexible use for church and secular programs that are related to the life and mission of the church and outreach to the community.

\section{The Baptistry and the Communion Table}

The subject of the baptistry and communion table as cited by Garrison Webb sums up what seems to be the Adventist attitude toward these two liturgical centers. He writes:

The baptistry and communion table are excellent reminders of the atonement of Christ. Therefore these prime liturgical centers should be placed where people can see them. No other function of the church, not even the preaching of the Word, is so effective in bringing God's grace to sin-burdened man. ${ }^{1}$

This statement highlights the significance of the baptismal pool and the communion table. In most Adventist churches these two liturgical centers are usually located in a central position, although from time to time they may be located slightly to the side of a pulpit area. The communion table is generally located immediately below and in front of the pulpit, while the baptismal pool is behind the pulpit area and choir loft. It is usually mounted so that it can be visible. The communion table houses the symbolic emblems of the Lord's Body and Blood during the times the communion service is celebrated. Unleavened bread and grape juice are used as symbolic emblems. The communion table symbolically represents the great provision of atonement that Jesus provides and His promise to eat the 'supper' anew in heaven (1 Cor 11:24-29). Its

${ }^{1}$ Garrison Webb, "Wesley's View of Baptism and the Lord's Supper," Ministry Magazine 28 (April 1955), 36, quoted in Carr, 21. 
central location just before the pulpit can also symbolically portray God's continual provision of grace and mercy before proclamation and instruction is given from week to week.

The baptismal pool on the other hand is a symbolic gateway into the church. There sinners can follow the example of Jesus in baptism by immersion. They can experience symbolic death and burial from a life of sin and a resurrection to walk in newness of life through Jesus Christ our Lord (Matt 3:16-17; Rom 6:3-5; Col 2:12). The baptismal pool should always be visible to the congregation as a reminder of its purpose and work in man's salvation. As a result, there should be no visual hindrance in witnessing baptisms. The baptistry should be wide and deep enough to allow an individual to be fully immersed in its waters. It is also recommended that the baptistry be fully tiled to ensure good sanitary conditions.

\section{Musical Instruments and Choir}

Writing on the topic of musical instruments and choir in church, Ray Santini said:

Liturgical centers of secondary importance include the instruments and designated choir area. Many arrangements have been used either eliminating the choir altogether or placing it in extreme prominence. It is suggested that since Adventists incorporate a "pulpit-centered worship," they allow the choir and instruments to be of lesser importance. ${ }^{1}$

Any pastor and congregation building a church need to carefully consider suitable locations for musical instruments and the choir area in the sanctuary. Great care also needs to be given in equipping classrooms with quality musical instruments. Since in Carr, 22.

'Ray Santini, “The Choir Loft," Ministry Magazine 26 (January 1953): 40, quoted 
preaching is central to the liturgical function in the worship service of the Adventist church, musical instruments and the performance of the choirs must be seen as a complement to the worship experience. On this basis, placing the instruments on a lower level as suggested by Santini can assist in preventing them from overshadowing or overpowering the significance and presence of the pulpit. We may all agree that music is beneficial to the life and flow of the church service, and singing by the choir provides inspiration for the worshipers. But they should be kept as a complement to the preaching of the Word. While most choir lofts are usually situated behind the pulpit, and the musical instruments on a lower level on either side of the pulpit, symbolically portraying support to the ministry of the Word, it is necessary that adequate space be provided so that each can fulfill its purpose.

\section{The Pulpit: Its Role and Function}

Regarding the pulpit, its role, functions, and location, counsel from James F. White has been most instrumental in helping to shape our attitude and practice. Carr points out that White stresses the importance of the pulpit as a liturgical center of Protestant churches. White says, "The pulpit is not just a stand for oratory, but is veritably the throne for the Word of God."1 White contends that the shape of the pulpit can give a sense of the divine-human encounter possible in preaching. "This is especially true when the pulpit is solid and substantial enough to suggest authority far higher than the preacher's personality."'

\footnotetext{
${ }^{1}$ A. L. White, quoted in Carr, 16.

${ }^{2}$ Ibid.
} 
James F. White advocated that the best position for the pulpit and the preacher is a central one. In the event that the church is designed in a circle, the pastor should make every arrangement so that he can have eye contact with his congregation. White was of the opinion that preaching is at the heart of Protestant worship, and that as the preacher stands in the pulpit opening to his flock the Word of God, he becomes the central figure as God's spokesman, his representative, his ambassador on earth. ${ }^{1}$

Many may question the authority of James White in advocating that the pulpit be centrally located and constructed in a solid and substantial way to suggest authority beyond the preacher's personality. I am of the opinion that White's position has merit, for preaching is central to the Bible and our Protestant Christian heritage. The preacher is usually accepted as God's messenger. Therefore the central location of the pulpit is both a symbolic and practical attribute to the process of communicating God's message. In saying this, I am not denigrating pulpits which have been placed off center, as is the case of some churches. However, one may suggest when non-central positions are selected for location of pulpits, something may be lost in transmitting some symbolic or communicative opportunities.

While pulpits have historically been built of solid wood, employing the use of transparent materials, as seen today in some churches, should not lessen the value or significance of them, as it is referred to by James F. White as a throne for God's Word. They need to be constructed in such a way as to represent their function. What we need to keep in mind at all times when we consider the pulpit is that when we stand behind it

${ }^{1}$ Carr, 21. 
we represent God with His message for His people.

\section{A Call to Maintain Unique Adventist Practices}

Robert Carr contends that various differences exist between ideas of church designs, worship practices, and flexibility of church usages, between Protestants and the guidelines suggested by the Seventh-day Adventist leaders. ${ }^{1}$ He says, "It is only logical to point out that since the beliefs and the needs of Seventh-day Adventists decidedly differ from current trends, then the designs for this denomination will also be decidedly different."2

Dr. Raymond Holmes cites that the Seventh-day Adventist Church managed to avoid, to a large degree, the experimentation with new forms of worship which took place in the 1950s and 1960s in other church bodies. ${ }^{3}$

He said, "During this period the Seventh-day Adventist Church stood like a rock for historic Biblical Christianity." ${ }^{4}$ He mentioned two reasons for that. He said that first of all, the Adventist Church did not lose sight of the Biblical message, that the Bible was the inspired written Word of God, or that when its message of redemption was preached people would hear and respond in faith and find salvation. The second factor cited was that of the strong influence of the writings of Ellen G. White.

\footnotetext{
${ }^{1}$ Ibid., 23.

${ }^{2}$ Ibid.

${ }^{3}$ Holmes, 4-5.

${ }^{4}$ Ibid,. 5.

${ }^{5}$ Ibid.
} 
Carr seems to be of the opinion that the architecture of many churches is not highly representative of their theology and that further changes were taking place within them. However, he warns that the Seventh-day Adventist Church must be careful not to join the archi-liturgical bandwagon and accept change for the sake of change. He feels that there should be rigid factors in each theology that can be represented by the church's design. ${ }^{1}$ He states, "The principles set forth in the review of literature by Ellen White and other church leaders should produce archi-liturgical unity in the denomination, but should not stifle creativity."2

\section{Criteria for Judging and Constructing Seventh-day} Adventist Church in Light of Its Theology

The following guidelines condensed from the foregoing review of literature can be used as criteria for judging and constructing a Seventh-day Adventist church in terms of its theology.

1. Because of the sacredness of the sanctuary, it should be designed for worship services only.

2. The pulpit is the most important part of a Seventh-day Adventist church interior, and should be centrally located.

3. The communion table, secondary to the pulpit, should be in a prominent place as an important reminder of Christ our intercessor.

${ }^{1}$ Carr, 24.

${ }^{2}$ Ibid. 
4. The baptistry should be revealed at all times as an important reminder of one's entering the faith.

5. Instruments and choir should be placed so that they are not in any way centers of attraction, for they augment the worship service.

6. The structure should be economical in relation to the socioeconomic strata of its environment.

7. The structure should be designed to represent the life of Christ by simplicity, solidness, and perfection of construction without extravagant ornamentation.

8. Secondary rooms should be provided for classrooms, social gatherings, and functions of a more secular nature.

9. Beauty should be seen as a part of the functionality of the design and should be an integral part of an effective design and choice of materials. ${ }^{1}$

10. Every effort should be made to use genuine building materials and plant life in the sanctuary area.

It should be noted, that Seventh-day Adventist church-buildings usually place an emphasis on function over style and size of structure. The use of a single chancel, in which the pastor and choir faces the congregation in worship and ministry, lower sanctuary ceiling heights as previously suggested, predominant use of clear glass windows as opposed to a heavy concentration of stain-glassed windows, a seven to ten foot space separating the first row of pews from the pulpit, pews arranged in a semicircular or parallel formation as space permits and the sanctuary floors fully or partially

${ }^{1}$ Ibid., 25. 
carpeted. These features help to create a sense of intimacy and at the same time enough space can be allowed to portray a sense of God's transcendency.

It seems that Adventist liturgical practices have been influenced by its understanding of the O.T. sanctuary/temple systems and the N.T. teachings on the role and function of the church. In addition the church sees itself symbolically aligned affiliated with the functions of the heavenly sanctuary and believes that both the churchstructure and the lives of its members, should reflect the soon return of Jesus.

\section{Development of Secondary Rooms and Office Space}

James L. Doom, consultant of architecture and art for the Presbyterian Church in the United States, declared at a meeting's keynote address:

People wait to be involved in the action of worship. Proclamation, devotion, learning, service and fellowship are all a part of worship. While each can stand on its own, none is complete without the other. Buildings that have isolated devotion in one structure from learning in another, with hospitality in a third and with service to the community ignored, have been 'heretical buildings.'

The implication of Doom is that buildings must be flexible with multi-purpose capacities. When one observes most Adventist structures one will notice that there are attempts to provide a total program of nurture and activity for its members. The practice of constructing secondary rooms allows for the implementation of many of the facets Doom cites as being a part of worship. According to the guidelines based on the review of Adventist literature, further elaboration is warranted regarding secondary rooms used for classrooms, social gatherings, and functions of a more secular nature.

${ }^{1}$ James L. Doom, quoted in Willmar L. Thorkelson, "Integrated Buildings, " Christianity Today Magazine, July 6, 1973, 44. 


\section{Church's Main Entrance/Narthex}

An area in the architectural design of a church building which can be instrumental in creating a first good impression to the member and visitor is the narthex or main entrance area into the church building. This area is usually located after the entrance through the main doors of the church, but just prior to entry into the sanctuary area itself. Ralph Van Loon highlights the usefulness and benefits of such an area in this way:

The narthex is the name given to the entrance hall of the church building. The narthex separates the worship room (sanctuary) from the distracting noises of the outside and becomes a kind of transition zone for the worshipper, a preparation space, a place to prepare for the liturgy that is about to happen. ${ }^{1}$

Van Loon says that the narthex gives worshippers their first impression of the church building. Obviously, it should always be neat and convey a sense of warm hospitality. He goes on to suggest that it should be an area free of any hindrances. While such a public space may be the most logical place for the parish bulletin board and for special-emphasis posters, some restraint should be used. One should at all times be careful to keep the narthex attractive and tidy. ${ }^{2}$

I am in agreement with Van Loon that there are benefits of having a properly designed area where members and visitors can meet in final preparation before entrance into the sanctuary area. Many of the older churches in Bermuda have narthexes that are considerably small and restrictive of certain types of activities. Today, many churches are

\footnotetext{
${ }^{1}$ Van Loon, 11.

${ }^{2}$ Ibid.
} 
being built with larger narthexes. The following list can serve to point out ways a narthex can be developed:

1. The narthex needs to be well designed, adequately lit, and attractively decorated.

2. The narthex needs to be large enough to permit worshippers entering the church to greet one another before and after the services.

3. The narthex needs to provide easy formations for processions, such as choirs, graduations, wedding parties, greetings and reception lines for pastors and elders before and after services.

4. The narthex needs to be large enough to accommodate a casket and a limited formation line for the mourners' processional.

5. The narthex needs to be large enough to accommodate an usher, a greeter, and necessary furniture to hold the visitor's book, church bulletins, inserts, and free religious literature.

6. The narthex needs to be constructed with doors which can separate its activity and sound from the sanctuary area.

7. The narthex needs to be kept neat and clean at all times.

\section{Classrooms for Study and Teaching}

In the Adventist church much care and attention is directed to the spiritual development and nurture of its children, early teens, youth, and adult membership. This is first attempted outside of the home through the ministry of the Sabbath School division of the church. The Sabbath School division of the church meets on a weekly basis every 
Sabbath morning, for approximately one hour and ten minutes before the eleven o'clock divine worship service.

According to the Seventh-day Adventist Church Manual, the Sabbath school has rightly been called "the church at study." It is one of the most important services held in connection with our church work. Sabbath by Sabbath the greater part of our membership and thousands of interested friends meet in Sabbath school to study God's Word systematically. ${ }^{1}$

Instructional materials incorporating biblical themes are specially developed for all age groups of the church's membership. The following age groups are usually provided for in most Adventist churches:

1. Group I--Cradle Roll--infants to 3 years old

2. Group II--Kindergarten--4 to 6 years old

3. Group III--Primary--7 to 9 years old

4. Group IV--Juniors-- 10 to 12 years old

5. Group V--Earliteens--13 to 15 years old

6. Group VI--Youth--16 to 19 years old

7. Group VII--Young Adults--20 to 35 years old

8. Group VIII--Adults--36 years and up.

In an effort to fulfill the general goals of the Sabbath School, that of spiritual nurturing and learning through teaching and discussion of topics from the Bible, each group usually meets in separate classrooms according to their age/group. In most cases the adult division utilizes the main sanctuary area for its preliminaries and then separates

${ }^{1}$ General Conference of Seventh-day Adventists, Seventh-day Adventist Church Manual (Washington, DC: General Conference of Seventh-day Adventists, 1986), 83. 
into smaller classes/study groups within the same area. According to Van Loon, "a vital sense of belonging is produced by shared study and small group discussions."1

The number of classrooms in a church building may vary according to the availability of building space and financial ability of the church. However, every effort should be made when constructing a church building to facilitate the needs of the Sabbath School division.

\section{Fellowship Hall}

Two questions sometimes asked by church members are: "How important is a fellowship hall? and Why should a church have one?" Ralph Van Loon says that fellowship occurs in all spaces of the church. There is the conscious fellowship of the congregation in corporate worship. There is lively fellowship in the exchange of ideas and in friendly conversation in corridors and around tables at a meal. ${ }^{2} \mathrm{He}$ went on to say:

The building committee should recognize that a strong sense of fellowship, so important in the life of the church, is heightened by attractive, comfortable rooms, and other areas where people meet. Every church regardless of size, needs a fellowship room, a space where the entire church family can meet for meals, recreation, lectures, drama, audio-visual, special programs and work groups. There, the church family shares its common concerns. From the group life and all-church meetings that occur within the fellowship room, children, young people and adults absorb something of the meaning of the church and its mission. ${ }^{3}$

From my observation, fellowship halls are most useful and convenient for

${ }^{1}$ Van Loon, 83.

${ }^{2}$ Ibid.

${ }^{3}$ Ibid. 
Sabbath gatherings, community guest-day luncheons, and Agape feasts. All eight churches in Bermuda Conference have fellowship halls as part of their physical structures. Many of them are being utilized during the weekdays for senior citizens day-care programs, after- school care, nursery centers, and feeding centers for the homeless. Periodically other functions are hosted such as wedding receptions, monthly community service meetings, Pathfinder meetings, health lectures, and classes in nutrition and vegetarian cooking. Many visitors have had their first introduction to vegetarianism at luncheons or cooking classes, which is one of the distinct practices of the Adventist church.

Fellowship halls provide congregations the flexibility of usage necessary to conduct ongoing activities for special interest groups, from serving as a recreational venue for the youth, to hosting church-sponsored banquets. Gourmet committees are provided the opportunity to be creative in their decorations and unhindered to make early preparations for special events.

In these times when many church planners are calling for flexibility in church architectural design for more than one usage, the practice of the Adventist church in providing fellowship halls has proven satisfactory to meeting the needs and demands being made on the total church program. I, therefore, recommend to those pastors and congregations building a new church to include a fellowship hall in their plans.

\section{Kitchen Area}

If there are two areas in a church which can be tied together because of their benefits to the congregation's ongoing liturgical functions, they are the fellowship hall 
and the kitchen area. A kitchen area is ideal for the preparation and cooking of foods while the fellowship hall is ideal for hosting different types of seminars. Owing to its functions, kitchens as much as possible should be situated close to the fellowship hall with clear and easy access to the outside of the building. Every effort should be made to equip the kitchen with adequate windows which open to the outside, and non-skid tile floors or a hard surface. According to Ralph Van Loon, "the cooking and dishwashing facilities should be located so noise does not disturb meetings in the fellowship hall."1 From my observation, churches equipped with kitchens usually have people willing to work on the Gourmet committee. Kitchens equipped with commercial appliances, or regular household appliances, provide opportunity for easy and convenient preparation of food. This negates the need of members having to travel with quantities of prepared food from their homes for church functions.

The presence of church kitchens also has the potential for encouraging members to spend more time at church, particularly those who live great distances away. When weighing the value of a kitchen, like Van Loon, it is difficult not to agree that every congregation should strive in their building to establish one. (See Appendix L for further reading).

\section{Acoustics and Lighting}

Among the many essential features of a church-building, none are more important than the quality of the acoustics and the interior and exterior lighting. Often thousands of dollars are spent on carefully constructing a church-building, but little professional input

${ }^{1}$ Ibid., 84. 
and money is spent on securing adequate acoustical and lighting features.

A quality acoustical environment of a church-building can be created by providing hard surfaces that allow sound to bounce from wall to wall or ceiling to floor and so on. Creating an atmosphere where the worshippers can comfortably hear what is being preached, sung, or played on instruments is essentially the reason for which the church was erected (Rom 10:17). Every care should be taken to provide a balance in materials that absorb sound and materials that reflect sound. Plastered ceiling and walls and partially carpeted floors trend to facilitate good acoustical potentials for projecting voices and musical instruments. A good quality sound system and trained technicians can assist in balancing the speaking and hearing levels. Great care needs to be exercised in keeping the building acoustically alive for it will enhance the worship and singing experience of that congregation.

Let us briefly consider the interior and exterior lighting of a church-building. Both of these features can positively influence a worshipper's attitude and contribute to the quality of the service. Because the Bible is frequently read and hymns and other music sung or played in most Adventist services, adequate lighting is needed especially for the elderly. According to the size of the church both the interior and exterior areas should be well illuminated, for light has the capacity to generate warmth, good feelings, and serve as protection. (See Appendix $\mathrm{E}$ for further reading.)

Another area of growing need for church-buildings in these times is that of structural provision for the disabled and aging population. Scripture clearly indicates a theological concern for the care of the elderly and disabled (Ps 71:9; 1 Tim 5:8). In the past twenty-five years many governments have revised construction codes to mandate 
inclusion of disability facilities in church structures (see Appendix $Q$ for further reading). Gently sloping ramps for easy access to all parts of the church-building, support rails and specially equipped bathrooms, are of paramount importance to provide opportunities for worship and fellowship among its people.

\section{Administrative and Stewardship: The Office Areas}

Older church buildings erected in Bermuda before the 1980s were usually built at a time when the needs of the congregations could be met by one pastor with minimum church administration needs. Today, owing to changing trends and our complex societies, churches are requiring more diversity of services and administration to meet the needs of their members and fulfill their mission in the community. Dr. Edward Streeter, professor at Andrews University and church architecture consultant, stated that the administration area of the local church involves different items such as money, things, programs, and, most important, people. As a result, activities can be classified into those of planning, processing, and evaluation. ${ }^{1}$

Dr. Streeter pointed out that there is now a trend in the S.D.A. Church to recognize the abilities that are present in the local church membership. He suggests that ideally the local church, working in relationship with the pastor, prepare church programs to meet members' capabilities and the needs of their community. ${ }^{2}$ To accomplish this, Dr. Streeter suggested that buildings today need to include a purpose-constructed area. He says:

${ }^{1}$ Streeter, 1.

${ }^{2} \mathrm{Ibid}$. 
The administrative area is no longer just a couple of rooms only for the pastor and/or associate pastor and a secretary, but is a leadership center and a center for member and church officer services, as well as a center for business management. Administrative facilities are units of control, communication, and coordination and should normally occupy a controlling and readily accessible position within a building complex. For that reason, on entry of the church grounds, visitors should, by its mere location, meet up first with indications of the administrative center; high visibility and easy public access are paramount. ${ }^{1}$

\section{Adventist Church Design}

In light of the liturgical functions and differences of the Adventist church from other churches, one may question, "Is there a standard design for Adventist churches?" From the counsel of Ellen White, we have this answer, "Churches are built in many places, but they need not all be built precisely the same style. Different styles of building may be appropriate to different locations."

Mrs. White used as her point of reference the breastplate of the high priest in which there were many stones, each one having its own shape, special light, and significance. They all added to the beauty of the whole as they bore important messages from God. She says, "There were many stones but one breastplate so there are many minds, but one mind. In the church there are many members, each having his peculiar characteristics but they form one family. ${ }^{3}$

The Seventh-day Adventist Minister's Manual, poses four basic questions regarding the design of an Adventist church building.

${ }^{1}$ Ibid., 2.

${ }^{2}$ White, Evangelism, 379.

${ }^{3}$ Ibid., 380. 
1. Is it attractive?--Seventh-day Adventists extol simplicity and elegance, yet they recognize that God allowed a significant display of beauty in the wilderness tabernacle and seemed to bless in the building of rather lavish Old Testament temples.

2. Is it functional?--What functions other than Sabbath morning worship will be held in the building? Is ample provision being made to meet the spiritual and social needs of the adult, youth, and children populations of the church?

3. Is it flexible?--Is the building designed to accommodate all the worship practices and programs which will satisfy the needs of the membership and its mission to the community? Consideration must be given to the acoustics and to the size of the rooms that will be constructed.

4. Is it intimate?--Historically, church sanctuaries have tended to be long and narrow, separating the worshipers from each other and from their worship leaders. Today, experiments in church designs are providing people the opportunity of sitting closer to one another and their worship leader. ${ }^{1}$ The Manual states:

A part of worship is fellowship--people getting together with one another and together with God. Ideally, sanctuaries should be shaped so worshipers are close to one another and close to, if not surrounding, their worship leaders. The pulpit is usually located in the center of the platform to emphasize that the preaching of the word is central to Adventism and Adventist worship. ${ }^{2}$

\section{Church Location/Site}

Location is among the many important decisions to be made when considering

${ }^{1}$ General Conference of SDA, Ministerial Association, SDA Minister's Manual, (Silver Spring, MD: General Conference of SDA, 1992), 180.

${ }^{2}$ Ibid., 181. 
the construction of a church facility. Ezra Earl Jones in a maxim on church location said, "If you need a sign to tell you where the church is, the church should be where the sign is."

Ellen G. White admonishes "that in every city where the truth is proclaimed churches are to be raised up. In some large cities there must be churches in various parts of the city. In some places, meeting houses will be offered for sale at reasonable rates, which can be purchased advantageously." ${ }^{2}$ The SDA Minister's Manual advocates that in building a church, three factors are of prime importance: the first is location, the second is location, and the third is location. ${ }^{3}$

The Manual suggested that there are at least five issues that should be considered in choosing a church location:

1. Centrality and accessibility--Is the area well populated? Are people moving away from the area or into the area? Will the area facilitate a day-care center or will it attract people to it?

2. Visibility--Is the location visible from the main flow of traffic? Is it prominent in the community?

3. Cost--Sometimes inexpensive land is purchased to avoid financial burden. However, a congregation needs to understand that certain areas do not readily attract people and in the long-term may prove to be a poor area for a church setting.

\footnotetext{
${ }^{1}$ Lyles, 807.

${ }^{2}$ White, Evangelism, 377.

${ }^{3}$ SDA Minister's Manual, 179.
} 
4. Size--Is the size of the area able to accommodate a church building with the potential of expansion and is there enough land to satisfy the various social functions of the church?

5. Restrictions--Before a piece of land is purchased or accepted as a gift for a church, the zoning of the area must be thoroughly investigated. Also, the title or deeds of the property must be checked to see if they are clear. All transactions should be done with legal counsel and advice. ${ }^{1}$

Selecting a location for a church building is of extreme importance. It is very critical that those responsible for such a choice seek the wisdom of God before making that choice. (See Appendix $\mathrm{F}$ for further reading.)

\section{Church Maintenance and Insurance}

Let us now consider the subject of church maintenance and insurance. Before the completion of a new church building it would be prudent for the pastor and congregation to commence planning for the church's ongoing maintenance and insurance. Ellen White admonishes: "His people today are to remember that the house of worship is the Lord's property and that it is to be scrupulously cared for, but the funds for the work must not come from the tithes."2

At some time Mrs. White was concerned about the way God's property was being handled. She asked, "Can those who are representative men be so sound asleep

${ }^{1}$ Ibid., 179-180.

${ }^{2}$ White, Gospel Workers, 226. 
that they do not comprehend that the state of things that exists is a result of neglect on their part?"1

She was referring to the state of the church and comparing the homes of the members to the way in which they had allowed the church to fall into a state of disrepair. She said that they had embellished their own houses and had demonstrated selfishness in the use of their money. She went on to urge that God's house should be kept in the very best condition. ${ }^{2}$

The SDA Minister's Manual points out that most unattractive churches are that way, not so much because they are old or poorly built, but because they are poorly maintained. Neatness, cleanliness, and tasteful interior decorating are not expensive. It is amazing how much difference a little paint can make. ${ }^{3}$

The Manual continues by stating,

Congregations can become so comfortable in their church surroundings that they no longer notice the deficiencies. Deacons and other church leaders should periodically view the building as though they were visitors getting their first impression. A checklist may help their evaluation of: yard, sign, exterior paint, foyer, interior decorating, restrooms, fire protection, etc. ${ }^{4}$

Associated with the need for an ongoing maintenance program in a church building is the need for a congregation to carry adequate building insurance. The SDA

${ }^{1}$ Ellen G. White, Counsels on Stewardship (Washington, DC: Review \& Herald, 1940), 261.

${ }^{2}$ Ibid.

${ }^{3}$ The SDA Minister's Manual, 181.

${ }^{4}$ Ibid., 182. 
Minister's Manual advocates that "church facilities should, of course, be insured in accordance with conference/mission policies. It's presumptuous to expect God to protect us from our own indolence."

From personal observation some congregations are more diligent in implementing a church maintenance program in the early months and years of occupancy of a new building. However, as time progresses, many fail to follow a long-term approach of meeting its maintenance needs. Counsel from both Ellen G. White and the SDA Minister's Manual clearly indicate the benefits of conducting a continued program of maintenance for the church. I am of the opinion that if a pastor and his/her congregation have been blessed to construct a church building and consider that a blessing as a trust from God, then they should be willing to consider an ongoing program of maintenance and insurance of that building as a part of that trust. It can be said that a well-kept and orderly church facility is a credit to the gospel of Jesus Christ and the trusteeship of its pastor and members.

\section{A New Building/A New Beginning}

Speed Leas warns that many denominational leaders and church consultants have commented that the completion of a church building can be a time of conflict and jeopardy for the pastor. ${ }^{2}$ Leas quotes Don Met as saying:

Inherent in every congregation is a conflict between its concern for

${ }^{1}$ Ibid.

${ }^{2}$ Speed B. Leas, Moving Your Church through Conflict (New York: Alban Institute, 1985), 79. 
security and its concern for ministry. In its building phase, one side of that tension has ascendancy. When the church finishes its building phase, it must face again the question of who it is, what it is for, and how it will focus the energies of its members. ${ }^{1}$

Leas goes on to point out that some people see this shift in focus as a call for a shift in leaders and leadership patterns. There are people who do well at concrete tasks and the organization or personnel to complete those tasks, but their vision of ministry may not be strong in programs of church outreach and Christian nurture. As a result, so often when building tasks are complete there is competition for leadership among the congregation to fill the vacuum left by the withdrawal of the exertion required in the large task of erecting a building. It will help everyone to be aware that this is a normal pattern. Knowing about it beforehand can lessen the surprise and increase the understanding of members and clergy experiencing the change from the focus on building to finding a new focus. $^{2}$

From my observations it seems to be a general practice in the Adventist church to transfer a pastor upon completion of a church-building project. This often occurs to make way for another pastor who may have strengths in evangelism and church-growth skills, so as to move the church in a new direction. Leas suggests that several tactics can be helpful to a congregation that has completed a building project. He says:

Well before the building is completed a congregation can develop leadership and visions for what will come next. Some congregations have tried their fundraising for building programs to other ministries, such as program

'Don Met, New Congregations (Philadelphia: Westminster Press, 1967), quoted in Leas, 79.

${ }^{2}$ Leas, 79 . 
development, staff development and ministry to the wider community, clarifying future ministries and developing resources and leadership for them at the beginning and as the church goes through its building phase. ${ }^{1}$

In spite of the general practice of the Adventist church to transfer pastors when completing a building project, there has been times when the pastor is given additional time to minister to the congregation in its new church building. This time will provide him the opportunity of enjoying the fruits of his labor. However, there is some merit in the assertions of Met and Leas. It may therefore be helpful for a pastor who finds himself in a building project to include plans for evangelism and church growth after the completion of the building project. By utilizing others with strengths in particular areas, he may invite them to assist him in planning strategies with his congregation. Being aware of what to expect when engaged in a building project and what to anticipate at the end of the project will provide early opportunity to meet all the challenges.

${ }^{1}$ Ibid., 79. 
CHAPTER III

PRESSURES, CONFLICTS, AND LEADERSHIP RESPONSES

Except the Lord build the house, they labor in vain that build it.

Ps 127:1

\section{Normal Pressures of a Church-Building Project}

It can be said that whenever a pastor and a congregation undertake the responsibility of constructing a church building, they will more than likely experience some degree of what I call normal physical, emotional, and financial pressure. Normal pressure can be described in this instance as varying degrees of stress and/or anxiety due to specific demands on one's time, energy, and money.

\section{Normal Physical Pressures}

During a church-building project, normal physical pressure can be anticipated by the pastor and the congregation from the preparatory stages of collecting data to the completion of the project. Working with various committees, members will be required to expend time and energy. The following list indicates ways in which time and energy will be expanded:

1. Surveying the space needs of the congregation

2. Consulting with the architect 
3. Meetings with various committees, i.e., building committee, finance committee, church board, and church business meetings

4. Reviewing design proposals

5. Developing cost projections

6. Assisting in fund-raising for the project

7. Wherever possible, actually participating in the project through their voluntary labor.

\section{Normal Emotional Pressures}

Normal emotional pressure can also be anticipated by the pastor and the congregation as they become personally involved with the project. From my experience, this type of pressure tends to grow out of one's expectations, hopes, and involvement with the project. Emotional anxiety can be generated as a result of all or some of the following reasons:

1. The speed and progress of the project (Is the project meeting its time deadlines?)

2. The way the project is being managed (How is the project being managed? Is the job on schedule? Are the architect and foreman working together in harmony?)

3. The attitude of the workers and the quality of their workmanship (Are they satisfied with their working conditions, and is there a high quality of workmanship?)

4. Money (Is there enough money to keep the project going? Will there be enough financial support to complete the project on time?) 


\section{Normal Financial Pressures}

Normal financial pressure can be expected whenever the task of constructing a church building is being undertaken by a congregation. The demands and expenditure of money for architecture services, building materials, and labor are normal for such a project. From my experience, it seems that members usually recognize their need to cut back on regular programs and be willing to sacrifice for the duration of the project.

However, holding financial pressure to normal levels can be accomplished if the following list of things is carefully planned and adhered to:

1. The projected cost of the project must fall within the financial ability of the congregation.

2. The project must stay within its projected budget.

3. There must be no last-minute hasty changes to the building plans, in respect to the extent of the excavation, and/or actual structure.

4. There must be careful management of the funds and placement of the workforce.

5. There must be no delays in providing materials to the job site, and hopefully not too much time lost owing to inclement weather.

6. There must be ongoing financial funding so that bills and workers' salaries can be paid on time.

Because normal financial pressure is so vulnerable to change and can easily fluctuate and become abnormal financial pressure and financial burden, a more detailed presentation on the subject of church financing follows in chapter 5. At this point we turn our attention to some of the building processes. The type of building process adopted by 
a church can influence the levels and kinds of pressures the congregation will likely experience.

According to Dr. Ed Streeter of Andrews University, there are at least six different types of building processes. ${ }^{1}$ For the purposes of this chapter I present only two processes which I feel embody the basic principles of all six. At the same time, they highlight some pressures that a congregation is likely to realize by adopting any one of the processes mentioned.

\section{Building Process One}

In Building Process One:

1. The church hires an architect to prepare plans and supervise construction.

2. When construction documents have been prepared, the church acts as its own general contractor, coordinating sub-contracts, purchasing materials, and securing labor.

3. Funding is received by contributions and/or lending agencies and is handled by the church treasurer.

\section{Advantages}

The advantages to Building Process One are:

1. The general contractor's profit is eliminated.

2. The church controls the quality of construction.

3. It is easier to factor volunteer labor into this building process. ${ }^{2}$

\section{${ }^{1}$ Streeter, 9.}

${ }^{2}$ Ibid. 
4. Stronger bonds of ownership, pride, and loyalty are developed by the membership.

5. The church can realize cost savings on the project.

6. The church can make a public statement to the community.

\section{Disadvantages}

The disadvantages to Building Process One are:

1. Coordinating construction work requires full-time participation of a person experienced in building. It would be difficult to retain such a person without a fee.

2. The church has no fixed maximum construction cost, only an approximation. ${ }^{1}$

3. The potential for increased pressure--physical and emotional-- is inherent.

4. Project would likely require longer time for completion.

\section{Building Process Two}

In Building Process Two:

1. The church buys a package deal.

2. The package provides plans and construction services.

3. Often financing is handled by the package as well.

\section{Advantages}

The advantages to Building Process Two are:

1. The church receives planning and construction services through a single agent.

2. The package dealer can plan and build new facilities for a fixed maximum price.

${ }^{1}$ Ibid., 8. 
3. A package deal often includes financing, further simplifying the church's role.

\section{Disadvantages}

The disadvantages to Building Process Two are:

1. The package dealer's profit is made by re-using standard plans (often with minor variations), standard materials, and standard construction. There is no guarantee that the plans or finished construction will in any way relate to church program requirements, the site, the character of the neighborhood, or climate conditions.

2. The package price is determined by what the church can bear and not on competitive bidding.

3. Since there is no agent for the church, they have very limited control over the quality of materials or equipment used in construction.

4. Most states require a registered architect's stamp on construction drawings. The architect employed acts on behalf of the package dealer and not necessarily for the owner. $^{1}$

5. The congregation can incur severe financial indebtedness.

6. Members may not feel a personal sense of accomplishment and ownership.

As an illustration of normal pressure, I cite the church-building experience I received in my early pastorate. The Somerset Adventist Church congregation and I decided to construct our own church building, utilizing the Building Process One. As a young congregation, we were blessed to have among our membership some qualified tradesmen, such as two carpenters, a master electrician, two masons, a plumber-assistant,

\footnotetext{
${ }^{1}$ Ibid., 9.
} 
and other unskilled yet willing members. From our parent Adventist church, we had access to many more tradesmen. We hired an experienced building foreman/carpenter from that congregation. Since there were no civil laws prohibiting the use of unskilled volunteer labor on a construction site, we were able to use the members who offered their services on Sundays or other work rallies. (See Appendix $\mathrm{H}$ for further reading)

From the early stages of the project, and more so as it progressed towards its completion, I made several discoveries as follows:

1. The members expected me to be present and physically involved in the work rallies. These work rallies were usually carried out on Sundays and some holidays.

2. My presence encouraged them.

3. There were financial savings as a result of the volunteer labor contributed.

4. The work rallies were physically demanding.

5. A strong bond of Christian unity and spirit of community was developed.

6. The financial pressure was minimized.

7. Men and women got involved through physical labor or the gourmet committee.

8. Spiritual growth took place. Our faith was often tested by near depletion of funds but after prayer and trust in God we witnessed financial gifts arrive into the treasury.

9. Evangelism also took place. A mason from the community who volunteered his services from the early stages of the project was baptized into the church before the project was completed.

10. The congregation was able to complete and dedicate the church without borrowing money from a lending institution. (See Appendix B and C for further reading) 


\section{Abnormal Pressures of a Church-Building Project}

Having discussed three areas of normal pressures often generated during a building project, we now turn our attention to three high-risk areas which tend to produce abnormal pressures in a building project. They are:

1. Improper procedures

2. Disproportional debt

3. Poor interpersonal relationship.

\section{Improper Procedures}

The term improper procedure is self-explanatory. In this context I am suggesting that it can result from groups or individuals in a congregation who may initiate and/or influence actions and decisions without following the accepted steps in decision-making. For example:

1. The building committee's failure to follow voted actions of the church body

2. The pastor and the foreman of the project making decisions without authorization of the Building Committee

3. The church board making decisions without consultation or recommendation from the building committee

4. Certain church members using their positions to influence the job foreman to make decisions without committee approval

5. Every member believing that he or she has the authority to make decisions in regard to the building project 
6. The pastor unilaterally making architectural changes and additions to the building plans.

In the Adventist church, it is a general policy that when the church membership is duly called into business session, it constitutes the highest authority in that local congregation. Next in line in authority is the church board: a group of individuals voted by the congregation to serve as chairpersons or directors of the various departments of the church. Next in line in authority to the church board are departmental counsels or specially appointed committees who will report to the bodies that appointed them. Improper procedures can result when a group or individuals fail to respect the lines of authority and make decisions without following the proper lines of authority. Decisions are usually processed by moving them from the line of a lower authority to a higher authority.

\section{Disproportional Debt}

Another area in which abnormal pressures can be generated is from disproportional debt. By this term, I mean financial indebtedness that is beyond the ability of the congregation to manage. This type of debt can occur if the congregation commences a building project without a carefully planned financial budget. Other factors that can influence the occurrence of disproportional debt are as follows:

1. Major alterations to the design and structure of the project, after the initial budget has been approved and the project commenced

2. Shifts in the building process originally adopted, i.e., Building Process One (a 
volunteer-labor-driven project); versus Building Process Two (a contractor-driven process)

3. A sharp decline in the financial support of the membership due to their loss of jobs, members transferring out of the church, and/or loss of morale among the membership, etc.

4. Poor project management and workmanship

5. Major structural or technical mistakes.

Disproportional debt is one of the most destructive pressures that a congregation can encounter. It has the inherent potential of discouraging the membership, creating crises in the life and ministry of the pastor, negatively impacting the progress of the project, and stifling the effectiveness and influence of the church in that community. In some instances, congregations have lost their property titles and have been forced to disband. (See Appendix K for further reading.)

Some possible solutions for dealing with a congregation experiencing disproportional debt are:

1. Pastoral transfer

2. An infusion of new church members

3. A stricter accounting of the funding and project management

4. A review of the building plans to possibly making the project smaller or building in phases

5. Increase levels of financial faithfulness on the part of the church's membership

6. Appeal to special interest groups, i.e., the Conference and/or Union for emergency financial assistance. 
The Bible gives appropriate counsel to everyone planning to engage in a church building project. In Luke 14:28-30, Jesus says:

For which of you, intending to build a tower, sitteth not down first, and counteth the cost, whether he have sufficient to finish it? Lest haply, after he hath laid the foundation, and is not able to finish it, all that behold it begin to mock him, saying, this man began to build, and was not able to finish.

\section{Poor Interpersonal Relationships}

Another area that can generate abnormal pressure during a building project is poor interpersonal relationships, primarily between the pastor and his or her congregation.

I believe it is necessary that the pastor, as leader, possess and exhibit the highest levels of interpersonal skills. It can be said that the way the pastor and the congregation interact influences the progress and results of the building project. Ideally, one might hope that poor interpersonal relationships would not exist in a church environment. However, we are a part of an imperfect world, and we are influenced by our environment, heredity, and culture. Within most congregations, there is usually a mixture of individuals from different backgrounds. The pastor and the congregation, however, must come together, adopt common goals, and share a united vision. It can be suggested that the pastor's role is crucial because he must provide guidance to galvanize his congregation in accomplishing their united task.

Warren Bennis highlights the role and challenges of a leader in his book $\underline{\mathrm{On}}$ Becoming a Leader. He says:

The study of leadership isn't really as exact as, say, the study of chemistry. For one thing, the social world isn't nearly as orderly as the physical world, nor is it as susceptible to rules. For another, people unlike solids, fluids, 
and gases, are anything but uniform and anything but predictable. ${ }^{1}$

If we analyze Bennis's statement in the context of the interpersonal relationships of a pastor and his congregation during a building project, then we might expect that both the pastor and the congregation are vulnerable for levels of conflict. But all conflict is not always bad or destructive. At times, it can be helpful and good. In his book entitled Antagonists in the Church, Kenneth Haugh says,

Conflict is a fact of life throughout society, including the church. Conflict that hones the edge of an organization and keeps it mindful of and true to its purposes is healthy. An organization with no conflict at all (and I don't know of one) must have either no purpose at all or, at best, a very frivolous purpose. $^{2}$

However, conflict as a result of poor interpersonal relationship can be detrimental to a congregation in a church project. According to Jard De Ville, "Pastoral leadership is the continuous process by which a minister tries to influence the members' attitudes and actions in order to reach specific goals." ${ }^{3}$ Good interpersonal skills are essential for the fostering of good relationships between the pastor and the congregation and, ultimately, success as they work together. 1.

${ }^{1}$ Warren Bennis, On Becoming a Leader (Reading, MA: Addison-Wesley, 1989),

${ }^{2}$ Kenneth C. Haugh, Antagonists in the Church (Minneapolis, MN: Augsburg Publishing House, 1988), 31.

${ }^{3} J a r d$ DeVille, The Pastor's Handbook on Interpersonal Relationship (Silver Spring, MD: The Ministerial Assn., General Conference SDA, 1995), 7. 


\section{Leadership Style Responses}

Whenever a pastor and a congregation engage in a project of constructing a church building, the issue of leadership style plays a vital role in the success or failure of that project. The leadership style adopted by the pastor will influence the attitude and response of the congregation. At the same time, the attitude adopted by the congregation can also impact on the leader's performance. Highlighting the issue of Christian leadership, Jard De Ville says that Christian leadership is obviously quite different from management in the secular sphere, despite some elements of similarity. In his opinion, the church in contrast with other institutions does much of its hands-on labor through the efforts of unpaid workers and it has limitations on the control of that voluntary arrangement. De Ville points out that pastors of congregations face the unique challenge of achieving their goals by offering intangible rewards to the workers. De Ville says, "What a minister has to offer fellow workers in Christ's vineyard is not a pay raise, extra holidays or prestigious promotions for diligent efforts, but a richer way of life- $-\mathrm{a}$ better way to feel about one's relationship with God, with neighbors, and with oneself."2

De Ville suggested that there are four common sources of pastoral power. Apart from that which comes from God as a spiritual source, position power and coercion power are delegated to the minister by the denomination and congregation. They create the pastor's authoritative influence over the people. On the other hand, the use of reinforcement power and performance power form his or her achievement influence, the

$$
{ }^{2} \text { Ibid., } 7 .
$$


other half of the balance. ${ }^{1}$ De Ville says:

The volunteer relationship between pastor and people puts this in a fragile setting. The pastor must work with a sophistication seldom seen in military, business, industrial and governmental organizations since these generally emphasize strong authorization and coercive power over their members. $^{2}$

\section{Authoritarian Leadership Style}

Peter Olivia suggests that there are two basic styles of approaches to leadership-three, if we include the more common mix of the basic two. He named the basic two as the authoritarian style and democratic style. ${ }^{3}$

Olivia said that the authoritarian style incorporates principles of directive behavior, focuses on the needs of the institution, and is concerned for statistics. The democratic style emphasizes non-directive behavior, focus on the person, and openness of the system. ${ }^{4}$

The supervisor [pastor] who embraces the authoritarian style is directive (ordering, prescribing, telling) in behavior, task rather than people oriented, and concerned about ... efficiency. The supervisor, [pastor] who employs democratic style is non-directive (helping, facilitating, counseling), conscious of interpersonal relations, and concerned about the human dimension of supervision [pastoring]. In practice, supervisors, [pastors] must learn to adapt the two styles to their situations. As there is a time to reap and a time to sow, there is a time to exhibit authoritarian behavior and a time to stress human relations skills. ${ }^{5}$

From Olivia's statement, we can sense the need for God's wisdom to know what

${ }^{1}$ Ibid.

${ }^{2}$ Ibid., 15.

${ }^{3}$ Peter Olivia, Supervision for Today's Schools, $4^{\text {th }}$ ed. (White Plains, NY: Longman Publishing Group, 1993), 389.

${ }^{4}$ Ibid.

${ }^{5}$ Ibid. 
type of leadership style to adopt. There is danger when a pastor exhibits too much authoritarian leadership in his congregation. This can interrupt the progress of a project and divide and weaken a congregation.

In 1900, Ellen G. White wrote an important letter which highlights the dangers of a person exhibiting too much authority and independence in a church project. She said:

Dear Brother: You will need in every move you make to know that you are moving in that way that you will not follow your own judgment, but the united advice of your brethren. You have failed in this work, working too much independently. ... You can borrow money. But have you taken your brethren right along with you in your building plans? Have you yoked up with then, and they with you? . . One man's mind and judgment is not to be allowed to become an efficiency in any case where the building of a church is concerned. It takes every member of the church who can carry responsibilities, and the minister is not the man to lift this work alone.... This is a lesson you must learn, to seek the mind and judgment of your brethren, and not advance without their advice, counsel, and cooperation. ${ }^{1}$

Robert Conklin challenges the authoritarian leadership style by saying: "To the degree you give others what they want, they will give you what you want. This is the key to persuading, leading, motivating, selling, supervising, influencing, guiding others-getting people to do things for you."2 Along with Conklin, Kouzes and Posner advocate: "You need to give people choices about what to accomplish, and how to accomplish it in order to build commitment and create ownership. Making people feel like owners is important."

${ }^{1}$ White, Counsels on Stewardship, 262. 1979), 3.

${ }^{2}$ Robert Conklin, How to Get People to Do Things (New York: Ballantine Books,

${ }^{3}$ James M. Kouzes and Barry Z. Posner, The Leadership Challenge (San Francisco: Jossey-Bass Publishers, 1987), 237. 


\section{Democratic Leadership Style}

The democratic style of leadership is perhaps the most appropriate leadership response for building a strong relationship between a pastor and a congregation. This leadership style tends to foster a sense of partnership between the leader and the group; it also cultivates a sense of team spirit and ownership. According to Kouzes and Posner,

If you've established a clear vision and have consensus and strong feelings about the right way to do things in your organization, then you've created the necessary conditions for the paradox of 'guided autonomy.' By making visible the choices that people have made, you create binding-in forces that increase the energy and drive directed at accomplishing and succeeding with the task. ${ }^{1}$

Two major components that contribute to the democratic leadership style are trust and communication.

\section{Trust}

According to Stephen Covey, "once trust is established in a congregation, it produces meaningful results." ${ }^{2}$ However, Covey warns us what can happen if there is no trust between the leader and his or her congregation. He says:

If I try to use manipulative strategies and tactics to get other people to do what I want-while my character is flawed or my competency is questionable then I can't be successful over time. Rhetoric and good intentions aside, if there is little or no trust, there is no foundation for permanent success. But if we learn to manage things and lead people, we will have the best bottom line because we will unleash the energy and talent of people. ${ }^{3}$

${ }^{1}$ Ibid.

${ }^{2}$ Stephen Covey, Principle-Centered Leadership (New York: Simon \& Schuster Pub., 1992), 17.

${ }^{3} \mathrm{Ibid}$. 
Along with Covey, Kouzes and Posner seem to echo a similar sentiment. They say, "We trust leaders when their deeds and words match."1 It is therefore necessary for any pastor leading out in a building project to carefully develop lines of trust between himself or herself and the congregation.

\section{Communication}

The second essential element in the democratic leadership style is communication. Stephen Covey says that at the root of most communication problems are perception or credibility problems. He went on to suggest that perception and credibility problems may ultimately result in complicated knots, what we often call personality conflicts or communication breakdowns. There is a suggestion by Covey that most credibility problems can be resolved if one or both of the parties involved will realize that the root is a perception problem. ${ }^{2}$ His solution to this perception problem is cited in the display of certain attitudes and behaviors that he feels are essential to clearing communication lines.

\section{Attitudes}

Under the heading of attitudes, Covey suggests that they can be displayed in at least three positive ways:

1. I assume good faith; I do not question your sincerity or your sanity.

2. I care about our relationship and want to resolve this difference in perception. Please help me to see it from your point of view.

\footnotetext{
${ }^{1}$ Kouzes and Posner, 237.

${ }^{2}$ Covey, 110 .
} 
3. I am open to influence and am prepared to change.

Behaviors

Considering the area of behavior, Covey offers three suggestive ways which can facilitate effective communication:

1. Listen to understand.

2. Speak to be understood.

3. Start dialogue from a common point of reference or point of agreement and move slowly into areas of disagreement. ${ }^{1}$

Covey seems to be of the opinion that when these three attitudes and behavior skills are acquired, almost any perception or credibility problems can be solved. He says:

Once a person changes his manner of speech; instead of saying 'this is the way it is,' he will say 'this is how I see it.' Instead of saying, 'here it is,' he will say, 'in my view. . .' or 'in my opinion. . .' or 'as I see it. .' Such language admits other people to the human race by telling them, 'you matter, too.' Like mine, your views and feelings are legitimate and respectable. $^{1}$

Along with Covey's assertions I believe it is crucial that pastors exercise care and tact when speaking to their members in general, and in particular during a building project. I have discovered that when members are spoken to in a kind and respectful manner, and made to feel a part of the decision-making process, they are usually more willing to cooperate with the proposals and decisions that have been made. De Ville reinforces this point when he says, "Effective management of communication can keep the people

${ }^{1}$ Ibid., 110. 
marching generally to the same drummer."1

\section{Act of Giving Praise and Recognition}

The act of giving praise and recognition to a congregation during a building project will complement any leadership style. If the praise is honest and the recognition fair and given to all the membership, the results of such will boost the morale and confidence of the members and the pastor.

\section{Praise}

Phillip Brooks is reported to have said, "To say 'well done' to any bit of good work is to take hold of the powers which have made the effort and strengthen them beyond our knowledge."2 Cicero wrote, "We are all excited by the love of praise."3 Robert Conklin further says that praise spurs people to achieve, gives them inner confidence, and makes them grow. He illustrates his point by sharing the following story:

A psychologist once told me, there is no mystery to raising children. Just praise them. When they eat right, praise them. When they draw a picture, praise them. When they learn to ride a bike, praise them. It has been said that one's life is spent avoiding punishment or working for rewards. Praise is a reward people work for. It shapes and stimulates behavior. ${ }^{4}$

\section{$\underline{\text { Recognition }}$}

John C. Maxwell highlights recognition as another factor that motivates people.

${ }^{1}$ DeVille, 22.

${ }^{2}$ Conklin, 47 .

${ }^{3}$ Ibid.

${ }^{4}$ Ibid. 
He says that people want to be noticed. They want credit for personal achievements and appreciation for their contributions. ${ }^{1}$ Maxwell says: "Giving recognition is another way of saying thanks. Personal accomplishment is motivating, but it is much more so when someone notices the accomplishment and gives worth to it. Recognition is one way to give meaning to a person's existence."2

Kouzes and Posner say, "Likewise, encouraging the heart--the recognition and celebration of significant accomplishment--contributes to perceptions of being just, fair and sincere." ${ }^{13}$

In light of this strategy of guiding pastors and congregations through a building project, the act of giving praise and recognition can be seen in the Bible from the words of Jesus recorded in Matt 25:21-23. Jesus says:

His lord said unto him, Well done, thou good and faithful servant: thou hast been faithful over a few things, I will make thee ruler over many things: enter thou into the joy of thy lord. He also that had received two talents came and said, Lord, thou delivered unto me two talents: behold, I have gained two other talents beside them. His lord said unto him, Well done, good and faithful servant; thou hast been faithful over a few things, I will make thee ruler over many things: enter thou into the joy of thy lord.

Whereas the pastor has the liberty to be generous to his congregation on a whole, discretion and care should always be exercised when doing so. Members who exhibit faithfulness in financial support, attendance to work rallies, and overall participation in the building project must never go unrecognized or unnoticed by the pastor. 1993), 111.

${ }^{2}$ Ibid.

${ }^{3}$ Kouzes and Posner, 25. 
Sometimes there are outstanding financial contributions or many hours of voluntary labor given by individual members, couples, or families to the church project. These persons may warrant some public recognition for their contributions. Great care should be taken to first seek their permission before doing so.

As a pastor, I discovered from three different building projects that carefully giving honest praise and recognition to the membership, had a positive effect on them, the project, and myself. It appeared to motivate the membership in accomplishing our goal and at the same time their response affirmed my leadership style. 


\section{CHAPTER IV}

\section{POLICIES PROCEDURES FOR A CHURCH-BUILDING PROJECT}

Let all things be done decently and in order (1 Cor 14:40)

\section{Policies Applicable to Bermuda Conference, the Atlantic Union. and North American Division of the General Conference of Seventh-day Adventists}

Writing on the subject of church order and organization, Ellen G. White urged that, as our numbers increased, it was evident that without some form of organization there would be great confusion, and the work would not be carried forward successfully ${ }^{1}$. She said:

To provide for the support of the ministry, for carrying the work in new fields, for protecting both the churches and the ministry from unworthy members, for holding church property, for the publication of the truth through the press, and for many other objects, organization was indispensable. ${ }^{2}$

She went on to say that there was at one time strong feelings against church organization among the early Advent believers. After earnest prayer, light was given to them by the Holy Spirit that order through discipline in the church was an essential system.

${ }^{1}$ White, Testimony to Ministers, 26.

${ }^{2}$ Ibid. 
She said: "Order is the law of heaven and it should be the law of God's people on the earth."1

One may conclude from this counsel that Ellen White was addressing the issue of corporate order and organization. Until the 1860s, Seventh-day Adventist churches were operating mainly as independent organizations. However, one might agree that it is essential for the effective functioning of any congregation to have established policies and procedures of operation as well. When a congregation decides to engage in a buildingproject, it needs to have some policies and procedures to ensure the collective input of its members in planning and in meeting the needs of the church.

Within the organizational structure of the Seventh-day Adventist Church, a decision to build a church usually begins with the local congregation and will possibly involve three higher administrative bodies. Listed in order of their authority they are:

1. The Conference Blueprint and Executive Committees

2. The Union Blueprint and Executive Committees

3. The Blueprint Committee of the North American Division of the General Conference.

The North American Division Working Policy requires that all blueprints and borrowing of funds be processed through the various committees for approval before a church commences a building-project. The policy for authorization for a building-project and its financial plans are as follows:

1. Projects exceeding $\$ 25,000$ are to be approved by the Conference Committee.

${ }^{1}$ Ibid. 
2. Projects exceeding $\$ 200,000$ are to be approved by the Union Committee.

3. Projects exceeding $\$ 500,000$ are to be approved by the General Conference Building Plans Committee and the North American Division Committee.

4. Cash requirements: The Church must have 50 percent of the entire cost of the project including initial furnishing. Land that has been paid for can be considered at cost as part of the required 50 percent of the total project.

5. Borrowed Funds: A church may be authorized to borrow up to 50 per cent of the cost of completing the project. ${ }^{1}$ (See Appendix $G$ for further reading.)

\section{Bermuda Government Building Regulations}

In every country there are usually building regulations developed by the government pertaining to the issuing of building permits and final occupancy certificates. Within Bermuda, the following regulations and procedures apply to any individual or group seeking permission to engage in a construction project. Two questions usually asked by those seeking a building permit are: Why is a building permit necessary? What is the procedure to obtain a building permit?

1. Building permits provide building officials the opportunity to protect the public against unsafe building practices.

2. The building process according to local law requires that an application for a permit be secured before any construction or remodeling work begins.

3. Building permits allow building officials the right to inspect projects to ensure

${ }^{1}$ General Conference Building Plans Committee, Suggestions to Building Planners, rev. ed. (Silver Spring, MD: General Conference of Seventh-day Adventists, 1991), 3-4. 
that minimum building standards and appropriate materials are employed in that project. ${ }^{1}$ What then is the procedure to obtaining a building permit?

1. Visit or call the Planning Department to explain what and where you desire to build.

2. Submit an application: Who, what, where, and when do you desire your work to be carried out? Sketches and drawings must accompany the application.

3. A review process at the Planning Department will consider your application. Sometimes a project will be approved in principle.

4. Receive the results of the review process: If the application to build is approved in principle or finally approved, a permit is issued. If the application is denied, there is an appeal process that can be undertaken with the Minister of Environment.

5. Receipt of a building permit grants legal permission to start construction. The number of the permit must be posted at the site in a visible location. Any changes to the approved plans must receive approval from the Planning Department before those changes can be implemented.

6. Arrange inspection visits: Those carrying out the project must ensure that inspectors are invited in at various stages of the project to provide inspection of work that has been done and work to be done. The inspectors must be notified twenty-four to fortyeight hours in advance of the required inspection.

7. Receive Certificate of Occupancy: Once the project is completed and inspectors satisfied, a Certificate of Occupancy will be issued by the Planning Department

\footnotetext{
${ }^{1}$ Building Permits: Why and How? (Hamilton, Bermuda: Department of Planning, n.d.), 2.
} 
attesting to compliances of the building code and electrical and other local safety laws. ${ }^{1}$ (See Appendix $\mathrm{N}$ for further reading.)

\section{Proposed Procedures Toward Approval of a Church-Building Project}

Let us now consider ten procedural steps for moving a building project from the local congregation to the Bermuda Government Planning Department and finally through the higher administrative levels of the church.

\section{Step 1}

After a congregation considers the idea of constructing a church building, among the first things it might do is to select a survey committee to conduct a needs assessment. After the data are collected and processed, the report and recommendations should be forwarded to the church board for their consideration and processing. (See Appendix D and $\mathrm{E}$ for further reading.)

\section{Step 2}

After the church board has reviewed the report and recommendations, and if it deems the building project feasible, its recommendation will then be forwarded to the congregation in a duly called business session.

\section{$\underline{\operatorname{Step} 3}$}

If the congregation in business session accepts the report and recommendation to build a church, it will then adopt the report for action and implementation. At this point,

${ }^{1}$ Ibid. 
the church body may authorize the church board or select a building committee to process preliminary drawings and final finished plans. It would be appropriate also at this time for a finance committee to be selected to make a preliminary assessment of the financial capacity of the congregation (see chapter 5 for more information of this assessment). Establishing the financial capacity of the congregation early in the planning stages of a building project can be of great assistance in determining the time and size of the project. At this point, it will be appropriate to notify the Conference administration of the action of the church body.

\section{Step 4}

The building committee in consultation with the church board may select an architect. Once the architect is selected, then together with the building committee they will produce preliminary drawings incorporating the needs of the church as understood from the survey assessment study.

\section{$\underline{\text { Step } 5}$}

Once the building committee is satisfied with the preliminary drawings, a preliminary cost projection can be developed. When both the drawings and the cost projections are completed, they can be presented to the church board with recommendations. From the church board, the drawings and the cost projections will then be presented to the congregation in business session. If the congregation in business session accepts the preliminary drawings and financial plan, then the drawings can be sent to the Planning Department for its approval in principle. 


\section{Step 6}

Upon receipt of approval in principle from the Planning Department for the preliminary drawings, the architect can then be authorized to produce working or finished drawings. At this point, all other building disciplines such as the steel and electrical and mechanical engineers will be selected by the building committee in consultation with the architect and ratified by the church board. They can then be called upon to have input in producing the finished or working drawings.

\section{Step 7}

Upon completion of the working or finished drawings, a second financial cost plan can be formulated. After careful examination by the building committee, both the finished drawings and the financial plan can then be presented to the church board for its approval and recommendation to the church body in business session for final approval and adoption.

\section{Step 8}

Upon receipt of the congregation's final approval of both plans, the architect can then be authorized to submit the building plans to the Planning Department for its final approval and issuing of a building permit. Until an official building permit and a number has been issued by the Planning Department, no work on the proposed building can legally take place, such as removal of soil, rubble, or stone.

\section{$\underline{\text { Step } 9}$}

After the church plans have received their final approval from the Planning 
Department, both the working/finished plans and the financial plans should be submitted to the local Conference Blueprint and Executive Committee. Upon receipt and approval from the local Conference committees, depending on the cost of the project, as discussed above, the next step may require that the plans be sent to the Union Blueprint and Executive Committee and/or possibly on to the Division Blueprint Committee. During this period, no work on the structural site should commence until all church administrative approvals have been received. When all approvals have been received, an official groundbreaking ceremony may be held to officially launch the building project. This would include inviting the Conference administration, guests from the community, and other supporters of the project.

$\underline{\text { Step } 10}$

Once the actual building project commences, it would be appropriate to set up a separate financial accounting system to manage and track the project's funding. If at all possible, an individual other than the local church treasurer can be selected to manage the accounts of the project. This person/s would receive money from the church treasurer, then disburse these monies to pay various entities involved in the building project such as workers' salaries and allowances, payment to suppliers for materials, and any other expenses related to the project. Regular monthly financial reports should be made to the building committee, to the church board, and to the church membership at regular business meetings. It would be appropriate to keep the local Conference administration informed about the development and expenditure of the project as well. 


\section{The Building Committee and Its Role}

The work of the building committee is essential, and, as a result, a standing committee is recommended. According to Robert Carr,

The proper function of a building committee is not to design a church, but to set the ground rules and approve of many of the large decisions. The task is simply to determine the architect, contractor (with the architect's guidance), general budget, type of facilities, size specifications, and the type of styling wished by all in general. ${ }^{1}$

Carr suggested that before the architect is commissioned, the committee should spend the majority of its time composing a list of specifications that coincides with the church's doctrine and criteria cited earlier. ${ }^{2}$ (See Appendix I for further reading)

Once the committee has formulated the list of specifications and limitations both physically and aesthetically, a qualified architect and a designer should be commissioned to take over, at which time the committee can rest a while. If these professionals are skilled they will present a plan that will most likely serve the congregation in every need and desire. ${ }^{3}$

However, Carr cautions against the pastor of the church serving as the chairman of the building committee. He contends that the pastor should pastor and be a part of that committee and not the chairman because the pastor has enough responsibility meeting the needs of his/her congregation. ${ }^{4}$

While I agree with some of Carr's statements concerning the role and position of majority of its time composing a list of specifications that coincides with the church's

${ }^{1}$ Carr, 79.

${ }^{2}$ Ibid., 80.

${ }^{3}$ Tbid.

${ }^{4} I b i d ., 81$. 
doctrine and criteria cited earlier. ${ }^{1}$ (See Appendix I for further reading.)

Once the committee has formulated the list of specifications and limitations both physically and aesthetically, a qualified architect and a designer should be commissioned to take over, at which time the committee can rest a while. If these professionals are skilled they will present a plan that will most likely serve the congregation in every need and desire. ${ }^{2}$

However, Carr cautions against the pastor of the church serving as the chairman of the building committee. He contends that the pastor should pastor and be a part of that committee and not the chairman because the pastor has enough responsibility meeting the needs of his/her congregation. ${ }^{3}$

While I agree with some of Carr's statements concerning the role and position of the pastor, however I suggest that there may be times when the pastor of the church is the appropriate person to serve as the chairman of the building committee. My reasons are as follows:

1. The pastor may have had previous church-building experience.

2. The pastor will have flexible time, thereby allowing accessibility for consultation with the architect, suppliers, and other building disciplines.

3. The pastor's knowledge of parliamentary procedure can ensure that all steps and procedures are followed correctly and that there is collective input.

4. The pastor's ability to represent the church to suppliers and other government officials can be of influence to the church's project.

${ }^{1}$ Ibid., 80.

${ }^{2}$ Ibid.

${ }^{3}$ Ibid., 81 . 
5. The pastor's involvement with the project can be an incentive to the rest of the membership.

Among the many things that a pastor should keep in mind during a building project--whether he or she is the chairperson of the building committee or a member--is that the building project belongs to the membership of the church. Therefore, the collective input of the members must be encouraged all the time. 


\section{CHAPTER V}

\section{FINANCING AND FUNDING A CHURCH-BUILDING PROJECT}

Counsel from Ellen G. White has been foremost in helping to shape the attitude and practice of financing and fund-raising for Seventh-day Adventist building projects.

\section{Concepts and Principles of Church Funding}

In 1886, Ellen G. White appealed for a humble house of worship. She believed that we have no command from God to erect a building that will compare for richness and splendor with the temple. But we are to build a humble house of worship, plain and simple, neat and perfect in its design. ${ }^{1}$ She went on to urge the following:

1. Those who have means should be liberal with those means and they should erect tasteful buildings to God.

2. There should be a willingness and desire to show great honor to God by tastefully furnishing the church as they furnish their own homes.

3. There should not be extravagance in building the house of God, however, God's house should be built conveniently and thoroughly so that when it is presented to God it can be accepted by Him, and His spirit will rest on the worshippers who have a eye single to His glory.

'White, "Building a House for God." 
5. Nothing must interfere between God's glory and us, no selfish plans, no selfish schemes, no selfish purposes. ${ }^{1}$

In 1887, Mrs. White had reason to caution a congregation in California against investing more means in buildings. She feared the church would overextend itself and thereby create an imbalance in its financial position. ${ }^{2}$ Although she was writing to a specific situation, the value of her counsel can be applied to anyone today who engages in financial outlays.

In 1905, Ellen White wrote, "In laying plans for building, we need the wisdom of God. We should not needlessly incur debt, but I would say that in every case all the money required to complete a building need not be in hand before the work is begun. We must often move forward by faith working as expeditiously as possible."3

In summarizing a great deal of Ellen White's counsel on church expense, Carr points out:

[The] Seventh-day Adventist viewpoint of temperance is expressed by Ellen White who points out that temperance should be practiced in all aspects of life; in architecture, it is not the expensive building that gives character to the work of the church, but it is the cooperative spirit manifested by the members. In designing a house for God, priority should be given to order, functionality, neatness and 'plain beauty.' Expenditures of large sums of money do not necessarily produce a church which is beautiful and functional. Church members are to be temperate in all things, including diet, dress, and economy. ${ }^{4}$

\section{${ }^{1}$ Ibid.}

${ }^{2}$ Ellen G. White, "Guard Against Unwarranted Expense," MS 23, 1886, E. G. White Research Center, Andrews University, Berrien Springs, MI.

${ }^{3}$ White, Counsels on Stewardship, 280.

${ }^{4}$ E. G. White, "Honor the Lord with Thy Substance," Youth's Instructor, 26 August 1897, 266, quoted in Carr, 18. 
He went on to emphasize that outward show and a large outlay of means are not necessary in order to gain the blessing of God. Human taste, human devising, and human inclination to ornament are not to be encouraged. An unnecessary expenditure of money means that there will be less to invest in the work in other places. An appearance of wealth or position, an expensive architect or furnishing are not essential to the advancement of the work of God, neither can achievements that win applause from men and administer to vanity. ${ }^{1}$

It is evident from the counsel from E. G. White that financing a church-building project will require God's wisdom and the faith and willingness of each member to share his/her personal means. In addition to funding a project this way, Mrs. White suggests that funding for a building project may be solicited from larger Adventist churches. She writes:

Let the larger churches which are free from debt, come to the help of their sister churches, and give of their intrusted means toward these smaller places of worship, that the small churches may not be oppressed and discouraged under a load of debt. Let us not like the priest and the Levite pass by on the other side. What blessings would be meted out to the churches that help in this way and what love on the part of the poorer churches, as they realized that they were watched over for good. ${ }^{2}$

On the related subject of borrowing money for church buildings, Mrs. White says, "The fund raising strategy that is given by inspiration is as follows: Local members give sacrificially and provide labor with their hands, sister churches give assistance, and then as

${ }^{1}$ Ibid., 19. $1891,450$.

${ }^{2}$ Ellen G. White, "Larger Churches Helping Smaller," Review \& Herald, July 21, 
a last resort, funds can be borrowed at the best terms possible and paid off as quickly as possible."1

\section{Do's and Don'ts of Fund-Raising and Funding for Church-Building Project}

In view of Ellen White's counsel, let us consider some do's and don'ts of fundraising and funding for church-building projects.

In the Bermuda Conference of Seventh-day Adventists, the Conference policy allows new church-building projects to receive as Conference appropriations up to 10 percent of their projected finished cost, depending on the availability of funds. This amount is usually spread over a two/three-year period of time, over which time most Adventist buildings in Bermuda are constructed. The remainder of the funding is usually left to the local church to raise through sacrificial giving, soliciting from friends, or borrowing.

The Lutheran Synod Statement says:

Responsible stewardship in the work of the church demands that much of the construction funds be obtained from the local source-the congregation. The amount available in the form of pledges and contributions should be determined prior to any commitment from outside sources. ${ }^{2}$

Ellen White admonishes: "We see the churches of our day encouraging feasting, gluttony, and dissipation, by the suppers, fairs, dances, and festivals gotten up for the purpose of gathering means into the church treasury. Here is a method invented by carnal

${ }^{1}$ White, Counsels on Stewardship, 280.

${ }^{2}$ The Lutheran Church--Missouri Synod, Architectural Guide: For Worship and Education, rev. ed. (St. Louis, MO: Commission on Architecture, 1978), 23. 
minds to secure means without sacrificing."1

She goes on to say that, when money is raised for religious purposes to what means do churches resort? To bazaars, suppers, fancy fairs, even to lotteries and like devices. Often the place set apart for God's worship is desecrated by feasting and drinking, buying, selling, and merry making. ${ }^{2}$ She believed that respect for the house of God and reverence for His worship are lessened in the minds of the youth. She suggested that barriers of self-restraint are weakened; selfishness, appetite, and the love of display are appealed to and strengthened as they are indulged. Mrs. White questioned the impression made upon the minds of unbelievers. She says, "The holy standard of the Word of God is lowered into the dust. Contempt is cast upon God and upon the Christian name." ${ }^{.3}$ She further states:

The most corrupt principles are strengthened by this un-scriptural way of raising means. And this is as Satan would have it. Men are repeating the sin of Nadab and Abihu. They are using common instead of sacred fire in the service of God. The Lord accepts no such offerings. All these methods for bringing money into His treasury are an abomination to Him. ${ }^{4}$

The question sometimes arises about the use of tithe. According to the General Conference Working Policy, tithe should not be used for:

1. Capital expenditures for buildings and facilities

2. Equipment 289.

${ }^{1}$ Ellen G. White, Welfare Ministry (Washington, DC: Review and Herald, 1952),

${ }^{2}$ Ibid., 290.

${ }^{3} \mathrm{Ibid}$.

${ }^{4}$ Ibid. 
3. Local church operating expense

4. School operating expenses. ${ }^{1}$

Ellen G. White advocated that the plan of Moses in the wilderness to raise means was highly successful. There was no compulsion necessary. Moses made no grand feast. He did not invite the people to a scene of gaiety, dancing, and general amusement. Neither did he institute lotteries or anything of this profane order to obtain means to erect the tabernacle of God in the wilderness. ${ }^{2}$

God commanded Moses to invite the children of Israel to bring the offerings. Moses was to accept gifts of every man that gave willingly from his heart. These freewill offerings came in so great abundance that Moses proclaimed it was enough. They must cease their presents, for they had given abundantly, more than they could use. ${ }^{3}$

Most congregations in the Bermuda Conference engaged in building projects provide opportunity for their members to contribute their means and their labor.

Oftentimes as a last resort they will borrow money from a bank. In my opinion we should do everything to keep our fund-raising methods for church projects in harmony with the counsel we have received from Ellen White and the examples given in the Bible. (See Appendix $\mathbf{P}$ for further reading.)

\section{The Finance Committee and Its Role}

The congregation faced with the task of obtaining funds may start the process by

${ }^{1}$ General Conference of Seventh-day Adventists, Working Policy of the General Conference of Seventh-day Adventists (Washington, DC: Review and Herald, 19951996), 542-543.

${ }^{2}$ White, Welfare Ministry, 291.

${ }^{3}$ Ibid., 292. 
organizing a finance committee to develop a funding plan for the project. Their research should answer the following questions: What is a realistic estimate of the amount of money the congregation will be able to raise within an allotted time? What amount of debt will the congregation be able to carry without impairing other church activities? What amount of money can be raised through memorials for planned building programs?

According to The Lutheran Synod, the role and function of the finance committee is to determine the realistic debt limit of the congregation. The building needs or the projected program may exceed the financial ability of the congregation, and the finance committee will be required to make this clear to the members. The committee must properly evaluate the ability of the congregation to make payments on the anticipated debt while carrying on its other programs. A congregation obligated to make payments beyond its ability places the rest of the church's programs into jeopardy. Only intensive study will develop the proper debt limits, and the finance committee should be prepared to invest the required time. $^{1}$

\section{Assessing the Financial Strength of the Congregation}

The following types of assessment can be employed to determine the financial strength of a congregation.

\section{Assessment I}

According to the Lutheran Church-Missouri Synod Architectural Guide, "The amount of money the congregation can raise and the amount of debt it can efficiently carry

${ }^{1}$ Lutheran Church--Missouri Synod, 30. 
can be determined by survey, analysis, and counsel."1

In Step 1, make a statistical survey of the congregation's financial status. The survey should include:

1. Tabulation of congregation's past financial performance (both budget and actual)

2. Tabulation of congregation's current financial performance

3. Projection of anticipated financial performance (including needs, debt repayment, and inflation)

4. Tabulation of congregation's debt record

5. Appraisal of value of congregation's land and improvements

6. Status of title of congregation's property

7. Congregation's past numerical growth

8. Congregation's projected numerical growth. ${ }^{2}$

For Step 2, investigate all available sources of construction funds including:

1. Funds available from the membership in form of contributions, pledges, and the value of volunteer labor

2. Bank loans

3. Appropriations from higher organizations.

\section{Assessment II}

Another method of assessing the financial strength of an Adventist congregation is

${ }^{1}$ Ibid.

${ }^{2}$ Ibid., 22. 
to survey its tithing pattern over a given period of time. The tithe usually reflects 10 per cent of the members' income. This can provide an idea as to the quantity of money the membership earns. With this information we can have an understanding of the potential ability of the congregation to carry indebtedness.

Closely associated with the tithing system in the Adventist church is the program of systematic benevolence. This is an additional amount of money given on a regular basis to support the local church's combined budget. It has been suggested that the average operational combined budget of a church is approximately 8 percent equivalent of that church's tithe. If during a building project the church members were to systematically contribute the equivalent of a second tithe, the church's operational budget should then sustain their special needs. A breakdown of the two percentages is presented in table 2 .

TABLE 2

TWO TITHING PLANS COMPARED

\begin{tabular}{|l|l|}
\hline \multicolumn{1}{|c|}{ Plan 1 } & \multicolumn{1}{c|}{ Plan 2 } \\
\hline Tithes - 10\% plus $8 \%$ & Tithes - 10\% plus 10\% \\
\hline World Mission - 2\% & World Mission - $2 \%$ \\
\hline Conference Development - 2\% & Conference Development - 2\% \\
\hline Combined Budget - $2 \%$ & Combined Budget - 3\% \\
\hline Church Building - $2 \%$ & Church Building $3 \%$ \\
\hline GRAND TOTAL - $18 \%$ & GRAND TOTAL - 20\% \\
\hline
\end{tabular}




\section{Assessment III}

Another method of discovering the church's financial ability is through the development of two financial ratios:

1. Liquidity or Current Ratio and

2. The Debt Ratio.

The Liquidity Ratio or Current Ratio can result from Current Assets divided by Current Liabilities. The Liquidity or Current Ratio indicates the ability of an entity to cover its current liabilities (obligations). Reading the results will be as follows:

The higher the result, the stronger the financial position of the entity. A one-toone ( 1 to 1 ) ratio meaning $\$ 1.00$ asset to $\$ 1.00$ liability indicates that the organization has just enough income to meet its expenses. The ratio will determine the amount of monthly payments the congregation can manage.

The Debt Ratio is measured by finding the percentage of total liabilities to assets:

Total Assets ${ }^{1}$ x 100 divided by Total Liabilities. ${ }^{2}$

If the result is 50 per cent or above then the entity is not in a good financial position to incur new debts. The lower the percentage, the better the financial position of the entity. The ratio will determine how much debt the church will be able to incur.

\section{Congregational Commitment to a Finished Building Project}

Before concluding this chapter, we turn our attention to the spiritual and

${ }^{1}$ Assets: Cash in hand, saving, land value, investment, special appropriation from higher administration.

${ }^{2}$ Liabilities: accounts payable, loans, and outstanding debts. 
psychological approaches which can be used to encourage commitment among the membership toward a finished building project. When a congregation has decided to enter into a building program, it has committed itself to participate in a step that will have farreaching effects on its life and mission. The Lutheran Church--Missouri Synod statement says: "A building program has lasting effect, one which will have an impact on all of the organized components of the congregation for many years to come."1

The level of support shown by the pastor and the congregation to the building project will be a public testimony of their faith and commitment to God to the commission of Jesus Christ and the mission of the church. This testimony can be a witness to the community around them. It is essential that the pastor recognize that the commitment of the congregation is something that can be nurtured and encouraged. One way to accomplish this goal is through the means of preaching before and during a churchbuilding project. The pastor may want to develop a series of sermons around the general theme of building a house of worship for God. Some scriptural passages and suggestive titles listed below may help to cultivate a spiritual environment in which the Holy Spirit can impress the hearts and minds of the members, and the pastor himself toward exhibiting love, faith, and commitment for a finished work.

1. Exod 25:8--"Let them make me a sanctuary" (a call to build a house for God)

2. Ps 127:1--"Partners with God" (a call to recognize that God is willing to go into partnership with us)

\footnotetext{
${ }^{1}$ Lutheran Church--Missouri Synod, 17.
} 
3. Matt 17:20, 21--"Small Faith vs. Big Work" (a call to highlight the amount of faith we need to be successful for God)

4. Mark 11:22-24--"Faith that Works" (a call to put faith into action and exhibit trust and confidence in the promises of Jesus)

5. Acts 7:48-50--_What kind of house will you build Me?" (a call to recognize where God dwells, yet He is willing to dwell with those who love Him)

6. 1 Chr 17:1-2--“What kind of house does God deserve?" (a call to recognize that God's house deserves the best materials that we can give Him)

7. 1 Kgs 6:9--"The unfinished church" (a call to commitment to finish the project)

8. 1 Kgs 9:3--“God's consecrated house" (a call to accept God's promises and His relationship to His house of worship)

9. 1 Chr 22:2-5--"Building for the King" (a call to recognize the kinds of materials used in the Lord's house)

10. $1 \mathrm{Chr} 22: 15-16-$-“Workmanship that counts" (a call to diligence and acceptable workmanship/emphasis on quality of workmanship for the Lord's house)

11. Eph 2:19-22--"Laying the cornerstone" (a call to let Jesus be the Cornerstone in our lives, as the cornerstone of the physical building is essential to the strength of its structure)

12. Ps 118:22-24--"The stone the builders rejected" (a call to the membership against rejecting the opportunity of personal involvement in the building project as well as the benefits of involvement can in type symbolize the benefits of the stone needed for the corner of the structure).

Many presentations or seminars on church-building can be developed from the 
Bible, the writings of Ellen G. White and other materials on church projects. These presentations or seminars can be given at prayer meetings, divine worship times or specially called gatherings. Out of the many Biblical references to constructing places of worship, two whole books of the Bible rich in stories and experiences of temple/church construction are the books of Ezra and Nehemiah. Share the call and challenge of Ezra, in rebuilding the temple in Jerusalem, Ezra 1-10, or the struggles and final success of Nehemiah in the rebuilding of the walls of Jerusalem, Neh 1-13. Consider Moses' appeal to the children of Israel for money, and their response, Exod 35-40 (module of fundraising). Then reflect on God's response to faithfulness, 1 Kgs 9:3.

In addition, testimonies about answered prayers experienced by the members or the pastor as a result of their sacrifice and personal involvement with the building project can be useful in building faith and motivation for the project as well. Answered prayers may be shared from the following experiences:

1. A member's prayers for a job so that he/she could be in a position to contribute to the building project

2. Members' prayers for a certain quantity of money by a specific time for the project and having their prayer answered

3. Members' prayers for a prospective donor's contribution of money, supplies, or volunteer labor and their request being answered.

In nurturing the spirit of commitment among the membership, the pastor plays a key role. He must at all times exhibit a trusting attitude and sense of commitment to God and the project as well. He needs to stay close to the congregation during this time. When the congregation sees the pastor personally involved and committed, this will 
strengthen their confidence in the project and his leadership.

Building the spirit of commitment among the members can also be fostered by their realization of the privilege they have to construct a dwelling place for the presence of

God. A sermon centered on David's desire to build a temple for God and God's decision to deny his request may cultivate within members the recognition of the privilege they have to construct a house of honor and worship for God (1 Chr 17:4, 11-12).

A final step that can enhance the spirit of commitment is for the members to periodically rededicate themselves to God and the task of completing His house of worship. Sermons centered around texts such as Rom 12:1 and 1 Pet 2:1-5 can be used to call attention to the availability of the power of the Holy Spirit to reconstruct our human lives and empower us to accomplish all things for God's glory.

There are psychological factors associated with a building project that can also have a direct influence on the morale and motivation of the members to complete the building task. I have observed that when presenting a proposed church project to the church members, instead of constantly presenting it in terms of its total costs and total structure, dividing the project into stages and smaller cost units positively impacted the congregation. Approaching the project in smaller segments provided the congregation the opportunity of achieving early success in both fund-raising and in structural development. For example, by focusing on the project's foundation and its cost as a first step, or on laying the first floor as a second step, or windows, or the doors, and so on, with each segment's cost the congregation can see targets that are reachable. These targets set in a time frame provide the congregation with something to work for. Every time they achieve success in both raising the funds and completing the structural 
development, they are motivated to strive for the next stage of the building development. Upon completion of each phase or segment, hosting a celebration and giving recognition to God also inspires motivation toward completing the next segment. I have observed the overall effect of this approach on the members of the Somerset Church and was a part of their successful completion and dedication of their church building, which was constructed without their borrowing money from a bank or lending institution.

Church-building projects are usually perceived in a different way than other secular building projects. And for this reason there is a greater tendency on the part of church members to accept the responsibility and obligation of completing a house that will be used for God's worship and His glory. 


\title{
CHAPTER VI
}

\section{CONCLUSIONS, IMPLICATIONS, AND RECOMMENDATIONS}

\author{
Creativity is bringing into \\ birth some new reality
}

Plato

In concluding this strategy for guiding pastors and congregations through a church- building project, I borrow sentiments from Dr. Edward Streeter, a professor at Andrews University. He says that Adventist facility planners, whether they be clergy or educators, are having to cope with an ever-increasing complex of issues and needs. ${ }^{1}$

The pressures of an expanding organization, the problems of updating existing facilities, along with the desire to accommodate all the constituency - adults and children - in adequate facilities, are presenting a challenge that is unique and staggering. Tens of millions of dollars are being spent annually in building or modernizing schools and churches. ${ }^{2}$

Streeter was also of the opinion that effective facility planning cannot be accomplished in isolation. The combined resources of the church organization must be effectively utilized in the planning process. The good functional church buildings do not happen, they must be planned. ${ }^{3}$
${ }^{1}$ Streeter, 1.
${ }^{2}$ Ibid
${ }^{3}$ Ibid. 
In agreement along with Dr. Streeter, I present in conclusion the following summary:

1. A pastor and congregation contemplating a church-building project need to give careful attention and planning as to meet the needs of their membership and provide assistance to the communities in which they are located.

2. In a church-building project there should be collective decision-making among the members.

3. In a church-building project intentional efforts should be made to merge the church's architecture with the congregation's theology, worship practice and mission.

4. Careful attention needs to be given to educate the church members concerning fund-raising and funding of church-building projects.

5. Good functional churches must be carefully planned.

\section{Implications}

Understanding the power of nonverbal communication, the Seventh-day Adventist Church has historically incorporated in its architectural design features that are consistent with both their theology and working practice. According to Robert Carr, Carl Droppers suggests that Adventists should build to proclaim the advent of Christ in a nonverbal way just as they proclaim the seventh day for worship in a non-verbal way simply by church attendance on that day. On another teaching of the church, that of baptism by immersion, Droppers suggested that the way Adventists relate to the baptistry is of interest. He observed that the constant physical representation of the baptistry is a constant reminder to the members throughout the year. He says, "Instead of hiding the baptistery behind 
curtains on a distant wall, place it near the congregation with no disguise as to its use. Perhaps allowing water to be seen and heard would have a positive psychological effect on people's minds."1

The observations of Dropper certainly provide the opportunity for the Adventist church to be affirmed in its trend of building churches as flexible buildings, designed to accomplish the mission and religious practices of the congregation. However, the point has been reinforced that nonverbal language can play a major role in communicating the theology of a church. It is necessary and important that the Adventist church maintain the various areas that it has held as significant and important in its church constructions. Constructing buildings in a nonextravagant and yet elegant way can surely portray our belief in the soon return of Jesus Christ, and making the baptistry more visible can proclaim the importance of baptism by immersion. Finally, providing Sabbath School classrooms, administrative areas and fellowship hall, and other areas for youth activity will allow the church to be in a position to minister to the needs of all its members and the secular communities in which they are located.

\section{$\underline{\text { Recommendations }}$}

As the Adventist church continues to engage in soul winning, the need to provide its membership with centers of worship will be ongoing. In anticipation of continual needs, this dissertation has been written. It has not been written to provide the standard pattern for church architectural design. Rather, its primary purpose has been to correlate principles of design and theology with a strategy which will assist pastor and

${ }^{1}$ Carr, 82-83. 
congregations in developing new churches to meet the demands and needs of their increasing memberships.

The following recommendations are therefore given in the hope that pastors and congregations will have in one single document an available source of information related to constructing a church building.

1. The Seventh-day Adventist Church needs to provide more education and information to its members as to the reasons for their differences in their liturgical functions, furniture placement, and secondary rooms as they relate to other Protestant churches.

2. Pastor and congregations need to keep in mind that a church's architectural design has the ability to articulate its theology and mission through nonverbal communication.

3. Architectural designs in Adventist churches should not be built extravagantly or lavishly but rather with simplicity and elegance.

4. Seventh-day Adventists need to maintain their uniqueness in their liturgical practices, furniture placement in the sanctuary, development of secondary rooms, and their concept of appropriate uses of the church building.

5. Adventists need to make provisions in their church structures to accommodate an increasing aging and handicapped membership.

6. Adventist churches should comply with the church's building policies.

7. Adventist churches engaging in a church-building project should comply with the church's policy on fund-raising and the funding of new church buildings.

8. In selecting a site/location for a new church building, pastors and 
congregations should keep in mind that the accessibility of the place for members and visitors is crucial.

9. During and after construction of a church building, adequate insurance and a maintenance program must be implemented.

10. Adventist church buildings should be designed and equipped so as to provide regular use for the membership and community throughout the week.

11. The acoustical environment of an Adventist church should be designed in a way to minimize sound absorbing materials and provide an acoustical environment constructed to enhance natural and instrumental projection of sound. This will encourage congregational singing and an easy listening atmosphere. 
APPENDIX 
APPENDIX A

CHURCH-BUILDING SEMINAR 
Announcement of Seminar

\section{A SEMINAR OF NEW CHURCH-BUILDINGS}

New church-buildings: Should Adventist congregations be involved in such projects in these times of earth's history?

If we are, then what should they look like? Can a building communicate a church's theology and vision. Should Adventist structures be different from other Christian churchbuildings? How can a congregation accomplish the task of building a church?

Come and be a part of this seminar.

$\begin{array}{ll}\text { PLACE: } & \text { St. George's S.D.A. Fellowship Hall } \\ \text { DATE: } & \text { September } 27,1997 \\ \text { TIME: } & 3: 30 \text { p.m. }\end{array}$

PRESENTER: $\quad$ Pastor Carlyle C. Simmons, a Doctor of Ministry candidate of Andrews University Theological Seminary. This project is associated with his D.Min. Project: A Strategy for Guiding a Pastor and Congregation Through A Church Building Project.

\section{Seminar Qutline}

1. Rationale for a Church Project

a. Christ's commission to the church to go and preach - Matthew 28:18-20; Revelation 14:6-12.

b. The extent and effectiveness of the Adventist Church in fulfilling the Commission of Jesus,

1. Church growth statistics, for membership and the numbers of Church-buildings. 
2. Projection in church growth - the need for more churches

3. Counsel from Ellen White to build churches to fulfill mission.

2. Church-Building Design Impact and Theology

a. Church-Building's Architecture and Design: How Does It

Communicate.

b. Short History of the Development of Church-Building during the First Century AD

c. Origin and Development of some Dominant Church Architectural Feature and Design

d. Influence of Church Architecture on Liturgy

e. Bermudian Churches Architecture and Design

f. Seventh-day Adventist Church's Theology, Liturgy, and Architecture

g. Concept of Church

1. A call for flexibility

2. The pulpit: Its role, function and location

3. Usages of the sanctuary area

4. The Baptistry and the Communion Table

5. Musical Instruments and Choir

6. Usages of Adventist Church-Buildings

7. A call to maintain unique Adventist practices

8. Criteria for judging Adventist churches in light of its theology

9. Development of Secondary Rooms

a. Church's Main Entrance/Narthex

b. Classrooms for Study and Teaching

c. Fellowship Hall

d. Kitchen Area

e. Administrative and Stewardship: The Office Area

10. Adventist Church Design

11. Church Location/Site

12. Church Maintenance and Insurance

13. A New Building /A New Beginning

3. Pressures, Conflicts, and Leadership Responses

a. Pressures in a Building Project

b. Normal Pressures of a Church-Building Project

1. Physical

2. Emotional

3. Financial

c. Abnormal Pressures of a Church-Building Project

1. Improper procedures

2. Disproportional debt

3. Poor Interpersonal Relationships

d. Leadership Styles and Responses

1. Authoritarian Leadership Style 
2. Democratic Leadership Style

e. Act of Giving Praise and Recognition

4. Policies and Procedures for Church-Building Projects

a. Policies Applicable to Bermuda Conference, Atlantic Union, and North American Division of the General Conference of Seventh-day Adventists

b. Bermuda Government Building Regulations

c. Proposed Steps and Procedures Towards Approval of a ChurchBuilding Project.

d. The Building Committee and Its Role

5. Financing and Funding a Church-Building Project

a. Concepts and Principles for Church Funding

b. Do's and Don'ts of Fund-raising and Funding

c. The Finance Committee and Its Role

d. Assessing the Financial Strength of the Congregation

1. Assessment I

2. Assessment II

3. Assessment III

6. Congregational Commitment to a Finished Building Project

a. Nurturing the commitment

b. Sermon themes during a building project

c. Understanding the privilege

7. Appendix One and Two - Summaries of Two Bermuda Church Projects to be verbally shared during the presentation of the seminar.

a. First building project

b. Dynamics involved in razing an old church and building a new church

8. Summary

a. Conclusions, Implications, Recommendations

b. Post Seminar Evaluation 


\section{Seminar Evaluation Form}

The members were asked to circle the appropriate letter:

1. What is your current position?

a. Church Member

b. Conference Worker

2. What is your age category?

a. $12-20 \mathrm{yrs}$

b. $21-45 \mathrm{yrs}$

c. 46 and over

3. Did you have questions about church construction before this seminar?
a. Yes
b. No

4. Did the seminar answer your questions?

a. Yes

b. No

c. Partially

5. Rate your response according to the following number:

\begin{tabular}{|l|lcccc|}
\hline & $\begin{array}{l}\text { Strongly } \\
\text { Agree }\end{array}$ & Agree & $\begin{array}{c}\text { No } \\
\text { Opinion }\end{array}$ & Disagree & $\begin{array}{l}\text { Strongly } \\
\text { Disagree }\end{array}$ \\
\hline $\begin{array}{l}\text { a. This seminar had an } \\
\text { adequate Biblical base }\end{array}$ & 1 & 2 & 3 & 4 & 5 \\
\hline $\begin{array}{l}\text { b. The subject matter was } \\
\text { clearly presented }\end{array}$ & 1 & 2 & 3 & 4 & 5 \\
\hline $\begin{array}{l}\text { c. Practical information was } \\
\text { given for a congregation and } \\
\text { pastor }\end{array}$ & 1 & 2 & 3 & 4 & 5 \\
\hline $\begin{array}{l}\text { d. The presenter } \\
\text { demonstrated an adequate } \\
\text { knowledge of church- } \\
\text { buildings }\end{array}$ & 1 & 2 & 3 & 4 & 5 \\
\hline $\begin{array}{l}\text { e. I am more informed about } \\
\text { church-buildings now than } \\
\text { before the seminar }\end{array}$ & 1 & & & & \\
\hline $\begin{array}{l}\text { f. I found the seminar } \\
\text { inspirational, helpful, and } \\
\text { productive }\end{array}$ & 1 & 2 & 3 & 4 & 5 \\
\hline
\end{tabular}

6. Circle the letter for the area(s) which you found most useful:

a. Biblical rationale for church-building projects

b. Church Architecture and Design/Communication

c. Short history of the development of church-buildings 
d. Origin and development of some dominant church architectural features and design

e. Influences of church architectural design on liturgy

f. Bermudian churches architecture and design

g. Seventh-day Adventist Church Theology, Liturgy, and Architecture

7. Which section did you find least useful?

$$
\text { Why? }
$$

8. List things you would consider necessary for a future presentation on this subject.

\section{Reports and Results of Seminar Conducted}

On September 27, 1997 a church-building seminar was conducted at the St.

George's S.D.A. Fellowship Hall, in which thirty members attended. Most of these members make-up the newly formed St. David's S.D.A. Church which was organized on October 4, 1997. The post-seminar evaluation form was completed by twenty-two persons, while the remaining eight did not respond. The reason for their non-response was not solicited. However, they were not members of the new church. One noticeable recommendation for future seminars was the need to increase the length of time for the presentation of each chapter or segment.

\section{$\underline{\text { Results of Seminar }}$}

The results of the Seminar are as follows:

1. Question 1--22 members responded to the evaluation form.

2. Question 2--1 person between the ages of 12-20 years; 8 persons between the ages of 21-45 years old; 13 persons between 46 years and over. 
3. Question 3--8 persons said yes; 12 persons said no. (Most people have questions about church construction before the seminar)

4. Question 4--11 persons said yes; 5 persons said partially; 6 persons had no. (Most people had their questions answered in the seminar)

\section{$\underline{\text { Response }}$}

5. Question 5--twenty-two persons responded to the survey questions out of thirty people who attended.

a. $\quad 8$ persons strongly agreed; 12 persons agreed; 1 person disagreed (most agree that the seminar was Biblically based.

b. $\quad 9$ persons strongly agreed; 13 persons agreed (21 felt that the subject was clearly presented)

c. $\quad 9$ persons strongly agreed; 9 persons agreed; 4 persons had no opinion (18 were satisfied that information was practical)

d. 11 persons strongly agreed; 11 persons agreed (all responding, 22 satisfied that the presenter presented new materials)

e. $\quad 12$ persons strongly agreed; 9 persons agreed; 1 person had no opinion (21 felt more informed after seminar)

f. $\quad 11$ persons strongly agreed; 10 persons agreed; 1 person had no opinion (21 found the seminar inspirational)

6. Question 6 - Segment ' $e$ ' was the most popular segment.

a. 2 persons found ' $a$ ' most useful (Biblical rationale for church-building projects). 
b. 6 persons found ' $b$ ' most useful (Church Architecture and Design/Communication).

c. 6 persons found ' $c$ ' most useful (Short history of the development of church-buildings).

d. 4 persons found ' $d$ ' most useful (Origin and development of some dominant church architectural features and design).

e. 9 persons found ' $e$ ' most useful (Influences of church architectural design on liturgy).

f. 1 persons found ' $f$ ' most useful (Bermudian churches architecture and design).

g. 3 persons found ' $\mathrm{g}$ ' most useful (Seventh-day Adventist Church Theology, Liturgy, and Architecture).

7. Question 7 - There were no written responses to Question 7

8. Question 8 - 4 persons requested that more time be allotted in future presentations for each chapter or segment.

\section{Seminar Conclusion}

1. Most people attending the seminar felt the material was informative and inspirational as to why Adventist church buildings have fundmental differences from other Christian buildings.

2. Most people seem satisfied that the material had Biblical authority.

3. Most people felt more informed about church building after the seminar. 
4. Most people felt that influences on church architectural design and liturgy was the most popular segment.

\section{Seminar Recommendation}

That a longer time frame be allotted for each chapter or segment in future presentations. That the overall time of the seminar should move from a two hour to a four hour presentation.

\section{Summary}

The presenter was happy with the response of those who attended the seminar and felt that the information shared would enhance the love and appreciation for Adventist theology and how is impacts church-buildings and worship. 
APPENDIX B

BUILDING A NEW CHURCH WITH A YOUNG CONGREGATION 
In July, 1974 I was appointed Pastor of the recently formed thirty-seven member congregation, located in the Somerset area of Sandy's, Bermuda. This new congregation had no church home and was renting the lower level of a Free Mason Hall. While the Free Mason Lodge tried to accommodate the church's presence in their building, there were times when the church's program had to be altered owing to the Lodge's annual programs.

In 1975 , the congregation was able to secure a piece of property in the Somerset area. In 1977 their church building project began. This building project was to be accomplished largely through volunteer labor on the part of the church's membership.

Within the congregation there were a few professional builders such as, masons, carpenters, electricians and a building foreman.

As the pastor of the congregation, I viewed myself as the spiritual leader, shepherd, and chief motivator. I also served as chairman of the building committee. I used my position to ensure that proper procedures were followed, that collective input of the members encouraged, met with the architect and the suppliers. It was convenient for me to accomplish these tasks because of my flexibility of time. I can testify however, that this program was physically demanding because I still maintained my pastoral responsibilities.

As a building committee, we met on a regular basis and sent recommendations to the church board, who in turn forwarded them to the church in business session. Before an architect was engaged, we assessed our needs and even produced some rough sketches of what we envisioned.

Once the architect was engaged and he completed the preliminary drawing and 
they received rectification from the building committee, church board and congregation in business session, he was than authorized to proceed in producing working drawings or finished drawings. By the time the finished drawings were processed and approved by the Planning Department of Bermuda, the estimated cost of the project was determined. The locally approved drawings and financial budget were than sent to the higher organizational bodies for approval, (the Mission/Conference, Union, North American Division). Upon receipt of their approval, the congregation was permitted to commence the building project.

Before the project was actually commenced, we held a ground breaking ceremony; the land and the project was dedicated to God for the purpose of a church facility.

Throughout the duration of the building project, we held services of thanksgiving and celebration whenever a significant structural development was accomplished, (i.e. completion of the underground water tank, the first floor, the second floor, the roof).

As Pastor and chairman of the building committee, I regularly promoted the building project to the membership. I frequently complimented the congregation for their support, faithfulness, voluntary labors and sacrifices. I also preached sermons of faith and encouragement, and success stories of others who had built a house for the Lord. The congregation responded by exhibiting faith, sacrifice and hard work. On Sundays and some public holidays, members came out to work. I faithfully attended work rallies and joined in the work experience. Our time together often entailed work, fellowship and socialization after the designated task for the day was completed. These periods of work and recreation provided a meaningful way of releasing energy and, at the same time it galvanized relationships between the members and the pastor and members. So as to 
include everyone in the building project, the ladies and some men of the church, regularly prepared lunch for the workers on Sundays.

After two years of construction, the entire church structure was erected and the exterior completed. The lower interior level was first completed, which included the Sabbath School classrooms, fellowship hall, kitchen, and main rest rooms. Upon receipt of a temporary approval and occupancy certificate from the Planning Department, the congregation moved in from its rented facility to its own church.

Work continued on the upper interior level, which contained the sanctuary, pastor's study, board room and small chapel.

Throughout the building project, fund-raising events were kept in harmony with the council of Ellen White and the church's policy, mostly that of sacrificial giving on the part of the membership. On special days, such as Christmas, Thanksgiving and Easter, special appeals were made in advance for the building project. The Lord blessed the members and many friends with unselfish hearts and they responded generously with financial gifts. In addition to the financial gifts by far the greatest contribution made to the building project, came from the faithful commitment of the members, who donated many hours in volunteer labor.

By 1982 the total church project was completed, and a final certificate of occupancy was issued. The cost of the project was well within the projected budget. In addition two baptisms had resulted from individuals who had worked as volunteers on the project.

The Somerset Seventh-day Adventist Church stands as a labor of sacrifice, commitment and love by its Pastor and members to God. Its presence in Bermuda firmly 
sets it as a lighthouse of God's truth. Truly God had blessed this congregation in a marvelous way. The Sabbath the church commenced worshipping in the sanctuary area, we dedicated the entire building on the same day. This dedication was made possible because all indebtedness for the project had been paid without the church having to borrow any money from the bank or lending institution. The church was valued at one million, four hundred thousand dollars.

Reflecting on the Somerset Seventh-day Adventist Church building, more space could have been allocated for an administration area. The Sabbath School classrooms could have been larger and more space provided for the departmental departments.

By and large the church is meeting the needs of its current membership, but as it continues to increase more space will be needed to fully meet all its demands. 
APPENDIX C

RAZING AN OLD CHURCH STRUCTURE TO THE GROUND AND BUILDING A NEW ONE 
In 1984, I was appointed to pastor the Hamilton Seventh-day Adventist Church, located in the city of Hamilton, Bermuda. Before my arrival as pastor, the congregation had processed plans for a major addition and renovation to their existing thirty-five year old church building. This church building had been dedicated in 1949, it was the second oldest Adventist Church building in Bermuda. It, therefore, held historic and sentimental value and sentiments to its members and the community.

Upon arriving at the Hamilton Church, it became obvious to me that many among the 450 membership felt their existing two-story rectangular shaped masonry church structure, measuring $75^{\prime}$ in length and $42^{\prime}$ wide was aging and in need of structural care. The windows were narrow, the bathroom areas were inadequate, the fixtures were old and out of date, and the roof over the sanctuary leaked and was in need of replacement. The building lacked disability features and rails. There were no administrative offices, and most Sabbath School classrooms had no direct entry into them. The baptismal pool was under the pulpit and the choir loft area. Whenever there was a baptism the pulpit, choir and chairs had to be removed.

The additions and renovations plans I inherited, called for an extension three stories high, 42 feet wide and approximately 72 feet long. This extension was proposed to be constructed on the back side or the southern elevation of the existing church building. The northern elevation of the building which had the main entrance located in it faced King Street, a major traffic artery in the City of Hamilton, Bermuda. This entrance door was being proposed to be relocated to the back of the new extended part of the church. This meant that the main entrance doors into the church was being removed from easy visibility of the public. 
In reviewing the proposed plans for the church's extension with the building committee some major concerns and observations arose such as:

1. How will the proposed new floor elevations connect to the existing old floor elevations?

2. The old structure was predominantly constructed of steel, concrete and stone with the roof slooping from north to south. The new proposed elevation of the new section would sloop even further along the same line from north to south.

3. The windows for the proposed new section were wider than the windows of the existing building.

4. The old structure was two stories high and the new section was to be three stories high.

5. The church located in the city of Hamilton, had limited property and space for further development.

In seeking advice from an architect in light of our concerns, the building committee decided to reconsider its original proposed extension and renovation plans. The idea of razing the existing church-building to the ground and rebuilding an entirely new churchbuilding, which could incorporate the space and needs of the proposed extension and provide features for ministry for its members and friends into the 21 st century seemed feasible.

As the idea gathered momentum and found support among members of the church, it also received favorable support from the architect, some of the older members, and the professional tradesmen of the church. The Building Committee, therefore formulated a recommendation to the church board, recommending that the existing church-building be 
razed to the ground and that a new church-building be built incorporating the space and facilities for ministry into the 21 st century. This recommendation was accepted by the church board and forwarded to the church body for their final determination.

To assist the church board members and the membership at large in their understanding as to what a new church-building would look like, the building committee had architectural sketches of the potential new building developed. These sketches gave the board members an idea of the potential development of the area and thereby helped to influence their decision.

Weeks before the church business meeting was conducted, notice of the agenda was given to the congregation. The proposal for the new church was published and every member was urged well in advance of the meeting to attend a duly called church business meeting to consider the recommendations of raising the existing church and building a new church-building.

On the Saturday night of the church business meeting one hundred and eighteen (118) members out of 450 members were in attendance. Before any discussion ensued, on the proposed new church, the congregation took an action stating that two thirds $(2 / 3)$ per cent of the membership present had to vote favorably for the recommendation of the board, in order for the action to be carried out.

After much discussion, questions, and prayers, the membership present at that meeting voted on the recommendation of the church to raise the existing church building and construct a new church. The vote was ninety-eight yes, three no's, and seventeen abstentions. Although the church had voted yes, to razing the old church-building in light of the historic value of the church-building, to the members and their emotional ties to the 
building; for many of the members, had memories of baptism, marriage, dedication, funeralization of loved ones and personal worship experiences, I suggested that the action taken be reconsidered in a month's time.

At the end of the month, the congregation was once again called together to reconsider their previous action to raze the old church-building and construct a new one. At that time there was no attempt to change the former action.

With the support of the church body, we engaged an architect and directed him to produce working architectural plans for the new project.

When the plans for the new church were completed, with financial projections, they were sent to the following entities: From the church, to conference executive committee, following the Conference committee to the Atlantic Union Executive Committee and finally to the North American Division Building Committee. The estimated cost of the completed new church was 2.5 million dollars.

As the time drew near to raze the existing church building, I encouraged the congregation, to take pictures of the building. We made special mention about celebrating the last communion, the last baptism, the last prayer meeting and preaching the last sermon in the old church-building. These events provided the congregation an opportunity to gracefully part with their church-building that had been so meaningful to them in their Christian journey and spiritual experience.

On the Sunday morning designated for razing the church, as the heavy equipment and construction machines moved in at sunrise to commence the task, a large number of members, came out to witness and photograph the event.

By September 1996, a new church-building stood completed and the members 
were able to worship in their new church home. During the project many members worked hard, sacrificed much and demonstrated deep commitment to the project. This building process brought together professional tradesmen and unskilled members who volunteered their time and labor. Their fundraising methods were consistent with the guidelines of church's policy for church-building. Money for the project came from gifts of friends, but largely through the systematic financial support of the members. Both higher administrations of the Bermuda Conference and the Atlantic Union also contributed.

During my pastorate at the Hamilton Seventh-day Adventist Church from 1984 1990, and having begun the new church project, I can say that it was our love to God and the saving of souls that motivated our actions to build a new church to meet the changing needs of the membership and the community. Following my departure from the Hamilton church pastorate, the new pastor carried the project to its completion.

At the writing of this thesis, the church had received a final occupancy certificate from the Planning Department. The structure is designed to accommodate seniors and disabled persons by its gentle sloping ramps, hand rails, restroom facilities equipped for wheelchairs. In addition there is provision for the administrative office space, children's classrooms for all the lower divisions, passageways leading to rooms, an adequate fellowship room, a sizeable foyer, a visible baptism pool, centrally located communion table and pulpit, electronic provisions, sound system, adequate lighting, and so on. The cost of the project was within its budgetary projection.

This project has been a source of witness to the power of Christian unity, for the church-building is located in the city of Hamilton, Bermuda. It captured the attention of 
the local press and as such many news articles have been written about its architectural elegance and the way the members constructed it. I honestly believe that the new Hamilton Seventh-day Adventist church is a witness to the Bermudian public of its members faith and love for Jesus and His second return and their willingness to share their resources for the cause of God.

Reflecting on the Hamilton church building project, the limitation of land space made it impossible to develop a larger administrative area. However, a youth center owned by the church provides additional space for administration offices and youth social activities. 
APPENDIX D

CHURCH FACILITY SURVEY OF NEEDS SHEETS 
SECTION II

CHURCH FACILITY SURVEY OF NEEDS

I. REQUIREMENTS FOR WORSHIP

A. SANCTUARY:

1. Attendance Data:

Avg 10 yrs ago Avg this year Avg for Design

2. How many should the sanctuary seat?

3. Do you want seating in a balcony?

4. Rostrum arrangement

a. Do we need two levels?

b. Will 13th Sabbath programs be presented?

c. Are one or two pulpits desired?

d. Number of seats required?

e. Open or closed front?

f. Is space for greenery to be provided?

8. Are the piano and organ to be located here?

h. Are there special requirements for door or passages to the rostrum?

5. Seating Arrangements, etc.

A. Is a center aisle required?

b. Are movable or fixed seats desired?

c. Any special arrangement preferred?

6. Should some walls be movable for varied seating?

B. WORSHIP TRAINING ROOM

1. Is this space required?

2. Where should it be located?

3. Is it to have a toilet?

General Conference of Seventh-day Adventist, Suggestions to Building Planners. (Silver Spring, MD: Building Plans Committee, 1991). 
4. What type of furniture desired?

5. How many people will use this rosm?

C. MUSIC PROGRAM

1. How many people should be seated in the choir?

2. Where should the choir be located?

3. How will the choir function?

4. Is a robing room needed?

5. Will the choir practice in the robing room?

6 . What are the music storage requirements?

7. Do you expect to have a pipe organ?

8. Will an electronic organ be used?

Self-contained speakers

Remote speakers

9. Any special location for the organ?

10. What size of plano will be used?

11. Any special location for the piano?

D. BAPTISMAL SERVICE

1. Where should the tank be located?

2. May the tank be entered from one side or both sides?

3. Are changing rooms for men and women to be provided?

4. How many people would be in the room at one time?

5. Are these rooms to have toilets?

6. Is robe storage space desired in the changing roous?

7. Can other roons be used for changing rooms?

E. COMMUNION SERVICE

1. Ordinance of Humility

a. Where will the ladies serve each other? 
b. Where will the men serve each other?

c. Is storage for towels and pans to be provided in each area?

d. Is hot and cold water to be provided in each area?

2. Lord's Supper

a. Is a special room needed for preparations?

b. Is special storage needed?

c. Will this service be conducted in the traditional Adventist way?

F. PRAYER CHAPEL

1. Will a special room for prayer and meditation be provided?

2. If yes, how many people are to be accommodated?

G. AUDIO-VISUAL

1. Is a built-in projection screen to be used?

2. Is built-in projection equipment required?

3. Any special equipment to be used?

H. ELECTRONIC COMMUNICATION SYSTEM

1. Is voice amplification desired at the rostrum?

2. Are hearing aids to be provided at the seats?

3. Where are speakers to be located outside of the sanctuary?

4. Is voice communication between rooms required?

5. Is a signal system to be used? Describe.

II. SABBATH SCHOOL REQUIREMENTS

A. ADIRT DIVISION

1. Attendance Data:

Avg 10 years ago Avg this year Avg for design 
2. Will opening exercises be conducted in the sanctuary?

3. How many classes w111 there be?

4. WiIl all classes meet in the sanctuary?

5. If not, how many classrooms are needed?

6. Is a pastor's classroom desired?

7. What type of furniture will be used in these classrooms?

8. Is built-in storage needed? Describe.

\section{B. YOUTH DIVISION}

1. Attendance Data: Avg 10 years ago Avg this year Avg for design

2. Will this division meet with the adult division for opening exercises?

3. How many classes will there be?

4. Will all classes meet in this room?

5. If not, how many classrooms are needed?

6. What type of furniture will be used in these classrooms?

7. Is built-in storage needed? Describe.

\section{EARLITEEN DIVISION}

1. Attendance Data:

Avg 10 years ago Avg this year Avg for design

2. Will this division meet with the adult division for opening exercises?

3. How many classes will there be?

4. Will all classes meet in this room?

5. If not, how many classrooms are needed?

6. What type of furniture will be used in these classrooms? 
7. Is built-in storage needed? Describe.

8. Will the Earliteen and Junior Division be combined into one division?

D. JUNIOR DIVISION

1. Attendance Data:

Avg 10 years ago Avg this year Avg for design

2. Will this division meet with the adult division for opening exercises?

3. How many classes will there be?

4. Will all classes meet in this room?

5. If not, how many classrouns are needed?

6. What type of furniture will be used in these classrooms?

7. Is built-in storage needed: Describe.

E. PRIMARY DIVISION

1. Attendance Data:

Avg 10 years ago Avg this year Avg for design

2. Will opening exercises and class activities be conducted in this room?

3. If not, what activities will be conducted elsewhere?

4. Is it to have a toilet?

5. What type of furniture will be used in conducting individual class activity?

6. Is built-in storage casework required? If so, describe articles to be stored.

F. RINDERGARTEN DIVISION

1. Attendance Data:

Avg 10 years ago Avg this year Avg for design 
2. Will opening exercises and class activities be conducted in this room?

3. If not, what activities will be conducted elsewhere?

4. Is it to have a toilet?

5. What type of furniture will be used in conducting individual class activity?

6. Is built-in storage casework required? If so, describe articles to be stored.

7. Is a sink required in this room?

G. CRADLE ROLL DIVISION

1. Attendance Data:

Avg 10 years ago Avg this year Avg for design

2. Will opening exercises and class activities be conducted in this room?

3. If not, what activities will be conducted elsewhere?

4. Is it to have a toilet?

5. What type of furniture will be used in conducting individual class activity?

6. Is built-in storage casework required? If so, describe articles to be stored.

7. Is a sink required in this room?

8. Is this space to be shared with the Worship Training Room?

H. VACATION BIBLE SCHOOL

Are there any special space requirements needed for this program?

I. BRANCH SABBATH SCHOOL

Are there any special space requirements needed for this program?

III. ADMINISTRA'TION

A. PASTOR'S STUDY 
1. Any special location degired?

2. How many people will use this room at one time?

3. Is a telephone to be installed?

B. CHURCH OFFICES

1. Will there be a secretary employed?

2. Will there be a work room provided for duplicating?

3. Is there to be separate or combined spaces for clerk, treasurer, Sabbath school secretary?

4. Is Lay Activities to have a separate room?

IV. COMMUNTTY SERVICES CENTER

1. Is this to be included in the project?

2. If yes, refer to the Community Service Center program outline?

v. SOCIAL ACTIVITIES

A. LOUNGE AND LIBRARY

1. If this is in the program, how many people will use this room at one time?

2. Should it include a fireplace or kitchenette?

B. FELLUWSHIP DINNERS

1. Number of people to be accomodated?

2. Kitchen facilities required?

C. WEDDINGS AND FUNERALS

Are there special requirements to be considered?

D. PATHFINDER CLUUB

Should this be considered?

VI. CIRCULATION

A. LOBBY OR (NARTHEX)

1. How many people should be acconmodated at one time? 
2. Are there special requirements here such as guest book, tract rack, bulletin board, etc.?

\section{B. AUTOMOTIVE}

1. Is a drive-up porch area for passenger accommodation desired?

2. Is a material loading or unloading space to be considered?

3. How many parking spaces are needed? Check code requirements.

VII. SANITARY FACILITIES

\section{A. TOILETS}

List the areas where these are to be located.

B. JANTTORS' CLOSETS

Note any special need.

C. SEWAGE DISPOSAL

1. Is a public sewer available?

2. Will a septic tank system be needed?

\section{STORAGE}

A. Will each department have space for its own materials?

B. Is an outside maintenance storage room desired?

C. Are there any special storage requirements?

IX. UTILITIES

A. What type of heating system is preferred?

B. Will cooling be included?

C. Are there any special lighting requirements?

D. Is there city water available or is a well required?

X. GENERAL APPEARANCE

A. INTERIOR

Is there some special material desired for the following? 
1. Sanctuary: Ceiling

Walls

Floor

2. Other Rooms: Ceiling

Walls

Floor

B. EXTERIOR

1. Is there a special requirement for roof style or shape?

2. Are there any special requirements for wall surface materials?

3. Is a particular type of window desired?

4. Security lighting and facility protection (door locks, fencing, etc.)

C. MISCELLLANEOUS

1. Should the overall design follow a contemporary or pertod architecture?

2. May this building be a copy or similar to another church?

3. Is it necessary to include the following items in the design?
(a) Stained glass
(b) Cross
(c) Steeple

4. Should a sign or building identification be incorporated into the design? 
APPENDIX E

PLANNING FOR CHURCH BUILDINGS 
SECTION I

PLANNING FOR CHURCH BUIIDINGS

\section{Finances}

A. What is the estimated cost of the building?

If the architect cannot provide a detailed construction cost estimate, consider having this done by someone professionally trained in cost estimating. During the planning processes, it is very important that the congregation and the building comnittee have accurate estimates of building costs, to facilitate realistic financial negotiations.

\section{B. Is this cost figure realistic?}

Divide the estimated cost of the project by the number of square feet in the building to determine the cost per square foot. (Example: A 5000 square foot building with an estimated cost of $\$ 100,000$ would cost $\$ 20$ per square foot.)

Find out the average cost of buildings in your area that have used similar materials and methods of construction. This cost/sq. ft. should be revised periodically to keep pace with changing prices. Compare this figure with the estimated cost per square foot for the project. If this figure is lower than the going rate, the estimated construction cost may be unrealistically low. This can be especially critical to a church working under a tight budget. When the bids come in on the project, the building may cost more than the church can afford. Then the church has to go through the cost and delay of preparing a revised set of plans.

\section{Site}

A. Is the site conveniently located to serve both present and future church nembership?

\section{B. How large is the site?}

The size of the site depends on a realistic projection of how large the church will become. An average site should contain between two and five acres to provide enough space for the building, sufficient on-site parking, and room for future expansion. For larger churches, five acres would be a minimum. As a general rule of thumb, one acre can accommodate 160 cars.

C. How much on-site parking is provided?

In rural and some suburban areas where automobile transportation becomes a necessity, the parking area should provide approximately one space for every three persons seated in the

General Conference of Seventh-day Adventist, Suggestions to Building Planners. 
sanctuary. In urban and metropolitan areas, this ratio should be adjusted according to the availability of land and of public transportation. Be sure to consult local parking space requirement codes.

D. What is the auto traffic pattern on the site?

A person should be able to drive up and drop passengers at a major point of entry, under a canopy, and proceed directly from there to the parking area. After the worship service or church program, this traffic flow should be able to work in reverse.

E. Does the site provide grade level auto access to each level of the building?

Stairs present a problem to many elderly people and the handicapped. Exterior stairs can be a safety hazard in the winter when ice and snow make them slippery. For these reasons, there should be grade level access to all floor levels of the proposed facilities. A flat site with the building at grade most easily overcomes these obstacles. In cases where the topography dictates a multi-level building, however, provision should be made to facilitate grade level access and a pair of rest rooms with handicapped toilet compartments on each floor.

When an existing building that lacks grade level access is being renovated, ramps should be installed at a major entrance to the building with a slope no greater than $1: 12$. This allows a person in a wheelchair to move up and down the ramp unassisted. Consideration should also be given to ice and snow problems in the winter. Make sure that handrails are included when planning ramps and/or steps.

F. Can the site accommodate future expansion of the building and parking?

This is a particular problem with remodeling schemes. In many cases there is insufficient space on the site for an addition as well as necessary parking space. This problem should be given much consideration since it could become a factor for relocation.

G. Consideration should also be given to the following architectural and planning criteria:

Consider southern exposure an asset in cooler climate areas (northern states), and northern exposure an asset in warmer climate areas (southern states).

Relate the proposed facility to the existing on-site and adjacent buildings, both physically and architecturally.

Provide sidewalks from the parking areas to the major entrances. 
Consider how future land acquisitions or sales on adjacent sites relate to the needs and specifications of the building program.

Work with the types of foundation and supporting structure that best meet the existing soil conditions.

Maintain as many existing natural elements as possible. This includes trees. shrubs, interesting rock formations, etc.

Consider landscaping as an important architectural element, rather than a "superfluous" cost item.

Include outdoor lighting for the building and parking areas to provide security and permit night use of the building. Design lighting so as to be vandal-resistant.

\section{Organization}

A. What is the general layout of the building?

The main entrance to the building should be easily accessible from the parking area, and should be designed with a drive up canopy entrance. This permits covered access to the building during inclement weather. The building should be organized so that people can easily orient themselves once inside the front doors. A key feature in this kind of arrangement is a large, centrally located narthex that serves as the circulation hub of the building. A person should be able to proceed directly from the narthex to the sanctuary, fellowship hall, or classrooms. For convenience, the church offices and rest rooms could also be located off this area. Not only does this make them more accessible but it also enables the secretary to monitor the main entrance from the church office.

\section{B. Is the narthex large enough?}

The narthex should not only serve as the building's circulation hub, but also as a place where people can hang their coats and talk informally before and after a worship service, assembly, or fellowship dinner. To encourage this kind of activity, the narthex should provide at least $2 \mathrm{sq}$. ft. of unobstructed space for every person seated in the sanctuary or fellowship hall, whichever is larger. (Example: If the sanctuary seats 300 people, the narthex should provide at least $600 \mathrm{sq}$. ft. of space, plus additional coat room and storage areas where needed.) The coat storage should line the walls of either the narthex or classroom corridor rather than in a separate coat room. This allows people to get their coats easily, unlike a coat room, where there is usually a crowd of people trying to get coats at the same time.

C. Are there situations where people have to pass through one activity area to get to another? 
The building should be organized so that people can get from one part of the building to another without having to pass through any of the activity areas and disturb the people who are using them. (Example: In a classroom it would be difficult to maintain the attention of the class with people walking in and out of the room.) Avoiding this interruption of one area to reach another, however, does not necessitate or imply an overabundance of corridor space. To the contrary, an efficient church plan limits the amount of corridor to a minimum, yet avoids having to cross a classroom to reach another area.

In larger churches the floor plans seem to work most efficientIy when divided into separate zones for education, worship and fellowship. Besides simplifying the church plan, this allows use of each zone without disturbing or even opening other areas. $i . e .$, the fellowship hall might be in use for a community function, while other church areas are closed and locked.

\section{Worship Room}

The worship room is to be designed to enhance the church service. The service consists basically of provisions for the preaching of the word and the ordinances of baptism and holy communion. Since the ministry of the word and the ordinances are important, the architectural plan should give emphasis and stress to the pulpit, table and baptistery.

The worship room may also be used for other functions such as receiving new members, weddings, funerals, and choir programs. Because of this, the pulpit and table should be portable.

The design and arrangement of the worship room should reflect the fact that the minister and congregation come together in a corporate act of worship. The platform on which the pulpit and table are located is a distinct area because of the functions involved, but it should not be separated from the congregational seating space.

Since the major emphasis is upon preaching, baptism and communion, architectural features such as windows should not distract from the service. The seats for the minsters should also be properly located.

\section{Sermon}

The pulpit is a place designed specifically for the preaching and reading of the word of God. This does not exclude the possibility that in some instances this function may take place elsewhere in the room.

The location of the pulpit affects the relationship between the sermon and the congregation. The minister must be able to see the congregation and the congregation must be able to hear and see the minister. 
Listening to a sermon is a corporate activity. The minister must be aware of the response of the congregation to the sermon even though the response is unspoken. Conversely, the congregation needs to see the minister. They need to see his facial expressions and his gestures. This can be achieved by elevating the pulpit, so that even those seated in back of the room can see the minister.

The rapport between the minister and congregation can be destroyed, however, if the pulpit is raised too high or if it is located at too great a distance from the congregation. If raised too high, the viewing angle becomes oppressive.

6. Choir

The function of the choir is to lead congregational singing (hymns), to sing to the congregation (anthems), and to sing on behalf of the congregation (choral responses). In addition, many choirs offer sacred concerts on special occasions. The choir should be located so as to best fulfill these functions.

The organ console should be located so that the organist could direct the choir. The organ chambers should be located so that the organist might balance the music of the organ and choir. The director should be easily seen by the choir without being conspicous to the congregation.

Space should be allowed in the design of the worship room for the use of instruments or unusually large choir groups on special occasions. If chairs instead of pews are used in the choir loft, this space may then be used for the placement of musical instruments.

\section{Congregational Space}

The worshipping assembly should be situated so as to suggest their active role as participants in worship. Worship is a corporate activity. It involves the minister, the choir and the congregation. It does not represent a performer-spectator relationship. The size, shape and arrangement of the room should emphasize the understanding that worship involves the entire congregation in the service. This can be achieved by bringing the congregation closer to the worship centers and by planning for a level floor. Conversely, long narrow rooms which place a large number of the congregation at a great distance from the minister and rooms which have sloping floors and balconies which emphasize the spectator-performer relationship should be avoided.

\section{Order of Worship}

The normal service for most churches places emphasis on the spoken word-invocation, prayers, reading of the scriptures, responsive reading, sermon and benediction. The worship room should be designed to provide the best possible acoustical environment for these functions. It is imperative that the 
minister be able to communicate directly with the congregation without having to resort to artificial aids such as a public address system. The size and shape of the room and the materials employed should contribute to the effectiveness of the spoken words.

9. The Order for the Administration of the Lord's Supper

Adequate space should be provided for the table to store the communion materials. Additional space will be needed for the pastor and his assistants to work behind the table as they prepare the emblems for serving.

10. The order for the Service of Marriage

The aisle leading to the chancel should be of ample width (5' to $7^{\prime}$ ) for the procession of the wedding party. There should be a way to signal the organist when the bride is ready to make her entrance.

There should be sufficient space at the front cross aisle for the wedding party. If the ceremony takes place on the raised chancel area, the wedding party will not block the congregation's view of the couple.

11. The Order for the Burial of the Dead

There should be sufficient space for carrying the casket from the front door of the church with a minimum number of steps and shapes. The doors should be sufficiently wide. The aisle leading to the chancel should be at least $5^{\prime}$ to $7^{\prime}$ wide if pallbearers are to walk alongside of the casket.
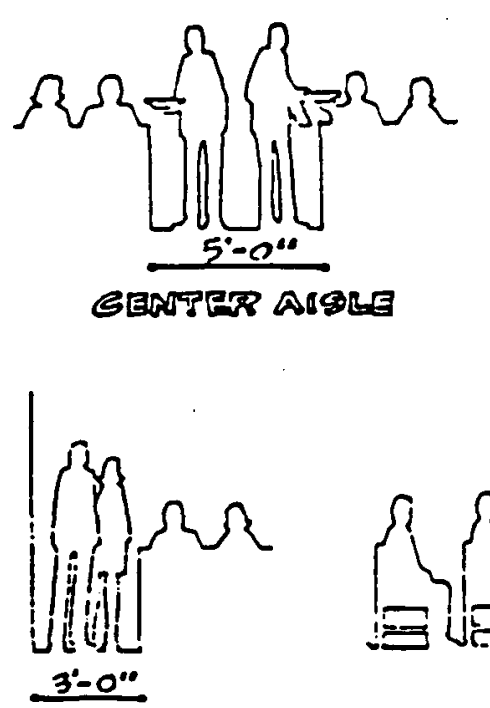

SIDB AIBRE
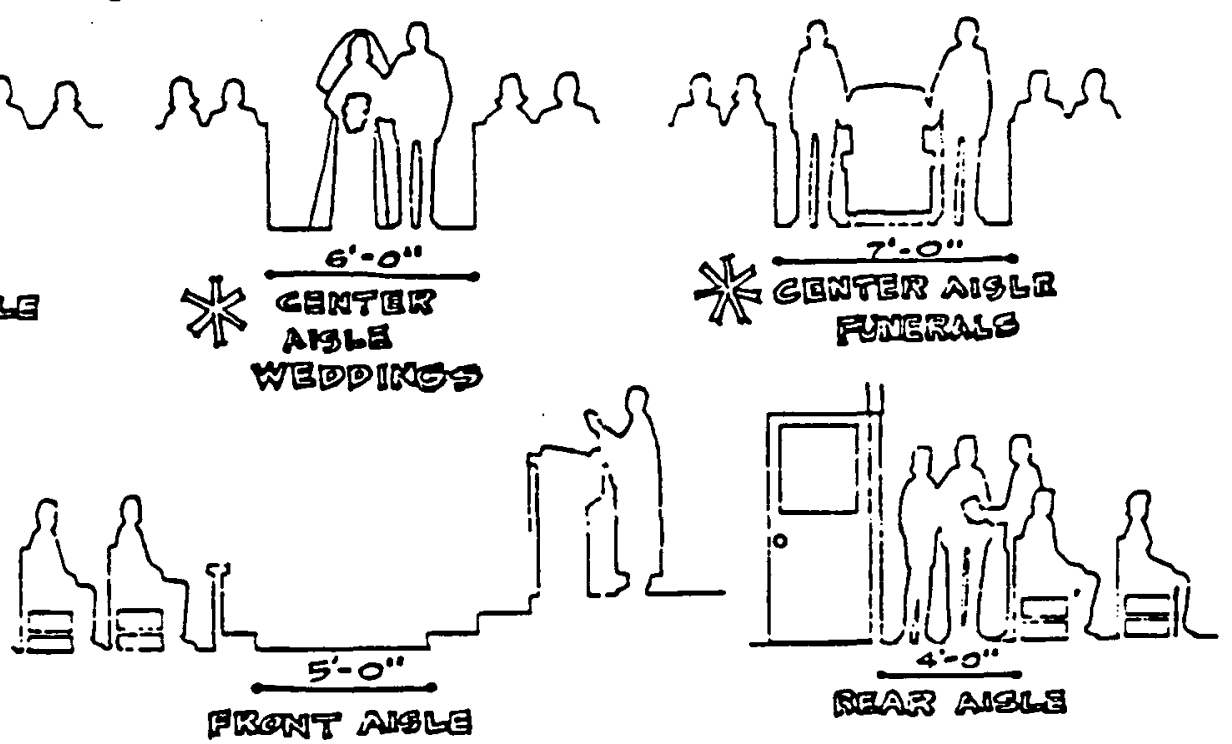

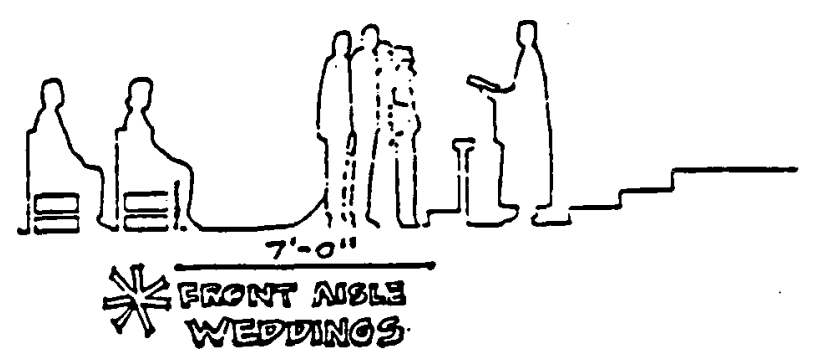




\section{Acoustics}

"So faith comes from what is heard, and what is heard comes by the preaching of Christ." -Romans 10:17.

Basic to the design of the worship room is its acoustical environment. Provisions must be made for the spoken word, responses, choral prayer and praise, congregational singing, and the organ. No other single factor is of greater importance than the acoustics of the room. If a choice must be made in the design and arrangement of the church, let acoustics take precedent over aesthetics. We do not fulfill the task before us when we build for appearance with the vague hope that the room will prove to be satisfactory when it is in use. It would be to the advantage of the church if an acoustical consultant were employed to advise the architect.

A worship service depends primarily upon the ability of the congregation to hear and understand the spoken word and choral music. The size, the shape, and the architectural treatment of the worship room should reflect this basic theme. Worshippers should be able to recognize and understand speech from the pulpit. If congregational singing is to be encouraged, the nave should be designed to enhance the sound of the singing. The choir should be arranged so that choir members hear each other adequately.

The requirements for good hearing conditions can be simply stated, and in principle are the same in a church or auditortum. The church is perhaps the most complicated kind of auditorium, because of the variety of sound sources-both speech and musicand the conflicting visual requirements. The realization of the basic requirements for good hearing conditions in any space, and a common-sense knowledge of how sound behaves in an enclosed volume, are really all that are needed to achieve success. The somewhat interrelated requirements for good hearing conditions in any space, then, are as follows:

A. Background noise must be low enough so as not to interfere with the desired sounds of speech and music.

B. Speech and music sounds within the church must be sufficientiy loud, both at their source and to the listeners, to permit

"easy" listening.

C. Sounds must be distributed properly throughout the room to give uniform intensity of sound for the greatest number of listeners. Good sight lines usually mean good hearing lines. This means that it is highly desirable to elevate sound sources. Since worshippers seated in the nave make a highly absorptive surface, it is desirable to elevate the sources of sound for both good hearing and seeing. 
The use of the ceiling as a reflective surface is basic in the design of a room for good hearing conditions. It can be shaped and refined in many ways, but basically it should be hard and sound reflective. It must never be sound absorptive (acoustical tile or acoustical plaster) without explicit reasons. The celling is the most important surface in the room for assuring adequate loudness and good distribution. Concave shapes, even if their surfaces are broken up, should be avoided. Close-in, sound reflective surfaces or canopies suspended directly over the speaking positions can be extremely effective in reinforcing a speaker's voice.

D. Undesirable reflections (echoes, points of sound focus, etc.) must be eliminated by care in the design of surfaces that create these problems. Generally, it is better to substitute surface shapes that break up rather than absorb sound. Severely symmetrical forms, including cubical and spherical shapes, should be avoided. Canted ceilings, splayed or irregular, serpentine walls and random shapes, and spacings can be helpful in achieving a good pattern of sound distribution.

Very wide roons should be avoided. Because of the directional effect of the human voice, it is difficult to achieve uniform distribution. For best effect, the congregation should be arranged inside a cone of 90 degrees with its apex at the pulpit.

E. The reverberation time in a room is arbitrarily defined as the time required for the sound to decrease to one-millionth of its original intensity after the source has stopped. The reverberation time must be short enough to avoid excess overlapping of successive sounds and yet long enough to provide the essential blending for music and support for the spoken word. In general, we need a relatively long reverberation time for sufficient blending of musical sounds, but a shorter one for the proper understanding of speech. Although the ideal acoustical conditions for music are not exactly the same as those for speech, for rooms up to 100,000 cubic feet in volume there is very little practical difference.

Fortunately, there is a range of reverberation time which will allow satisfactory conditions for both, and the designer must concentrate on achieving an appropriate compromise in his design. In the final analysis, the reverberation time desired will be a judicious compromise involving speech definition, congregational singing, choral music, varying types of organ compositions, room volume, the amount of sound absorptive material in the room, and the emphasis which the congregation desires to place on these various factors.

The most important sound absorbing material in a large listening space is the audience itself. The number of people present in the space and the volume of the space automatically fix the upper limit of the reverberation time. The absence of people will change drastically the reverberation characteristic. The 
only satisfactory solution to this problem is the use of some form of sound absorption which will be exposed during services with small occupancy and covered up with full congregations. Upholstered pew cushions are a practical way to accomplish his result.

\section{Lighting}

Light gives form to the interior and Iife to the Order of Worship. Wighting and architecture go hand in hand. Without lighting, architecture would have little meaning. Lighting in the place of worship should be comfortable, functional, coordinated with the service, and suited to the architectural design. There is a particular task and function in each area of the church and for this reason the lighting of the nave, chancel and choir areas should have individual attention. The demands that the Order of Worship make upon each area should be discussed in detail with your architect and engineer so that they can intelligently plan the lighting. There is no standard or absolute way of lighting a church.

\section{A. The Nave}

The nave vertical fixtures should complement the architectural design. In an interior of perpendicular proportions (that is, with height greater than width) fixtures of similar proportions are more compatible. In interiors of horizontal proportions (width greater than height, or in areas where height and width are about equal) fixtures of similar proportions are appropriate. Down lighting is most important and if the fixture has luminous side panels, care must be taken in selecting lamp wattages to avoid unfavorable brightness. An upward component of light from a pendant mounted unit gives an indirect lighting effect which helps to overcome undesirable shadows.

\section{B. Congregational Seating}

The area should have an equal distribution of light and a minimum of 10 foot candles has been found to be satisfactory in interiors of dark finishes. In lighter finished areas (white plaster walls, white woodwork) a 15 to 20 foot candle level is more comfortable. This difference is due to contrast of articles such as printed inatter, clothing, furniture and wall finishes.

Cove lighting can be interesting in many nave areas. This is usually fone with fluorescent equipment. Special consideration should be given to the overlapping of fixtures so that unattractive shadows from ends of lamps are not noticeable. Fluorescent ballasts should be located elsewhere to avoid the usual humming noise. Cove lighting should be used on side and rear walls only. Dimming control is available for adjusting the light level. 


\section{Pulpit Area}

The level of illumination in the chancel should be twice as much as in the pew area. This helps to command the attention of the congregation. The pulpit lighting is best done by concealed floodlights. The pulpit must have supplementary lighting and this is best done from two sources, -45 degrees in horizontal plan and 45 to 55 degrees in the vertical plan. An interesting effect is obtained by having unequal intensities of light coming from each source. This can be achieved by placing one light source further away or by varying the wattage. A pulpit lectern light is acceptable when used in conjunction with other directional lighting.

\section{Choir}

The light on the music should be sufficient for the easy reading of notes and instructions even when the sheets are held nearly vertical. Light, therefore, should come from behind the singers. If the singers face the congregation, the light sources must be shielded to prevent glare in the eyes of the congregation.

Light on the faces of choir nembers should arrive at proper angles to avoid shadows under eyebrows and nose. The general illumination in the chancel will usually be ample light for this purpose. In general, choir areas should have more light than is provided for pews, less than pulpit or lectern. A level of 30 foot candles is recommended (two-thirds of this value for dark interior finishes). This level should be reduced or dimmed during sermon, prelude, or meditation.

\section{E. Control}

Manual control for dimining should be located in the narthex and at the pulpit. The nave lights could be dimned one-half during the sermon. The dimaing device should be protected against tampering by an unauthorized person. Separate controls should be provided for nave lighting, pulpit and lectern, floodlights, choir and for other chancel lights. Simple switching arrangements are better than complicated selector switches because the sanctuary lighting may be operated by inexperienced and changing personnel.

\section{F. Exterior Lighting}

Floodlighting of the exterior should be of the type and intensity that will accentuate the particular attractive architectural features of the structure. The color and texture of the wall surface determines the type of floodlighting fixture and lighting source selected. Light from too great a distance loses the effect of wall texture and joints. A better effect can usually be achieved by floodlighting the building from two sources at a corner rather than lighting one surface only. 
Floodlights that illuminate the interior of an important stained glass window should be located so that they are not apparent when the interior is in use. Windows of the sanctuary can be lighted best from floodlights on the inside. No outside lighting should be played on the wall adjacent to the windows. Dark areas of the structure should "frame" the illuminated window.

Locate outdoor floodlighting fixtures so that they are not annoying or distracting when entering or leaving the building at night. Floodlighting fixtures should be located so they are not conspicuous in the daylight. Shrubbery, if the fixtures are located on the ground, provides an adequate hiding place. Remember, fixtures located on the ground are more subject to vandalism.

All floodlights should be controlled by autonatic time switches or light cells so that the hours of illumination will not require the services of church personnel. High quality sealed units are better than open fixtures. Wire guards and protective devices may be necessary as a precaution against vandalism. In some areas, consideration may be given to lighting which is controlled by heat and motion sensors.

\section{G. Church Lighting}

For a more detailed study of this subject a booklet Church Lighting is available from the Illuminating Engineering Society, 345 East 47th Street, New York, NY 10017. Phone 1-212-705-7926. This booklet is well illustrated and covers the field of interior and exterior lighting.

14. Sabbath School Rooms

In an average congregation, large or small, with the usual distribution of age zroups, it is impossible to provide adequate classroom space for children and youth in a basement or semi-basement located under the main sanctuary and lobby. This is particularly true if rest rooms, mechanical rooms and general storage rooms are also on the lower level. Surveys show that more than $50 \%$ of the total Sabbath School membership is for children and youth.

No fewer than five division rooms are required in churches built to seat up to 150 persons. No fewer than six classrooms should be provided in larger church buildings.

For ideal classroom activities the Cradle Roll requires from 25 to $35 \mathrm{sq}$. feet per child. Other children and youth divisions require about $20 \mathrm{sq}$. feet per child, and adults 12 to $15 \mathrm{sq}$. feet per person.

Building committees should plan for at least some small rooms or partitioned areas for adult classes. If the Sabbath School is to reach the potential in evangelism and in fostering spiritual maturity among its members, it must maintain its small 
class structure without being crowded so close together that noise and confusion result.

In preliminary plans submitted to the General Conference Building Plans Comittee, Sabbath School classrooms should be clearly marked as to intended use as: Cradle Roll, Rindergarten, Primary, Junior, Earliteen, Youth, Adult, etc.

A rest room should be attached to or immediately adjacent to Cradle Roll and Rindergarten rooms.

Carpeting or other soft-textured floor covering should be provided in Cradle Roll and Rindergarten rooms. The electrical outlets should be above the reach of small children or should be plugged.

Storage facilities for visual alds, books, helps, and room decorations should be provided in each division room or in a central supply area.

Controlled heating, lighting, and ventilation should at least meet minimum code requirements for public school classrooms of comparable size.

The pastor's study should be made large enough to accommodate the pastor's Bible class which, according to surveys, will attain a membership of from $5 \%$ to $10 \%$ of the total Sabbath School membership.

If possible the practice of having one or more divisions share the use of a room with other activities, such as welfare or a fellowship hall should be avoided. It should be recognized that a large room partitioned by folding doors or movable partitions to make two or more Sabbath School classrooms, is much less than ideal.

Very long and narrow rooms are practically a waste of space, since usable arrangement for general classroord activities is impossible.

\section{Welfare Service and Centers}

Provisions should be made for welfare societies to meet in the church building. The room should be for then alone. For better relations with and convenience to the community and city, the Community Services Center should be where it can best serve the people. This is usually away from the church. If it is necessary for the center to be in the church, a separate entrance should be provided.

Health and Welfare Services Center or the Community Services Center is established only under the direction of the local conference, and the whole church should vote for it and give its support. Thought and study should be given to provide all the 
necessary equipment and space necessary to carry on an effective program. A Health and Welfare Services Center provides the following advantages:

Increases soul-winning opportunities

Makes possible giving aid to more persons

Provides office space for the organization

Provides work rooms

Provides space for instruction in classes needed by the clients such as home nursing, first aid, cooking, sewing, etc.

Provides storage space for stockpiling materials needed in disaster and emergency

Improves public relations of the whole church

A Community Services Center should be the responsibility of the entire church or churches which support the center. There should be a close relationship and cooperation between the center and other local welfare agencies. In planning for the center an adequate financial budget should be worked out in order to have the finances necessary to care for the emergencies which will arise, as well as a competent staff to man the center.

Architecturally, whether the center is in the church or in a separate building, it should have the following physical characteristics:

A building or quarters suitable and adequate to fill the needs.

An attractive sign in an appropriate place giving the hours open and the purpose of the office.

An entrance opening directly from the street and clearly identified.

Space for private interviews.

Adequate storage for supplies, work space, etc.

Electrical connections for kitchen facilities, sink, refrigerator, stove, appliances, washing, ironing and sewing facilities. (These, especially for the cooking area, should be so placed that it can be used in teaching cooking and nutrition.)

Windows which will allow plenty of light. 
Adequate cupboard space built in or allowed for movable cabinets.

Adequate electrical outlets conveniently located.

Note: See Health and Welfare Manual for detailed instructions for both Welfare and Community Services Centers. 


\section{PROPERTY COMMITTEE MANUAL}

by Norman N. Lueck

Frank W. Klos, Editor

Parish Llfe Press

Phlladelphia
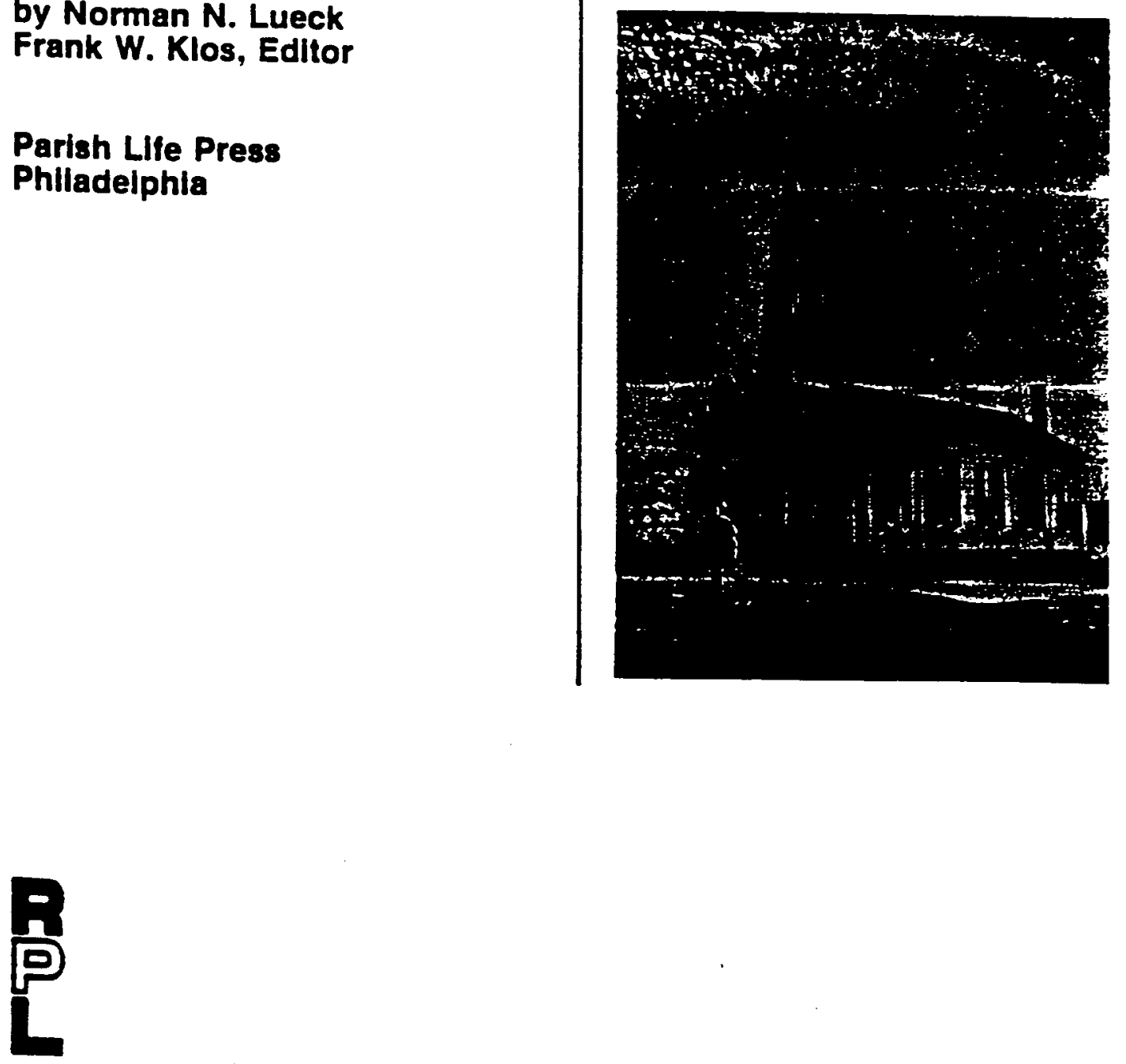

RESOURCES FOR PARISH LEADERS 
- Note any hardware missing from doors and windows.

- Are doors provided with panic hardware in compliance with local building codes?

- Condition of floors, floor covering, or carpeting in all areas.

- Check for wear, damage, and cleanliness.

- Check walls and ceilings for cleanliness.

- Check all electrical outlets, lights, and switches. Check the condition of air conditioning units.

- Check all exit signs for illumination, visibility, and good order. Are they in compliance with local code and sufficient in number?

- Check condition of all chalkboards, bulletin boards, etc.. for proper attachment to walls.

- Are instructions clearly posted about what to do in case of fire at various places and locations in the building?

- Check the proper placement and condition of fire extinguishers.

- Check on first-aid kit and its availability with necessary contents and emergency numbers posted.

- Check all storage areas and rooms for cleanliness and neatness and freedom from combustible materiais.

- Check out heating plant and furnace room for cleanliness, neatness, and compliance with local codes and requirements.

- Are oil mops and rags stored properly to prevent spontaneous combustion?

- Are remote storage areas such as under staircases and staircases clear of combustible materials?

- If smoking is permitted, are ash trays available in meeting rooms and lounge areas? Are they used instead of wastebaskets?

- Check for water damage and leaks.

- Check for dry rot and termites and rodents.

- Check the condition of pews, tract racks, storage cabinets, appliances, and other fixtures in need of repair and care.

- Check all interior woodwork and trim for conditioning and protection needed.

- Check all cabinets, files, etc., for content, neatness, and orderliness.
- Check all inside plumbing for leaks and proper operation.

The development and planning of new buildings or structures is Deyond the scope of this handbook. However, the property committee should be alert to congregational needs so that suggestions for new buildings or renovations can be included in long-range plans.

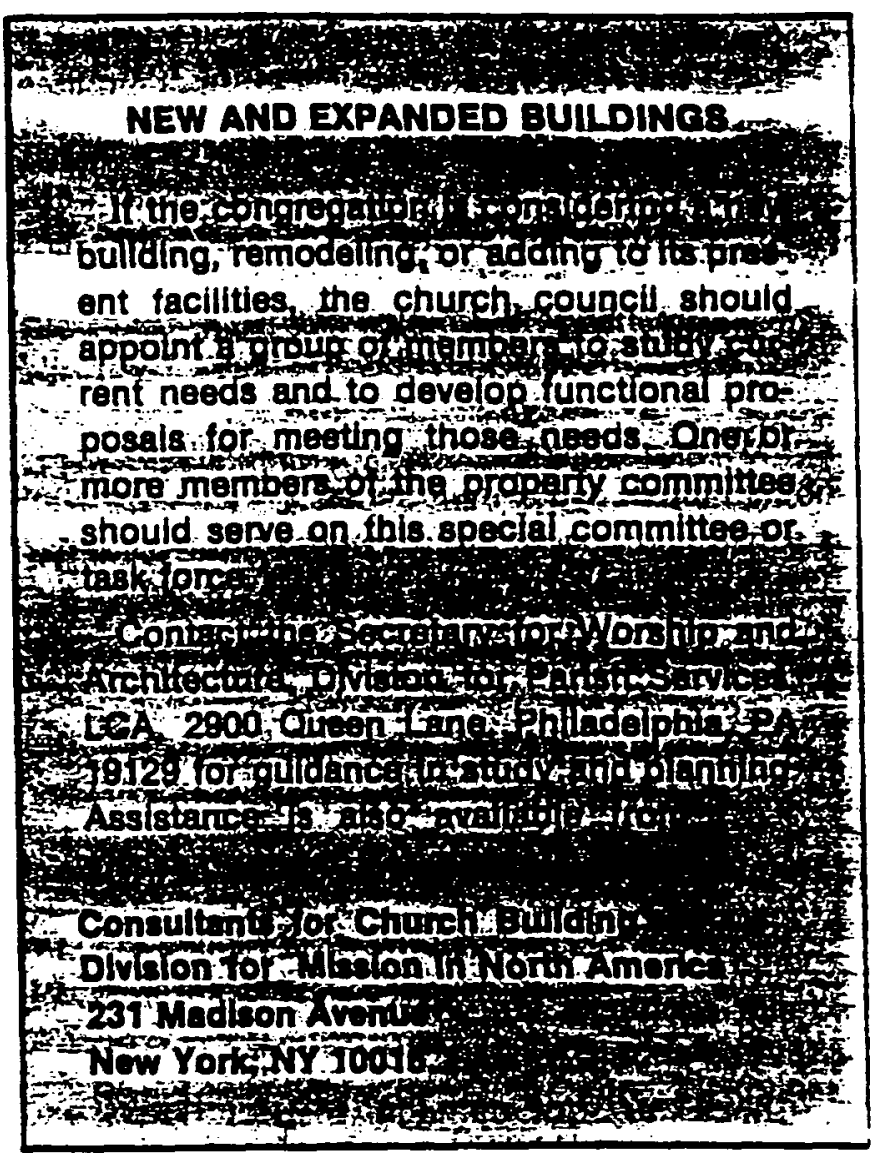

\section{SPECIFIC AREA AND ROOM CONCERNS}

Each congregation has a physical climate in its facilities that says a great deal about the quality of ministry it supports. Certain areas of the church, therefore, should be under continuous scrutiny by the buildings and structures subcommittee to make sure that the climate is warm, friendly, and inspiring.

\section{Entrance and Narthex}

It is here that the worshipers enter the church; it is here that the visitors receive their first impressions of the congregation as a community of 
disciples of Jesus Christ. Some typical questions to ask regularly include:

- Are the walks, steps, and thresholds in good repair and clean?

- Is there an easy access to the building for the elderly? The handicapped? Are there adequate ramps or railings? Is there another entrance that is or can be equipped with special ramps or lifts, well marked and identifiable?

- Are adequate and orderly facilities available for hats, coats, umbrellas, rubbers, overshoes? Are these areas adjacent to, but not causing congestion in normal traffic patterns?

- Do the doors open out and easily? Are they locked securely? is there adequate weather stripping to keep out drafts?

- Is the narthex well lighted, clean, neat, and orderly?

- Are the literature racks, display tables, bulletin boards, and member boxes neat, orderly, clean, kept updated with new and current materials?

- Is the guest book prominently located and easily accessible?

- Are book storage areas, cabinets, and display tables kept clear of unused articles and outdated materials?

- Are these areas being used wisely for the purposes intended?

\section{Sanctuary}

The sanctuary is the area of worship where the gathered community of believers interact with God and his holy Word. The following questions are of coricern to the buildings and structures subcommittee as well as to the worship committee.

- Are the heating, cooling, and ventilation equipments noisy?

- Is there good air flow distribution and circulation?

- Does the system adequately provide the necessary cooling, heating, and ventilation?

- Do the lighting fixtures enhance or detract from the service of worship?
- Do the organist and choir have good lighting?

- Is there enough light, is it well distributed without glare?

- Are the puipit and lectern lights adequate for the pastor? Do these lights bother worshipers?

- If there is a rheostat on the lights in the chancel and nave, does it function properly?

- Do the chancel lights enhance or detract from the chancel?

- Who is responsible during worship for the operation of the system?

- Are microphones free from feedback?

- Are speakers properly placed for total distribution of sound throughout the nave?

- Are there hearing aids for those who are partially deaf? Are these aids and their location properly marked?

- Are banners artistically attractive and displayed in good taste?

- Are the banners changed so that the ones displayed are always appropriate for the occasion or church year season?

- Are pews free from sticky varnish or paint?

- Are they securely fastened to the floor?

- Are they in good repair and clean? Slivers and cracks can result in damage to the clothes of the worshipers. The undersides should be free from chewing gum.

- If there are pew kneelers, do these operate quietly? Are the pew racks attached firmly and tree from squeaks?

- Is the aisle and floor covering soundproot? is it in good repair?

- Are windows clean and in good repair? Can extreme glare or sunlight be controlled?

- If the windows are vented, do the vents operate easily?

- Do classrooms and meeting areas give a good indication of their function?

- Are the floors clean and in good repair? Are ample wastebaskets available?

- Are storage cabinets, shelves, chalkboards, tack boards, and other equipment being utilized well, in good repair, and kept orderly?

- Is the lighting adequate? Are there sufficient electrical outlets for audio-visual equipment? 
- Is the classroom space being used wisely?

- Do classrooms provide adequate space and such environment as to foster learning in accordance with the latest educational standards?

\section{Llbrary or Media Center}

Many congregations are including a librarylounge area in new plans and/or renovating older facilities to create space for use as a library or media center. The buildings and structures subcommittee should cooperate with the Christian education committee in developing proposals for these projects. Where libraries or media centers now exist, some questions to be answered are:

- Is the library conveniently located?

- Is there a good floor covering to create a relaxed atmosphere and to control noise?

- Are there sufficient sheives in good repair and order?

- Are books, magazines, and other media materiais stored neatly and orderly with ready accessibility for users?

- Is there adequate seating as well as table top work area?

- Is there adequate protected storage for audiovisual equipment?

- Are other than library or media center materials unnecessarily stored in this area?

\section{Fellowship Hall}

Most congregations have a fellowship hall or some large area where a number of varied activities and events can take place such as congregational dinners, large meetings, community services, drama, wedding receptions, youth groups, scouts. In the light of specific activities and events held in this area, these questions are important:

- Is the area clean, orderly, and inviting? is it serviceable and adaptable?

- Is it properly equipped for various needs?

- Is there adequate storage for various equipment needed in its utitization?

- Are the floors and walls in good repair?

- Is the area adequately heated, cooled, and ventilated?
- Does the area comply with local codes regarding sanitation and safety?

- Is there one or more well-marked and functioning emergency exits?

- Is the area easily accessible to the kitchen and a good pattern of flow for food service established?

- Are fire extinguishers and first-aid kits readily available?

\section{Kitchen}

Kitchens should be properly equipped, well ventilated, easy to clean, efficient and have ample storage space. These questions need to be answered:

- Are instructions on use, care, cleaning, storage, and local fire regulations prominently posted?

- Is there scrupulous compliance with fire and building codes and regulations?

- Is the kitchen area kept clean, neat. and orderly?

- Is proper ventilation provided?

- Are the heating, plumbing, and electrical supplies adequate and in good order?

- Are all kitchen items, including appliances, properly cleaned and stored?

- Are there provisions for adequate waste and trash disposal?

- Is the kitchen used as a storage space for other items than those related to kitchen use?

\section{Pariors and Lounges}

These areas of the building are usually set aside for special events and occasions including small receptions. They are often used, as well, for committee meetings and study-discussion groups. Cleanliness, neatness, and order are a must. Comfortable furnishings in good taste help create an informal, relaxing atmosphere. Some questions to pursue are:

- Do the lounge facilities meet the needs of the congregation?

- is there suitable lighting for the various purposes for which these areas are used?

- Are the areas properly heated, cooled, and ventilated? 
- Are the areas on special thermostat control so they can be used independently, apart from the rest of the building?

- Are the areas free from clutter and inviting?

\section{Administrative and Secretarial Offices}

Parish offices should be clearly marked, near a main entrance and have easy access for deliveries and visitors. These rooms should be functional, provided with good lighting as well as adequate ventilation, heating, and cooling. Floors and walls should be clean and in good repair. Space should be adequate for work required. These are also areas that the visitor is exposed to which communicate a lot about the congregation's life-style and form of ministries. Some points to be aware of in relation to the office areas are:

- Is there sufficient and orderly storage for supplies and parish records?

- Are the furnishings adequate to perform various administrative tasks? Arranged for most effective usage?

- Is the office equipment on a regular maintenance and replacement schedule?

- Is the office equipment properly stored?

- Are the offices clean, neat, and attractive?

- Are emergency instructions posted prominently?

- No unnecessary storage of articles or materials not related to administration.

\section{Pastor's Sludy}

The pastor's study is a personal room. Pastors, therefore, should have complete freedom to determine the kind of furnishings and equipment they need as well as the use of this room. No one should use the pastor's study without permission or consultation. Pastors should feel that personal effects and private records are safely protected in their studies. Since pastors often use these facilities for counseling and small group meetings, they should be aware that the atmosphere of the room contributes a great deal to the effectiveness of these activities.

\section{Storage Areas}

Storage areas are essential. However, these areas frequently become disordered catchalis, causing difficulties in retrieving items as needed. The subcommittee should make certain that this does not happen. Storage areas should be inspected at least once a month for cleanliness, orderliness, and fire or safety hazards. Unnecessary a.ticles and items should be ruthlessly discarded.

\section{Youth Rooms}

Some congregations set aside a special room for youth gatherings and meetings. This is an excellent idea but this area can become a shambles unless there is proper supervision of the area and communication of expected care, cleanliness, and order by those using it.

Youth should not exclusively be expected to maintain good care of the facilities they use. A monthly inspection tour by the subcommittee is in order. Follow the same checklists as for the other fellowship and lounge areas of the church.

\section{THE PARSONAGE}

The parsonage is the responsibility of the buildings and structures subcommittee unless there is another subcommittee charged with overseeing the care and condition of the pastor's home. It is suggested that whichever option you follow in your parish, there should be persons serving on the subcommittee who are sensitive to the needs around a home.

Specific subcommittee tasks concerning the parsonage should include:

- Semiannual inspection of the exterior and interior of parsonage and garage. (Adapt the general checklists provided for all church buildings. Refer to pages 13-14.)

- An annual visit should be made on the pastor and his family by several subcommittee members to discuss ways that the parsonage can be made more nearly like the home the pastor's family desires. Those who live in the parsonage are also more aware of the needs for improvements, repairs, and maintenance than the subcommittee could possibly be. Besides, this visit demonstrates the loving concern of the congregation for the comfort of the parsonage family.

- Attractiveness of the parsonage and grounds. The parsonage should be one of the best cared for and attractive houses in the community, but not necessarily the most expensive. The parsonage is a representation of the church to the community. 
APPENDIX F

SELECTION OF A CHURCH SITE 


\section{Selection of a

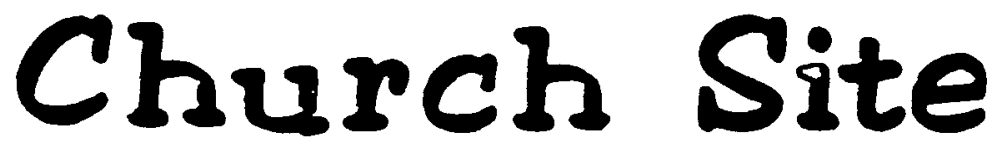

CHURCHES ARE BUILT TO STAY:

GOOD LOCATION IS IMPORTANT

- by Everett L. Perry

Where should our church be located? This question arises immediately after a decision has been made to start a new church, or when an older church intends to build a new edifice. Granted that the general area for work w1ll be carefully chosen with due regard for comity procedures, we are concerned here with the selection of a speciflc site.

Consideration of four general criteria and the use of comon sense and good judgment in the balance secured among these four will go far toward securing an adequate church site, which will provide a physical basis for institutional growth and for effective churching of a local community. With an adequate site, a building program may be projected over a period of years or decades. If the site is inadequate, it is extremely difficult, and in some instances impossible, to compensate for this weakness by the building, staff or program.

\section{FOUR GENERAL CRITERIA}

Accessibility. Churches are designed to serve people. An obvious but often neglected principle is that the church should be located as closely as possible to the people it is going to serve. Ideally, the site should be such that a maximum number of people are within walking distance of 1t. Accesstbillty may be increased by the presence of public transportation, ease of access to and from a main thoroughfare, and adequare provision for off-street parking.

Visibility. The church building by its very location can give the impression of being an important aspect of community life. The church on the public square, near the Capitol, on a site dominating the countryside or at an important intersection, exemplifies what we mean. It is in contrast to the small and unimpressive frame building on a narrow lot in the middle of a block and on a narrow side street, in a small and isolated residential neighborhood. A church tucked away on such a site will have grave difficulty in extending its ministry beyond the immediate environs.

Topography is an important factor in achieving visibility. Other things being equal, a site which is at a somewhat higher elevation than its surroundings is preferable to one which is lower. However, the site should not be so high that it is difficult to reach during any season either by automobile or on foot.

The location of a church within sight of a main thoroughfare may provide thousands of dollars worth of advertising value over the years. Our usual suggestion is that the church locate near a main thoroughfare, but not on it. The site should be protected so that it will not eventually be hidden from the highway by high buildings. Preferably, there should be a buffer in landscaping, an access drive, or desirable adjoining properties, so that the noise and confusion of a main thoroughfare will not be objectionable. 
Relationship to the Neighborhood Pattem. In the instance of the planned community involving the ezection of several hundred or several thousand units by one builder, the relationship of the site to the total neighborhood pattern should be studied. The site must of necessity be determined in consultation with the planners and builders. In this case, a close relationship between churchmen and those planning the new commity is essential. This is ordinarily best achieved through a local council of churches in which cooperative Protestantism can make one coordinated approach to the planners.

Probably the majortty of new churches over the country, however, are built in nelghborhoods which are elther totally unplanned or only partially planned. Regardless of the presence or absence of coordinated over-all planning, as cities grow some neighborhood patterns develop in relation to natural or artiflcial barriers, shopping centers, and schools. The best located church is one which has taken these neighborhood patterns into consideration.

A location near some neighborhood focus such as a public school or shopping center is usually more desirable than one in some other part of the neighborhood. In such a location the church has more visability and more relevance to the total neighborhood pattern. People will be coming to church in an accustomed direction of movement. If located near a school, convenience for released-time religious education programs is increased. In some instances the high school may represent a more natural focus for the wider community than does the elementary school. However, high school sites are frequently selected largely on the basis of avallability of sufficient acreage. The very fact that large acreages are thus put to non-residential use may make a location near a high school less desirable than one near an elementary school. The church near a shopping center can usually make use of its off-street parking space on Sunday. However, it may be at some disadvantage in regard to parking on week-days.

The relationship to the social-economic pattem of the neighborhood is also important. If there is a wide range of social straca in the neighborhood which the church seeks to serve, it would be well to secure as socially-neutral a location as possible, or one which ranks near or slightly above the average. However, if the church wishes to serve primarily one social or economic level, it preferably might be more specifically identified by its location with the group it intends to serve.

Adequacy. The specific site should in itself be suitable for the purposes to which it is to be put. In size, the site should be adequate for the plant to be erected, including possible additional units in the future, plus allowances for set-backs, landscaping, off-street parking, and outdoor recreation. Excess property can be disposed of later, but it becomes very expensive and sometimes impossible to acquire adjoining land if it be needed at some later date. The Presbyterian Board of National Missions has for several years advocated the securing of at least three acres for a new church site. It is recognized that in built-up areas the securing of this minimum may be impossible, but the suggestion highlights the need for property of adequate size.

It has been pointed out that a comer lot frequently can be utlized more effectively, architecturally, than can a site in the middle of the block. Also, if the manse is located on the same property, more flexibility for the whole building operation is secured. At the beginning, before the edifice is erected, the manse may prove useful for group meetings, and to center the interest of the congregation at the 
future site. Later, when expansion of facilities is needed, the manse may be utilized temporarily for the Christian education program, or it may be moved to a new location or razed to provide additional space for building expansion.

Problems relating to site preparation, such as fill, leveling, quicksand, drainage, etc., must be considered. In some instances it is preferable to secure architectural advice as to the adequacy of a particular site prior to final purchase of the property.

Zoning, deed, and other restrictions on use of the property should be carefully investigated before the property is purchased. If the site is in an unimproved or unsubdivided area, the costs of securing improvements such as water, sewerage, paving, curbing, sidewalks, etc., must be considered in the total cost of the property.

\section{SOME SPECIFIC CONSIDERATIONS}

Reference has been made indirectly to specific considerations during the discussion of general criteria. However, at least five are sufficiently important that they deserve special mention.

Barriers. Rallroad, industrial propertles, heavily traveled highways, gullies, and the like, usually limit the accessibility of a church to the people beyond. Such barriers usually function as neighborhood boundaries. The church ordinarily should avoid selection of a site near such barriers lest it find itself on the edge rather than at the center of its neighbrohood. If located on the edge, part of its normal local parish would be cut off.

Non-residential land use. Large Industrfal installations, parks, cemeteries, institutions, and the like, take up land which otherwise could be put to residential use. They limit the potential neighborhood constituency of a church. In addition, industrial properties frequently exert a deteriorating influence on nearby residential properties. Selection of a site near non-residential properties ordinarily should be avoided.

Zoning. Zoning and building codes which regulate the way in which the property can be used should always be investigated. Usually there are restrictions on the distance the new building must be set back from the street ine and from the property of neighbors, which make part of the site unusable for building purposes. In some instances zoning or deed restrictions make the erection of a church impossible.

Zoning also has important implications in its protective aspects. If the site is in an area zoned for industrial or commercial use, one can be fairly sure that residential desirability will decline. A site located in a residential area surrounded by land zoned for industrial or commercial use is likely to be in an isolated pocket in later years. Particularly important is zoning of the property between the church and the main thoroughfare which provides visability. Zoning which restricts the height of an adjoining building may protect the site's chief asset. Otherwise, protection of the site can be secured only by ownership of the land which adjoins the site. 
Selection of a Church Site

Off-street parking. In some citles zoning regulations require off-street parking in relation to the seating capacity of the church. This is becoming more general. Where not required by law, it is wise to provide adequate off-street parking for a new church. Though street parking may appear adequate at the moment, it may in years to come be utterly inadequate.

Projection of population trends. The erection of a church building is a major capital investment which will be utilized over a period of many years. An attempt must be made to visualize, as nearly as possible, not only the situation of the moment, but also what the situation is likely to be during the useful life of building. In some instances, a church will do well to select a site several blocks, a half mile, or even a mlle farther from the center of the city than at first thought advisable, so that it will be in proper position to serve the maximum number of people during its entire life. However, building investment should not be made solely on the basis of hope and expectation of future growth without tangible evidence of a commaity to be served. Particularly in the slow-growing citles, less risk is involved in staying near the established community than in moving far into the country-side to a spot which may not be populated unt1l the new building has reached obsolescence, if at all.

\section{THE CRITERIA IN ACTION}

In most cases the ideal site cannot be secured. Some compromises must be made among the criterta within the existent possibilities of securing land and the available financial resources. The cormittee and its consultants must usually appraise the possibilities and come to the soundest possible judgment. The final choice will depend to a considerable extent on the type of church which 1s Involved and the type of ministry that the church wishes to provide. Four general types are noted here.

The Neighborhood Church. This is probably the "ideal-type" in most new church development programs. It should be as nearly central as possible within the residential area to be served, at a distance from major barriers, and preferably near an elementary school or shopping center so that it will not be "lost" within the neighborhood. It should be located so that a maximum number of people live within walking distance.

The Regional Church. Frequently the development of residential neighborhoods, through the uncoordinated activity of various real estate operators, is so spotty and irregular that the church must plan to serve several small neighborhoods in one sector of the city if it is to survive and grow to reasonable institutional strength. In other words, it must be designed as a sectoral or regional church. In this instance, it is essential that the church be on or near a major radial highway and public transporation system.

The Downtown Church. If it is to remain city-wide in coverage, the downtown church must usually be located in the central business district, where it is at the hub of transporation and commerce. There it has maximum opportunity to develop a ministry cutting across all social classes. There also is opportunity to develop a program for the daytime residents of the downtown area. 
Selection of a Church Site

In some few of the larger c1tles it is necessary for most downtown churches to move to residential locations. However, in small cities of thirty or forty thousand population with little development of neighborhood structure, careful consideration should precede any deciston to move to the fringe. Such a move should be made only with a clear understanding that the church will probably become more closely tied to a particular part of the c1ty, or to a particular social or economic group.

Nationality or Racial Churches. These churches, which are becoming decreasingly relevant to the American scene, ordinarily are located near the major concentration of the group to be served. In cases where there is a wide scatterting of the nationality or racial group, a downtown location, or other location easily accessible to the total group, is preferable.

The Rev. Everett L. Perry is Research Assistant in the Department of City and Industrial Work, Board of National Missions of the Presbyterian Church in the U.S.A. 
APPENDIX G

NORTH AMERICAN POLICY ON CHURCH BUILDINGS 
The North American Division Building, Blueprints and Borrowing of Funds Committee has been organized to assist churches, schools and other denominational entities as they plan to build or to expand their facilities in order to carry on their work more effectively. The North American Division Working Policy P 1565 Building Projects - reads as follows:

1. Authorizations - Building and financial plans for church and institutional projects shall be submitted for approval according to the following plan (amount exclusive of land):

a. Projects exceeding $\$ 25,000$ shall be approved by the Conference Committee or Institutional Board.

b. Projects exceeding $\$ 200,000$ shall be approved by the Union Committee or the Board of the Union and General Conference Institutions.

c. Projects exceeding $\$ 500,000$ shall also have the approval of the General Conference Building Plans Committee and NADCOM. This shall be done in the early planning stage in order that the General Conference departments involved may be consulted regarding specific requirements.

2. Counsel from Higher Organizations - Churches contemplating either the purchase or erection of a church building shall be cautioned against undertaking financial obligations which would embarrass the membership. When a congregation decides to buy or build a new church home, its building should not be sold or vacated until provision is made to house the congregation. In all building projects, local and union committees shall give careful counsel, taking into consideration the size of the congregation, its financial strength, and the location of the building.

3. Cash Requirements - In the purchase or building of church properties, commitments shall not be made or building operations commenced until 50\% of the entire cost of the building including initial furnishings, is available in cash or in readily converted assets, and provisions satisfactory to the authorizing committees for securing the remaining $50 \%$ is made. In the case of construction, the work shall proceed and obligations shall be incurred only as funds are available. Land that has been paid for may be considered at cost as part of the required $50 \%$ of the total project.

4. Construction in Stages - In cases in which it is practicable to occupy church buildings before the contemplated project is entirely completed, authorization may be given for construction to be undertaken in stages, provided the project has been approved by the authorizing committees with

General Conference of S.D.A., Working Policy of the North American Division, (Silver Spring, MD: Review and Herald, 1996-1997). 
the provision that construction will not proceed except as funds are available.

5. Borrowed Funds - In cases where it is deened advisable, a church may be authorized to borrow up th $50 \%$ of the cost of completing the current stage of its building project, provided a definite program for the liquidation of the loan has been approved and underwritten by the local and union conferences concerned within the time period specified by this policy.

NAD Working Policy P 1570 Institutional Building and Improvenent Projects -

1. Definition - For institutional and conference building projects, improvements and equipment, $50 \%$ of the funds needed for the project shall be available in cash or readily converted assets and satisfactory provision made for securing the remaining $50 \%$ before authorization is granted by the responsible committee or board and the commitments are made. In the case of construction, the work shall proceed and obligations shall be incurred only as funds are available. When college dormitories and health care institutions are considered, NADCOM may make an exception to the policy requiring $50 \%$ of cost to be in hand. A higher percent of borrowing may be permitted to these types of projects where earned income will fund the repayment of loans on a self-liquidating basis. NADCOM will consider each case on its own merits. In cases of housing for employees where earned income will fund the repayment of loans, the Union may give final approval for construction and borrowing. In all cases where the full amount of the funds needed for a project is not available, the amount borrowed shall be underwritten by the local and union conferences concerned and the plan of finance approved by NADCOM, with the exception of Health-Care institutions.

2. Multiple Units - In the case of a building or expansion program involving one or nore units in one of the larger institutions, the plan for the building program for each unit with the financial plan should be submitted to the controlling committees for approval before commitments are made. A master buflding plan for the institution shall be developed and subritted for approval. Such financial plan shall provide for the full amount of funds required to complete the project by cash or by yearly budgetary appropriations underwritten by the local and union conferences concerned. Construction shall proceed and obligations shall be incurred only as funds are available.

3. NADCOM Approval - Any project involving the expenditure of $\$ 500,000$ or wore shall be regarded as an undertaking requiring counsel with local and union conference committees, and NADCOM as to the viability of the building and financial plans.

4. Cost Estimates - Cost estimates from the project's architect concerning contemplated building and improvement projects shall be submitted by organizations for approval by the appropriate comittees. The estimated operating expenses of the new facility shall also be submitted. 
APPENDIX H

SELECTING A BUILDING PROCESS 


\section{SELECTING A BuIloing PRDCESS}

There exists today a varfety of methods for planning and constructing church facilitics.

The Building Comittee should assemble, review this pamphlet, and select the building process best suited to the needs of the congregation. No single method for building will answer every church objective nor eliminate the need to carefully prepare a program proposal or monitor construction.

To discuss alternative building processes, study the advantages and disadvantages presented for each method. Before comparing these building processes, however, review these brief descriptions of the participants and some of the architectural terminology.

\section{participants:}

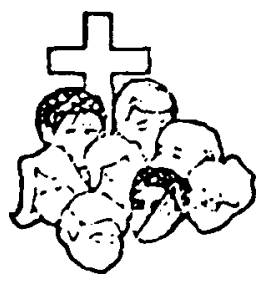

\section{church}

The new building will be only as much as you the CHURCH - make it. The quality and successs of the architect's design depends upon the quantity, clarity and scope of your descriptive instructions.

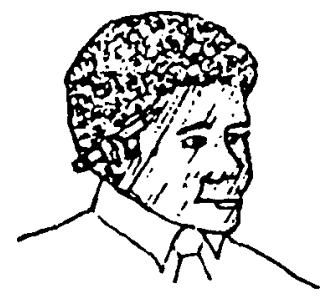

\section{architect}

The architect plans, designs and coordinates the construction of the new facilities. The architect's primary responsibility is translating the church's written description of needs into a three-dinensional reality that will best house the programs to be offered.

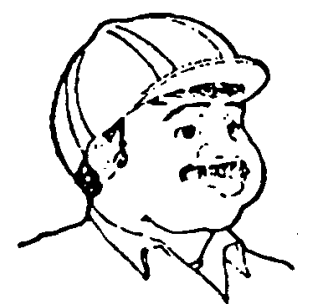

\section{contractor}

The contractor has the responsibjility of providing the equipment, labor and tiatcerials necesisary to construct the new farcilitics, in accordance with the architect's drawings and specifications. 

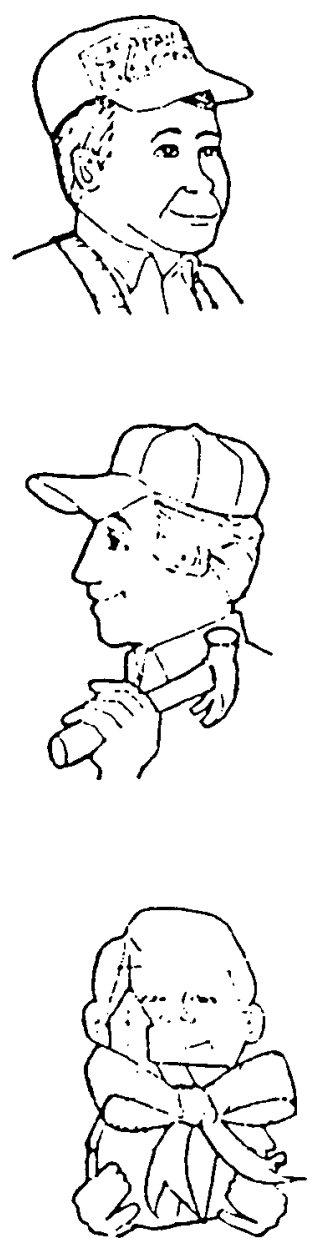

\section{terminology:}

architectural program proposal

schematic. plans

design proposals

\section{sub-contractor}

The sub-contractor has specialized tools and equipment together with an expertise in a limited area of construction to perform a specific rask in the construction process.

\section{volunteer labor}

Volunteer labor can cut construction costs by reducing or eliminating labor costs. However, it does require thorough supervision and can often extend the anticipated length of construction. Contractors asked to work with volunteer labor may increase their prices to compensate for the uncertain output and quality of volunteer work.

\section{package dealer}

The packige dealer puts desingn, construction, and even finance together in a single agreement to produce a building for a fixed price.

The package dealer often employs the services of architects, contractors and sub-contractors to complete a total building scrvice package.

The Building Committee prepares an Architectural Program Proposal that describes in detail the church programs and activities to be offered and the space needed in the new facilities. This program proposal becomes the primary written communication with the architect.

The schematic plans are the architect's first, very general plans for the new facilities. Usually they are no more than rough sketches illustrating the relationships between the interior spaces, the building to its site, and the approximate three-dimensional shape of the building ("massing").

After schematic plans are developed and reviewed, the architect revises the design, develops clevations, and prepares a preliminary design proposal. If accepted, the architect will proceed with construction documents. 
construction documents

standard plans

pre-fabrication

performance bond

completion bond
To accurately construct a building, the contractor needs detailed, dimensioned drawings, a specification booklet, and contractual and bidding information. The drawings should include a site plan (with master plan), floor plan(s), elevations, building sections, details, window, door and room finish schedules, and all necessary information for electrical, mechanical and plumbing installation. The specification booklet describes the quality, type and method of installation for materials to be used in construction. The contractual and bid information describes the conditions of the contract and procedures for hidding.

Standard plans are prepared for general use and are available from a varicty of sources. Because they are "typical" in the sense that the plan is used repeatedly, they arc based on general conditions for site, topography, climate, program needs, aesthetics, etc.

Pre-fabrication refers to a methnd of constructing buildings in pieces inside a plant and then transporting the finished pieces for on-site assembly. Since the building sections are "manuractured" in a controlled environment, and then assembled very quickly at the project site, the timeloss factor of bad weather is virtually eliminated.

bid bond This bond guarantees that a bidder will enter into contract if his proposal is accepted. If required, the amount of the bond is usually a percentage of the proposal and carries a time limit.

A performance bond guarantees that the contractor will fulfill his contract in accordance with its terms. It may include payment bond or lien bond provisions. It is usually for the same amount as the contract. We strongly recommend a perfurmance bond for every building project.

A completion bond is given by the owner to the lender or mortgager. It guarantees to the lender that the owner will finance the construction to completion, free of liens. 


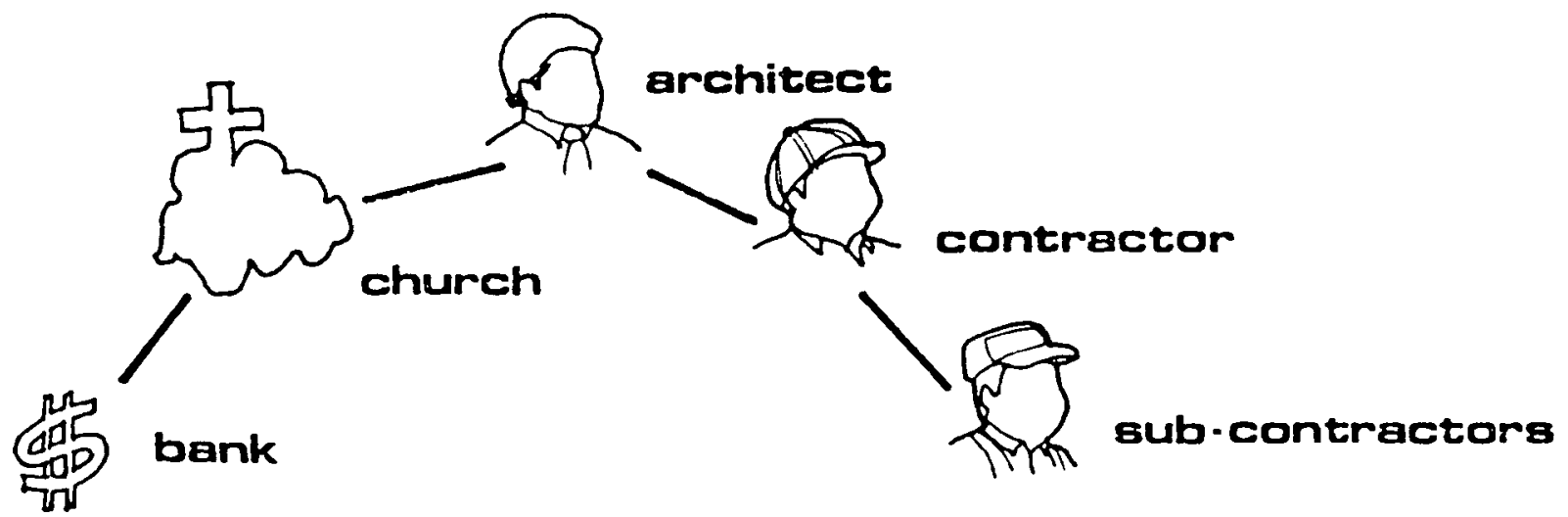

- The church hires an architect to prepare plans and supervise construction.

- Through competitive bidding a general contractor is secured.

- Sub-contractors are chosen either by open bidding or hired directly through the general contractor.

- Funding is received through contributions and/or lending agencies and coordinated by the Church Treasurer.

- This is by far the most commonly used building process. The architect acts as the agent of the owner during the planning and construction phases.

- Advantages

1. The church has complete architectural and planning services at their disposal. The building design should reflect their specific program needs and requirements.

2. The church can determine the quality of building by advising the architect to specify types of materials and equipment.

3. The church receives the most competitive prices from contractors.

4. Once a contractor's bid is accepted, the work will be completed for that fixed price.

5. The contractor is obligated to construct the buildings according to the architect's specifications. A performance bond insures the facilities will be built to completion.

- Disadvantages

1. The architect cannot guarantee a fixed maximum price until construction documents are complete and a contract bid received and accepted.

2. During the time-consuming process of preparing construction documents, costs of materials and labor are escalating. 


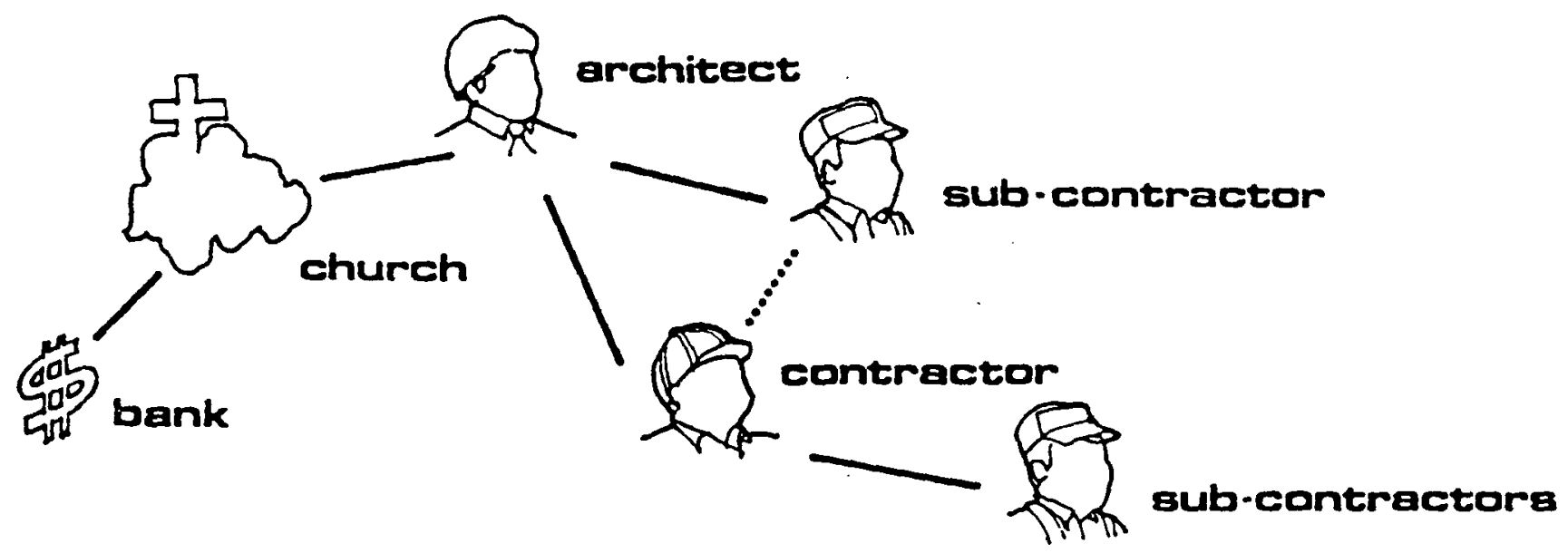

- The church hires an architect to prepare plans and supervise construction.

- When the design proposals are accepted, construction drawings for excavating, grading, foundation work and steel are prepared.

- The architect lets this work out for bid while construction documents are being finished.

- General contractors bid for the construction work, incorporating the cost of the early sub-contract.

- Funding is received through contributions and/or lending agencies and coordinated by the Church Treasurer.

- As a variation of Process $\# 1$, this second process gains validity with the escalating costs of materials and the advantage of an earlier starting date.

- Advantages

1. All those listed in Process \#1

2. Construction can begin shortly after design proposals are approved. Cost savings are realized by ordering steel and other materials promptly.

- Disadvantages

1. The architect cannot guarantee a fixed maximum price until a general contract bid is accepted.

2. Beginning to build before the completion of construction documents represents a financial commitment in a project not yet finished. If the general contract bids are greater than anticipated, funds might not be available to continue construction. Attempting to make changes in the plans when foundations have been poured and some materials ordered could be costly. 


\section{BUILDING PROCESS 3}

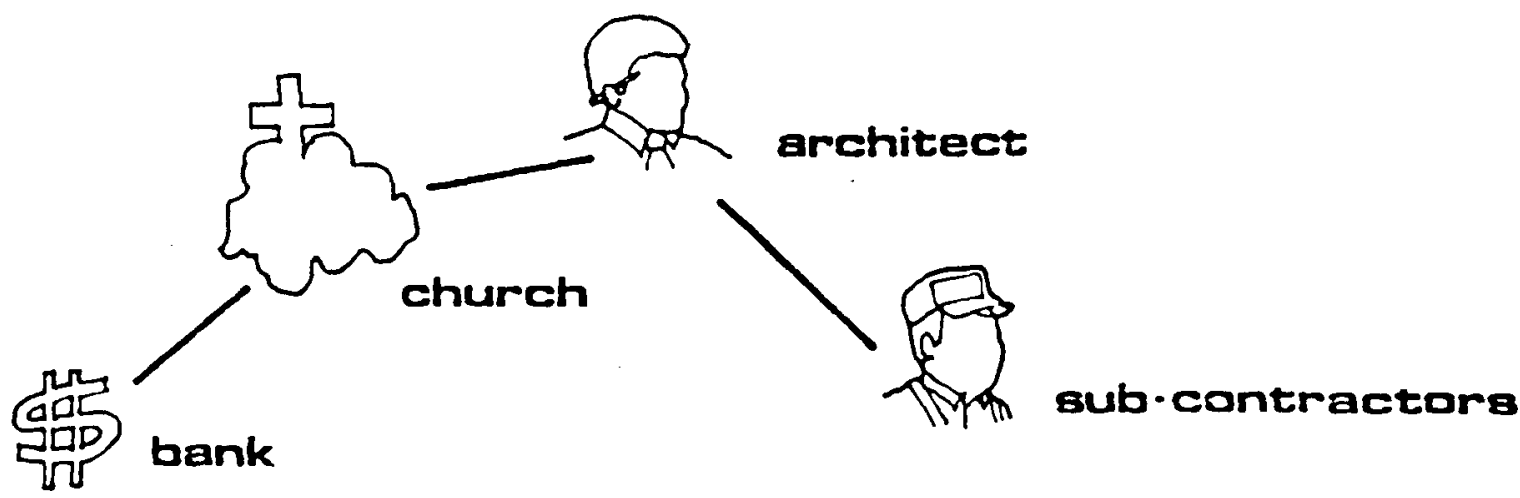

- The church hires an architect to prepare plans and manage construction.

- After plan preparation and approval, the architect coordinates purchasing materials, hiring labor and securing the necessary subcontracts.

- Funding is received through contributions and/or lending agencies and coordinated by the Church Treasurer.

- This method of operation is becoming more commonplace as architects are broadening the scope of their work.

- Advantages

1. Both planning and construction are unified in one combined professional service.

2. When compromise is necessary the architect is best qualified to make decisions of cost versus quality.

3. The architect, as planner and builder, is often able to guarantee a quality building within a defined price range.

- Disadvantages

1. An architect may not be able to realize some of the savings in material costs that a general contractor does by purchasing in larger quantities.

2. Construction management requires full-time participation, a task which the architect would most probably be unable to perform personally. 


\section{BUILDING PRDCESS 4}

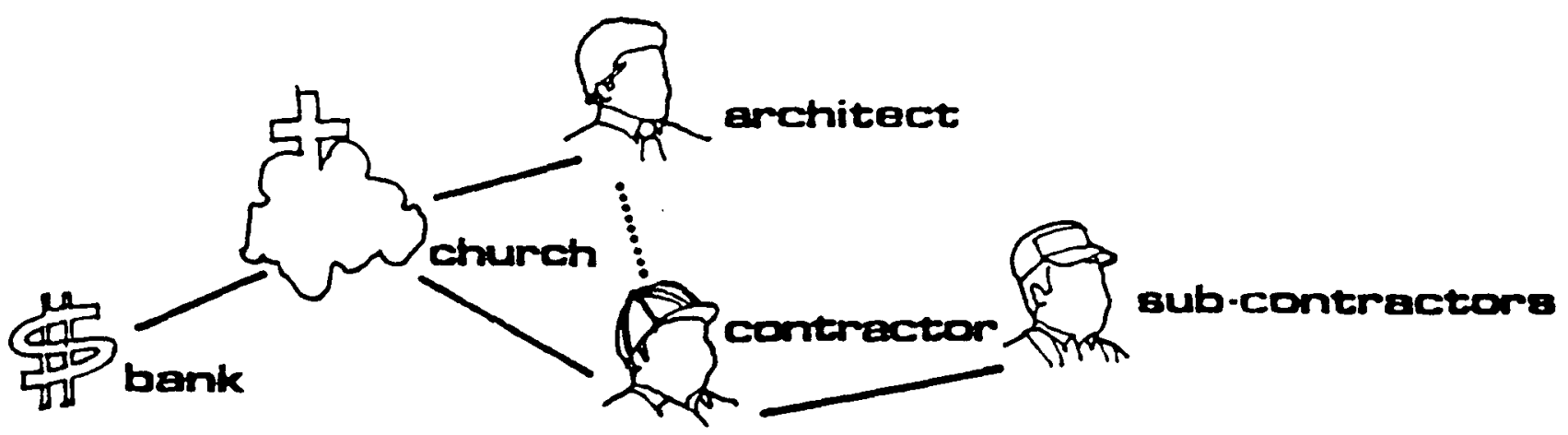

- The church hires an architect to prepare plans and supervise construction.

- Before construction documents are prepared, the church selects a contractor and negotiates a fixed fee for construction.

- All materials and labor are purchased at cost to contractor.

- The contractor takes the detailed information as it becomes available from the architect and begins ordering materials, preparing the site, and securing sub-contracts.

- When construction documents are complete, all the preliminary work should be finished and full-scale building operations begin.

- Funding is received through contributions and/or lending agencies and is handled by the Church Treasurer.

- Advantages

1. The church has complete architectural and planning services at their disposal.

2. The church can determine the quality of building by advising the architect to specify types of materials and equipment.

3. The contractor is obligated to construct the buildings according to the architect's specifications.

4. The contractor's profit is a fixed fee, with materials and labor purchased at cost.

5. Savings are realized by starting construction as soon as design proposals are approved.

6. The contractor as a paid agent of the church can work with the architect to realize further savings in construction.

- Disadvantages

1. Again, beginning to build before the completion of construction documencs represents a financial commitnent in a project not yet finished. If custs begin to exceed what was anticipated, funds might not be available to complete construction.

2. There is no guaranteed fixed price for construction. 
BUILDING PROCESS 5

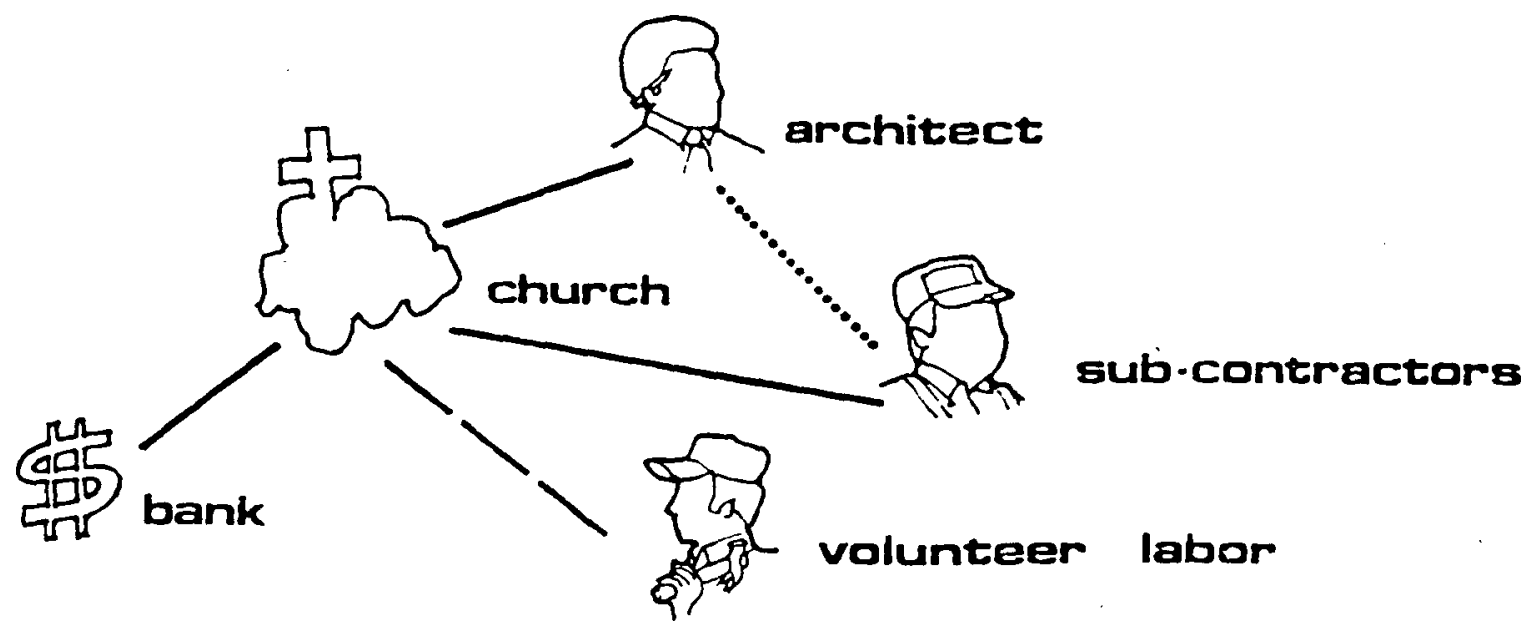

- The church hires an architect to prepare plans and supervise construction.

- When construction documents have been prepared, the church acts as its own general contractor, coordinating sub-contracts, purchasing materials, and securing labor.

- funding is received by contributions and/or lending agencies and is handled by the Church Treasurer.

- Advantages

1. The general contractor's profit is eliminated.

2. The church controls the quality of construction.

3. It is easier to factor volunteer labor into this building process.

- Disadvantages

1. Coordinating construction work requires full-time participation of a person experienced in building. It would be difficult to retain such a person without a fee.

2. The church has no fixed maximum construction cost, only an approximation.

3. The savings realized (advantages - point \#1) are often offset by inefficient management, prolonged construction and purchasing at retail prices.

4. Banks may hesitate to make construction loans. 


\section{BUILDING PROCESS 6}

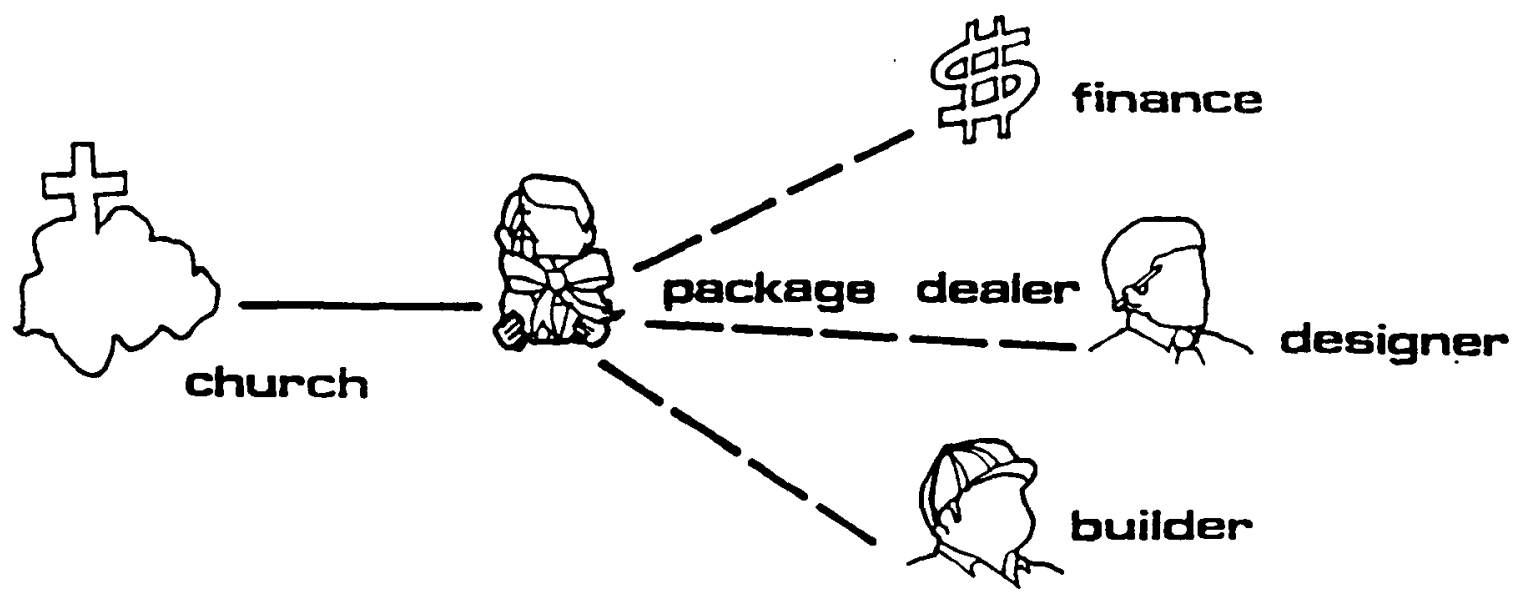

- The church buys a package deal.

- The "packager" provides plans and construction services.

- Often financing is handled by the packager as well.

- Advantages

1. The church receives planning and construction services through a siagle agent.

2. The packigle dealer can plan and build new facilities for a fixed maximun price.

3. A package deal often includes financing, further simplifying; the church's responsibility.

- Disadvantages

1. The package dealer's profit is made by re-using standard plans, (often with minor variations), standard materials and standard construction. There is no guarantee that the plans or finished construction will in any way relate to church program requirements, the site, the character of the neighborhood, or climate conditions.

2. The package price is determined by what the church can bear and and not on competitive bidding.

3. Since there is no agent for the church, they have very limited control over the quality of materials or equipment used in construction.

4. Most states require a registered architect's stamp on construction drawings. The architect employed acts on behalf of the package dealer and not necessarily for the owner. 


\section{SUMMARY}

In the construction industry, there are available numerous variations of these building processes mentioned. The six discussed are the more common procedures, yet each must be evaluated as to suitability for the local situation. In a changing market, it becomes essential to tailor the construction process used to the locale, the time available for building, and the availability and expense of materials and labor. No single procedure can be applied to every situation. Local architects should be able to assist the church in determining the construction process that best meets their design and construction criteria. 
APPENDIX I

SELECTING AN ARCHITECT AND CONTRACTOR 


\section{SECTION V}

\section{SELECTING AN ARCHITECT}

Architects give ideas three-dimensional form. They arrange and shape spaces to Eunctionally and aesthetically house program activities.

To become registered an architect has first earned a bachelor's degree in architecture from an accredited college, spent at least a three-year apprenticeship with a licensed architect, and passed a thorough examination offered nationally by the NCARB (National Council of Architectural Registration Boards). Through education and professional experience, the architect is best qualified to design the facilities that will accounodate your program needs.

As an agent of the owner, the architect can assist in program analysis and site selection, prepare schematics, design proposals, and contract documents, supervise bidding and monitor construction. Although there are numerous additional services provided by architects, the basic services are normally divided into these four phases:

\section{Schematic Design}

This involves introductory meetings, site analysis, program discussion and early design drawings with probable costs of construction.

\section{Design Development}

With approvals of schematics, the architect develops building plans and elevations, outline specifications and a revised statement of probable construction costs.

\section{Construction Documents}

Construction drawings, specifications, and contract documents are finalized. Bidding forms are prepared and cost estimates reviewed.

\section{Construction Contract Administration}

The architect assists the client in qualifying bidders, obtaining proposals, reviewing bids and awarding contracts. During construction, the architect reviews shop drawings, prepares change orders, and inspects the construction work to insure quality workmanship.

The timing and procedure for selecting an architect will be a key decision in the success of the building program. Architects are loost commonly selected after the Building Committee has prepared an architectural program proposal. There is an increasing tendency, however, to secure architectural consultant services at very early stages in the building program. 
An architect can prepare an existing facilities analysis for the Long Range Planning Committee and offer counsel to the newly appointed Building Committee by assisting in site selection, determining speze and program needs, and coordinating preparation of an architectural program proposal. These are expanded (or additional) services provided by an architect, usually on a fee basis, and covering only that work described in a negotiated contractual arrangement.

The church/school should not make a commitment for full architectural services to an architect providing expanded services, unless they are thoroughly satisfied with the work completed at that point.

There are three general methods for selecting an architect, the Direct Method, the Comparative Method, and the Design Competition Method. The particular method employed is usually determined by the type of client and project. For example, the direct method is most often used by the individual client undertaking a small project. The comparative method is more often employed by a group of people or Building Committee, and the design competition method is most frequently used for large civic and monumental projects. Although all methods are available in the consideration of any project, the great majority of architectural commissions are awarded as a result of either direct or comparative selection. Whether the selection is made by an Individual or by a group of people, the procedure follows three basic steps:

1. A review of qualifications and experience resume, together with photographs of executed work.

2. A personal interview to afford the investigator an opportunity to find out more about the architect's attitudes, philosophy, and personality.

3. An investigation of the architect's former clients and projects, preferably through visitation of buildings. This step will give an insight to the architect's ability and ingenuity in solving a problem and the degree of satisfaction attained.

\section{Direct Selection}

Am architect is selected on the basis of reputation, personal acquaintance or upon recommendations of former clients. As stated above, the architect's qualification should be reviewed, an interview arranged, and if possible, a tour of some of the architects's finished work planned.

\section{Comparative Selection}

Using the same three basic steps, the Building Committee determines a group of qualified architects and selects from this group the person who best meets their criteria. To develop a listing of qualified entries, the committee must first prepare a description of the project and then invite architects to submit applications. The church should supply the architect with this information: 
Name and address

General description of proposed facilities, including location, functions and areas required, etc.

Approximate project construction budget.

Approximate timetable for completion of project.

Any notes on proposed financing and ownership.

The church should request from the architect this information:

Type of organization: Individual, partnership, or corporation

Principals and staff: Name of principals, professional history, professional registrations and affiliations, key personnel, staff organization.

List of projects designed by firm in recent years. A recently established office will state the nature of previous affiliations and the degree of responsibility and various assignments, including type and cost of building, location, and construction dates.

References: Persons with knowledge of firm and work.

Supplementary material: Office policy on service during construction, business procedures, financial responsibility.

On the basis of the completed applications and personal reference, the committee narrows their choice to three or four applicants.

Interviews are arranged, as well as visits for reviewing their past works. Information to request from the architect during the interviews includes adequacy of over-all service, present work loads and availability, ability to work with the various agents of the owner, i.e., Plans and Construction Committee, Building Committee, and completeness of contract documents.

The final selection of the architect should be made on the basis of good standing in the profession, on creative and artistic ability, technical competence, and (very important), ability to cooperate with all those involved in the project.

\section{Design Competitions}

Although used infrequently for church facilities, design competitions usually generate the most creative architectural solutions. After compiling a comprehensive Program Proposal and establishing ground rules for the competitions, architects are invited to submit design proposals. The owner then has the opportunity to select the architect whose solution most satisfies program and aesthetic criteria. 
A competition is more expenstve and time consuming than other selection methods, and for these reasons has limited use. However, a properly disciplined design competition method can be the fairest and most effective way of producing the best design for a particular project.

Regardless of the method of selection used, the architect chosen should be a person in whom there can be a relationship of confidence and trust. When the dectaion to award the contract has been made, the owner and architect should conclude their negotiations with a written agreement that carefully defines their understanding This will confirm their negotiations and avoid misunderstandings at a later date.

\section{Fee Payment}

An architect is compensated for time, creativity, and expertise. The transition from an architectural program to a building design demands the architect's time, creative abilities and professional expert1se. Resource materials and consultants are secured. This may include professional engineers (structural, electrical, mechanical, etc.) design assistants, job captains, draftsmen, and office help. Other costs incurred are such office overhead items as rent, telephone, postage, insurance, registration fees, employee benefits and payroll taxes.

To meet these costs the following fee payment methods have been developed:

1. Percentage of project construction cost.

2. Multiple of direct personnel expense.

3. Professional fee plus expense.

4. Hourly rate

\section{Percentage of Project Construction Cost}

This method of payment for basic architectural services is the most commonly used, with the percentage figure generally determined by the local A.I.A. (American Institute of Architecture) chapter. The project construction cost used in determining the architect's compensation does not include the fees of architects and consultants, the cost of the land, rights-of-way, furnishings or other items which are the direct responsibility. of the owner.

In many situations labor and/or materials may be donated for construction. However, the architect's compensation is computed on an estimated project construction cost that includes this labor and/or materials at current market prices.

Any requested architectural services not outlined in the original owner-architect contract would necessarily be an additional 
expense reimbursable to the architect under a separate agreement. Payment of the percentage fee is generally on a monthly basis and in proportion to the amount of work completed. The following schedule is a guideline for total monies paid at the completton of each phase of the work:

Initial owner-architect contract

Schematic Design Phase

Design Development Phase

$35 \%$

Construction Documents Phase

$75 \%$

Bidding or Negotiating Phase

$80 \%$

Construction Phase

$100 \%$

\section{Multiple of Direct Personnel Expense}

When the scope of a project is not easily defined, as in renovation work, or when unusual procedures for awarding the construction contract are expected (see "Selecting a Building Process") the payment by a multiple of direct personnel expense becomes advantageous. The architect is paid the payroll cost of technical personnel working on the project, increased by an amount which covers indirect expenses, overhead and profit. Reimbursable expenses are in addition to these payments.

Payment schedule for this method of compensation is generally on a monthly basis as the work progresses and expenses build. Payments should only be made upon presentation of the architect's detailed invoices.

\section{Professional Fee Plus Expense}

This arrangement, similar to that described above, provides the architect with a negotiated, fixed fee plus the payroll cost of technical personnel working on the project increased by an amount that covers indirect expenses and overhead.

Payment for direct personnel expense and reimbursable expenses is made monthly as described for the multiple of direct personnel expense. The payment of the architect's professional fee is made on the same schedule as the percentage method.

Hourly Rate

Hourly rate arrangements between owner and architect are generally made for consultant services such as field visits, reports, opinions and expert testinony. The total time spent by the architect is to be reimbursed at the hourly rate.

Payment is made upon the architect's invoice. On short-term projects compensation is usually made in a single payment, while on larger, long-term projects, compensation can be extended on a monthly basis. 
Note: If a building project is suspended or abandoned in whole or in part, or the architect's services terminated, fee payment corresponding to the percentage of architectural service rendered is due and payable. Terminal expenses resulting from such suspension or abandonment are also due, and should be negottated between owner and architect.

When using standard A.I.A. documents for reference or as models for contract arrangements, ascertain that the document being used is the most current edition. 
SECTION VIII

SELECTING A CONTRACTOR

A general contractor has the responsibility of providing the equipment, labor and materials necessary to build the new facilities. Sub-contractors have the specialized tools and expertise to perform particular portions of the construction work. Working individually or together, the contractor and sub-contractor will construct the new work as the architect has drawn and specifled it in the construction documents.

Entering into a construction contract is the major step for the Building Committee and should be taken cautiously. With their architect, the Building Comnittee should work through these arrangements:

1. How to award the contract: by direct selection and negotiation, or by competitive bidding.

2. The contract system to use: single or separate contracts.

3. The type of contract: stipulated sum, or cost plus fee.

4. The examination of prequallfications of bidders.

5. The preparation of the bid documents.

6. The receipt of bids.

7. The award of contracts.

8. The execution of contracts.

Although the architect will be expected to assist to the greatest possible extent in working through these procedures, it is very important that the Building Committee (and the Plans and Construction Committee in particular) understand the process. This will allow the Building Committee to choose among the alternatives for selection and type of contract, and minimize the possibility of misunderstanding and dissatisfaction with the actual contractual arrangement.

Methods for Awarding the Contract

There are two basic methods of obtaining proposals from potential contractors. The first and most common is the competitive bid method. The second method of direct selection and negotiation has the advantage of being easily tailored for a particular situation.

Generally, the owner who employs the competitive bid method is primarily concerned with the completion of the project in accordance with the Contract Documents at the lowest possible price. By securing proposals from a representative number of bidders, the owner will

Ibid. 
usually be assured of obtaining a reasonable contract price consistent with prevailing economic conditions. To insure quality construction with the competitive bid method, adequate consideration should be given to the examination of prequalification of the bidders.

Concern with the competitive bidding method relating to responsibility, quality and time (bidding can be a three-six week process) may be minimized by awarding a contract through the direct selection method. As the term implies, the owner selects a contractor (or sub-contractors) after reviewing the requirements of the project and the capabilities of contractors who show an interest in performing the work. After selection, the owner, architect and contractor negotlate the terms of the construction contract in accordance with the project requirements. When the terms are satisfactory, the owner "awards" the contract.

The direct selection method is most useful in those situations in which construction is scheduled to begin before adequate drawings and specifications have been completed for the entire project.

The Contract System

Construction contracts may be entered into by owners through one of two basic systems: a single contract for all work, or separate contracts for each major division of the work.

With the single contract, one general contractor is selected and expected to provide or secure the necessary men and equipment to perform the total scope of the work. The general contractor in this arrangement has the responsibility for all aspects of the work.

Under the separate contract system, the general construction work is the responsibility of one contractor while the other aspects of the work (electrical, mechanical, etc.) are the responsibility of the other contractors.

It is to the advantage of the church/school for the Building Comnittee to weigh both these options, since one method may realize a cost savings over the other.

Type of Construction Contract

There are two basic types of construction contracts, or OwnerContractor Agreerents: Stipulated sum and cost of the work plus a fee (commonly referred to as cost-plus). The stipulated sum arrangement is the most widely used, particularly with the competitive bidding. In short, the contractor agrees to perform the work for an agreed stipulated sum. The most obvious advantage is that the owner knows from the start what the actual construction will cost.

The second arrangement, nore commonly associated with the direct selection of contractors, reimburses the contractor for the cost of construction plus a fixed fee for his services It is important to note 
that the amount of the contractor's fee be determined and included in the construction contract.

A variant of this agreement has the contractor perform the work for a fixed fee, but also guarantees a maximum cost of construction. Any savings below the guaranteed maximum are normally divided between the owner and contractor. The arrangement for his division of savings should be negotiated and then carefully articulated in the construction contract.

Examination or Prequalification of Bidders

To insure quality construction, the Building Committee should concern itself with these three factors:

1. The financial capacity of the potential contractor.

2. The quality of work performed by the contractor.

3. The experience level of the contractor.

The architect will be most familiar with local contractors and their credentials, but it is important that the Building Committee also be satisfied with the potential bidders. If the Building Committee is functioning in an Affirmative Action Role, it should seek total minority contractors and familiarize them with the project. This will give the committee an opportunity to eliminate potential problem areas, while allowing the minority for insuring their involvement in the construction.

Preparation and Receipt of Bids

These arrangement are normally handled by the architect, but again, should be reviewed by the Building Conmittee.

Awarding the Contract

When the bidders' responsibility has been determined by prequalification, the construction contract award should be made to the lowest bona fide bidder. When bidders have not been prequalified, the contract award should be made to the lowest responsible bidder. "Responsibility" should be determined by the criteria listed in examination and/or prequalification of bidders, and not on emotional or social prejudices.

Further, the owner has the right to reject all or any bid for good and sufficient cause. Particular care should be exercised by the architect and the owner to substantiate any refusal to award the construction contract to the lowest bidder.

Executing the Contract

The wording of the announcement of the selected bidder should be carefully drafted with the advice of counsel, since inportant legal 
consequences may attach to this notification. An improperly worded announcement could become a legally enforceable contract between the owner and the contractor, even though it was intended to award the contract at a later date. The General Conference Risk Management Service should review all contracts prior to their execution to determine if all Risk Management issues have been properly addressed.

In awarding the construction contract, the Building Committee should insist that the contractor provides a performance bond for the total scope of the work to be performed by that contractor (or subcontractor). The Building Committee has the right to require the selected bidder to furnish a Performance Bond and Labor and Material Payment Bond, prior to the actual award, if this is stipulated in the contract documents. Certificates of Insurance should also be in hand prior to the commencement of work by the contractor and/or subcontractors.

\section{Specialized Considerations}

There are numerous situations in which commonly practiced procedures for qualifying or selecting contractors will exclude other contractors. The intent of the following material is to minimize the obstacles that might prevent qualified builders from active participation in your building project.

1. The Scale of the Work

Often many smaller and minority construction firms are excluded from bid invitations or qualifications because of the scale of the project to be built. A successful approach that allows these firms to participate in the construction of projects greater than their capacity is "joint ventures." A joint venture essentially creates a new construction firm composed of the respective larger and smaller and/or majority and minority firms. Both should share in the responsibilities and the profits in proportion to the resources they bring to the project.

Sub-contracting and sub-sub-contracting are also arrangements that bring smaller and minority firms into the construction project.

Note: To insure minority involvement in construction, the Building Committee should direct the architect to stipulate this in the contract documents.

\section{Pajment Schedule}

There is a tendency of Building Committees to be less than prompt in making payments to the contractor for construction work. For a large construction firm this delinquency is easily absorbed in the normal cash flow. However, for a small firm that has a major cash commitment in a current project, slow payment can be disastrous. It becomes the necessary responsibility of the Building Committee, therefore, to make prompt payments, particularly with small and minority construction firms. The plans and construction comittee 
should be working with the architect to validate that construction is progressing according to the contract documents and on schedule. With their approval, each construction invoice should be met promptly.

\section{Ten Percent Retainage}

It has been common practice in construction to include a $10 \%$ retainage clause in the contract, $1 . e$. , to retain the last $10 \%$ of the total construction cost until all work has been completed to the satisfaction of the architect and the owner. Unfortunately, many churches/schools that have run low on bullding fund monies, have been either delayed or simply not paid the last 10\%. Again, a larger construction firm may absorb this loss while a smaller firm may need this last $10 \%$ to realize a profit or simply maintain financial solvency. The question raised then, that assuming full performance bonding has been required, is a $10 \%$ retainer clause really necessary? should:

In working with small minority firms, the Building Committee

a. Make a cormitment for prompt payment of all monies due upon satisfactory completion of work.

b. Consider placing the $10 \%$ retainer in escrow to insure that funds are available.

c. Consider omitting the retainer clause in favor of a full performance bond. The bond should stipulate that surety will arrange for complete construction in the event of default.

\section{4. line of Credit.}

One commonly encountered difficulty for the small or minority contractor is the lack of sufficient cash of line of credit to carry through the first construction payment. The Building Committee can assist by contacting the local bank to be used in financing the project and explaining its interest in promoting minority enterprise. This should assist the minority contractor in securing contractor assignment loans, which effectively provide the operating cash and financing for up to $80 \%$ of the contract. This operating cash allows the builder to cover initial expenses until construction payments are received. 
APPENDIX J

THE GARDEN OF EDEN A SANCTUARY 


\section{The Garden of Eden a Sanctuary? \\ Richard M. Davidson}

There are hints throughout Scripture that the heavenly sanctuary may have had a counterpart on arth even before the Mosaic tabernacle. In fact, the language of Genesis 1-2 points toward the Garden of iden as the earthly counterpart of the heavenly sanctuary! As we compare the portrayal of Eden with the escriptions of later divine instructions for the building of God's sanctuary/temple by Moses and Solomon, Irprising insights begin to emerge.'

1. Notice how the Garden of Eden was situated with an eastward orientation, as the later anctuaries (Gen 2:8; cf. Exod 36:20-30, 1 Kgs 7:21, Ezek 47:1).

2. God "plants" (nata $a^{\circ}$ the garden in Eden (Gen 2:8), and He will "plant" (nora $a^{c}$ Israel on His oly mountain, the place of His sanctuary (Exod 15:17; cf. 1 Chr 17:9).

3. The tree of life was "in the midst" (betwk) of the garden (Gen 2:9), and this is the precise term pr the presence of God "in the midst" of His people in the sanctuary (Exod 25:8).

4. The description of God "walking around" (Hithpacel of halak) is found only twice in the Old estament, once in connection with God's walking in the garden (Gen 3:8) and the other His walking in the idst of the camp of Israel (Deut 23:14 [Hebrew 15]).

5. There was a four-headed river flowing from the central location in the Garden (Gen 2:10), rallel to the river of life to flow from the sanctuary shown to Ezekiel (Ezek 47:1-12) and from the throne God as shown to John (Rev 22:1).

6. The precious metals mentioned in the Eden narrative (gold, bdellium, and onyx, 2:12) are entioned again in connection with the wilderness sanctuary (bdellium, only elsewhere in the Old estament in connection with the manna [Num 11:7]; onyx, upon the shoulder pieces and breastplate of the priest [Exod 25:7, 28:9, 20; 35:9, 27; 39:6, 13]; and gold throughout, overlaying the walls and icles of furniture in the sanctuary [Exod 25:9, etc.])

7. On earth after creation there were three spheres of space, in ascending degrees of holiness ("set artness for special use"): the earth, the garden, and the "midst of the garden." These three spheres are en again at Sinai: in the camp, the place where the seventy elders could go on the mountain, and the mediate presence of God where only Moses could go. ${ }^{2}$ They are repeated in the court, the Holy Place, d the Most Holy Place in the sanctuary.

8. Parailels may also be noted between the accounts of Creation as a whole and the construction of e Mosaic sanctuary. For example, there is a series of key verbal parallels: Gen $1: 31 ; 2: 1 ; 2: 2 ; 2: 3$ with cod $39: 43 ; 39: 32 ; 40: 33 ; 39: 43$, respectively. Just as "God saw everything that he had made/done asah]," "finished his work" and "blessed" the seventh day, so "Moses saw all the work" which the

'For more detailed discussion, see William J. Dumbrell, The End of the Beginning (Homebush, New uth Wales: Lancer Books, 1985), 35-76; Michael Fishbane, Text and Texture: Close Readings of Selected plical Texts (New York: Schocken Books, 1979), 12-13; Jon D. Levenson, Sinai and Zion: An Entry into Jewish Bible (Minneapolis, MN: Winston Press, 1985), 142-145; and Gordon J. Wenham, "Sanctuary mbolism in the Garden of Eden Story," Proceedings of the World Congress of Jewish Studies 9 (1986): -25 .

2See Angel Rodriguez, "Sanctuary Theology in the Book of Exodus," AUSS 24/2 (1986): 131-137.

Richard M. Davidson, The Garden of Eden a Sanctuary, (Andrews University,Berrien Springs, MI). A paper presented To North American Division Presidential Retreat, California 1996, (In my possession) 
sple "made/did [" $\overline{a s a h] " ~ i n ~ c o n s t r u c t i n g ~ t h e ~ s a n c t u a r y ; ~ " a n d ~ M o s e s ~ f i n i s h e d ~ t h e ~ w o r k " ~ a n d ~ " b l e s s e d " ~ t h e ~}$ reople for their labors.

9. Again, as the creation of the world is said to occupy six days (each introduced by the clause "And God said"), followed by the seventh day Sabbath, so God's instruction to Moses regarding the construction of the tabernacle in Exodus 25-31 is divided into six sections (introduced by the phrase "The Lord said to Moses"), followed by a concluding seventh section dealing with the Sabbath.

10. In Eden the work assigned to man was to "till" ("abad, literally "serve") and "keep" (Samar) the garden (2:15), and it seems more than coincidence that these are the very terms used to describe the work of the Levites in the sanctuary (Num 3:7-8, etc.).

11. Note also how the term for light (greater light and lesser light) used to describe the sun and moon in Gen 1:14-16 is elsewhere in the Pentateuch used only for the light of the menorah in the Holy Place of the Sanctuary (Exod 25:6; 35:14; 39:37, etc.).

12. In both the Solomonic and Mosaic Sanctuaries, the lampstand was a stylized almond tree (Exod

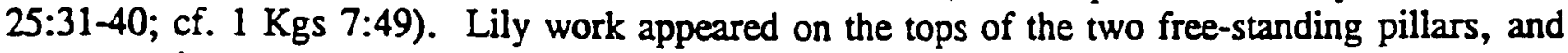
representations of oxen, lions, and more lilies and palm trees in the laver (1 Kgs 7:26, 29, 36). The references to the portrayals of nature in the sanctuary are fascinating. Carved in the Solomonic architecture--on the walls round about, and on the doors, were palm trees and open flowers (1 Kgs 6:29, $32,35)$. Could these artistic portrayals be representative of the return to the lost Garden? The earth's original sanctuary?

When we move to the post-Fall depiction of the Garden of Eden, we have confurmation of its ictuary character.

1. Before Adam and Eve's expulsion from the garden, God "clothes" (labas, Hif cil) them with "coats" (ktonet), Gen 3:21, and these are the very terms used to describe the clothing of Aaron and his sons (Lev 8:7, 13; Num 20:28; cf. Exod 28:4; 29:5; 40:14).

2. After Adam and Eve are expelled, in their sinful state they are no longer able to meet with God face to face in the Garden. But at the eastern entrance to the Garden (as with the eastem entrance to the later sanctuaries), we encounter cherubim--the beings associated with God's throne in the heavenly sanctuary (Rev 4-5; Ezek 1:10).

3. These cherubim are "placed" (Hebrew sakan), the same specific Hebrew verb for God's "dwelling" (sakan) among His people (Exod 25:8).

4. It is also the same root as for the Shekinah glory, the visible presence of God in the sanctuary. ${ }^{3}$

5. To this eastem entrance of the Garden, guarded by the cherubim with flaming swords, Adam and Eve and their children came to worship God, built their altars, brought their sacrifices; here the Shekinah glory was manifested as God came down to hold communion with them. ${ }^{4}$

${ }^{3}$ The name Shekinah does not appear in Scripture, but is used in the later Jewish literature. See also White, Patriarchs and Prophets, 349, etc.

"White, Patriarchs and Prophets, 62, 83-84. 
APPENDIX K

FINANCIAL WOES OF A CHURCH-BUILDING PROJECT 
'THE WOES OF A CHURCH BUILDING'

Halsey V. Peat, The Woes of a Church Building, to Carlyle C. Simmons, 19 September 1994, Letter (In my possession) 
When I arrived at the church the building program was in its fifth year and I was the third pastor to be involved in it. When the idea of the project was first conceived it was to provide a major community complex of church sanctuary, gymnasium and workshops at a cost of $£ 700,000$.

As a community project the complex would be open seven days each week providing facilities for job-training, youth groups, education and of course, church services. It was planned that much of the funding would come from the local government because of the high profile community-centered approach. In fact over $£ 300,000$ was given by the local government. The remainder of the project would be funded by the Division, Union, Conference and local church. To date, nearly $£ 1,000,000$ has been spent and a further

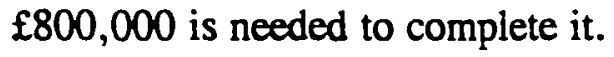

To complete the project, the workshops have yet to be finished and the sanctuary has to be built (only the foundations have been laid). The completed gymnasium has been serving as a multipurpose church for the past four years. Of course the old sanctuary and hall were demolished to make room for the new complex.

When the project began the pastor did not play an active role in its administration. The church established a committee which was led by two 'informed' members. The church trusted them to make major decisions on its behalf. Unfortunately the committee was not called to account until it was recognized that numerous problems had begun to occur. Members were busy fund-raising and costs had begun to spiral. The pastor was replaced by another with an MBA and thorough experience in the building trade. He attempted to arrest the problem and to return its administration to the church. There followed a major conflict involving those who had previously been involved in the project, the new minister, other members of the church who were against the first project managers, and finally, those who had been against the project in the first place.

Meanwhile some building work occurred but it was very slow and debts began to rise. On more than one occasion the Conference had to step in with money to pay off debts. The local church was now bitterly divided and I was asked to go there to attempt to stabilize the situation and give the congregation focus.

When I arrived at the church the problems I encountered were:

1. A divided church

2. A demoralized church

3. An unfinished project that had come to a stand still

4. No money to even continue the project and still facing increasing costs

5. I was lacking information concerning the project since its inception

6. Lack of church facilities because of the physical nature of the 'building site' we used for worship. 
On my arrival the church expected me to do something that would see the momentum of the project resume. I had not been prepared by my Conference. Nothing concerning the project or its nature and been given to me. I was totally unprepared. My previous church building experience was limited to a small extension to a church two years eariier. I was now faced with architects, surveyors and construction engineers and the supervision of major fund raising.

With the departure of the pervious pastor and some of those who opposed him, the church was mainly divided along the lines of those who not only opposed the program completely but would speak out against it, and those who supported it enthusiastically. The church was also demoralized because of the conflicts that had occurred over the building program. They had expended so much effort in fund-raising, had no more money and the completion date seemed so remote.

The strategy I used (if it can be called a strategy) was to ignore the pressures of doing anything relating to the building program. Instead I focused on building the church spiritually and to help it to see its purpose in terms of mission and evangelism. Meanwhile I attempted to learn as much as I could about the church building program. During this period I had to cope with those who constantly exerted subtle (and not so subtle) pressures to spend my time over the church building. I resisted and had to put up with the criticism that I was not interested in the church building.

After about eighteen months or so I felt that the church was now prepared to deal with the church building program again. However, the task appeared to be a mammoth one. With no money and no possible help from local government nor the Conference the church had to be motivated to believe that the projected could be completed. We decided to divide the work into smaller units. Each one being quite small gave the appearance of being reachable.

Fund raising was a major problem. The church was totally confused and divided about what was 'right' and what could not be done. Unfortunately the first elder, an influential and well-respected brother, opposed any form of fund-raising. It was not until he was not re-elected as an elder that a fund-raising committee was formed and set about laying plans. It was concluded however that the most effective method was that of sacrificial giving of time, means, and effort to raise funds. Targets were established and the church set to work.

Although the Conference felt that it had given and loaned more than it should have we approached it again. I enlisted the support of my colleagues in my geographical area (17 churches $\quad \therefore \quad$ They supported my request by drafting and signing a letter to the Conference. Additionally, they agreed to a plan of committing all their churches to supporting a common church building savings account. The idea is that all the churches would join to heip each needy church in turn. As the area treasurer I was responsible for drafting the program to present to the churches. When the Local church and Conference learned of this plan both were motivated to renew their efforts. 
I stated that the cost of completing the project is as much as the initial projected costs. Attempting to make this seem more manageable we asked the architect to see how the plans could be modified to reduce costs. Finally we were able to present to the church a package that could see them worshipping in their new church for only $£ 450,000$.

When I was asked to move, the local church was busy raising funds and the Conference had committed to help us with a significant, but not major, injection of funds.

\section{Impact on the church}

Now this is just a brief sketch of what has been taking place. The impact on the church has been devastating. Two years ago someone described the church as 'tired'. The building program had left it drained of finances, motivation, enthusiasm and a loss as to its mission. Evangelistically, nothing was happening, the church had an attitude of simply maintaining its existence. If they knew how events would have tumed out they would not have taken on such a major task.

Another impact on the local church concerns the relationship between it, the Conference and Union. At times the church felt abandoned and the help (with numerous conditions) now offered by the Conference is viewed by many as purely political. The trusting relationship that once existed has been severely strained.

In taking on such a huge building program I do not believe that the local church had thoroughly prepared itself for the task. Neither did it have the necessary skills in terms of management for the project. Those who were initially entrusted with its management were given far too much autonomy. On the other hand, when the church resumed authority over the project, the management became unwieldily with too many people involved in the decision-making process. It was difficult to strike the right balance between building committee autonomy and total church participation in decision-making. Also, for such a major financial undertaking, the Conference and Union did not actively engage in the planning until the problems had become very great, leaving the local church to think that it was struggling alone.

\section{Impact on the Pastor}

The impact on me, the pastor, was rather mixed. At first there was a sense of the enormity of the task and my lack of preparation for it. I was having to learn daily. For some members, their expectations of me to impact on the building program did not materialize soon enough and they found it difficult to have confidence in me. They failed to see my other qualities as a pastor and this made it extremely difficult for me to minister to their needs in a meaningful way. 
There was also the feeling of inadequacy. In the first year and a half, while basically ignoring the building program and trying to build the church spiritually, I felt that I was not really reaching the church because they were so set on the building. At times I questioned myself wondering if it was all worth it. It seemed at times that I was failing as a minister because the response to my efforts was so meagre and apparently unsuccessful. It was as if the measure of the minister was in the advancement of the building program.

Then there were the stresses relating to insufficient funds and having to face the church to explain why nothing tangible had been accomplished in six months. Or attempting to motivate and convince the church to part with more money to meet an unexpected bill. Other areas of stress arose from the conflict in time spent on the various aspects of the church building as opposed to time spent on other areas of my pastoral work. The members had high expectations in regards to my time because my predecessor only had the one church. When I was sent there, I was given an additional church with a building program of its own, albeit much smaller!

The impact was not all negative however. I acknowledged that the building program was a major problem that was not going to disappear one day. It was here to stay an I had to deal with it. I leamed to deal with one issue at a time and not to let it consume all my energies. It became just one of the major things that I had to face. As such I became somewhat resistant to negative comments and simply got on with the job in the best way that I could. I learned much in terms of the errors that had taken place before, and during my time there. I noted them carefully so that they would not happen again. Also, I gained much knowledge from my involvement with the architects and structural engineers. It gave me a wide appreciation for the work involved in planning and building a church.

\section{Tools}

I stated previously that I when I went to the church, I was totally unprepared. I believe that I would have been greatly helped if I had been provided with detailed information of the project and its history. Given that the church will always be faced with the problems of church buildings it would have been most instructive if the Conference had sent me (and other workers faced with church buildings) on some form of course or seminar that deals with the various facets of a church building program. This would include some form of exposure to reading building plans, learning some of the jargon associated with the building trade and general management of a major building program. Additionally, ministers with church buildings could also share their experience in terms of the impact that a building program would have on the church. It would be ideal it this was part of ministerial training but given that it would most probably be best appreciated later when the worker had been in the field, the Conference or Union should run programs like this so that its entire ministerial staff may be exposed to it. 
A useful tool could have been a prepared package containing ideas for managing a building program, problems to expect and how to avoid them, as well as guidelines on fund-raising (some form of definitive statement) and other useful tips.

Another possibility would be for the conference to provide a team of 'experts' to give advice and guidance to each worker whose church is planning a building program. Not only would there be a closer association between the local church and Conference but the minister would always have expert advice, even if he is a novice. Also, there would be a greater sense of continuity of a project if a pastor is removed to a new pastoral district before the church is completed.

Another advantage of having a team of experts is that the mistakes often made by each church in design, planning, administration and building would not be so frequent. These mistakes are made because each church usually undertakes a building program once in maybe fifty years, and then the knowledge gained is lost. Another congregation is left to make the same mistakes because knowledge is not shared. 
WINTER 1989

VOLUME $X$ NUMBER 1

Six Dollars

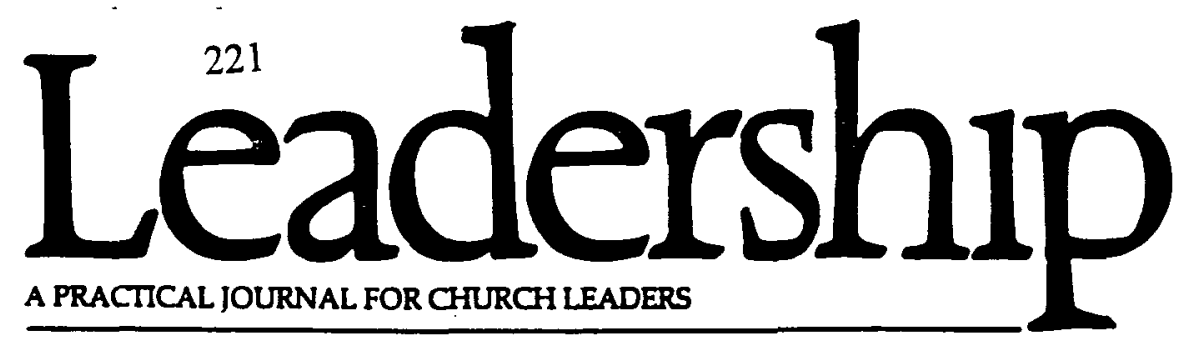

CRISIS

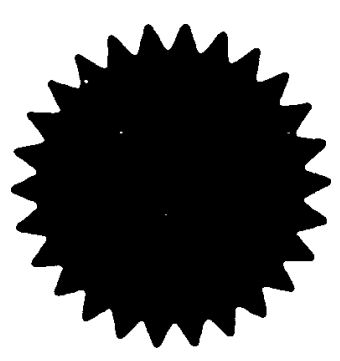

Inside Church Fights

An interview with SPEED LEAS

Spiritual Survival for a Forced Exit RODNEY CROWELL

Preaching through Personal Pain

DANIEL T. HANS

Tough Faith

BENJAMIN M. WEIR with DENNIS BENSON

52

The God Who Delegates

PHILIP YANCEY

64

When We Don't Get No Respect

DOUG JACKSON

Well-Focused Preaching

BILL HYBELS

Who Cares?

DALE S. RYAN

Pastor David or Pastor Solomon?

ROBERT L. MOELLER

When a Child Dies

CINDA GORMAN

After a Suicide

RANDY CHRISTIAN

Leadership Forum: The Coffer Crunch ARTHUR E. GAY, JR., H. ROBERT RHODEN, JAMES D. SMITH III, LLOYD STURTZ 


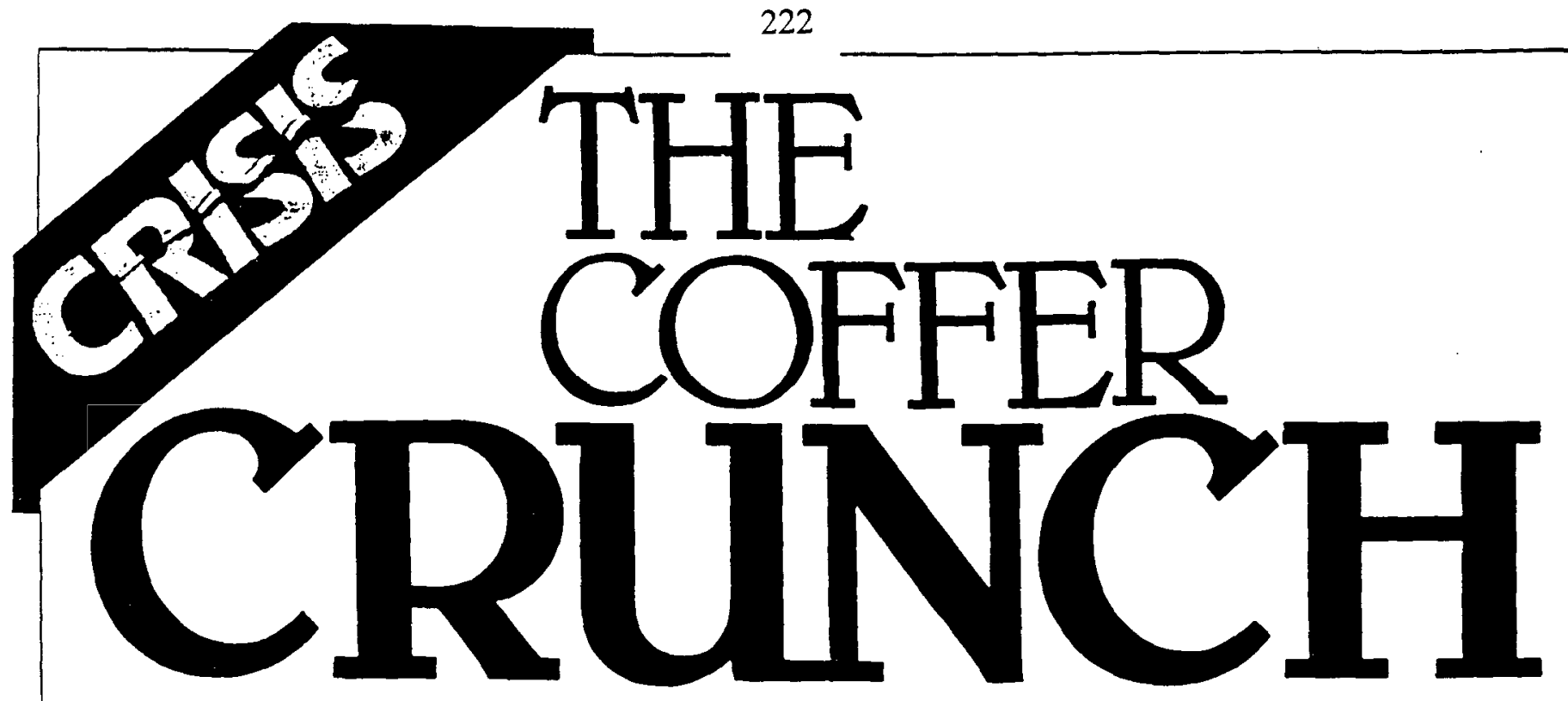

\section{What happens to ministry when money is in short supply?}

\section{A LEADERSHIP FORUM}

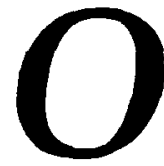

ctober 19, 1987, will forever be remembered as Black Monday in the financial world. The Dow plunged, like an out-of-control airplane, a record-scorching 508 points. In seven hours, investors lost some $\$ 500$ billion in equity values. Smaller brokerages were forced out of business. Traders were let go. And now, more than a year later, according to reports, smaller investors still have not regained confidence in Wall Street.

What happens when a local church experiences a similar financial downturn? What exactly does ministry mean when a church faces a fiscal crisis, whether moderate or severe, and what's the pastor's responsibility?

LEADERSHIP posed those questions to four pastors who have experienced money crunches of varying kinds. As an introduction to their discussion of the underlying issues, here is each pastor's account of how his church found itself in a hole.

\section{Aborted Bequest}

Jim Smith

Elim Baptist Church

Minneapolis, Minnesota

Late in 1983, a former parishioner at Elim approached my predecessor to say: "My family has deep roots in this church. And now that I'm beginning to think about retirement, I'd like to build the church a new building - whatever it costs - provided you furnish it."

Plans began, I came to the church, and by July of 1987, the building's roof and walls were completed. The inside, though, had a long way to go.

Then the donor suffered a

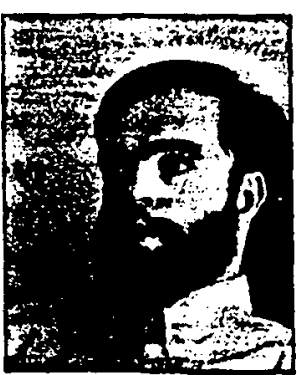

major financial reversal and informed me, "I have to cap the gift."

That left our urban-neighborhood congregation, attendance around 300 , with signed contracts and debts totaling aimost $\$ 700,000$. Without any clue it was going to happen, we inherited a debt three times our annual budget. If the work stopped, we could be sued for breach of contract. We weren't sure there would be enough money for any staff. We came within days of the project being shut down.

\section{The One-Two Punch}

\section{Lloyd Sturtz \\ Chippewa United Methodist Church \\ Beaver Falls, Pennsyivania}

My former church, Grace United Methodist in Franklin, Pennsylvania, had grown to an attendance 
of 450 on Sunday morning, which was more than our sanctuary could handle, and we began thinking about building. At that time, a member told me, "I'm expecting a major legal settlement shortly, and I'd like to give half a million dollars toward a new building."

We had some money set aside, and with that gift promised, we bought property and began site preparations. When the foundations were laid and walls were going up, the major donor called me at home. "I'm about to receive the check," the person said, 'but l've made a decision. I'm not going to give you the money up front. I'm going to put it in my will, and you'll get it when I die." This donor was only 35 years old.

That left us with roughly

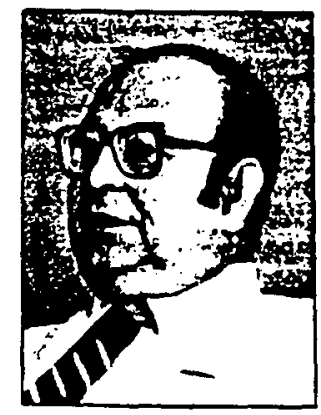
$\$ 600,000$ indebtedness, which would have created a cash-flow problem but still have been manageable.

However, six months later we learned that Joy Manufacturing - the largest employer in Franklin - was laying off half its management staff. In the next nine months, community unemployment hit 25 percent. We lost three hundred of our eight hundred members as they moved to find work. And most of these people were active leaders and liberal givers.

The church hadn't experienced financial difficulty before, but now we had to decide each month which bills we'd pay. We wrestled with which ministries would go, and eventually we had to drop our Christian day school.

\section{Changing-Demographics Slump}

\section{Art Gay}

South Park Church

Park Ridge, Illinois

Our situation isn't as dramatic as some of the others', but it's current. South Park Church is about

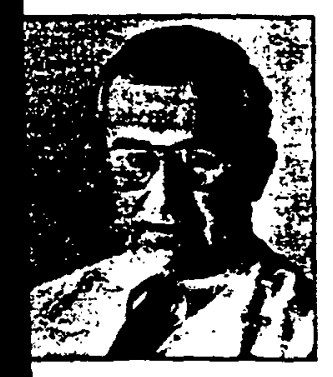
50 years old, and without faith promises or pledges, it has always paid its bills and been able to expand its ministries.

But the game has changed. Many of the church's long-time "angels" are now being called home or retiring to Arizona. In our urban/suburban Chicago area, many of the younger families can't afford to live here unless they have two incomes. And the younger people we do keep aren't accustomed to tithing. They like to give to projects - like co-sponsoring an Indian church in Chicago - but they don't get as excited about ongoing operations.

As a consequence, we're currently in a cash flow crisis and $\$ 100,000$ behind budget. We can't afford to replace one pastor who left, so we've had to cut back ministry to young singles, which is a growing area for us. As we build our budgets for next year, we're looking at no raises - and probably cutbacks - in staff salaries and ministry programs.

Though we're a church with no debts, we have few resources. The county just approved our plan to put up a two-story educational building, which we need because we have many young families with children. But the people causing the expansion can't pay for it. We have one year to start building, but we're several months into the year and have no fund drives going because of our current situation. So the building may not happen.

\section{Botched Building}

\section{Bob Rhoden \\ West End Assembly of God \\ Richmond, Virginia}

In the late seventies, when attendance at two morning services reached about five hundred, we decided we needed more space. We designed a

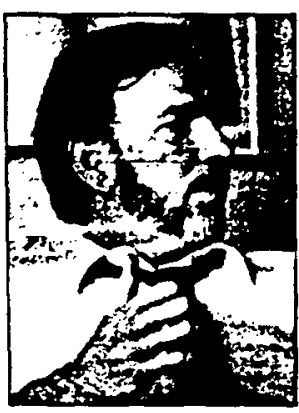
simple, multipurpose building. Our philosophy was that you don't borrow, and we thought we'd spend $\$ 250,000$ on a payas-you-go basis.

Meanwhile, three problems developed in the congregation. One was theological; we had to deal with the "name it, claim it" issue. A second problem was governmental; we were changing from a congregational to a more presybyterian polity, and that created a power struggle. And the third problem was economic. We discovered we had a crowd but not a church. There was no common vision, and people were not excited about giving.

We decided to proceed with the building anyway. As we got into it, though, costs soared to $\$ 400,000$, and so in midstream we had to switch from pay-asyou-go to borrowing. Before, we had taught "It's God's principle that we not borrow," and now we were asking people to take a loan. That created a loss of confidence in me and the other leaders.

Meanwhile, the county charged us $\$ 150,000$ for drainage work we hadn't anticipated, and the building ended up costing $\$ 980,000$. 
When the building was completed, there wasn't enough parking, and the air-conditioning didn't work on opening day, a hot September Sunday, so we had the doors open. Plus, the building flooded on one side, so sometimes members had to mop.

Soon, we didn't want to answer the telephone because of contractors. We Lorrowed $\$ 500,000$ on the first mortgage and tried, unsuccessfully, to raise the rest of the money. We had to take bonds for an additional $\$ 205,000$.

People stopped coming to church to find out what God was doing in people's lives; they came to find out how much we owed. At one meeting, three people demanded we put the church into receivership. Another night, a church meeting to discuss the problem nearly turned into a brawl. One man challenged another, "You want to step outside and settle it?"'

Leadership: Whew! You and your churches have been through the wringer. Yet you're here talking about it, alive and well. What happened?

Bob Rhoden: First, we held a "Day of Victory" on Easter of 1980, in which we tried to raise $\$ 50,000$. We received $\$ 17,000$, which represents a lot of sacrificial giving, but all we could think was, We came in $\$ 33,000$ short of our goal.

We learned something through that: never look to a one-time event as a way to restore the damage from a long process. It took time to get into the mess, and it will take time to get back out. You have to say, "God, we trust the process that's going on here."

After a lot of thought, I stood with the other leaders one Sunday morning and said, "We have made a lot of mistakes. We have blown it royally." We didn't try to blame anybody else. We said, "We ask you as a congregation to forgive us for what we've done wrong. We don't have all the answers to this, but if together we can find an answer, we'll go on."

It was gut wrenching to stand before five or six hundred people and say, "I've blown it." But the people recognized it was sincere, not a manipulative move, and they came forward, wept with us, and told us they forgave us. That didn't solve all our problems, but it changed some attitudes.

Jim Smith: Keeping relationships strong is critical. $I$ had to ask, "How can we keep from fighting ourselves, from attacking segments of the church, from scapegoating?"' It's natural for people to wonder whether someone could have seen this coming.

But as we talked and prayed through our feelings, we were able to do the practical things we needed to

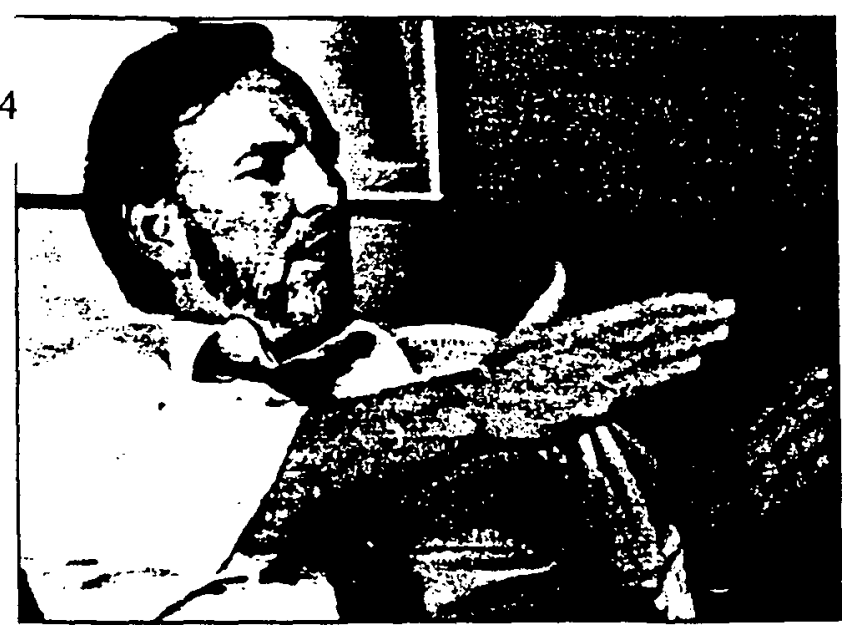

ts a temptation during crisis to become a fixer rather than

\section{a builder.}

\section{- Bob Rhoden}

do. We began a faith promise program and obtained a line of credit from the bank, and the people responded generously. The budget jumped 30 percent in one year, but we've gradually moved from a full-blown crisis into a cash-flow crunch. We aren't able to support a full-time associate, and there's austerity, but we're making it now.

Lloyd Sturtz: We had to make some tough decisions through agony and prayer. It wasn't easy closing down our Christian school, and we lost a family over it. But from those decisions and courageous giving by the members - tithing of their severance pay! - the church has gradually climbed into the black.

Art Gay: The only solution to our situation has been to redefine ministry success. It isn't based on noses or nickels; it's based on being faithful with what we have. Whether or not we build a building or have as much staff as we need, ministry will continue.

If I don't get a raise, I remind myself that raises are not a given; they're a privilege. Joanne and I are ready to take the lead in this. Going backward in compensation is not failure. What hurts, though, is when people move to other churches with great numbers and finances and then view us as unsuccessful. We have to keep saying. There's another standard by which we want to be measured: faithfulness.

Smith: When a crisis hits, the minister has to take 
the lead. We made some cuts, and so in three years my salary has gone backward. But that doesn't bother me; I'm not a martyr. It's just that if you're going to ask people to sacrifice, you have to cinch down, too. Some of our dear people mortgaged their homes to make sure we didn't lose the ranch. Together we made the decisions and paid the price. And as a result, we had a deeper sense of ownership and of God's desires to use the building in ministry.

Rhoden: What helped turn us around happened after that time of repentance before the congregation. My associate and I were brainstorming one day, and we concluded: "We're in such a mess, we'll never solve all of it. We ought to go help somebody eise." We recommended the church send twenty people to the Dominican Republic to build a church. The twenty paid their own airfare, and the church raised $\$ 12,000$ to help with the project. The group built not one but two churches, and suddenly we began to develop an identity.

Our attendance dropped to about 350, but internally we rounded the corner. From that point on, five different people gave us large gifts. They said, "We want to give this out of conviction, not because we feel any pressure." When we gave up worrying about ourselves and started helping others, the whole situation changed.

Leadership: Looking back, do you think you could have forecast your various crises? If so, what would you have done differently?

Smith: In our case, no. Who would have guessed a multi-millionaire would struggle with finances?

Complicating the situation is that when I came as pastor, in July of ' 85 , the oars already were in the water, the boat was wet, and the rowers were sweating. I tried discreetly to ask some questions: "Do I have any latitude in this building project? Is there any elbow room to talk about the nature of the gift or how it's applied?"

The response: "Realistically, not at this point."

Leadership: If you had been able to influence the initial stages, what would you have done?

Smith: Set a clear definition of the size of the gift. The gift was open-ended, which was the way the donor preferred it, and the donor and building committee acted in good faith. But without a set amount, all we could do was say, "Here's what we would like to see in the building. Do you think this is okay?" And the response would be, "That seems reasonable." But when the crisis hit, we didn't even know the exact extent of our indebtedness.
Sturtz: We could have been more realistic if we had watched the economic downtum everywhere else in the country. It didn't hit the Franklin area until two years after other areas. We had a two-year reprieve, but we just didn't pay attention.

We Christians tend to say, "We live by faith; God's going to take care of us." That's true, but we'd better look closely at what the business community is doing if we're planning new construction.

Rhoden: If I could go back, I'd gather people in the real estate, development, and construction businesses. As a pastor, I haven't been trained as a contractor or real estate agent. In a recent building program we just completed, we did gather such a group, and that team kept us on track.

A second thing $\mathrm{I}^{\prime} \mathrm{d}$ do is make sure the congregation owned the vision. In our first building program. we talked about "We're gonna pay for this as we go," and they all stood and applauded. But they just didn't give.

Leadership: The applause meant, "They are going to pay for it, not I."
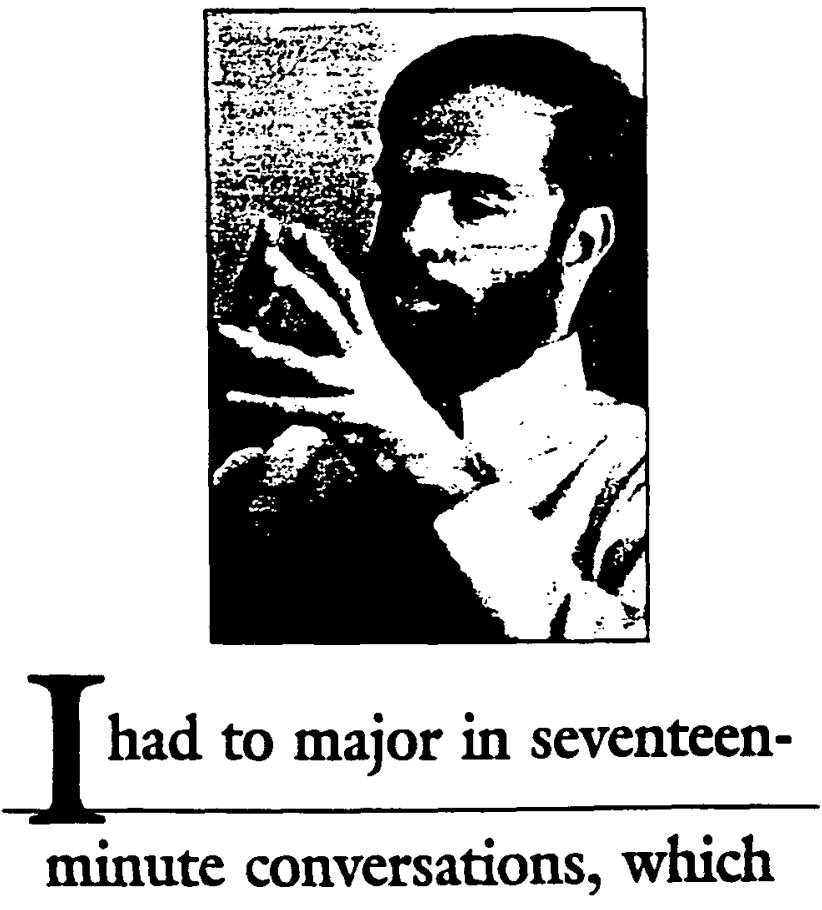

usually began, 'Pastor, I've got

a concern."

- Jim Smitb 
Rhoden: Exactly. There has to be some criteria by which you can determine whether people are ready to take the next step. For instance, in this current project, we said, "Before we take step one, we're going to pay for the land, which will cost half a million dollars." The money came in for that, and then we knew the people were behind the project.

Third, I'd set a realistic goal for the cost of the building and stick to it.

Leadership: What happens in a congregation when money is tight? What symptoms do you notice?

Gay: Embarrassment, surprise, self-doubt, anger, acrimony at meetings. In the past, our congregation felt there was nothing we couldn't do. To find out we can't do some things we'd really like to do is earth shaking. People want to distance themselves from that.

One of the roles of pastoral leadership is to identify the mood of the congregation and describe their

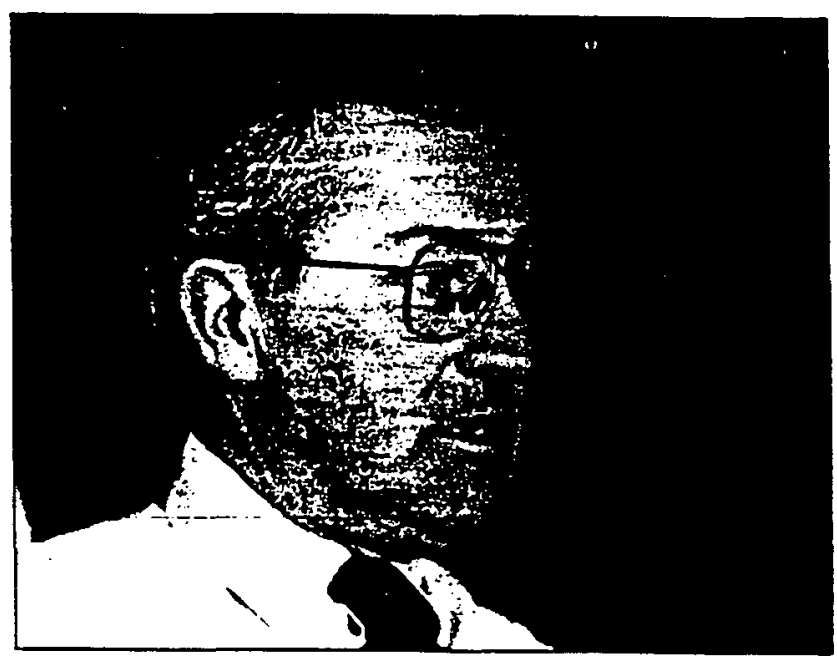

nside the gut of every pastor

is the feeling that if he's good at

what he does, there will be

enough resources to carry on the

work of the church. feelings. That's part of shepherding, of helping people through the grief process.

Leadership: So your counsel would be to talk about the crisis directly?

Gay: Yes, from the puipit. In my case, I was given the assignment: "Now, Pastor, we're in trouble. Get out there and preach those stewardship sermons." (Laughter) Seriously, the leaders said, "It's your responsibility to articulate the vision of the church, and we're in a critical situation." So I talked about our position clearly and directly. The bottom line was, "Realistically, when we begin a new fiscal year, the church will be at this financial position, and the congregation will determine the level of ministry. And that's okay. God hasn't left us, and I have no intention of leaving unless you know something I don't." (Laughter)

I went on to say, "My sense of success isn't attached to money; it's attached to faithfulness." That was important for people to hear, because people expect that when giving goes down, pastors yearn to leave. And the fear of desertion is a strong emotion. So I want to articulate the church's vision, communicate the people's feelings about the crisis, but then say, "However this comes out, we'll still be here ministering together."

Smith: Something I'd add about communicating publicly during a crisis is to wait until you have the facts. The Sunday in July after I found out we had a problem, I didn't say anything. By the end of the summer, I had an idea of our debt. By early September our leadership was working on a strategy. Not until October could I write a newsletter article for the congregation with full detaiis.

Leadership: What did you say in that article?

Smith: I affirmed the generosity of the benefactor and the diligence of the building committee. Then I said we'd received word that the generous gift would have to be capped, and this meant it would cost over $\$ 600,000$ to complete the project. I admitted $l^{\prime} d$ felt anger, fear, and the temptation to blame others. But now, I said, I'm ready to move to the next stage: finding the Lord's solution. Finally, I strongly urged people to attend a Sunday meeting where the financial realities would be explained in detail.

Rhoden: To me, the timing of when you say something publicly is important. If I stand up and speak during the announcements, it's heard on one level. But if what I say is part of the sermon, it has a higher value. So I spoke about the crisis right before I 


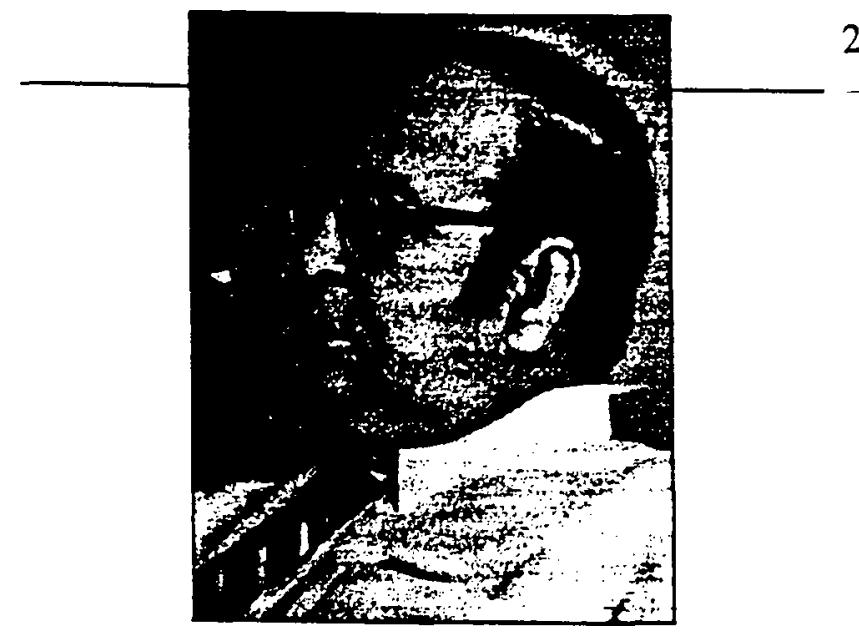

wondered, Are you sure you

\section{heard the Lord correctly when he}

\section{said to build?}

\section{- Lloyd Sturtz}

preached. I'd say, "I'm going to talk to you for just a few moments as family." Why take the lowest part of the service to say what is important?

Leadership: Your approach also places whatever you say in a spiritual context.

Rhoden: Right. It says, "We're not talking about mere business, folks. We're talking about the kingdom." We elevate what we say by when and how we say it.

But I also think it's important to resist the temptation to let the crisis enter all your preaching. I really felt a tension: $A m$ I going to preach out of this pressure I'm feeling, or am I going to preach out of God's anointing?

Sturtz: In retrospect, I would change the way I described the problem. I said repeatedly from the pulpit, "We don't have a financial problem; we have a spiritual problem. If our people were as spiritually committed as they ought to be, we could easily do this." I'd never say that again. That was a disaster.

Leadership: Because you accused people of lack of commitment?

Sturtz: Because it wasn't altogether honest; we did have a financial problem. The leaders kept coming to me and saying, "You've got to tell them we need more money to pay our bills."

I'd say, "That's not what we need. We need more commitment. If our members would tithe, we could pay our bills."

And they'd say to me, "Lloyd, you're an idealist. The reaiity is we're facing $\$ 10,000$ in bills this month that we haven't been able to pay."

Leadership: So if the situation presented itself now, how would you talk about it?

Sturtz: I would be honest enough now, I think, to say, "Unless we come up with this amount of money, we're not going to be able to meet the budget." Then I would say, "I believe we will be able to pay this bill if the spiritual issue of commitment to give is taken care of." I'd put the spiritual and financial together.

Rhoden: I made the mistake of talking about our financial problem every week. It would have been better to pick the first Sunday of the month and say, "I want to give you a report on how we did last month." That way, people get a feeling there's some relief. But if you talk about a corporate problem every week, you fatigue people, and soon the corporate problem overshadows personal needs, and ministry deteriorates.

Leadership: Besides the public presentations, what other aspects of ministry do you need to emphasize during a crisis?

Smith: I tried to anticipate people's reactions and questions. "How did this happen? Is it anybody's fault? Could there be some mistake?" The congregation seemed to experience denial and all the other stages of grief. In addition, people began to ask broader questions: "Where do we go from here? Does this building really represent us, or is it just one guy's dream?"

As a result, 1 invested an enormous amount of time in answering phone calls, initiating conversations, and saying, "No, the way you heard it isn't exactly the way it was." There were so many stories going around, and I had to make sure the straight story was being heard.

Gay: I haven't changed my time allocation. Crises of church discipline consume many days or weeks or months, but during a financial crisis, if I'm going to carry on the rest of ministry, I can't focus just on that. Probably if you'd ask my financial chairman or board chairman, they might say "Art should be more concerned." But deep down they have the attitude, and it's been articulated to me, "You spend the time in the Word and head the ministry team. Share with us the other concerns, but we don't want you bleeding off your energies toward this. Ministry has to go on. Otherwise we'll have nothing here." 


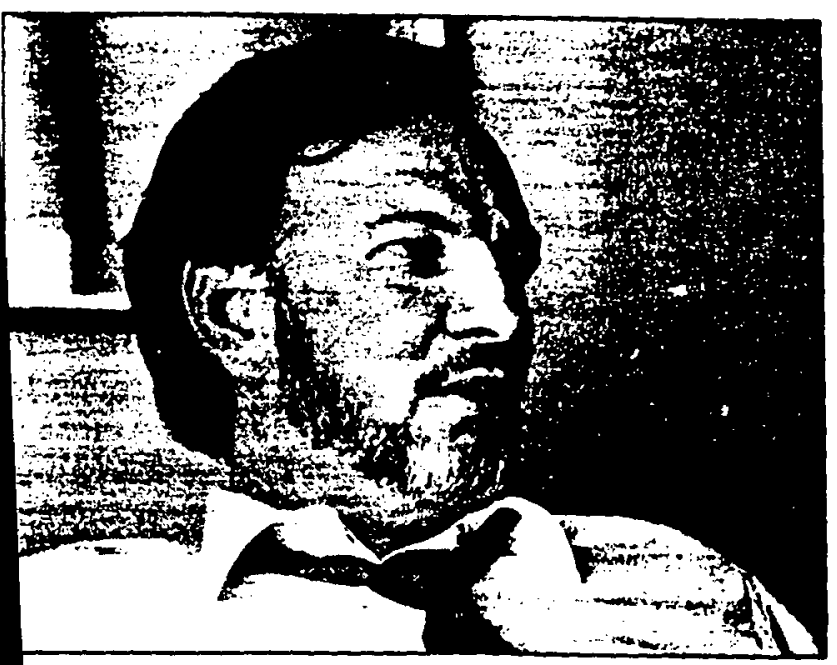

t was gut wrenching to stand efore five or six hundred people and say, "I've blown it."

\section{- Bob Rhoden}

urtz: I had to spend extra time deciding what id of ministry we could afford. I looked at the tom line and knew we were going to have to est ourselves of some programs. I had to go to the urch and say, "If the church is going to survive, have to continue our youth program and our dren's program. Sunday school, worship, prayer, Bible study have to continue. But we can do ay with the concert series and the special speakers. d the school will have to go."

takes time and discussion and prayer to make kind of decision, to honestly interpret the congation's willingness to support a program.

ith: I had to monitor where my people were. he lay people gave an immense amount of time expertise to handle the problem, and I got ferned they might burn out. Other people seemed even in touch with what was going on, and so l'd "Wouldn't you like to get involved, in prayer in offering constructive alternatives?" So I spent either calming people down or waking them up.

den: I found myself doing a lot of damage fol, trying to deal with people's feelings. Somewould call and say, "I'm upset about the way has been handled," and I'd get drawn into that.
Some ugly things were said about "supporting his vision," and I had to work through those.

Sturtz: You hear some amazing stories. For example, "Lloyd's building a monument to himself."

Leadership: How do you deal with a charge like that?

Sturtz: Smile and say, "Boy, if you ever get the chance to build a monument for yourself, I hope you get to go through what I'm going through." (Laughter)

Leadership: What are the temptations for a pastor in the midst of a financial crisis?

Gay: To cut and run, to sell used cars.

Rhoden: Oh, yes. I saw what the situation was doing to my family, and I thought, I don't need this. Let somebody else deal with it. But that would have been reacting rather than responding.

Sturtz: Another temptation is to let anger build. When that member decided to put the gift in a will, I felt angry and frustrated. I thought we had been shafted.

Rhoden: It's a temptation during crisis to become a fixer rather than a builder. As a pastor, you're the builder; you're responsible for the long haul. But when a money crunch comes, you want to put a Band-Aid on the situation.

Looking back at our "Day of Victory,' I realize I was trying to fix the problem in a hurry. If I could do it over, I would say, "Folks, we owe a lot of money. We're not going to fix this in one Sunday. It's going to take a process, and we're going to build over time until we come out of this."

Another example of "fixing" things is that we stopped putting out a weekly bulletin. People came one Sunday, and there was no bulletin. I had to explain, "There wasn't enough money for it." I would never do that again. That creates such a strong negative statement, and we were saving something like $\$ 13$. But in a crisis, all you can think of is solving a problem rather than making the best decision for the long haul.

Smith: I know what you're saying, but at times you're forced to apply some Band-Aids. With only a few days' warning, we had to draft a lean budget for the bank to examine before it would extend a line of credit. It had zeros for certain staff people. We had warned them that might happen, but we 
didn't have time to give them official notice. Later, one associate resigned and then de-resigned in the midst of this. When you have situations like that, you have to do a lot of extra mustard plastering. I had to major in seventeen-minute conversations, which usually began, "Pastor, I've got a concern."

Is that putting on Band-Aids? It's not just damage control; it's ministry.

Sturtz: I faced another temptation because I felt guilty. If I had not been interested in reaching the community, in helping the church grow, we would never have needed the building. I wondered, Are you sure you heard the Lord correctly when he said to build? I felt so guilty about it that finally I went to a psychologist friend and said. "I'm dying inside. Something's wrong with me. Talk to me." We talked for hours. and I finally realized I wouldn't do anything differently were I doing it over again. I'd want the money in the bank before I turned a spade of dirt, but I believe in people. I believe they want the church to grow and to do the ministry of the Lord.

But it took me a while to get there. There were times when I considered buying a $\$ 2$ million keyman insurance policy and doing away with myself to get the church out of its crisis. I know I could never have gone through with my intentions. But there were times I contemplated that, because I hurt so much for the congregation and felt so guilty.

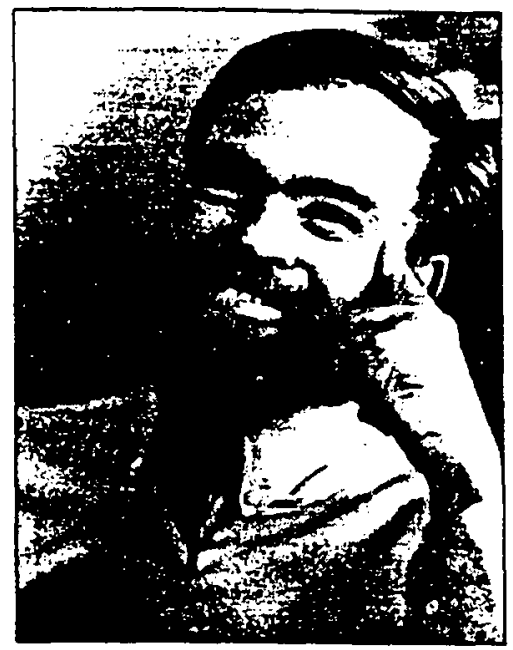

\section{spent time either calming}

people down or waking them up.

- Jim Smith
Leadership: Now that you have some distance from that situation, do you think accepting blame was a realistic assessment? Did the congregation hold you responsible?

Sturtz: No the congregation never blamed me.

Leadership: Even if a pastor has no responsibility for the crisis, how much is the pastor responsible for getting the church out of it?

Gay: You want an honest answer? Inside the gut of every pastor is the feeling that if he's good at what he does, there will be enough resources to carry on the work of the church. It's based on the old saying, "If you do God's work in God's way, you'll never lack God's supply." But what happens is that when you don't see God's supply, you think you must not be doing God's work in God's way. Yet I see people ministering in the middle of Chicago and in South India who do God's business in God's way and yet have no resources, financially speaking.

My responsibility as a pastor is to nurture a climate in which people can free their resources to support God's work. I do that primarily through teaching the Word of God so that conviction - internal motivation by the Holy Spirit - takes place, rather than external motivation.

Sturtz: In the United Methodist Church we're ordained to "Word, Order, and Sacrament." We stress the Word and the sacraments, but the responsibility for order, administration, also comes to the pastor. So when something goes wrong, for whatever reason, it's the old Harry Truman statement: "The buck stops here."

Leadership: During the money crunch, what gave you hope?

Sturtz: In the midst of the crisis, friends and colleagues would come by. Some would drive a couple of hundred miles just to say, "We want to take you to lunch; we want to pray with you." And that made it possible for me to put my arm around people in the congregation and pray with them.

Rhoden: Adversity has a way of bringing out optimism in some people. Both of my parents were killed when I was two; a drunk ran over them. I don't have any brothers and sisters, and my grandmother brought me up in below-poverty-line conditions. But she always told me, "God loves you and will be with you. Don't measure who you are as a person by your outward circumstances." I've never forgotten that. During the worst of our situation, something insicie 


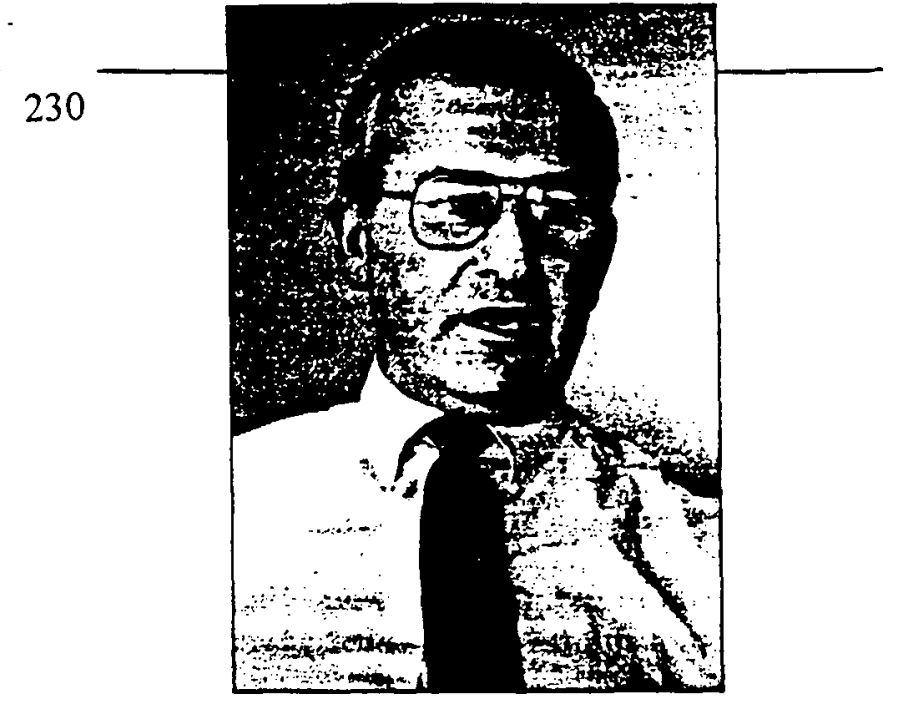

said. God is sovereign. It's bad, and I don't know if it'll ever get better, but I think it will, and I'm gonna keep on going.

Gay: I ask myself, What is this self-pity that says I have to have funding at a certain level or feedback that I' $m$ success, zul? Maybe good theology does result in good psychology after all.

Leadership: What do you wish you'd known going into the crisis that you know now?

Smith: I would like to have known it was going to happen, to have a few months' lead time to soften the impact. But when I look back, I realize the Lord was preparing us spiritually for some of this, tuning us to be responsive to him.

Gay: That crisis is part of life. If I presume to be an undershepherd, why should my experience be different than the Chief Shepherd's, whose life was a series of crises? I expect the current crisis to pass at some point if God so wills. And I expect another period of crisis to occur entirely beyond my ability to imagine it. Life is like that.

Sturtz: I would like to have grasped going in what my colleagues reaffirmed for me: You are not in control, Lloyd, but God is, and you can trust him.

Maybe I also needed to know the faithfulness of the congregation. Had I looked at what they had done previously, I could have seen they weren't going to desert me.

Rhoden: It's important to keep in mind that crisis is not all there is. That's hard to do when you're in the middle of one.

Gay: Right; crisis is not where we dwell. It's a great privilege to be part of the fellowship I serve.

In preparation for our discussion today, I tried to recall past difficulties, and though we've had some, I had trouble remembering the details. The painful situations are overshadowed by recollections of $\mathrm{min}$ istry. Maybe I have the spiritual gift of amnesia. (Laughter)

Leadership: Are there any benefits from a time of shortage?

Gay: After the acrimony of the business meeting a

Deople expect that when giving goes down, pastors yearn to leave. So I want to say,

"However this comes out, we'll

\section{together.”}

\section{- Art Gay}

few weeks ago, people began to come to prayer time. Our prayer meetings have been better than they've been in the last ten years, because people realize prayer's the only answer. I've been praying to the Lord for years, "Do whatever you need to do to get people to pray." If it's taken this situation to bring it about, then I accept what's happening. Crisis causes people to be the most spiritual they've ever been.

In my own life, each of the crises through which our church has gone has made me dig deeply into the only thing I have, and that's my call from the Holy Spirit. When I was a kid, 7 or 8 years old in LaSalle Street Church in Chicago, I committed myself to serve in the pastorate. In every crisis I've dug deeply on that, and I've found that call to lead a church to be substantial and secure.

\section{$\%$}

There is nothing so weak, for working purposes, as this enormous importance attached to immediate victory. There is nothing that fails like success. 
APPENDIX L

\section{RECIPE FOR A BETTER KITCHEN}




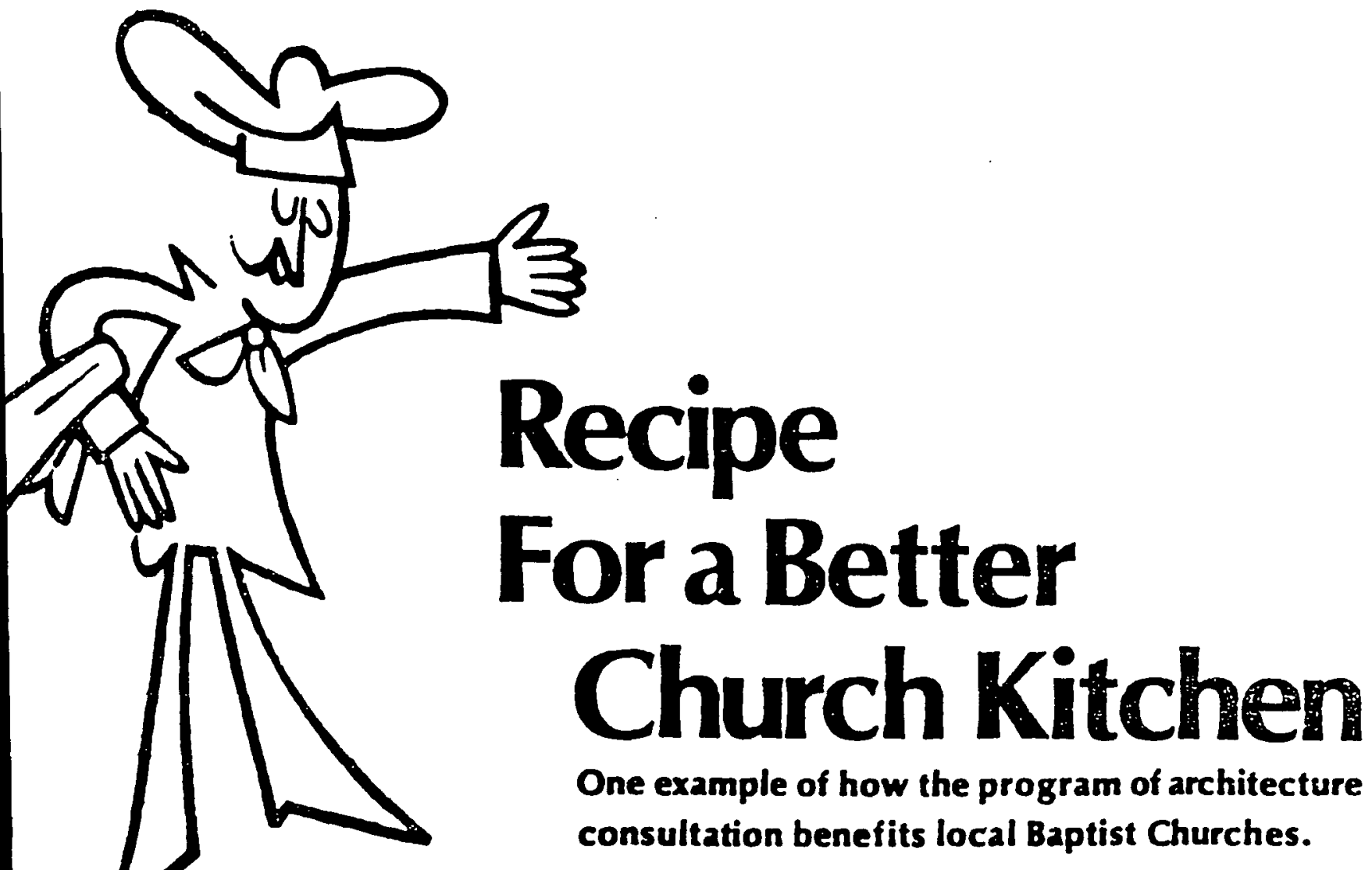

It is well if some parking space is nestby for the convenience of those working in the kitchen.

The kitchea should bave easy access to water, sewer, and utility lines, and should be near an interior corridor of the building. It should be directly adjacent to the dining area for convenience in serving food, and receiving disbes back from the dining area. It is preferable not to locate the kitchen across the corridor from the dining area. However, in some cases. it is desirable to have a serving line along the corridor near the dining area. Avoid large openings directy into the dining area which could tranemit dintracting sounds.

Space. How much space is needed in a kitchen for it to be adequate? In this case, "adequnte" would mean enough space to provide for storage and refrigeration of food, preparation of food. cooking equipment, service ubles or counters, washing and storing of dishes and cooking uremils and pace for worker trafic. The space would also relate to the type and frequency. of meals usually cerved and the average number of people served. To ascure adequate space when planning a church kitchen. the size of the litchen should be equal to 20 to 25 percent of the dining spece if complete meals are to be prepured. If a large aumber of menis are eerved froquently, on a regular sobedule, additional ipace will be needed for tornge and refrigeration. If meals are catered or partially pre-prepared, leas space and equipment will be needed.

ArenNaruert. The kitchen should be planned and designed so that food and diabes move in an assembly line arrangement from the place food is received into the kitchen, through the preparation and cooking procesen, to the counter or serving table and then to the dining room tables. After the meal, the assembly line process sbould continue by receiving dishes and leftover food from the dining room, scraping food from plates and disbes, dishwashing and storage, and gar. bage deposited in wate cans and dispensed. The food preparation, eerving. washing and storing operations should be so designed that they do not interfere with each other.

For sanitation and for the convenience of workers, it is good to provide a hand washing basin in the kitchen. This should be located near the food preparation area.

EQU1PMENT. In the majority of situstions. commereial or institutional-type equipment should be used in church kitchens where full meals are prepared on a regular basic. For small kitchens, which are used very little, a more general-purpose type equipment may be rufifeient. In most esere, residential-type equipmeat is oot adequate.

The type and number of pieces of 
equipment is a church kitchen are de- mmined by the frequency of use and the age number of people to be served. 1 cot practical for a church to plan I equip a kitchen for unusually large neetings which occur only a special cecasions. For example, id chirch movid! pot find it practical, or wise, to provide kitchen and dining area for anociainnal or state meetioge that may come - the church oece in a two- or three-year seriod. Most churches alwo find it im. practical to plan and equip a kitchen and fining area to care for a very large meetng of the church, such as a stewndship dinner, that may occur osly once a year. for such oceasions it uxually prove nore practical to lease a school cafeteria of other public dining plece. The liteben Ind dining aress of the church should bo lanoed to care for only the pormal, vernge, week-to-meek peods.

/entrutnon. A well planped ventilation ystem not only adds to the comfort of hose working in the kitchen, but th is iso important in kecpine odon and rease fumea from spreadion to other reas of the church, or accumulating in he kitchen. Proper ventilation also hne dircet bearing on the enteiency of the ling. heating, and cooking equipmeat he kitchen and dining area.

Kitchen ventilation may vary all the ay from an open windor to a complex xhaust sytem. Cold, outuide air in winfr months. and duat and insects in sumher months usually make an open wimow undesirable for vestilation.

In many churches, an otherwise wellesigned kitchen exhaust sptem is made effective because the requirement for exh air is overiooked. The exhauswed air hust be replaced by in approximately qual smount of freah air from some purce. If the freab air supply is inado uate. a low air presure will develop is se room. This can enuse roverse dratu bwn the vent flues of tos applinnes, ereby impairing their eneiency.

For best results the freal ats supply ould be acrom the room from the ex. cust sysicm. If the freah alo mppiy b ought in near the exhaus aydem it ill inly lue pulked back out withour meilalling the kitchen. It in hetrer if the supply in near the floor.

In a properily ventilated kitches the t. odor-filled air in exhanuted and ro aced by clean, freah air once evory two three minuter or tweaty to bhirts a per hour. A rood exhaux orden

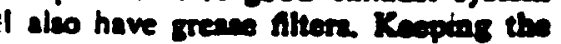
sere flters chens will ax down os the ager of meas aren axd blp inenes pper veotilation. A word of earrion

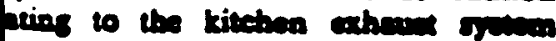

should be made. Be sure to exhauns the sir directly outside mther than up through a second or third floor of the building. If it is exhausted through a sysem going throuch a muli-level building, the danger of a srease fire spreading to otber floor is sreatly incresined.

Sunrtatnos. To proted the bealth of the people being revied, the kitchen must be kept ensitary by frequent inspections and thorough cleaniog. This menns thet eanily cleaned surfaces such as a quarry tile toor, ceramic tile wils, and stainless teel equiponeat mux be used. Care mux be taken to keep the kitchen free of in. secer, rodentes and leftover food. All outride doors and windows sbould be ereened. Gartare should be removed prooupty.

Acournos. 'Acourica is mot pormally thou he of in relation to auditoriums and edveational space, but it is aleo an important fector in planning cburch kitebem. The kiteben should be 20 desiroed and equipped thint noises do not intertere with proceeding in the dining room or other areas of the church. To belp accomplinh this the ciling and upper wils should absorb sound, but not moir turs. Thare are vinyl-coated ceiling tiles and wallboard on the market now that will barically meet theas requirements.

Thare are ato foam gine blocks on the martet that are cound-abeorbing but are not affected by moisture. If the foam glase is uned it should be hung on the walls, out of the food preparation atea. in panels over cabivets and other areas where people will aot come in contne with it.

To further aid in cound control, the conuruction of floors, walls, and doors should be designed to help prevent the transmission of sound to otber areas of the church. Careful planning should also be given to the placement of heating and cooling dues since these can easily serve as sound tranmitters to other areas. Plastic-conted dish racks, instead of metal, will also belp keep down noise.

Additional help may be secured from consultents of local commercial kitchen supply hounes. pan and electrieal com. panies and from your ate univeraities.

Regrint trom

The Buptast Prooruk
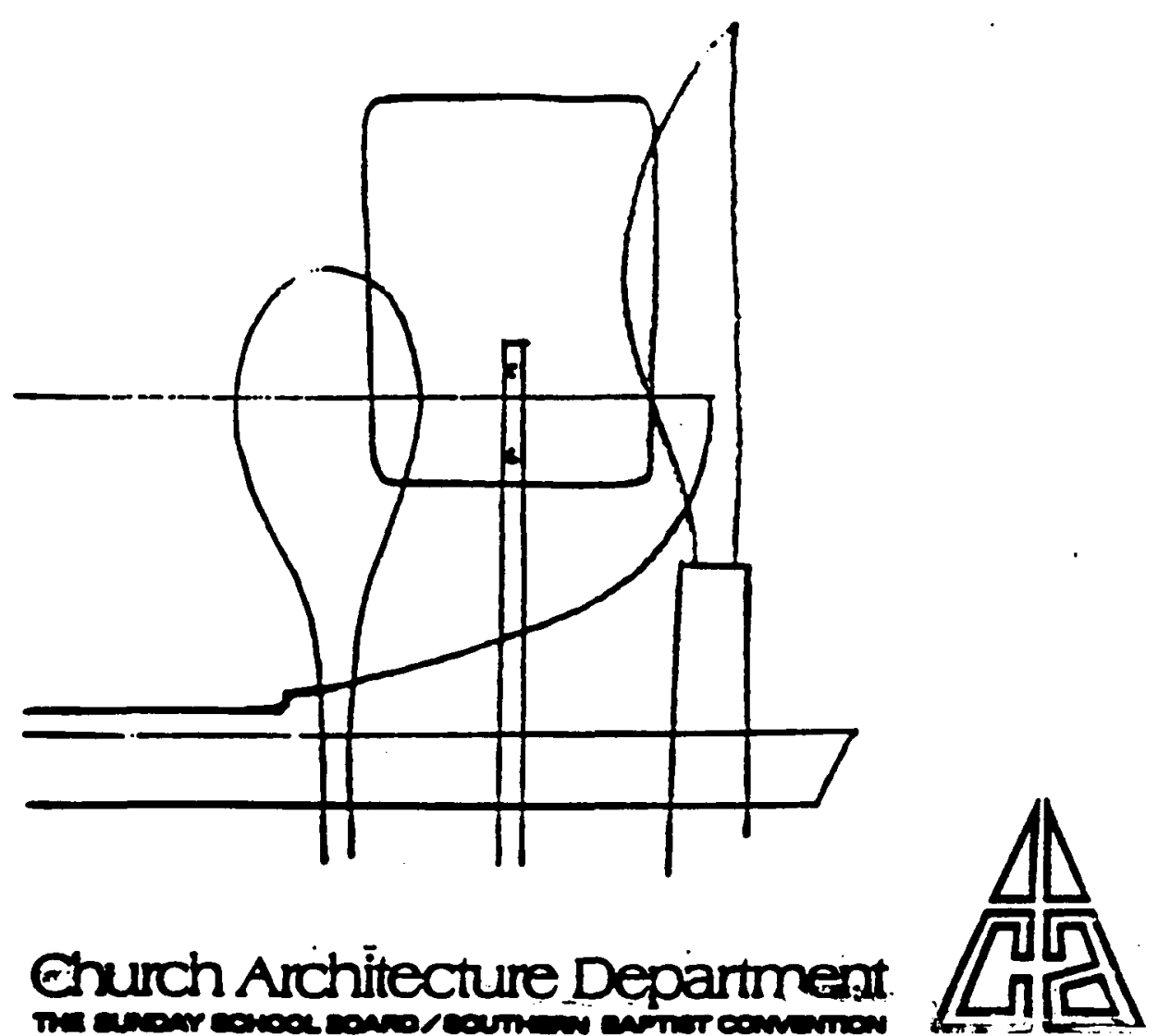
APPENDIX M

SETTING UP A PARKING LOT 
THE BOARD OF CHURCH EXTENSION \& HOME MISSIONS OF THE CHURCH OF GOD, INC. P. O. Box 2069, Anderson, IN 46011 Phone 317-644-2555 

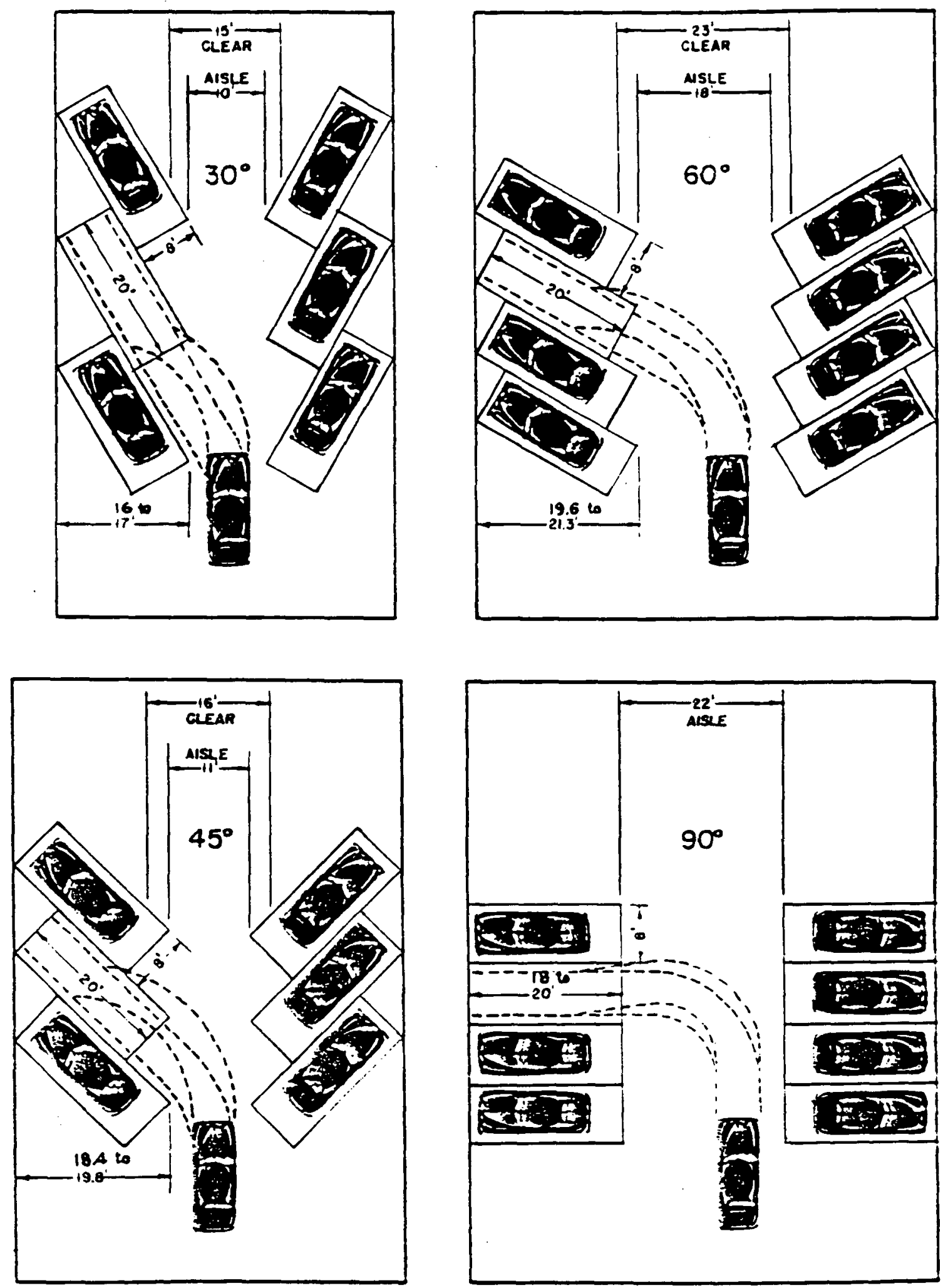

AISLES AND SPACES REQUIRED

FOR VARIOUS ANGLES OF PARKING 
APPENDIX N

BUILDING PERMIT/GUIDES--BERMUDA 
Department of Planning Building Control Section

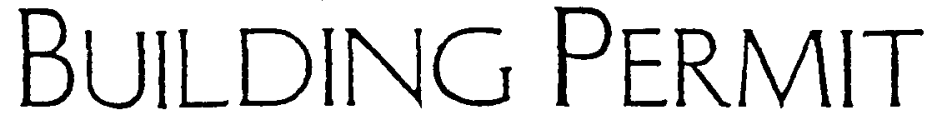

\section{INFORMATION SHEET CONSTRUCTION DOCUMENTS NEEDED FOR THOROUGH PLAN REVEW}

\section{BUILDING REVEN}

Complete arcititectural/structural plans

Site plan, including distance to lot lines

Soil boring and geotechnical recommendations report, inciucing the description and bearing value

Structural calculations or other substantiation of stuctural performance

General specifications

Fireresisiance rated assembly specifications

\section{COMPLETE REIIEN}

3 sets of the documentation needed for a Building Review Complete Mecranical plans and specijications

Complete Plumoing plans and specifications

Complete Eiectical plans and sipecitications

\section{SPRINKR EP REMEN}

Complete Sprinkler plans and calculations, including design calculations, current flow test and material/equipment specincations

\section{PREIMINARY BUILDING REVIEN}

Arcinitectural/engineering design development drawings indicating size of the building, Use Group, and Type of Constuction. Drawings to include building plans and sections with means of egress, fire separation assembly locations and fire protection systems proposed

Soil boring and geoterchnical recommendations report

Foundation structural calculations

NOTE: Consiruction documents should be signed, sealed and dated by the registered design professional in accordance with the professional registration laws. in which the project is to be constucted. 


\section{NOTICE OF INTENTION TO DEVELOP LAND \\ IN PURSUANCE OF REGULATION 4 OF THE DEVELOPMENT AND PLANNING (DEVELOPMENT APPLICATIONS PROCEDURE) REGULATIONS 1970}

Application has been made to the Development Applications Board for permission to carry out the following development:

Name of Application:

Application Number:

Address or Location

of the Proposed

Development:

Description of the

Proposed Development:

Zoning of Land

to be Developed:

Any persons wishing to object, may within 14 days of the date of this publication, lodge with the Department of Planning, Government Administration Building, Parliament Street, Hamilton, any objection to the proposed development. This application is available for inspection at the Department of Planning during normal working hours. Letters of objection should state any interest which the objector(s) may have in property nearby, together with an address at which notice may be served on their objections. Further details of procedure for objection are set out in the above mentioned Regulations.

Date: 199 


\section{Development Applications Board}

clo Deparment of Planning, Government Administration Building 30 Parliament Street, Hamition HiM12, Bermuda

Telephone: (809) 295-5151

Fax:

(809) $295-4100$

LETTER OE CONSENT FORM

Date:

Dear Sir/Madam,

Planning Application Number (If Available)

Address of land

to be developed:

Proposed Development:

I, the undersigned:

(Full Name - Print)

am the OWNER OI

House $\#$... Street

(Add=ess)

- Parisin

the property to the * north/south/east/west of the applicant's property.

I have seen drawings (reference $\frac{\mu}{\pi}$ )

Drawn by:

showing the above mentioned proposal.

I do hereby confirm that I have no objection to the works being carried out within * $10 \mathrm{ft.} / 15 \mathrm{ft}$. of my boundary as shown on the above drawings.

signature $\ldots \ldots \ldots \ldots \ldots \ldots \ldots \ldots$

* delete where appropriate 


\section{Department of Planning}

Government Administration Building

30 Parliament Street, Hamilton HM12, Bermuda

Telephone: (441) 295-5151

Fax: (441) 295-4100

INSPECTION REQUEST HOT-LINE 297-7828

BUILDING CONTROL
TECHNICAL DIRECTION 95-02

TO: All Agents/Applicants/Contractors/Building Material Suppliers

FROM: Building Official DATE: 18 September 1995

SUBJECT: Summary of Basic Code Requirements for Residential (R-3)

Developments and Checklist Used by Staff for Building Permit Applications and GDO's.

Ofter, applicants have asked us what needs to be done, and the type of construction drawings necessary to receive approved permits. We have developed a series of public handouts that describe various concepts which are available at our front desk. They have also been distributed to libraries and post offices, etc. To assist you further, and to respond to the most widely asked questions, I am summarizing the basic code requirements to assist you in determining what you need to plan for. While the summary is not all inclusive, and deals with single family dwellings, it is representative of the general 1991 Building Regulations.

\section{R-3 APPLICATION CHECKLIST}

1. Site Plan (3 sets) - Locate proposed building on your site showing setback dimensions to the property lines to satisfy planning requirements. If applicable, locate your proposed well and septic tank. Proposed buildings cannot be installed over existing well and septic tank, or any underground facilities. Give dimensions of building including dimensions of any garage, porch, deck, etc.

2. Construction Plans ( 3 sets) - Plans are required on all new residential structures including new single family dwellings, additions, and other remodeling and repair jobs.

- Floor plan - show overall dimensions and label rooms, locate windows, doors, etc.

- Elevations - show outside views of what the building will look like when completed. Heights of ceilings, doors, etc., for internal work. 


\section{(2) Room Sizes}

- Ceiling Heights: Habitable rooms other than kitchens, bathrooms, storage and laundry rooms, shall have a ceiling height no less than 7 feet 6 inches. All other shall have a ceiling height of 7 feet measured from the lowest point of the ceiling.

- The maximum projection of beams and girders below the required ceiling height that are spaced no less than 4 feet on centre shall be 6 inches.

- Floor areas - minimum room size of one habitable room shall be no less than 150 square

- feet.

- All other rooms except kitchens shall be no less than 70 square feet.

(3) Stairs (Guards \& Handrails)

- Minimum stair headroom clearance, 6 feet 4 inches.

- Landings every 12 foot vertical rise between floors.

- Treads and risers - 8-1/4" rise maximum; 9 "tread minimum (nose to nose).

We recommend $7^{n} \times 11$ " - safer and more comfortable.

- Landings shall not be less than the required width of the stairway.

- Landing guards and handrails - only one handrail is required on stairs less than $\mathbf{4 4}$ inches wide.

- Height - handrails shall be at least 34 inches high; no more than 38 inches.

- Width of stairs - 36 inches minimum.

- Spiral stairs - cannot be used as means of egress except in buildings of R.3.

- Guard rails - R.3 - 36 inches minimum with a 6 inch opening between immediate rails capable of withstanding $200 \mathrm{lbs}$. concentrated load at any point.

- Doors - shall be 28 inches clear minimum and 6 feet 6 inches high.

- Swimming pool protective barriers and gates; 48 inches high minimum; 4 inches maximum openings between railings and all elements. Doors and gates must be selfclosing and latching.. 
7. All electrical, metal and mechanical equipment around swimming pools must be bonded and grounded (see Article 680).

8. Conductor from meter to panel must be AGW \# 4 copper wire for 100 amp service. $2 / 0$ for $200 \mathrm{amp}$ service. (120/240V, 3 wire single phase).

(7) Plumbing

1. Bathrooms must have 1-WC, 1-LAV, 1 Bath/Shower, $3 \mathrm{fc}$ of light with outside ventilation (window or mechanical).

2. 1 Kitchen sink, 1-auto clothes washer connection.

3. Hot and cold potable water. All solder, pipes, fittings will be lead free ( $8 \%$ maximum).

4. Sewage systems shall not cross over potable water tanks and drainage piping offset of 3 feet. Minimum underground pipe size is 2 inches, 12 to 18 inches below grade.

5. All fixtures will be vented to the outside air, 12 inches above roof.

6. Each fixture connection to sewer must have a liquid seal trap.

7. Individual fixture clearances must be provided as required by Article 12 (BOCA Plumbing Code).

If you have any questions, please give us a call, or ask our staff, and we will provide a response in a positive and prompt manner. Thank you for your continued support in building code matters, and your positive assistance in making Bermuda construction operations and building safety consistent and progressive.

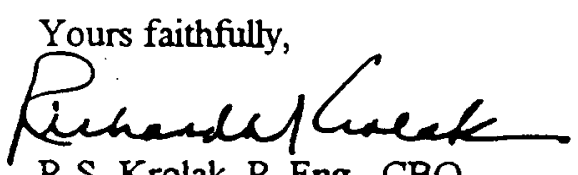

R.S. Krolak, P. Eng., CBO

Building Control Officer

RSK/caw

Enc: G.D.O. Information Sheet

c.c. Chief Fire Service Officer

Chief Environmental Health Officer

B. Rowlinson, Director

Building Control Staff

Section Heads

Enforcement Officer 


\section{BUILDING CODES}

How Do They Help You?
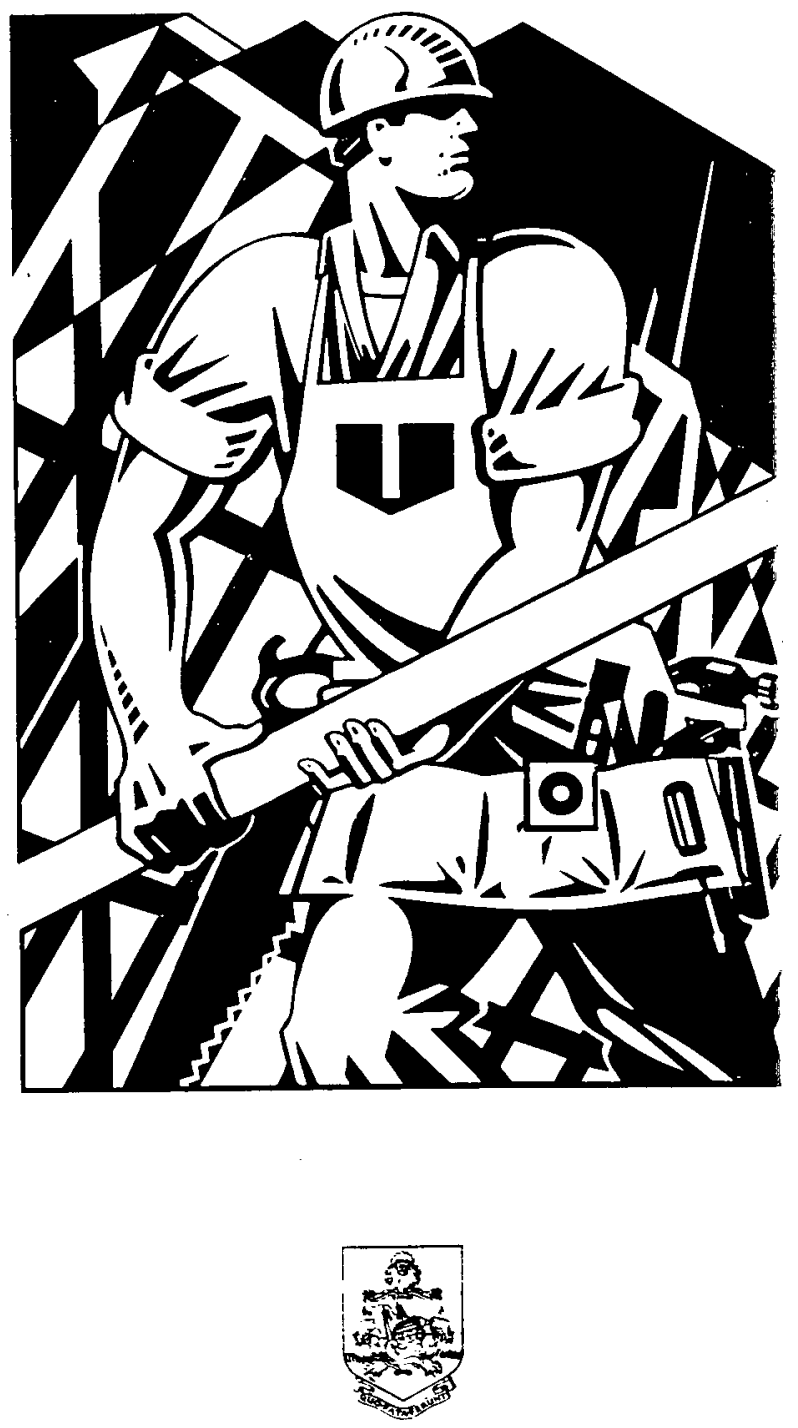

Produced By The Department Of PlanNing 


\section{OS How do Codes Help You?}

A Code is a collection of requirements which pertain to a specific subject, and which regulate specific practices.

A Building Code is a collection of technical requirements (such as the placement of exit signs and smoke detectors) and regulate practices (such as the design, construction or remodelling of buildings).

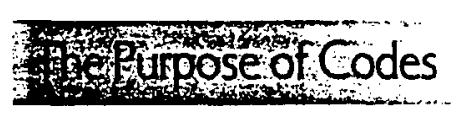

No matter what the individual activity may be construction. property maintenance, fire prevention. electrical, or plumbing - all codes have the same purpose:

To protect public health. safety and welfare by requiring safe construction.

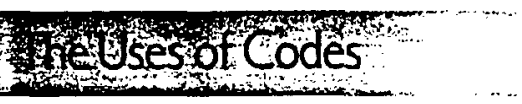

3 Codes are adopted as laws or regulations by Covernments. Once a country adopts a National Building Code as law. the structures in that jurisdiction must be built to conform to that law.

- Codes become part of the permit and inspection processes. Once a code has become law, officials and inspectors need the code to ensure compliance with the law. Inspections made during construction verify that the code has been followed.

- Codes provide standards for the design, construction and maintenance of homes and businesses. Codes are used by architects, engineers, contractors, builders and materials manufacturers to ensure safety, economy and consistency of construction. As a home or business owner, you have a substantial investment which can be seriously jeopardized by code violations.

\section{A Codes Protect the Public's Health. Safety and Welfare}

We all need protection from fire. structural collapse and general deterioration of the structures that surround us: our homes, schools. stores and manufacturing facilities. Building Codes provide protection by reducing potential hazards to building occupants.

\section{$\triangle$ Codes Keep Construction Costs Down}

Codes provide uniformity in the construction industry. This uniformity permits builders and materials manufacturers to do business on a larger. international scale than if construction was unregulated. Larger scale allows cost savings which are ultimately passed on to the consumer.

\section{A Codes Provide Consistent Standards in Construction}

Codes establish predictable and consistent minimum standards which are applied to the quality and durability of construction materials.

\section{A Codes Contribute to the Well-being of a Community}

The preservation of life and safety as well as the maintenance of property values over time are a direct result of the application and enforcement of Building Codes. 
Each major phase of construction must be inspected by the Inspectors to make certain the work confor to the Code, the Building Permit and the Approved Plans.

The person responsible for the construction project must request each inspection. Normally 24 to 48 hours advance notice is required.

If an inspector finds that some work done does not conform to approved plans, the inspector will advise (and provide written notice) that the situation is to be remedied. If the violation is serious, a stop work order may be posted until the problem is resolved. Another inspection may be necessary before work is resumed.

\section{Receive Certificate of Occupancy}

When code compliance is determined, the Building Olficial issues a Certificate of Occupancy. This - certificate is the formal document which marks the completion of your construction project and gives you permission to occupy your new or renovated building with the knowledge that it has met the sa. standards in your community. 


\section{BUILDING PERMITS}

Why And How?
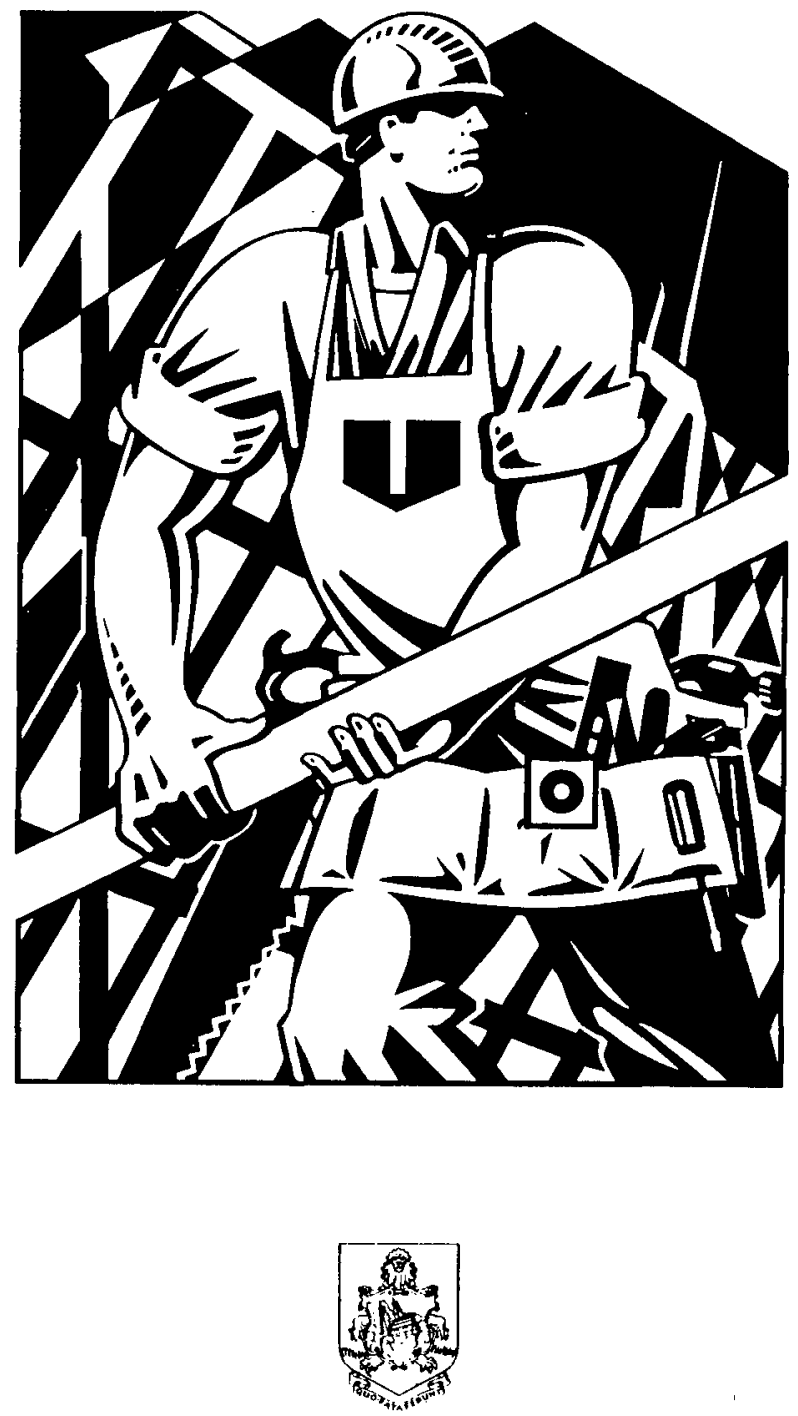

Produced By The DePartme' TF PLANNING 


\section{What is a Building Permit?}

A Building Permit is a licence which grants legal permission to start construction of a building project.

\section{What Construction Projects Need Building Permits?}

Check with the Planning Department for the requirements. Building Permits are typically required for the following:

- New Buildings

- Plumbing systems

- Additions

- Renovations

- Demolitions

- Prefabricated structures

- Docks

- Electrical systems

- HVAC systems (heating. ventilating, air conditioning)

- Misc. residential improvements (fireplace. pools, decks. fences, etc).

- Temporary buildings

- Misc. commercial improvements (parking, health, food handling. etc.)

\section{‡ Mapurpose of Permits}

Permits allow the enforcement of codes which have been adopted as law by Bermuda. No matter what the specific project may be, the enforcement of codes is carried out to protect the public health, safety and welfare. Government, in enforcing the code, is acting to ensure safe construction.

\section{4 sophermits}

Building officials and inspectors use Building Permits as a vital step in their enforcement of codes. You have an investment in the home or business you are about to build or remodel. When that home or business building does not comply with the codes, your investment could be reduced. Applying for a Building Permit notifies the Building Officials that you are constructing or remodeling $a$ hi ilding so they can ensure code compliance.

\section{Why a Building Permit?}

Building Permits provide the means for tuit it officials to protect us by reducing the potentlu. hazards of unsafe construction and thereby ensure the public health, safety and welfare.

The Building process helps us understand what our local laws are. Before any construction or remodeling work begins, application for a permit should be made.

Building Permits provide the means for building officials to inspect construction to ensure that minimum standards are met and appropriate materials are used

\section{The Permit Process}

\section{Visit or Call the Planning Department}

The Building Control Officers will ask "What are you planning to do?" and "Where are you planning to do it?" Then, the Official will explain the requirements (codellaws) for your project. An application for a Building Permit will be given to you at this time. This initial contact will provide the resources and information you will need to make your project a success and avoid potential problems which could cost you time and money.

\section{Submit an Application}

The Permit Application requires information about the construction project. You'll be asked to document WHO will perform the work. WHAT will be done. WHERE the work will be done. WHEN the work will be done. HOW the the work will be done. Sketches, drawings, plans or other documentation of the proposed work will have to be submitled for review.
A fee will be collected at this time. The permit fee helps defray the cost of the time spent in the application process, the review process and on-site

sction process. The fee also gives you access to t. . official's knowledge and experience when and if you have any questions about your construction project. An additional fee for services such as water connection and surveys may be required.

\section{Wait During the Review Process}

The majority of permit applications are processed will little delay. The Building Control Officers will determine if your project is in compliance with construction codes, planning laws and with other regulations.

\section{Receive the Results of the Review Process}

A If compliance with the code, zoning and other applicable regulations is determined, the Application approved and a permit issued.

B If the proposal is not code compliant, your application as submitted, will be denied. If you are $r^{\prime}$ ' sed a Building Permit, you can correct the Code tions or appeal the decision.

\section{Receive a Permit}

The Building Permit is the document granting legal permission to start construction. You must proceed as approved in the Review Process.

Inspections required for your project will be indicated on the permit. You must post the building permit in a window or other prominent place at the construction site, keep a copy of the building plans at the site. and bring any proposed changes to the attention of the Building Official immediately. Changes will require a review and approval in the same manner as the original application. 
APPENDIX O

PHOTO BERMUDA TRADITIONAL ROOF 


\title{
ARCHITECTURE
}

\author{
BERMUDA STYLE
}

BY

David F. Raine

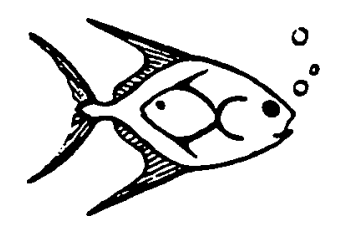

Pompano Publications

BERMUDA - CANADA * ENGLAND 
APPENDIX P

QUOTATIONS FROM ELLEN WHITE/CHURCH FUNDING 
Extravagance in Embellishing and Furnishing

The various religious bodies, re-enforced by the wealth and influence of these baptized wordings, make a still higher bid for popularity and patronage. Splendid churches, embellished in the most extravagant manner, are erected on popular avenues. GC 386

ECONOMY (Plain, Neat, and Perfect in Design)

We have no command from God to erect a building which will compare for richness and splendor with the temple. But we are to build a humble house of worship, plain and simple, neat and perfect in its design.

Then let those who have means look to it that they are as liberal and tasteful in erecting a temple wherein we may worship God as they have been in locating and building and furnishing their own houses. Let them manifest a willingness and a desire to show greater honor to God than to themselves.

Let them build with nicety but not with extravagance. Let the house be built conveniently and thoroughly so that when it presented to God He can accept it and let His Spirit rest upon the worshipers who have an eye single to His glory. Nothing must interfere between God's glory and us; no selfish plans, no selfish schemes, no selfish purposes. There must be an agreement. EV 378

\section{Economy}

In none of our buildings should we seek to make a display, for this would not advance the work. Our economy should testify to our principles. We should employ methods of work that are not transcient. Everything should be done solidly.' GW 433

\section{Loan}

There are some cases, however, in which a young church may not be able at once to bear the whole burden of erecting a house of worship. In these cases, let the brethren in other churches help them. In some cases it may be better to hire some money than not to build. If a man has money, and, after giving what he can, will make a loan, either without interest or at a low rate, it would be right to use the money unt1l the indebtedness can be lifted. If possible, church buildings should be dedicated free to debt.

In our churches the pews should not be rented. The wealthy are not to be honored above the poor. Let no distinction be made. "All ye are brethren." GW 432

\section{Financial Help From the Outside}

We all need to be wide awake, that, as the way opens, we may advance the work in the large cities. We are far behind in following the instruction to enter these citles memorials for God. Step by step we are to lead souls into the full light of truth. We are to continue working until a church is organized, and a humble house of worship built. I am greatly encouraged to believe that many persons not of our faith will help considerably by their means. The light given me is that in many places, especially in the great cities of America, help will be given by such persons. EV 379 
Debt

The house where God meets with His people will be dear and sacred to every one of His loyal children. It will not be left crippled with debt. To allow such a thing would appear almost like a denial of your faith. You will be ready to make a great personal sacrifice if only you may have a house free from debt, where God can meet with and bless His people. GW 434

Every debt upon every house of worship among us may be paid if the members of the church will plan wisely and put forth earnest, zealous effort to cancel the debt. And in every case where a debt is lifted, let there be a service of thanksgiving, which shall be as a re-dedication to God of His house.

6TC 100-104

Whenever it is possible, let our church buildings be dedicated to God free of debt. When a church is raised up, let the members arise and build. Under the direction of a minister who is guided by the advice of his fellow-ministers, let the newly converted ones work with their own hands, saying, "We need a meeting-house, and we must have it." God calls upon His people to make cheerful, united efforts in His cause. Let this be done, and soon will be heard the voice of thanksgiving, "See what the Lord hath wrought!" GW 432

The lax way which some churches have of 1ncurring debts and keeping in debts, was presented before me. In some cases a continual debt is upon the house of God. There is a continual interest to be paid. These things should not and need not be. If there is that wisdom and tact and zeal manifested for the Master which God requires, there will be a change in these things. The debts will be lifted. God calls for offerings from those who can give, and even the poorer members can do their little. Self-denial will enable all to do something. Both old and young, parents and children, are to show their faith by their works. Let the necessity that each act a part be most strenuousiy impressed upon the members of the church. Let every one do his best. When there is will to do, God will open the way. He does not design that His cause shall be trammeled with debt.

God calls for self-sacrifice. This will bring not only financial but spiritual prosperity. Self-denial and self-sacrifice will work wonders in advancing the spirituality of the church. GW 433 
God Wants His People to Use Their Means to Help

There should be no delay. The cause of God demands your assistance. We ask you, as the Lord's stewards, to put His means into circulation, to provide facilities by which many will have the opportunity of learning what is truth.

The temptation may come to you to invest your money in land. Perhaps your friends will advise you to do this. But is there not a better way of investing your means? Have you not been bought with a price? Has not your money been entrusted to you to be traded upon for Him? Can you not see that He wants you to use your means in helping to build meeting-houses, in helping to establish sanitariums, where the sick shall receive physical and spiritual healing, and in helping to start schools, in which the youth shall be trained for service, that workers may be sent to all parts of the world? CS 44-45

\section{Self-Denial and The Church Mortgage}

The test question for every Christian to ask himself is, Have $I$, in my innermost soul, a love for Jesus? Do I love His tabernacle?... Is my love for God and my Redeemer strong enough to lead me to deny self? When temptations come to indulge in pleasure and selfish enjoyment, shall I not say, No, I will not spend one shilling or even sixpence for my own gratification while the house of God is under mortgage, or bearing the pressure of debt? CS 260 
APPENDIX Q

ADMINISTRATIVE OFFICE SPACE 


\section{$\underline{\text { Administrative Objectives }}$}

The spiritual welfare of the responding community is of prime importance. All the facilities and personnel are there to provide an atmosphere for spiritual growth to take place. The administrative service provides the resource material and leadership to aid in this goal. In order to do this the resources and personnel of administration must seek to grow to implement the church program. It must encourage, stimulate, experiment with, and evaluate the present situation in order to fulfill its ultimate reason for existing. Coordinated church planning is the key to provide opportunity for growth. Administration must guide a movement toward developing a flexible church program that allows for individual ministries within the church.

Because the Pastor has been given the major responsibility and authority to oversee the local church he is to be first among equals. His role is that of serving as the chief spiritual leader of the local church. He is the principle planner for official services and religious worship activities. He is the main representative of the congregation to its membership and community. He is also the enabler of lay leadership and the facilitator of outreach involvement in the local church. Ultimately he oversees the administrative process of the local church, united with the guidance and cooperation with the church membership.

\section{Discernable Trends}

As a direct result of research, changes are being brought about in connection with the structure of church administration and its operating procedures. Through the 1960 's, two 
countervailing trends occurred in most major denominations. Ministers were encouraged to become "enablers" and "enhances" of the skills of lay persons at the same time that organizations structures were becoming more centralized and demanding. Part of the thrust of recent changes in the major denominations has been the redistribution of decision-making powers. Local congregations, especially those considered less than self-supporting or "full-range" churches, have been asked to work in organizational settings not of their making, to their liking, or suitable to their needs. ${ }^{1}$

In the SDA Church the trend now is to recognize the abilities that are present in the local church membership. Ideally the local church, working in relation with the pastor, prepare church programs to meet their capabilities and the needs of their community. Hence. there is a trend to prepare members for ministry in specific areas and in specific ways. Self initiated research and study for the purpose of revision and implementation of new ideas and methods are now required for church administration. Not only is the pastor the spiritual leader he is also a resource person. The other branches of the denomination are also seen in this light.

The administrative area is no longer just a couple of rooms only for the pastor and/or associate pastor and a secretary, but is a leadership center and a center for member and church officer services, as well as a center for business management. Administrative facilities are units of control, communication, and coordination and should normally occupy a controlling and readily accessible position within a building complex. For that reason, on entry of the church grounds, visitors should, by its mere location, meet up first with indications of the administrative center; high visibility and easy public access are paramount.

\section{$\underline{\text { Activities }}$}

The general type of activities which will occur in the administrative center will include 
reception; general 'office work, including record-keeping, bookkeeping, personnel control, clerical and stenographic work; buying; mimeographing; maintenance supervision; conferences with members, visitors; and storage of office materials, supplies, equipment and records. In general, these activities can be divided into six main ones as follows

1. General oversight and leadership. This is to be done by the pastor in coordinating activities and programs as delegated.

2. Reception. Any visitors to the church will need to be received and welcomed so that they can be directed to whatever persons or place they need to be.

3. General office work. The general office work should include typing, duplication, filing and postal services. It also includes having and controlling the various communication avenues (e.g. telephone, intercom within the building.) Preparing and disseminating information about the church is another function carried on in this area.

4. Bookkeeping. Bookkeeping activities include accounting, purchasing, control of inventory, and supplies.

5. Church Administration. While the pastor is the church leader the direction of the church program is delegated to the officers who in turn direct and work directly with members.

6. Research and Counseling. The preparation of sermons and related work is to be done here. Studying, planning and 
can be divided into six main ones as follows:

1. General oversight and leadership. This is to be done by the pastor in coordinating activities and programs as delegated.

2. Reception. Any visitors to the church will need to be received and welcomed so that they can be directed to whatever persons or place they need to be.

3. General office work. The general office work should include typing, duplication, filing and postal services. It also includes having and controlling the various communication avenues (e.g. telephone, intercom within the building.) Preparing and disseminating information about the church is another function carried on in this area.

4. Bookkeeping. Bookkeeping activities include accounting, purchasing, control of inventory, and supplies.

5. Church Administration. While the pastor is the church leader the direction of the church program is delegated to the officers who in turn direct and work directly with members.

6. Research and Counseling. The preparation of sermons and related work is to be done here. Studying, planning and consultation of visitors as well as related work are included 
in this section.

\section{Administrative}

Administrative personnel to carry out these activities described above are as follows:

1. Pastor

2. Associate Pastor

3. Secretary to the pastors

4. Part-time General Clerk/part-time Bookkeeper

5. Volunteer Help

\section{B. PHYSICAL REQUIREMENTS}

Space Requirements

Administrative Core

One office for Pastor

One office for Associate Pastor

One office for Secretary, Clerk, Bookkeeper,

Reception area

Storeroom

Administrative Suite Restroom - Men's

Administrative Suite Restroom - Women's

Conference Room 300

Area in Square Feet

150 


\section{Description of Spaces}

1. Pastor's Office. The pastor's office should be carpeted. It should have easy access to the church sanctuary, secretary and conference room. This office should contain an outside entrance. This office should receive full acoustical, visual, and thermal treatment. This office should be easily accessible by callers.

Furniture and equipment for the pastor's office should consist of an executive desk, chair, bookshelves, five easy chairs, outside phone, 3 file cabinets, and a clock. The decorations and furnishings should reflect the leadership role of the pastor.

2. Associate Pastor's Office. This office should be carpeted. It should have easy access to the church sanctuary and conference room. This office should contain an outside entrance. It should receive full acoustical, visual, and thermal treatment. This office should be easily accessible by callers.

Furniture and equipment for the associate pastor's office should consist of an executive desk, chair, bookshelves, five easy chairs, outside phone, 3 file cabinets and a clock. The decorations and furnishings should reflect the leadership role of the associate pastor.

3. The reception area and office for secretary, clerk and bookkeeper. This area is the hub of the administrative center and should lead directly to the office of the pastor, assistant pastor and storeroom. It needs to provide work space for three people. This area should be carpeted. This office should receive full acoustical, visual thermal treatment. This area should be easily accessible by callers. The reception area is included here.

Furniture for this office should include two desks and chairs. A minimum of four filing 
cabinets is needed. Five easy chairs are needed and a clock. The decorations and furnishings should reflect the warmth of this responsibility.

4. Vault. This space should be located in close proximity to the pastor's office and the secretaries office. It should have a door with a four hour fire rating, with fire resistant cautions for walls and ceilings.

5. Storeroom. This area should be immediately adjacent to the secretary's office. It should be lined with shelves, including free standing shelving in the center of the room.

6. Administrative suite restrooms. Two restrooms should be provided. These should contain one commode and wash basin each. Each should be adequately ventilated, lighted, thermally and acoustically treated.

7. Conference Room. This room should be carpeted. A large table with chairs for 10 people should be included. A clock should be included.

8. Church Library. This area should be lined with shelves. A counter should be present to write on and 3 easy chairs should be present.

\section{Desired Space Relationship}

The administrative area should be near the main entrance of the church facility. This area should be readily accessible to all areas of the church. 


\begin{tabular}{lcc}
\multicolumn{1}{c}{ STORAGE } & RESTROOMS \\
$\begin{array}{l}\text { ASSOCLATE } \\
\text { PASTOR }\end{array}$ & LIBRARY \\
& RECEPTION & \\
& SECRETARY & \\
CONFERENCE & & \\
ROOM & & PASTOR' $^{\prime}$
\end{tabular}


BIBLIOGRAPHY 


\section{BIBLIOGRAPHY}

Arthur, Gay, Jr., Robert Rhoden, James Smith III, and Lloyd Sturtz. "The Coffer Crunch." Leadership Journal, Winter 1989, 130-138.

Bennis, Warren. On Becoming a Leader. Reading, MA: Addison-Wesley, 1989.

Bermuda Conference of Seventh-day Adventists. Statistical Report Year-End. Hamilton, Bermuda: Bermuda Conference, 1995.

Bermuda Mission of Seventh-day Adventists. Business Session Report. Hamilton, Bermuda: Bermuda Mission, 1959.

- President's Report, Fiftieth Biennial Session of the Bermuda Mission.

Hamilton, Bermuda: Bermuda Mission, 1967.

Briefs for Church Builders: Setting up a Church Parking Lot. Anderson, IN: The Church of God, n.d.

Building Permits: Why and How? Hamilton, Bermuda: Department of Planning, n.d.

Bruggink, Donald, and Carl Droppers. Christ and Architecture. Grand Rapids, MI:

William B. Eerdmans Publishing Company, 1965. Quoted in Robert Carr, "The Arch-liturgical Movement and the Seventh-day Adventist Church." Master's thesis, Michigan State University, 1975. Adventist Heritage Center, James White Library, Andrews University, Berrien Springs, MI.

Carr, Robert. "The Arch-Liturgical Movement and the Seventh-day Adventist

Church." Master's Thesis, Michigan State University, 1975. Adventist Heritage

Center, James White Library, Andrews University, Berrien Springs, MI.

Christ-Janer, Albert, and Mary Foley. Modern Church Architecture. New York:

McGraw-Hill Publishing Company, 1959. Quoted in Robert Carr, "The Archliturgical Movement and the Seventh-day Adventist Church." Master's thesis, Michigan State University, 1975. Adventist Heritage Center, James White Library, Andrews University, Berrien Springs, MI.

"Churches to Be Built." MS 29, 1901. E. G. White Research Center. 
Conklin, Robert. How to Get People to Do Things. New York: Ballantine Books, 1979.

Covey, Stephen. Principle-Centered Leadership. New York: Simon \& Schuster Publishers, 1992.

Davies, John G. "The Influence of Architecture upon Liturgical Change." Studia Liturgica 9 (1973): 230-40.

Davidson, Richard. The Garden of Eden a Sanctuary. Andrews University Theological Seminary, Berrien Springs, MI, paper presented to NAD Presidential Retreat, California, 1996.

DeVille, Jard. The Pastor's Handbook on Interpersonal Relationship. Silver Spring, MD: The Ministerial Association, General Conference of Seventh-day Adventists, 1995.

Doom, James L., quoted in Willmar L. Thorkelson, "Integrated Buildings," Christianity Today, July 6, 1973, 44

Evangelism. Washington, DC: Review and Herald, 1946.

Fletcher, George. Recipe for a Better Church Kitchen. Nashville, TN: n.p., n.d.

Folkenberg, Robert S. Newsletter from the General Conference President. Silver Spring, MD, January 29, 1996.

General Conference of Seventh-day Adventists. Global Mission, 132nd Annual Statistical Report. Silver Spring, MD: Office of Archives and Statistics, 1994.

- Seventh-day Adventist Church Manual. Washington, DC: Review and Herald Publishers, 1986.

- Working Policy of the General Conference of Seventh-day Adventists. Washington, DC: Review and Herald, 1995-1996 edition.

General Conference of Seventh-day Adventists, Ministerial Association. Seventh-day Adventists Ministers Manual. Silver Spring, MD: Ministerial Association, 1992.

General Conference of Seventh-day Adventists, Building Plans Committee. Suggestions to Building Planners. Rev. ed. Silver Spring, MD: General Conference of Seventh-day Adventists, 1991. 
General Conference of Seventh-day Adventists, Communication Department. Images of Mission. Silver Spring, MD: Communication Department of General Conference, 1995.

Haugh, Kenneth C. Antagonists in the Church. Minneapolis: Augsburg Publishing House, 1988.

Henry, Thornton. On This Rock: A Photographic Essay on the Churches of Bermuda. Ontario, Canada: Carter and Carter Publishers, 1993.

Holmes, Raymond C. Sing a New Song. Berrien Springs, MI: Andrews University Press, 1984.

Kouzes, James M., and Barry Z. Posner. The Leadership Challenge. San Francisco: Jossey-Bass Publishers, 1987.

Leas, Speed B. Moving Your Church through Conflict. New York: Alban Institute Publication, 1985.

Lueck, Norman. Property Committee Manual. Philadelphia: Parish Life Press, n.d.

The Lutheran Church--Missouri Synod. Architectural Guide: For Worship and Education. Rev. ed. St. Louis, MO: Commission on Architecture Magazine, 1978.

Lyles, Jean Caffey. "Friendly Spaces, Ecclesiology and the Architect: National Interfaith Conference on Religion and Architecture." Christian Century, September 21, 1997, 807.

Lynn, Edwin C. "Shaker Spaces: The Psychology of Simplicity in Religious Architecture." Your Church, October 1974, 16-17.

Maquire, Robert, and Keith Murray. Modern Churches of the World. New York: E. F. Dutton and Company, 1965.

Maxwell, John C. Developing the Leader Within You. Nashville: Thomas Nelson, 1993.

Met, Don. New Congregations. Westminster Press, 1967. Quoted in Speed Leas, Moving Your Church through Conflict. New York: Alban Institute Publication, 1985.

Olivia, Peter. Supervision for Today's Schools. 4th ed. White Plains, NY: Longman Publishing Group, 1993. 
Peat, Halsey V. Letter to Carlyle C. Simmons, 19 September 1994. In my possession.

Perry, Everett L. Selection of a Church Site. Anderson, IN: Department of Church Building, n.d.

Raine, David F. Architecture, Bermuda Style. Bermuda: Pompano Publishers, 1989.

Santini, Ray. "The Choir Loft." Ministry Magazine 26 (January 1953): 22. Quoted in Robert Carr, "The Arch-liturgical Movement and the Seventh-day Adventist Church." Master's thesis, Michigan State University, 1975. Adventist Heritage Center, James White Library, Andrews University, Berrien Springs, MI.

Schwanda, Tom. "Symbolism at Work: The Gospel According to Architecture." Reformed Review 31 (Spring 1978): 134.

Scotford, John R. When You Build Your Church. New York: Meredith Press, 1968.

Smith, Roslyn P. The Architecture of Bermuda. Bermuda: Smith's Parish, 1985. In my possession.

Smits, Richard A. "The Gospel and Architecture." Christianity Today, April 23, 1976, 19-20.

Sovik, Edward A. Architecture for Worship. Minneapolis: Augsburg, 1973.

Streeter, Edward. Syllabus for CHMN 528 Architecture for Clergy, Andrews University, Berrien Spring, MI, 1981.

The Bermuda Plan 1992. Planning Statement Producing the Department of Planning, June 1992. Hamilton, Bermuda: Bermuda Press, 1992.

Thorkelson, Willmar L. "Integrated Buildings." Christianity Today, July 6, 1973, 44.

Tischler, Nancy M. "Sticks and Stones." Christianity Today, June 7, 1974, 19.

Van Loon, Ralph R. "The Church Building." In Space for Worship, 7. Philadelphia, PA: Lutheran Church Publishers, 1975.

Webb, Garrison. "Wesley's View of Baptism and the Lord's Supper." Ministry Magazine 28 (April 1955), 36. Quoted in Robert Carr, "The Arch-liturgical Movement and the Seventh-day Adventist Church." Master's thesis, Michigan State University, 1975. Adventist Heritage Center, James White Library, Andrews University, Berrien Springs, MI. 
Webber, Robert E. "Church Buildings: Shapes of Worship." Christianity Today, August 7, 1981, 19.

White, Arthur L., to Richard Hawley, 20 October 1971. Q and A File 16-0-2, Ellen G. White Research Center, Andrews University, Berrien Springs, MI. Quoted in Robert Carr, "The Arch-Liturgical Movement and the Seventh-day Adventist church." Master's Thesis, Michigan State University, 1978. Adventist Heritage Center, James White Library, Andrews University, Berrien Springs, MI.

to W. W. Menshausen, 10 April 1964. Q and A File 16-0-1, Ellen G. White Research Center, Andrews University, Berrien Springs, MI. Quoted in Robert Carr, "The Arch-liturgical Movement and the Seventh-day Adventist Church." Master's thesis, Michigan State University, 1975. Adventist Heritage Center, James White Library, Andrews University, Berrien Springs, MI.

White, E. G. "Building a House for God." MS 23, 1886. Ellen G. White Research Center, Andrews University, Berrien Springs, MI.

- Christian Services. Washington, DC: Review and Herald, n.d.

. "Churches to Be Built," MS B29, 1901, Ellen G. White Research Center, Andrews University, Berrien Springs, MI.

. Councils on Stewardship. Takoma Park, Washington, DC: Review and Herald, 1940.

. Evangelism. Washington, DC: Review and Herald, 1946.

- Gospel Workers. Washington, DC: Review and Herald, 1915.

. Great Controversy. Washington, DC: Review and Herald, 1950.

. "Guard Against Unwarranted Expense," MS 23, 1886, E. G. White Research Center, Andrews University, Berrien Springs, MI.

. "Honor the Lord with Thy Substance." Youth's Instructor, 26 August 1897, 266. Quoted in Robert Carr, "The Arch-liturgical Movement and the Seventh-day Adventist Church." Master's thesis, Michigan State University, 1975. Adventist Heritage Center, James White Library, Andrews University, Berrien Springs, MI.

. "The Influence of a House of Worship." General Conference Bulletin, January 27, 28, 1893. E. G. White Research Center, Berrien Springs, MI. 

450 .

"Larger Churches Helping Smaller." Review and Herald, July 21, 1891,

. "Lessons from the Life of Solomon." Review and Herald, 4 January 1906, 7. Quoted in Robert Carr, "The Arch-liturgical Movement and the Seventh-day Adventist Church." Master's thesis, Michigan State University, 1975. Adventist Heritage Center, James White Library, Andrews University, Berrien Springs, MI.

- Testimonies to Ministers and Gospel Workers. Mountain View, CA: Pacific Press, 1962.

- Testimonies to the Church. 9 vols. Mountain View, CA: Pacific Press, 1948.

. Welfare Ministry. Washington, DC: Review and Herald, 1952.

White, James F. Protestant Worship and Church Architecture. New York: Oxford University Press, 1964. Quoted in Robert Carr, "The Archi-liturgical Movement and the Seventh-day Adventist Church." Master's thesis, Michigan State University, 1975. Adventist Heritage Center, James White Library, Andrews University, Berrien Springs, MI.

Wolterstorff, Nicholas. "Expressing Our Convictions-Some Thoughts on Church Building." The Reformed Journal 23, no. 1 (January 1973): 11, 230. 
VITA

PASTOR CARLYLE C. SIMMONS

(Ordained 1978)

\section{ACADEMIC ACHIEVEMENTS:}

Degree

Bachelor of Theology

Master of Divinity

Doctor of Ministry

\begin{tabular}{cc}
\multicolumn{1}{c}{ Institute } & Year \\
West Indies College & 1971 \\
Andrews University & 1974 \\
Andrews University & 1998
\end{tabular}

1971

1974

1998

\section{CHURCHES PASTORED:}

\begin{tabular}{lll}
\multicolumn{1}{r}{ Parish } & Country & Years \\
Hamilton & Bermuda & 1974-July \\
Somerset & Bermuda & $1974-1984$ \\
Midland Heights & Bermuda & $1984-1985$ \\
Hamilton & Bermuda & $1986-1991$ \\
Southampton & Bermuda & $1992-$ Sept.
\end{tabular}

\section{CONEERENCE DEPARTMENTS DIRECTED:}

Bible Teacher

Religious Liberty

Communication

Education Superintendent

Conference Executive Secretary

Conference President
Bermuda Institute

Bermuda Mission

Bermuda Mission

Bermuda Mission

Bermuda Conference

Bermuda Conference
1974-1976

$1975-1980$

$1978-1980$

1979-1986

1986-1992

1992 -

\section{OTHER PROFESSIONAL ACTIVITUES:}

1. Conducted evangelism and preaching services in Bermuda, England, Uganda, Jamaica, United States.

2. Led in constructing two churches, an elementary and administrative school block, renovated a church, and led out constructing a school auditorium and science block, enlarged the Conference office, projects valued over 7 million dollars.

3. Engaged in active soul-winning.

4. As Conference president, has led in organizing one new church and initiated the start of a new branch outreach. 
5. Has led out in radio and television programs for Conference religious outreach.

6. Has served as a Family Court panelist in the government court system since 1995 . 